\title{
EL CAMPAMENTO MESOLÍTICO DEL CABEZO DE LA CRUZ
}

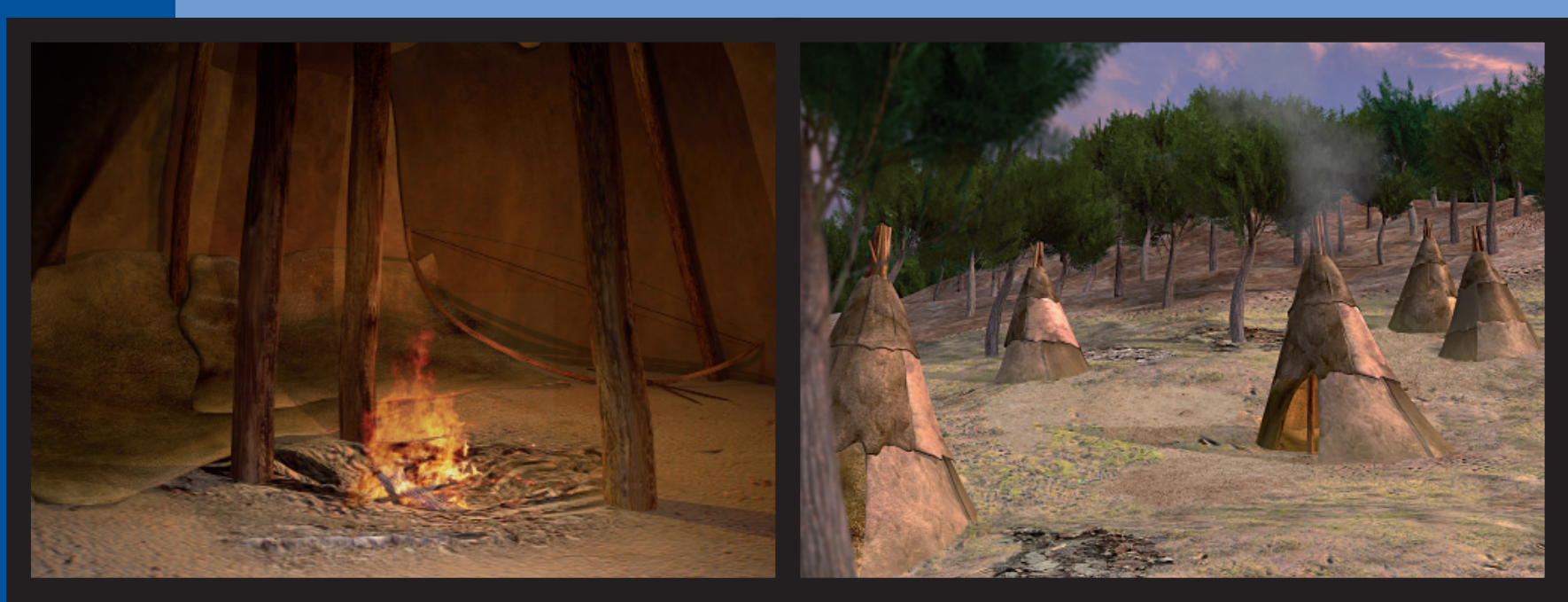

LA MUELA $\cdot$ ZARAGOZA

0
0
0
00
0
0
0
$\frac{0}{2}$
$\frac{1}{2}$
0
$\frac{0}{0}$
$\frac{0}{0}$
$\frac{0}{20}$

José María Rodanés Vicente Jesús Vicente Picazo Millán 

José María Rodanés Vicente y Jesús Vicente Picazo Millán

Carlos Mazo Pérez, Raúl Leorza Álvarez de Arcaya, José Luis Peña Monné, Victoria Rubio Fernández, Víctor Gené González, Ernestina Badal García, María José Iriarte Chiapusso

\section{El campamento mesolítico del Cabezo de la Cruz La Muela. Zaragoza}

Monografías Arqueológicas. Prehistoria, 45

PRENSAS DE LA UNIVERSIDAD DE ZARAGOZA 


\section{RODANÉS VICENTE, José María}

El campamento mesolítico del Cabezo de la Cruz : La Muela : Zaragoza / José María Rodanés Vicente y Jesús Vicente Picazo Millán ; Carlos Mazo Pérez... [et al.] . - Zaragoza :

Prensas de la Universidad de Zaragoza, 2013

144 p. : il. ; $30 \mathrm{~cm}$. - (Monografías arqueológicas. Prehistoria ; 45)

ISBN 978-84-15770-61-9

Cabezo de la Cruz (La Muela, Zaragoza)-Restos arqueológicos prehistóricos

PICAZO MILLÁN, Jesús Vicente

903(460.224)

\section{Monografías Arqueológicas 45 \\ Prehistoria}

\section{Consejo de Redacción de Prehistoria}

Directores: Pilar Utrilla y José M. a Rodanés

Vocales: Teresa Andrés, Carlos Mazo, Lourdes Montes, Carlos Pérez-Arrondo y Jesús V. Picazo

Secretaría Técnica: Rafael Domingo

\section{Consejo Científico Asesor de Prehistoria}

Paul Bhan; Ignacio Barandiarán (Universidad del País Vasco); Concepción Blasco (Universidad Autónoma de Madrid); Gerhard Bosinski (Universidad de Köln); Primitiva Bueno (Universidad de Alcalá de Henares); Margaret Conkey (Universidad de Berkeley); Soledad Corchón (Universidad de Salamanca); Germán Delibes (Universidad de Valladolid); Antonio Faustino Carvalho (Universidad de Faro); Carole Fritz (Universidad de Toulouse Le Mirail); César González-Sainz (Universidad de Cantabria); Miquel Molist (Universidad Autónoma de Barcelona); Lawrence G. Straus (Universidad de Nuevo México); Juan Vicent (Instituto de Historia, CSIC); Valentín Villaverde (Universidad de Valencia)

\section{Consejo de Redacción de Arqueología}

Director: Manuel Martín-Bueno

Vocales: Almudena Domínguez, José Antonio Hernández-Vera, Elena Maestro, Ángeles Magallón, Manuel Medrano, Carlos Sáenz y Paula Uribe

Secretaría Técnica: Carlos Sáenz

\section{Consejo Científico Asesor de Arqueología}

José d'Encarnaçao (Universidad de Coimbra); Angela Donati (Universidad de Bolonia); Piero Gianfrotta (Universidad de la Tuscia, Viterbo); Josep M. ${ }^{a}$ Gurt (Universidad de Barcelona); José Luis Jiménez (Universidad de Valencia); Jesús Liz (Universidad de Salamanca); Milagros Navarro (Instituto Ausonius, Universidad de Burdeos); Jean Michel Roddaz (Instituto Ausonius, Universidad de Burdeos); Desiderio Vaquerizo (Universidad de Córdoba)

Intercambios: Teresa Artigas (tartigas@unizar.es)

Investigación financiada con cargo a los proyectos HUM2005-06512 y HAR2009-13866

(c) Los autores

(c) Departamento de Ciencias de la Antigüedad. Universidad de Zaragoza

(C) De la presente edición, Prensas de la Universidad de Zaragoza

$$
\text { 1. }{ }^{a} \text { edición, } 2013
$$

Impreso en España

Imprime: Servicio de Publicaciones. Universidad de Zaragoza

D.L.: Z 1061-2013 


\section{ÍNDICE}

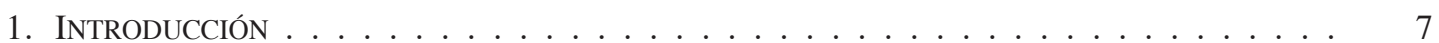

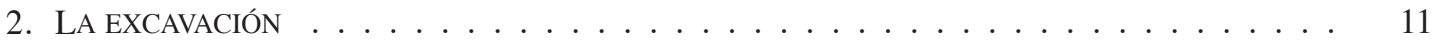

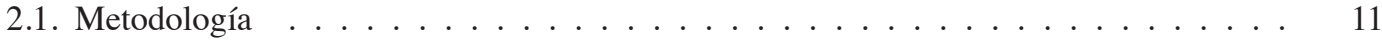

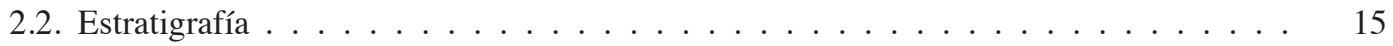

2.2.1. Unidades superiores . . . . . . . . . . . . . . . . . 15

2.2.2. Unidades correspondientes a las fases de ocupación mesolítica. . . . . . . . . 16

2.2.3. Otras unidades fuera de la cabaña . . . . . . . . . . . . . . . . . . . 17

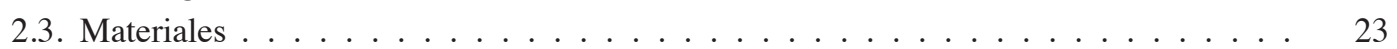

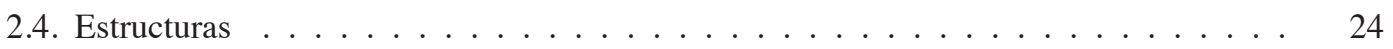

2.4.1. Dispersión de materiales . . . . . . . . . . . . . . . . . . 24

2.5. Dataciones absolutas . . . . . . . . . . . . . . . . . 28

3. ESTUDIO DE MATERIALES . . . . . . . . . . . . . . . . . . . . . . . 31

3.1. Análisis tecno-tipológico y funcional de la industria lítica. Carlos Mazo Pérez . . . . . 31

3.1.1. Sobre tecnología y tipología . . . . . . . . . . . . . . . . . 31

3.1.2. Análisis funcional . . . . . . . . . . . . . . . . . . . . 33

3.1.3. Conclusiones . . . . . . . . . . . . . . . . . . 41

3.2. Estudio de las materias primas líticas. Raúl Leorza Álvarez de Arcaya . . . . . . . . . 43

3.2.1. Prospecciones e identificación de materias primas . . . . . . . . . . . . . 44

3.2.2. Las MP del yacimiento arqueológico . . . . . . . . . . . . . . 57

3.2.3. Consideraciones finales . . . . . . . . . . . . . . . . . . 69

4. El ECosistema . . . . . . . . . . . . . . . . . . . . . . . . . . . . . 75

4.1. Estudio geoarqueológico. José Luis Peña Monné, Virginia Rubio Fernández y Víctor Gené González . . . . . . . . . . . . . . . . . . . . . . . . . . . . . . 75

4.1.1. El contexto geológico y geomorfológico . . . . . . . . . . . . . . . 75

4.1.2. La morfología del yacimiento . . . . . . . . . . . . . . . . . . . . 79

4.1.3. Conclusiones generales e interpretación evolutiva . . . . . . . . . . 81

4.2. Los usos de los vegetales leñosos en el Cabezo de la Cruz (La Muela, Zaragoza) durante la ocupación mesolítica. Ernestina Badal García . . . . . . . . . . . . . . . . . . 83

4.2.1. Introducción, biogeografía y arqueología . . . . . . . . . . . . . . 83

4.2.2. Métodos y materiales . . . . . . . . . . . . . . . . . . . . 83

4.2.3. Carbón y radiocarbono . . . . . . . . . . . . . . . . . . . . 85

4.2.4. Flora . . . . . . . . . . . . . . . . . . . . . 86

4.2.5. Resultados antracológicos . . . . . . . . . . . . . . . . . . 92

4.2.6. El pino carrasco: ¿Pionero y clímax? . . . . . . . . . . . . . . . . . . . 94

4.3. El reflejo del paisaje vegetal del Holoceno medio en el VIII milenio BP en el yacimiento arqueológico del Cabezo de la Cruz (La Muela, Zaragoza) y su entorno. M. ${ }^{a}$ José Iriarte Chiapusso . . . . . . . . . . . . . . . . . . . . . . . 100 
4.3.1. Introducción . . . . . . . . . . . . . . . . . . . 100

4.3.2. Metodología del análisis polínico . . . . . . . . . . . . . . . . . . . . 100

4.3.3. El registro polínico del Cabezo de la Cruz . . . . . . . . . . . . . . . . . 102

4.3.4. El VIII milenio BP en Aragón y su contextualización con el registro del Cabezo de la Cruz . . . . . . . . . . . . . . . . . . . . . . . . . 104

5. El CAMPAMENTO del CABEZO DE la CRUZ EN El CONTEXTO CRONOLÓGiCO Y CULTURAL DE LA MARGEN DERECHA DEL VALLE MEDIO DEL EBRO . . . . . . . . . . . . . . . 109

5.1. Industria lítica . . . . . . . . . . . . . . . . . . . . . . 109

5.1.1. Tipología y evolución de los complejos industriales . . . . . . . . . . . . 109

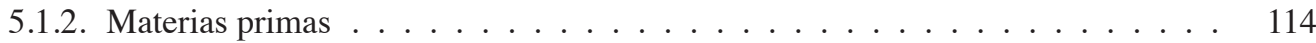

5.2. Adornos: C. rustica . . . . . . . . . . . . . . . . . . . . . 116

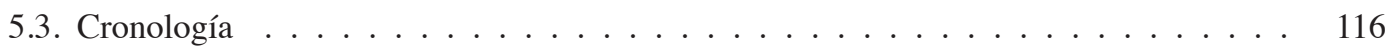

5.4. Ecosistema . . . . . . . . . . . . . . . . . . . . 118

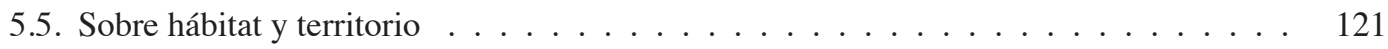

5.5.1. Hábitat . . . . . . . . . . . . . . . . . . . . . . . . . . . . . . . . . . . . .

5.5.1.1. Estructuras . . . . . . . . . . . . . . . . . 124

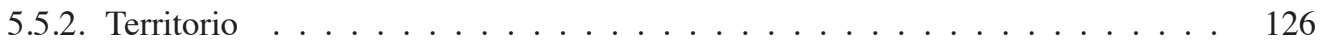

5.5.2.1. Visibilidad . . . . . . . . . . . . . . . . . . . 134

5.5.2.2. Hipótesis sobre la dinámica de poblamiento . . . . . . . . . . . . 138

5.5.2.3 Sobre demografía . . . . . . . . . . . . . . . . . . . 139 


\section{Introducción}

El Cabezo de la Cruz está ubicado en uno de los cerros modelados sobre materiales arcillosos que limitan la vega del río Huerva por su margen izquierda, en el término municipal de La Muela (fig. 1). El poblado ocupa la parte alta (coordenadas UTM 30661186 4595551, 428 m s.n.m.) y laderas del cerro, sobre una superficie aproximada de unos $13000 \mathrm{~m}^{2}$ (figs. 2 y 3). Una descripción más exhaustiva y contextualizada a nivel geológico y geoarqueológico se puede consultar en el capítulo redactado por Peña, Rubio y Gené en esta misma monografía y en la Memoria dedicada a los poblados del Bronce Final y Primera Edad del Hierro (Picazo y Rodanés 2009).
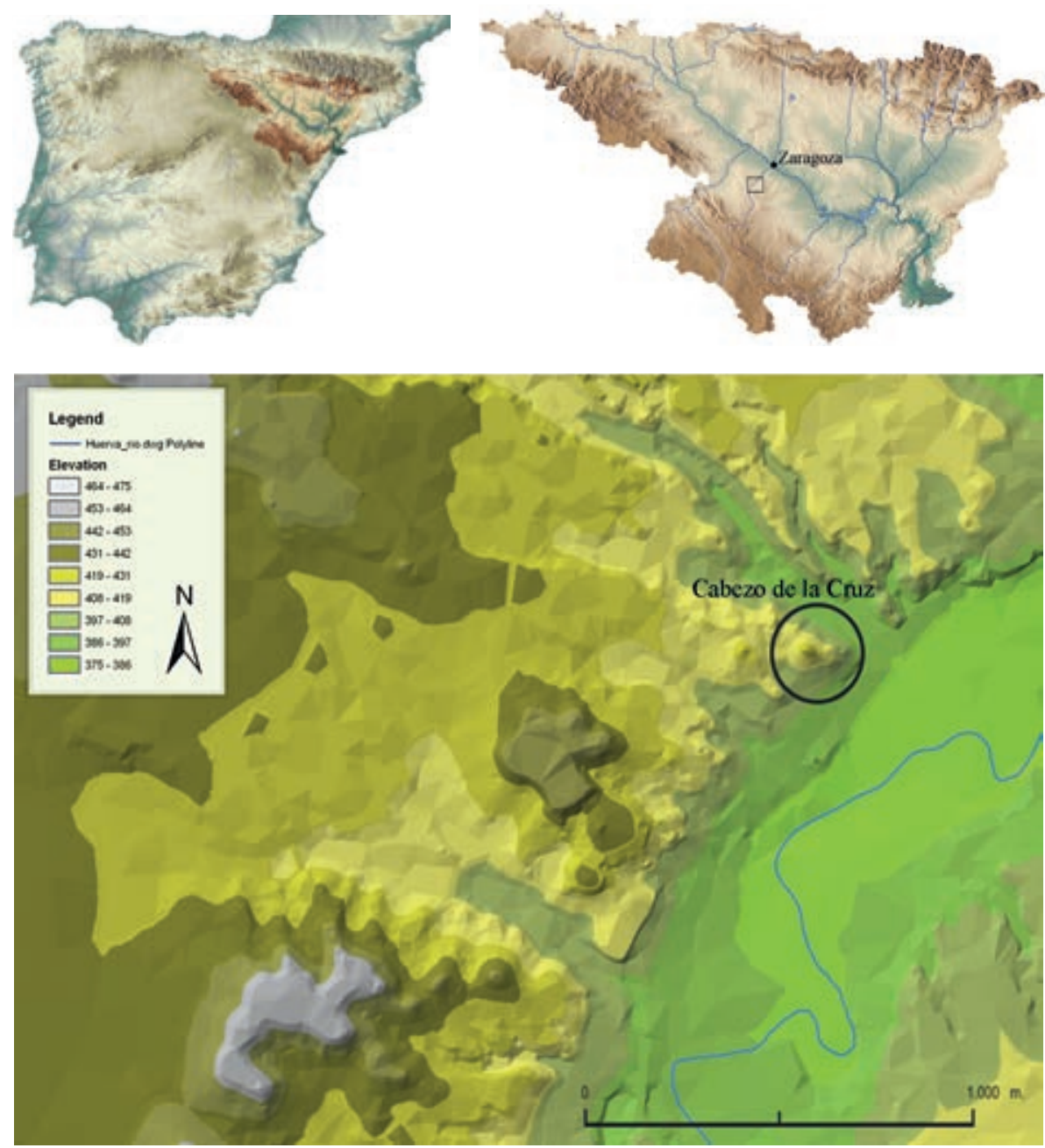

Figura 1. Situación del Cabezo de la Cruz. 


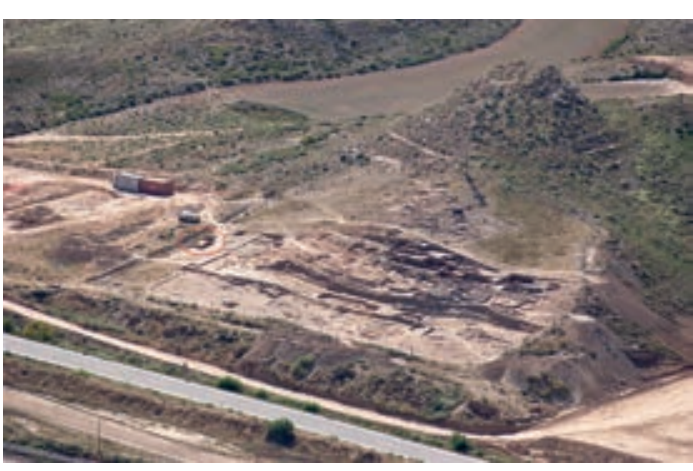

Figura 2. Vista aérea del yacimiento y situación del campamento mesolítico.

La existencia de restos arqueológicos en el Cabezo de la Cruz era conocida desde antiguo por los dueños del terreno, la familia Ortillés, quienes daban un uso cinegético al solar. En 1969 fue publicada en la prensa local una escueta noticia sobre la abundante presencia de restos arqueológicos, siendo conocido también el lugar como «El Sillón».

Para la comunidad científica fue descubierto por J. Fanlo en 1975, hecho que propició una primera publicación (Burillo y Fanlo 1979), recogida con posterioridad en diferentes síntesis (Burillo 1980, 43-45; Ruiz Zapatero 1985, 536-539). El yacimiento cayó en el olvido y fue objeto de suce-

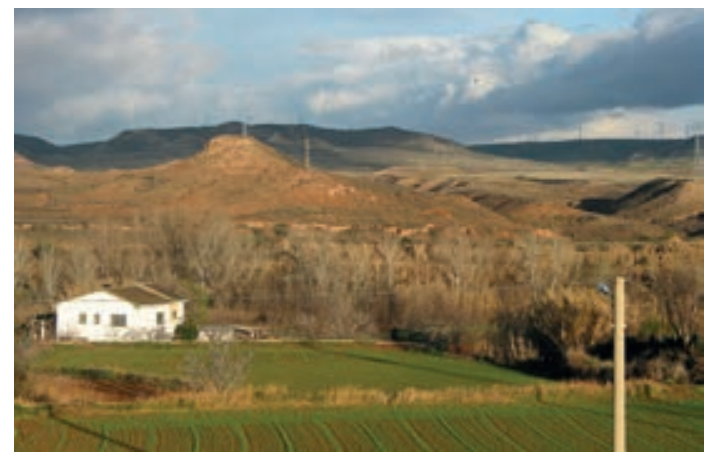

Figura 3. Vista del Cabezo desde la margen derecha del río Huerva.

sivos expolios. Habrán de transcurrir dos décadas hasta que diferentes actuaciones de la Administración local y autonómica se ocupen de los restos del Cabezo.

Buena parte de los trabajos realizados se ha plasmado en informes inéditos que responden a encargos de la Administración y que podemos dividir en dos tipos, según la intervención efectuada: aquellos que se limitan a prospecciones superficiales y delimitación de restos y aquellos que, por el contrario, implican una excavación de mayor o menor extensión y que tienen lugar a partir de 2002.

\begin{tabular}{|l|l|l|}
\hline Actuación & Dirección & Año \\
\hline Descubrimiento y estudio restos superficiales & Burillo y Fanlo & $1975 / 1979$ \\
Prospección informe previo trazado autovía & M.A. García Valero & 1998 \\
Delimitación del yacimiento. PGOU La Muela & Delgado Ceamanos / Del Real & 2002 \\
$1 .^{\text {a }}$ excavación. Ayto. de La Muela & E. Gutiérrez Dohijo & Oct.-nov. 2002 \\
2. ${ }^{\text {a }}$ excavación. Trazado autovía. M. ${ }^{\circ}$ Fomento & Viladés / González (APC) & 2003 \\
$3 .^{a}$ excavación. Trazado autovía. M. ${ }^{\circ}$ Fomento/DGA & Rodanés / Picazo & Feb.-ag. 2004 \\
\hline
\end{tabular}

Principales actuaciones realizadas en el Cabezo de la Cruz.

En 2004, la Dirección General de Patrimonio Cultural del Gobierno de Aragón nos encargó la dirección facultativa de las excavaciones. Con ello se pretendía desarrollar una intervención con criterios de calidad, centrada en la zona afectada por el trazado de la autovía. Para ello se configuró un amplio equipo interdisciplinar que permitió desarrollar un programa de investigación, en principio, orientado a su aplicación a un asentamiento de grandes dimensiones y con estructuras constructivas evidentes, pero que demostró su eficacia en la identificación y posterior estudio de una serie de estructuras que respondían a una primera ocupación del cerro, concretamente al campamento mesolítico objeto de este estudio.

A lo largo de estos años, en especial desde los recientes trabajos de campo, el yacimiento ha sido objeto de diversas publicaciones que se relacionan en el apartado bibliográfico y que se incluyen en los proyectos HUM2005-06512 En el camino de la complejidad. El desarrollo de las comunidades agrarias en el valle del Ebro entre el final del Neolítico y la Primera Edad del Hierro y HAR2009-13866 En el camino 
de la complejidad. Las Comunidades de la Edad del Bronce y Primera Edad del Hierro en el valle del Ebro.

Las referencias son de distinta índole, desde los requeridos avances preliminares de la excavación (Rodanés y Picazo 2004 y 2005) previos a la memoria definitiva en la que se recoge el estudio interdisciplinar sobre las fases del Bronce Final y Primera Edad del Hierro (Picazo y Rodanés 2009), cuyo antecedente inmediato fue la exposición dedicada a estas mismas etapas (Rodanés y Picazo 2006), hasta estudios arqueométricos concretos (Badal et al. 2009; Lapuente et al. 2009) u otros que destacan aspectos culturales o socioeconómicos de las diferentes fases (Rodanés y Picazo 2010; Rodanés, Picazo y Peña 2011). En relación con el Mesolítico nos sirven de referente las comunicaciones a diferentes congresos (Picazo y Rodanés 2008; Rodanés y Picazo 2010; Rodanés et al. 2010).

En definitiva, con esta memoria, en la que abordamos de forma monográfica la ocupación mesolítica, pretendemos completar las investigaciones iniciadas en 2004, cuyos precedentes ya hemos comentado.

\section{BIBLIOGRAFÍA}

BADAl, E., CARrión, Y., RodAnÉs, J.M. a y PICAZO, J.V. 2009: «El uso de los vegetales durante la Edad del Hierro en el Cabezo de la Cruz». VIII Congreso Ibérico de Arqueometría. Teruel, octubre 2009.

Burillo Mozota, F. 1980: El valle medio del Ebro en Época Ibérica. Contribución a su estudio en los ríos Huerva y Jiloca Medio. Institución Fernando el Católico. Zaragoza.

BURILLO, F. y FANLO, J. 1979: «El yacimiento del Cabezo de La Cruz (La Muela, Zaragoza)». Caesaraugusta, 47-48: 39-95.

LAPUENTE, P., Picazo, J.V., RodAnÉS, J.M., FANLO, J. e IGEA, J. 2009: «Estudio petrográfico de la producción cerámica modelada a mano del Cabezo de la Cruz, La Muela, Zaragoza (Primera Edad del Hierro)». VIII Congreso Ibérico de Arqueometría, Teruel, octubre 2009.
PICAZO, J.V. y RodAnÉS, J.M. 2008: «Talleres de sílex, poblados y aldeas. Una cabaña mesolítica en el Cabezo de la Cruz (La Muela, Zaragoza)». En Hernández, M.S., Soler, A. y López, J.A. (coords.): IV Congreso del Neolítico Peninsular. Alicante, 137-142.

-, (eds.) 2009: Los poblados del Bronce Final y Primera Edad del Hierro. Cabezo de la Cruz. La Muela, Zaragoza. 496 p. Gobierno de Aragón. Zaragoza.

RodAnÉS, J.M. y PiCAZO, J.V. 2004: «El Cabezo de la Cruz (La Muela, Zaragoza). Excavaciones febrero-agosto de 2004», Kausis, 2: 55-63.

—, 2005: «Excavaciones arqueológicas en el Cabezo de la Cruz (La Muela, Zaragoza). Campaña 2004». Saldvie, 5: 295-320.

-, 2006: Caminos para el futuro, ventanas hacia el pasado. El Cabezo de la Cruz, una comunidad agraria de la Edad del Hierro en el valle del Ebro. Gobierno de Aragón. Diputación Provincial de Zaragoza y Ministerio de Fomento. Zaragoza.

—, 2009: «La Cabaña Mesolítica del Cabezo de la Cruz (La Muela, Zaragoza)». En Utrilla, P. y Montes, L. (eds.): El Mesolítico Geométrico en la Península Ibérica, Monografías Arqueológicas 44, Universidad de Zaragoza: 327-341.

—, 2010: «Aproximación a la demografía de la ocupación de la Primera Edad del Hierro del Cabezo de la Cruz (La Muela, Zaragoza): Fases II y III». Arqueología Espacial, 28: 209-225.

RodAnÉS, J.M., PICAZO, J.V. y PEÑA, J.L. 2011: «El foso defensivo de la Primera Edad del Hierro del Cabezo de la Cruz (La Muela, Zaragoza)». Revista d'Arqueologia de Ponent, 21: 211-219.

Rodanés, J.M., Picazo, J.V., Bea, M., Mazo, C., LeOrZa, R., BadAl, E., Iriarte, M.J., PeÑA, J.L., Rubio, V., GenÉ, V. y GigA, G. 2010: «The Mesolithic hut of Cabezo de la Cruz (La Muela, Zaragoza, Spain)». MESO 2010. Eight International Conference on the Mesolithic in Europe. Santander, septiembre 2010. Póster.

Ruiz ZAPATERo, G. 1985: Los Campos de Urnas del NE de la Península Ibérica. Universidad Complutense. Madrid. 



\section{La excavación}

La intervención general se desarrolló entre los meses de febrero y agosto de 2004, si bien el tiempo de excavación se redujo a unos 5 meses, sobre una superficie aproximada de unos $13000 \mathrm{~m}^{2}$. Entre los días 10 y 11 del mes de junio, en los trabajos de la ladera SO, cuadros 41D-E y 43F, se produjo el hallazgo de los primeros restos que documentaban la existencia de niveles anteriores al Bronce Final. Durante 15 (entre el 10 y el 30 de junio) días se exhumaron las UE correspondientes a esta ocupación que por los materiales se consideró desde un primer momento como perteneciente al Epipaleolítico/Mesolítico, adscripción posteriormente confirmada por las dataciones absolutas.

\subsection{METODOLOGÍA}

En los trabajos de campo se han combinado sondeos en profundidad al inicio y final de la actuación con el fin de contar con estratigrafías claras que proporcionasen una visión diacrónica; y excavación en área o en extensión. El procedimiento ha permitido documentar la ocupación mesolítica.

Sobre la zona de intervención se superpuso una cuadrícula GPS diferencial en tiempo real (fig. 1). Asumimos un pequeño error $(c .2-3 \mathrm{~cm})$ en la delimitación de los cuadros, pero simplificamos los trabajos de cuadriculado sobre el terreno y evitamos las desviaciones que suelen producirse a la hora de proyectar la cuadrícula mediante cintas métricas, especialmente trabajando sobre grandes superficies y en ladera.

- El control estratigráfico se ha llevado mediante el método Harris. La numeración de las unidades estratigráficas ha sido correlativa, comenzando por el n. ${ }^{\circ} 1000$, para diferenciar esta serie de la utilizada en actuaciones anteriores.

- Se efectuó un inventario general de las unidades (fichero Excel), integrándose en una base

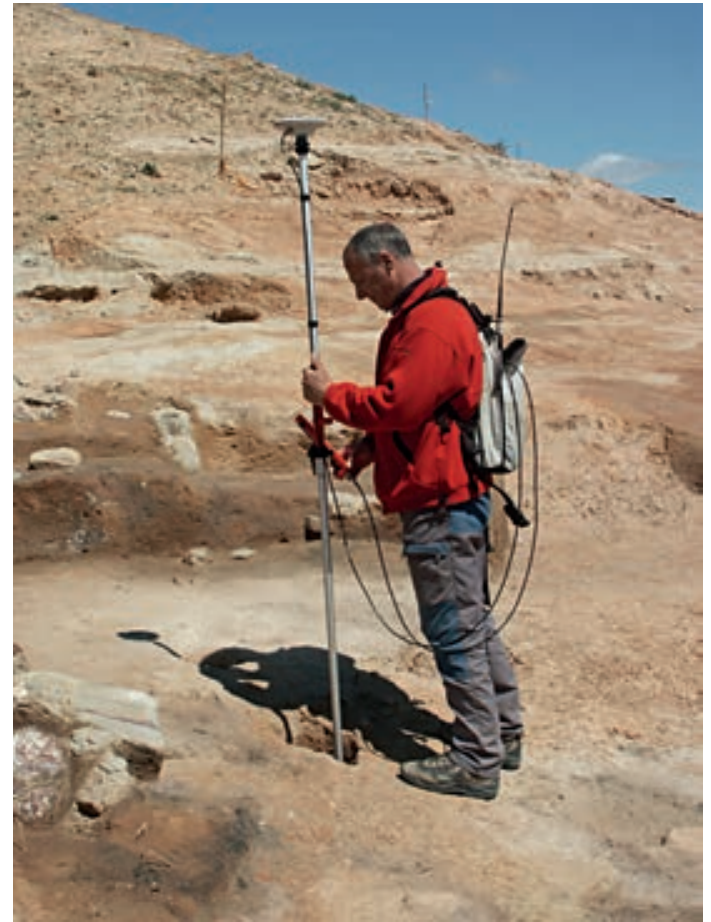

Figura 1. Toma de referencias con GPS diferencial.

de datos electrónica gestionada bajo el programa File Maker Pro, configurando un fichero para sedimentos y otro para estructuras e interfacies.

- La fichas descriptivas se complementan con el registro tridimensional $(x, y, z)$ en coordenadas UTM de cada unidad estratigráfica, tanto sedimentos como interfacies y estructuras. Una vez delimitada la extensión de una unidad se procede a registrar su perímetro (en muchos casos superior e inferior) con el apoyo de una estación total o GPS diferencial. A partir de los puntos tomados se genera la planimetría de las unidades sedimentarias y estructuras con AUTOCAD. El dibujo de las estructuras o de 
las dispersiones de materiales se ha completado a partir de fotografías verticales georreferenciadas (fig. 2).

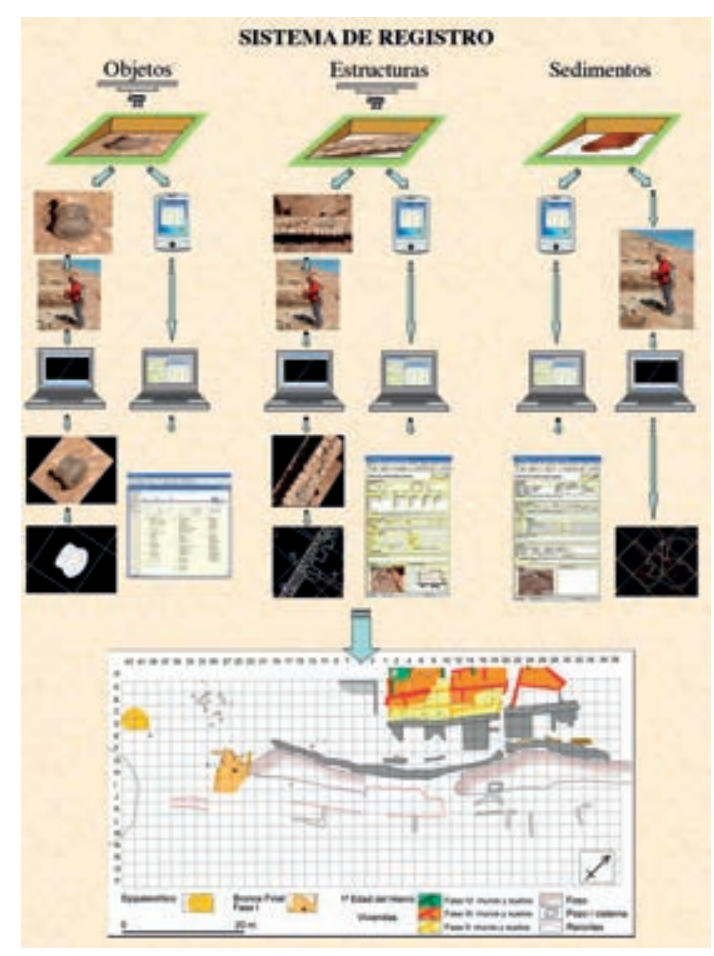

Figura 2. Sistema de registro.

- El sistema de documentación gráfico se ha basado en la realización de fotografías digitales, tanto verticales como oblicuas, con toma de 4 puntos de control con GPS o estación total, georreferenciación de las imágenes con programas Erdas o ArcGis e inserción dentro de los planos generales y dibujo de las estructuras. La documentación fotográfica se completó con un vuelo realizado el 13 de junio de 2005 y con la filmación en video de estructuras, derrumbes y hallazgos en diversos momentos del proceso de excavación.

Los materiales muebles, incluyendo restos orgánicos para datación y diagnóstico, se han recuperado por UE y unidades de cuadrícula, pero aquellos elementos con entidad (muestras de carbón o sedimentos, o materiales significativos in situ...) se han registrado en su posición exacta $(x, y, z)$. Para ello se ha seguido el siguiente procedimiento:

- Una vez localizado un elemento se asigna un número (identificador) que lo acompaña en cualquier documento.
- Con GPS o estación se toman sus coordenadas y unos códigos elementales para su clasificación. La descripción y datos relativos a posición se completan en una agenda electrónica, en un fichero (File Maker Pro) destinado a hallazgos.

- Los puntos se vuelcan en el correspondiente archivo de AUTOCAD donde se van actualizando los hallazgos y generando la correspondiente planimetría. Las fichas de la agenda se integran en una base de datos para su inclusión posterior en el Inventario General.

- La documentación se completa con fotografías digitales en vertical que recogen la dispersión de los materiales in situ. Se toman las coordenadas de 4 puntos de control. Se procede a georreferenciar las imágenes, se insertan en un programa de diseño gráfico (Autocad) y, por último, se lleva a cabo el dibujo de dispersión que se integra en la planimetría general.

La recuperación del material se ha completado con revisión de las tierras extraídas de depósitos masivos y cribado en cedazos de $0,5 \mathrm{~cm}$ de malla de los sedimentos de zonas especialmente significativas.

Los sedimentos se han sometido a un muestreo para flotación. Toma de muestras de tierra de forma sistemática sobre los suelos de viviendas, muestreo en otros depósitos, especialmente basureros, y recuperación integral del contenido existente en el interior de cubículos o dependencias que puedan tener un especial significado funcional. Para procesar estos sedimentos se instaló un sistema de flotación en el propio yacimiento que facilitara lavado de tierras y la recuperación de restos orgánicos. El volumen total de tierras sometido a flotación fue de unos 40001.

El proceso de lavado, sigla e inventario se inició durante la campaña de excavación y posteriormente se completó con dos campañas. Los criterios se ajustaron a lo dispuesto por el Mueso de Zaragoza y para el inventario se ha construido un fichero en Excel con una serie de campos que recogen los datos fundamentales de identificación, posición y descripción.

Nuestro objetivo desde el primer momento fue contar con un procedimiento que nos permitiera ubicar cualquier elemento arqueológico en el espacio y apareciera georreferenciado en coordena- 
das UTM y en cotas sobre el nivel del mar. De esta manera cualquier resto o estructura podía situarse en la cartografía correspondiente integrándose como un rasgo más de la misma con absoluta precisión. Para ello contamos con los servicios de Rafael Larma, técnico especializado en trabajos topográficos, quien desarrolló el procedimiento a partir de la utilización sistemática de un equipo GPS diferencial, ${ }^{1}$ trabajando en tiempo real. Este equipo, integrado por dos unidades geodésicas de la marca Leica (GPS500), se complementó con una estación total para aquellas estructuras o partes de ellas cuyos puntos no eran accesibles para la antena del GPS. ${ }^{2}$ Para mejorar la precisión en la toma de datos, antes de comenzar los trabajos de excavación, se efectuaron medidas de posición en varios vértices geodésicos y se procedió a calcular los parámetros para llevar a cabo la transformación de coordenadas desde el sistema de referencia GPS (World Geodetic System 1984 -WGS84-) al sistema de coordenadas locales habitual en la cartografía peninsular (proyección UTM, European Datum 1950 -ED50-, Elipsoi-

1 El procedimiento empleado, llamado GPS con corrección diferencial o DGPS, sirve para eliminar o reducir muchos de los errores que afectan la medición de distancia a los satélites. En este sistema se usan dos equipos, el receptor de referencia o fijo y el receptor móvil. Una antena del receptor de referencia es montada en un punto medido previamente con coordenadas conocidas. Al receptor que se coloca en este punto se le conoce como Receptor de Referencia o Estación Base. Debido a que el receptor se encuentra en un punto conocido, el receptor de la referencia puede estimar en forma muy precisa la distancia a cada uno de los satélites. De esta forma, este receptor puede determinar muy fácilmente cuál es la diferencia entre la posición calculada y la posición medida. Estas diferencias son conocidas como correcciones. Generalmente, el receptor de la referencia está conectado a un radio enlace de datos, el cual se utiliza para transmitir las correcciones. El receptor móvil también cuenta con un radio enlace para recibir las correcciones transmitidas por el receptor de referencia. El receptor móvil, por su parte, calcula las distancias hacia los satélites, luego aplica las correcciones de distancia recibidas de la Referencia. Esto le permite estimar una posición mucho más precisa de lo que sería posible si se utilizaran las distancias no corregidas. Utilizando esta técnica, todas las fuentes de error son minimizadas y el resultado es una posición más precisa.

2 La aplicación de estas tecnologías en el campo arqueológico es relativamente reciente (cfr. Amado 1997). Sin embargo, su uso se ha generalizado rápidamente en la prospección de superficie como herramienta rutinaria para la correcta ubicación de yacimientos e incluso su delimitación, aunque no tanto para la documentación de estructuras y otros restos. La necesidad de una mayor precisión ha limitado su uso para trabajos que requieren mayor detalle, como es el caso de las excavaciones arqueológicas, en las que se necesita una precisión centimétrica. La incorporación del DGPS, como hemos comprobado en nuestra actuación y como comienza a reflejarse en la literatura arqueológica (cfr. Torres et al. 2004), viene a cubrir esta exigencia. de Internacional de Hayford). ${ }^{3}$ El procedimiento previo se completó con la construcción de un hito topográfico en el propio yacimiento, referenciado con coordenadas precisas, que sirvió de soporte fijo para la instalación de la estación base. De esta forma, ha sido posible conseguir una precisión del orden de los 2-3 cm en la ubicación de cada punto.

Tras la captura de datos, el software de descarga utilizado fue el programa Ski-Pro de Leica, v. 2.5 y los puntos exportados a Autocad, soporte sobre el que se dibujaron las estructuras o proyectaron los puntos.

Desde nuestro punto de vista, la tecnología GPS y poder contar con un profesional gestionando el sistema han sido una apuesta importante por la rapidez y precisión conseguida en la adquisición y registro de datos. Ello ha permitido capturar y gestionar más de 65000 puntos sin interrumpir de manera significativa el proceso de excavación, registrar todos los elementos de interés al momento y poder disponer de representaciones planimétricas de los restos descubiertos prácticamente al día.

Por otra parte, el sistema de registro y documentación empleado se concibió con objeto de integrar los diferentes archivos en un Sistema de Información Geográfica, lo que facilita enormemente la gestión posterior de la información. Esta tarea se inició durante la campaña de excavación, recopilando diferentes fuentes cartográficas (topografía a diferentes escalas, mapas de suelos, fotografías áreas...) y poniendo las bases del sistema.

De cara a plasmar gráficamente los resultados de la excavación y pensando en las tareas divulgativas posteriores, se llevó a cabo un ensayo de reconstrucción virtual del yacimiento. Para ello se contó con la colaboración del grupo GIGA de la Universidad de Zaragoza dirigido por F. Serón. El planteamiento fue generar una serie de imágenes

3 Para poder transformar las coordenadas del sistema WGS84 al sistema local ED50 es necesario realizar una transformación tridimensional entre ambos sistemas de referencia. Los parámetros que relacionan el sistema global con el local son siete: tres traslaciones a lo largo de los ejes X, Y y Z, tres rotaciones alrededor de estos mismos ejes y un factor de escala. Estos parámetros pueden ser calculados con carácter global (por ejemplo, para toda la península), con carácter regional (para una provincia) o con carácter local (para la zona de trabajo). En nuestro caso prescindimos de aplicar transformaciones globales (p. ej., IBERIA UTM30 EGM96) o regionales (como la elaborada por el ICC, útil para la franja oriental de la comunidad) y optamos por calcular un sistema de transformación local, ajustado a la zona de trabajo. 


\section{LA EXCAVACIÓN}

de las diferentes fases de ocupación documentadas que mostraran, a diferentes escalas, una recreación de los paisajes y estructuras sobre la base de la documentación obtenida y estudiada hasta ese momento (fig. 3).

En definitiva, a pesar de tratarse de una intervención de urgencia, en todo momento se ha pre- tendido desarrollar una actuación con el máximo control posible, tanto en el proceso de excavación como en el de registro. Es evidente que la aplicación de esta metodología propició el hallazgo de los restos que nos permitieron identificar un campamento mesolítico que en anteriores actuaciones había pasado desapercibido.
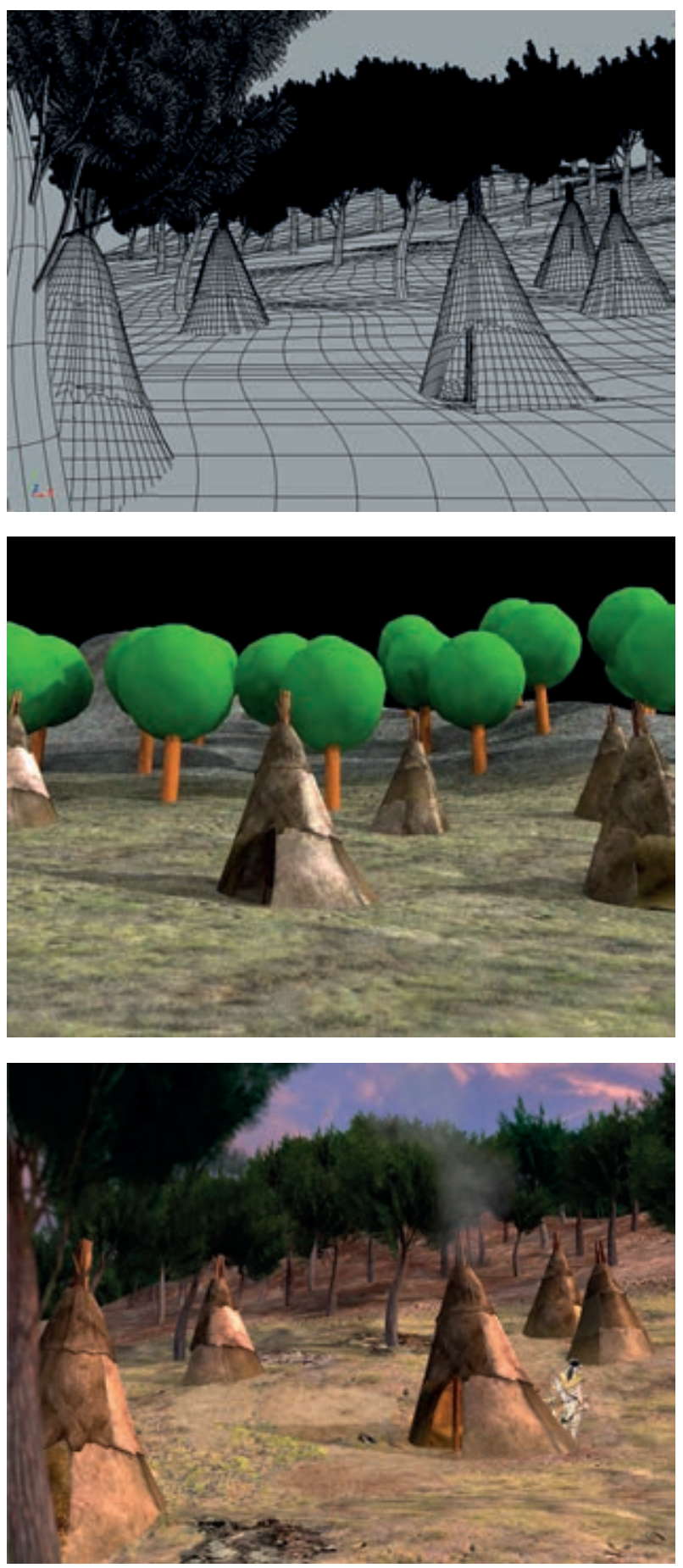

Figura 3. Proceso de reconstrucción virtual. 


\subsection{ESTRATIGRAFIA}

\subsubsection{UNIDADES SUPERIORES}

\section{Nivel superficial}

Tierra arcillosa bastante suelta y mezclada con gravilla, carboncillos y raíces. Coloración variable según el cuadro con una gradación que va desde un marrón claro-amarillento a un marrón oscuro. Es un nivel generado por el arado. Tanto en los perfiles como en planta se reconocen sus marcas características (figs. 4 y 5). El material que aparece, cerámica a mano y algo de sílex, se encuentra desplazado.

\section{UE 1005}

Arcillas naturales. Aparecen por debajo de la formación de ladera (UE 1637) en el cuadro 41C, sect. 1-2, a una cota de 402.070. Estas arcillas se encuentran acondicionadas y retalladas para asentar en ellas la cabaña mesolítica.

\section{UE 1349}

Cubeta insertada dentro del nivel de formación de ladera (UE 1637), rellena por tierra cenicienta, suelta y bastante heterogénea con abundantes cantos rodados (módulo variable de entre 10 a $20 \mathrm{~cm}$ ) y gravilla.

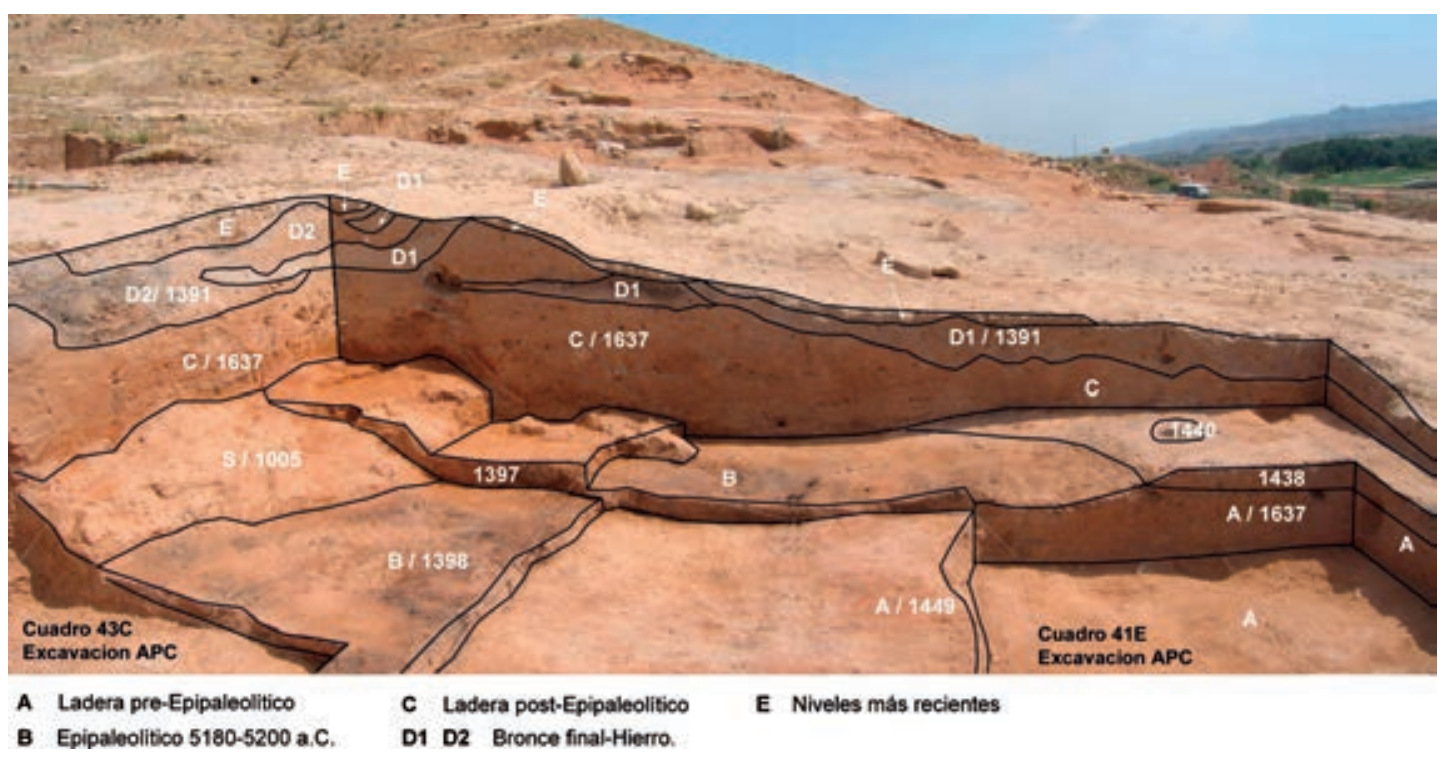

Figura 4. Vista parcial de la planta y perfiles en la zona ocupada por la cabaña mesolítica.

Forma irregular y límites de difícil definición, razón por la que no se señaló ninguna interfaz a este sedimento. Entre el material se encuentra sílex, cerámica a mano (aparentemente del Hierro) y restos óseos.

\section{UE 1362}

Interfaz de una cubeta que corta a las UE 1637 y 1351, llegando incluso a los niveles de acumulación de ladera que aparecen por debajo de los niveles de ocupación mesolíticos. Tiene forma circular y un diámetro de $61 \mathrm{~cm}$. Esta unidad y su relleno (UE 1363) eran cortados con orientación W-E por una topera (anchura máxima de unos $20 \mathrm{~cm}$ ) que atravesaba todo el cuadro.

\section{UE 1363}

Relleno de la cubeta circular 1362. Sedimento de color negro-ceniciento con abundantes carbo- nes y algo de gravilla. Fragmentos cerámicos de la Edad del Hierro y restos óseos.

\section{UE 1382}

Larga e irregular franja de tierra - anchura media de 10 a $15 \mathrm{~cm}-$, marrón claro con tonalidades algo rojizas, muy suelta y de textura arenosa. Corta claramente las UE 1637 y 1351. Además, este nivel presentaba claras marcas de haber sufrido escorrentías de agua por el interior de la unidad. Parece corresponder a una topera.

\section{UE 1384}

Relleno de la cubeta 1385. Limos arenosos, cenicientos, con abundantes cantos rodados (módulo aprox. 5-15 cm), carbones y cerámica a mano reductora. 


\section{LA EXCAVACIÓN}

\section{UE 1385}

Cubeta de la Edad del Hierro con un diámetro de $76 \mathrm{~cm}$ en su comienzo y de unos $45-50 \mathrm{~cm}$ de diámetro en su base. Corta tanto a los niveles de formación de ladera, como a los de la ocupación mesolítica.

\section{UE 1391}

Sedimento arcilloso de color amarillento con variaciones más grisáceas, textura plástica y consistencia leve. Se reconoce en el cuadro 41C, perfil $\mathrm{N}$, dispuesto entre el nivel superficial y la formación de ladera (UE 1637). En ese perfil se constata una excavación en forma de cubeta que constituye la cuenca de recepción de esos sedimentos a la vez que recorta y se apoya en la formación de ladera.

\section{UE 1637}

Formación de ladera de composición limo-arcillosa. Color marrón claro-rojizo. Aparecen algunas manchas cenicientas y carboncillos diseminados por el nivel. Potencia variable, máxima hacia la parte alta de la ladera (aprox. 60-80 cm) y se va extinguiendo hacia la parte baja. Dentro de la UE 1637 aparecieron diversos elementos, cubetas, maderos carbonizados, toperas..., descritos más adelante. Poco material, cerámica a mano, huesos y algo de sílex.

\section{Capa de contacto entre la formaciónde ladera UE 1637 y niveles mesolíticos UE 1351 y 1397}

No se le dio ningún número de unidad, puesto que propiamente no es una unidad estratigráfica definible. Comparte todas las características de la formación de ladera, siendo la última talla antes de los niveles de ocupación mesolítica. Sin embargo, el hecho diferencial es la alta concentración de material lítico. Solamente en el cuadro $43 \mathrm{E}$, en el que la acumulación de ladera pierde potencia, aparecieron dos fragmentos cerámicos con aspecto del Bronce-Hierro.

\subsubsection{UNIDADES CORRESPONDIENTES A LAS FASES DE OCUPACIÓN MESOLÍTICA}

\section{UE 1351}

Esta unidad, por debajo de UE 1637, en un principio parecía único nivel de ocupación. Posteriormente, se distinguieron dos niveles horizontales, uno con aspecto ceniciento (1398) y otro de coloración más rojiza (1397).

\section{UE 1397}

Tierra arcillosa rojiza, abundantes puntos blancos y carboncillos. Diferencia nítida con la UE 1637 por encima y de la UE 1398. Es un nivel de sedimentación horizontal que, aparentemente, corresponde a un depósito generado tras el abandono de la ocupación mesolítica. Su extensión estaría determinada por el área de extensión de la cabaña. El material que aparece es todo lítico, fundamentalmente restos de talla, y algún fragmento de lámina.

\section{UE 1398}

Nivel de ocupación de textura arenosa y cenicienta, con abundantes carbones y puntos blancos, a veces de $5 \mathrm{~mm}$ de diámetro, que al tacto presentan una textura pastosa. Depósito muy heterogéneo. Es este nivel y el color ceniciento que presenta lo que comienza a definir el diámetro y la forma circular de la cabaña. Su extensión ocupa toda el área de la cabaña. El material que aparece es todo lítico, lascas, algunas láminas, un percutor y abundantes restos de talla.

\section{UE 1441}

Nivel arcilloso de color rojizo oscuro con abundantes manchas y puntos blanquecinos de cal, depurado y bastante homogéneo. Escaso material, todo lítico, mayoritariamente restos de talla y algunas pequeñas lascas.

\section{UE 1442}

Nivel de ocupación de color grisáceo con abundante ceniza, a veces se entremezcla con manchas arcillosas rojizas. Heterogénea, poco compacta, de textura arenosa. Aparece gran cantidad de material lítico, sobre todo restos de talla y fragmentos de láminas. En el cuadro 43 D.1 se descubrió una pequeña acumulación de material lítico (láminas, lascas y restos de talla). Este nivel se apreciaba mejor en el centro de lo que sería la cabaña, aún así se pudo diferenciar en toda la extensión de la misma. Por debajo de UE 1441 y por encima de UE 1449.

\section{UE 1449}

Nivel que se encontraba por debajo de UE 1442, de color amarillento o marrón claro. Tierra bastante suelta, se encuentran algunos carboncillos dispersos. Tiene todas las características visuales del nivel de formación de ladera, pero la aparición de algunos materiales líticos hace pensar que sea una capa de contacto entre el nivel de ocupación y el de 
formación de ladera, probablemente la superficie de esta recortada. En el centro de la cabaña y junto a la cubeta UE 1450 que se interpretó como un hogar, aparecía esta superficie totalmente enrojecida, con fuertes manchas de oxidación producto de la acción del fuego o brasas.

\section{UE 1450}

Cubeta situada en cuadro 43D sect. 1 . Tiene forma circular con unas dimensiones de 58 por $40 \mathrm{~cm}$ y profundidad máxima de $22 \mathrm{~cm}$. Aparece rellena con materiales finos de color ceniciento y carboncillos. Empieza a detectarse al terminar

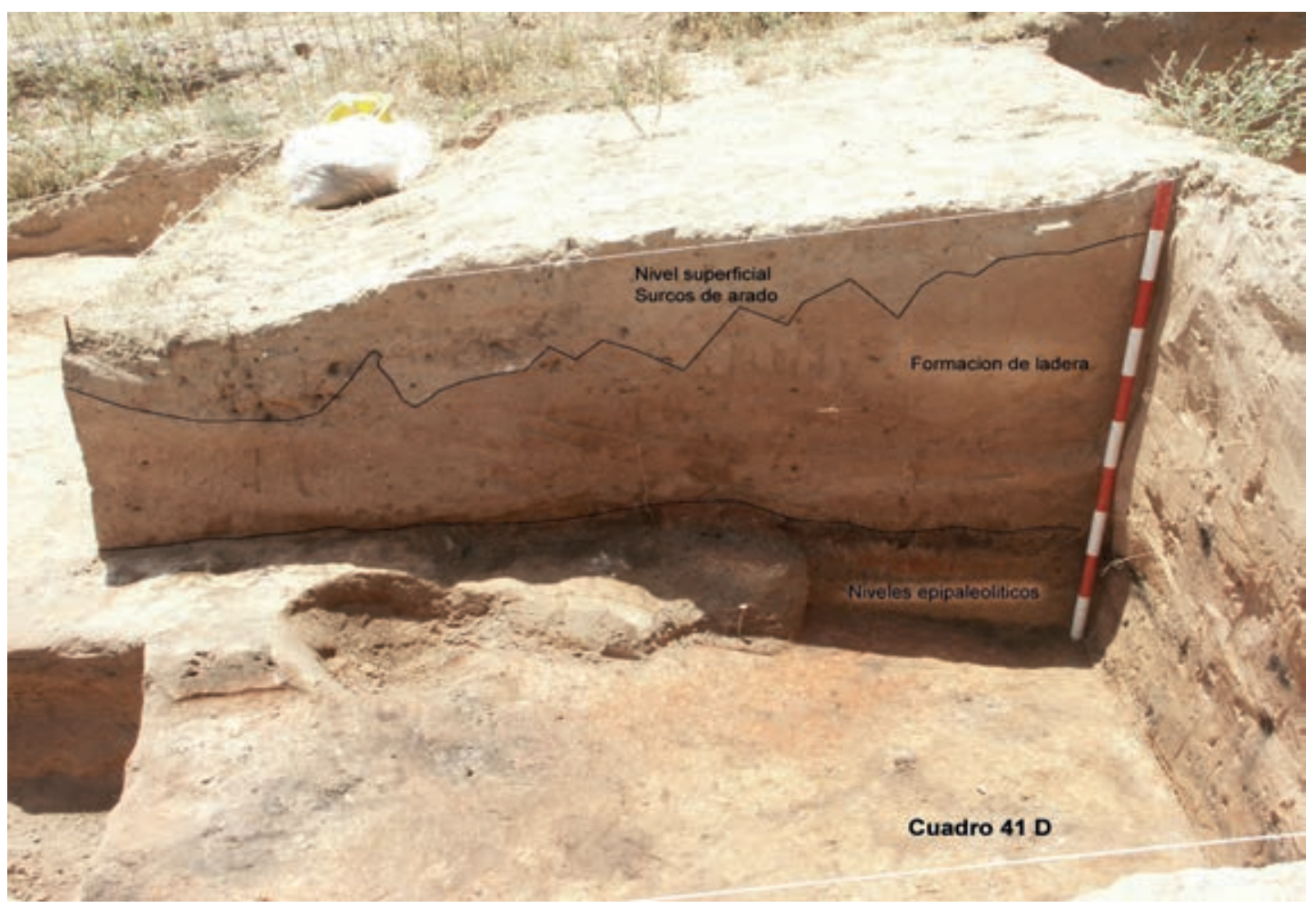

Figura 5. Cuadro 41D, perfil O. Se aprecia la sucesión de niveles arcillosos y cenicientos por debajo de la formación de ladera.

de excavar la UE 1442. Se considera el hogar central de la cabaña.

\section{UE 1451}

Agujero de poste localizado en cuadro 43D.1. Contiene un relleno de tierra limosa, cenicienta con algún carboncillo, bastante heterogénea y muy suelta, cubierta por 1442 y dentro 1449 . Escaso material lítico.

\section{UE 1452}

Pequeña huella de un poste. Contiene una tierra limosa rojiza, con algo de ceniza y abundante gravilla. Se localiza en cuadro 43D.3. No apareció nada de material.

\section{UE 1463}

Recorte sobre la ladera (1005 y 1637) correspondiente a la estructura del fondo de cabaña.
Diámetro máximo de $465 \mathrm{~cm}$, forma redondeada con tendencia oval.

\section{UE 1465}

Agujero de un poste en cuadro 41D.2. Contenía una tierra muy heterogénea compuesta por cenizas, carboncillos abundantes, manchas blancas de cal, arcillas rojizas y pequeñas bolsadas de tierra marrón.

\subsubsection{OTRAS UNIDADES FUERA DE LA CABAÑA}

\section{UE 1438}

Nivel de ocupación mesolítico ceniciento, arenoso, con carboncillos y bolsadas de arcillas rojizas, muy heterogéneo. Todo el material aparecido es lítico: lámina de dorso, algunas lascas y sobre todo restos de talla. Este nivel junto con las UE 1440 y 1439 se encuentra claramente separa- 


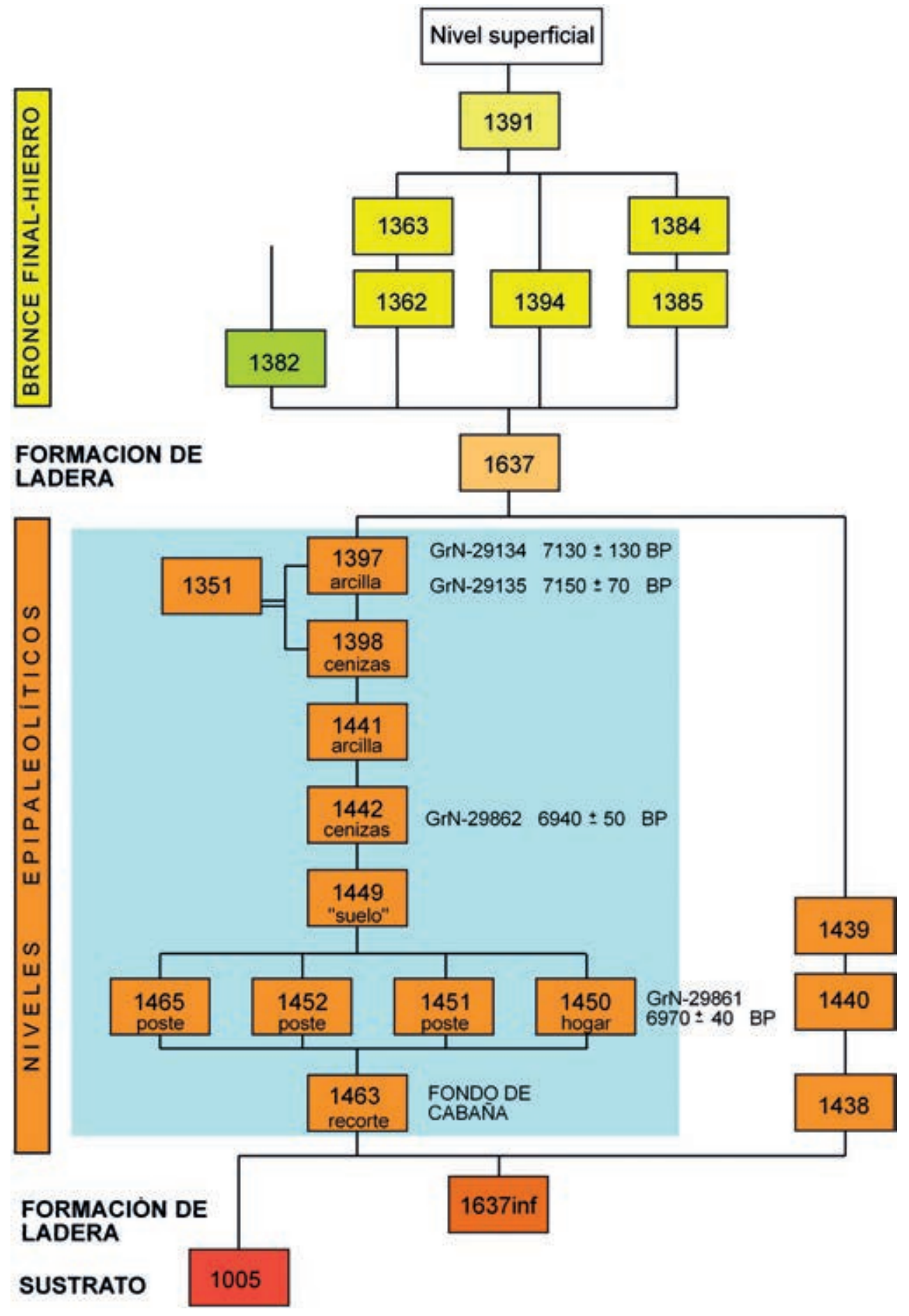

Figura 6. Secuencia estratigráfica registrada en los cuadros 39-43 CDE de la ladera SO. 
do de la cabaña (UE 1463), pudiendo indicar la existencia de otras cabañas en las inmediaciones.

\section{UE 1439}

Sedimento limoso amarillento, muy depurado y homogéneo, bien diferenciado de los niveles circundantes, parece un relleno del agujero realizado para la colocación del poste.

\section{UE 1440}

Huella cenicienta de un pie derecho o poste. Ya no conservaba nada de madera tan solo quedaba una ceniza bastante depurada con algunos carboncillos. Se encuentra asociado al relleno 1439.

En síntesis, la estratigrafía documentada en este sector, y reproducida en la matriz que se adjunta (fig. 6), muestra una secuencia con cuatro episodios claramente diferenciados:

- Un tramo superior en el que se reconocen intrusiones relacionadas con los poblados del Bronce Final o de la Primera Edad del Hierro. Estas intrusiones en algunos casos tienen la forma de cubetas rellenas por sedimentos grisáceos. En ellas se encuentra algún fragmento de cerámica modelada a mano sin valor diagnóstico.

- Las intrusiones del Hierro perforan o se apoyan en un potente depósito de ladera conformado por materiales finos de naturaleza limo-arcillosa. Hacia la base de esta acumulación comienzan a aparecer restos líticos.

- Por debajo de este depósito detrítico, en el tramo inferior de las secuencias, se reconoce una sucesión de niveles rojizos (arcillosos) y grises (cenicientos). Estos niveles rellenan y se apoyan en una superficie horizontal asociada a un recorte en la ladera con forma casi circular que parece corresponder a un fondo de cabaña. Dentro de esta estructura, a su vez, se identifican tres agujeros de poste y una cubeta central con sedimento ceniciento que hemos interpretado como el hogar. Fuera de esta supuesta cabaña, pero ligadas a este mismo episodio se reconocen otras unidades estratigráficas. Todos estos niveles han proporcionado materiales líticos entre los que se reconocen hojitas de dorso y geométricos. No se ha detectado cerámica modelada a mano.

- Por debajo de los niveles mesolíticos, de nuevo encontramos un depósito de ladera con aspecto similar al anterior pero sin materiales arqueológicos, así como las arcillas naturales del sustrato. Tanto la acumulación de ladera como las arcillas han sido recortadas y sirven de base para la instalación de la ocupación mesolítica.

\subsection{MATERIALES ${ }^{4}$}

Los materiales recuperados en los diversos niveles de la secuencia suponen unos 2000 restos líticos que se estudian en el capítulo correspondiente. Configuran una industria caracterizada por la relativa abundancia de láminas pequeñas y laminitas, de las que abundan los fragmentos correspondientes a los extremos proximales y distales. A partir de esos soportes, se han fabricado geométricos (trapecios) con retoque abrupto y laminitas de dorso, algunas de ellas apuntadas. La relación entre ambos grupos parece fluctuar, con predominio de las laminitas en la base de la secuencia y el aumento de los geométricos, en particular de los trapecios hacia los niveles superiores (fig. 11).

Fuera de estos dos grupos tipológicos apenas se han identificado otras piezas. Tan solo se reconocen varias lascas y láminas con retoques parciales, varias lascas grandes con denticulados de aspecto macrolítico y un posible buril. A lo largo de toda la secuencia son algo más frecuentes las laminitas con micorretoques aparentemente de uso. En el tramo superior también se han identificado tres cantos rodados de caliza con huellas de percusión y dos conchas (Columbella rustica) perforadas (figs. 7, 8, 9, 10).

En casi todos los niveles aparece algún núcleo, normalmente informe. También son frecuentes las lascas y láminas con córtex y otros subproductos asociados a los procesos de talla (laminitas de cresta, algún recorte de núcleo, abundantes esquirlas...), lo que parece indicar que sobre el lugar se procedió a la obtención de soportes de mediano o pequeño tamaño y a la elaboración de piezas, aparentemente geométricas, y laminitas de dorso. Muchos de los restos de talla, así como algunas piezas, aparecen fuertemente alterados por la acción del fuego.

4 Los efectivos de esta unidad están, en cierto modo, desvirtuados por la gran cantidad de esquirlas y «débris», probablemente provocados por la acción del fuego. 
LA EXCAVACIÓN

UE 1351
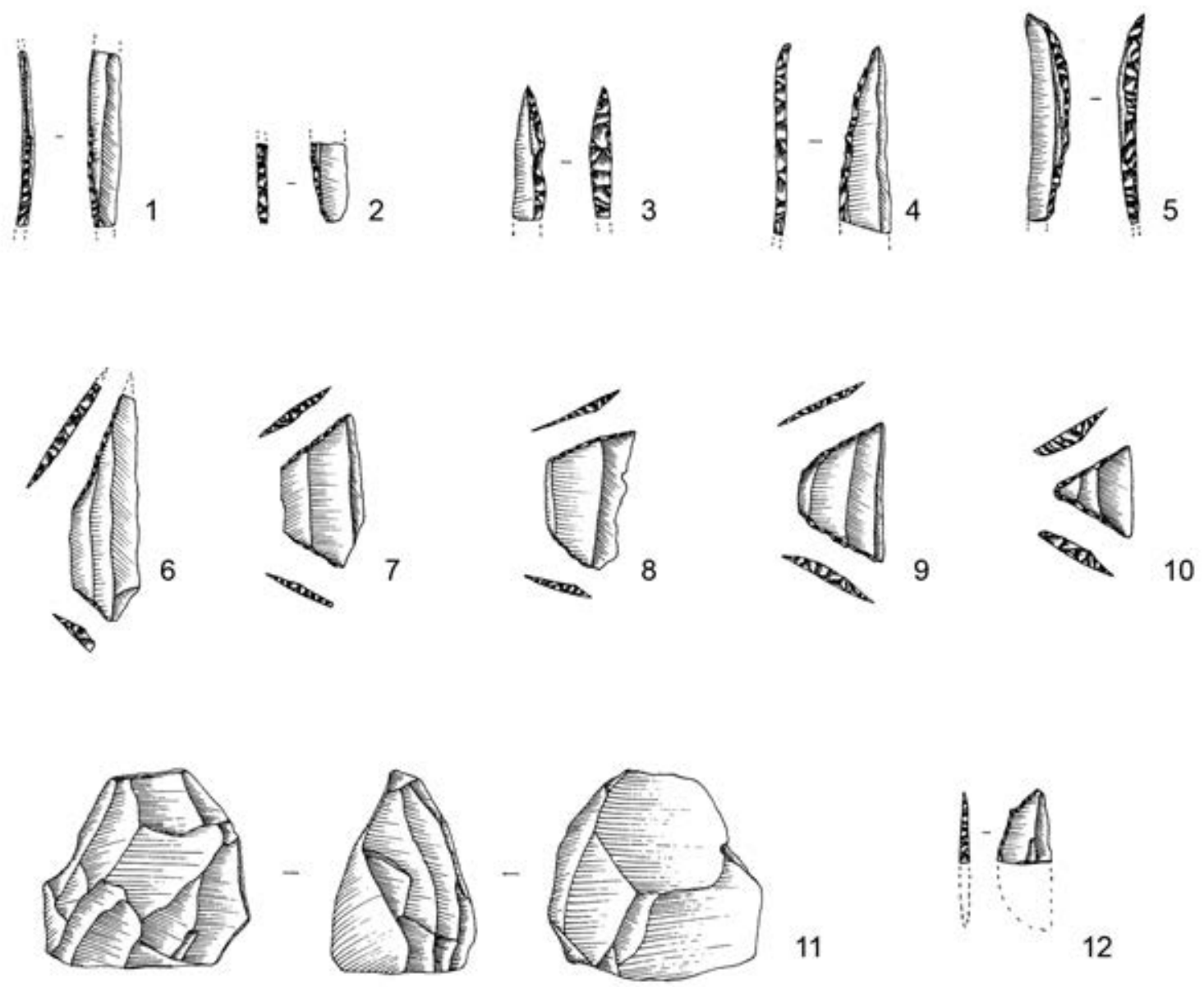

10

11
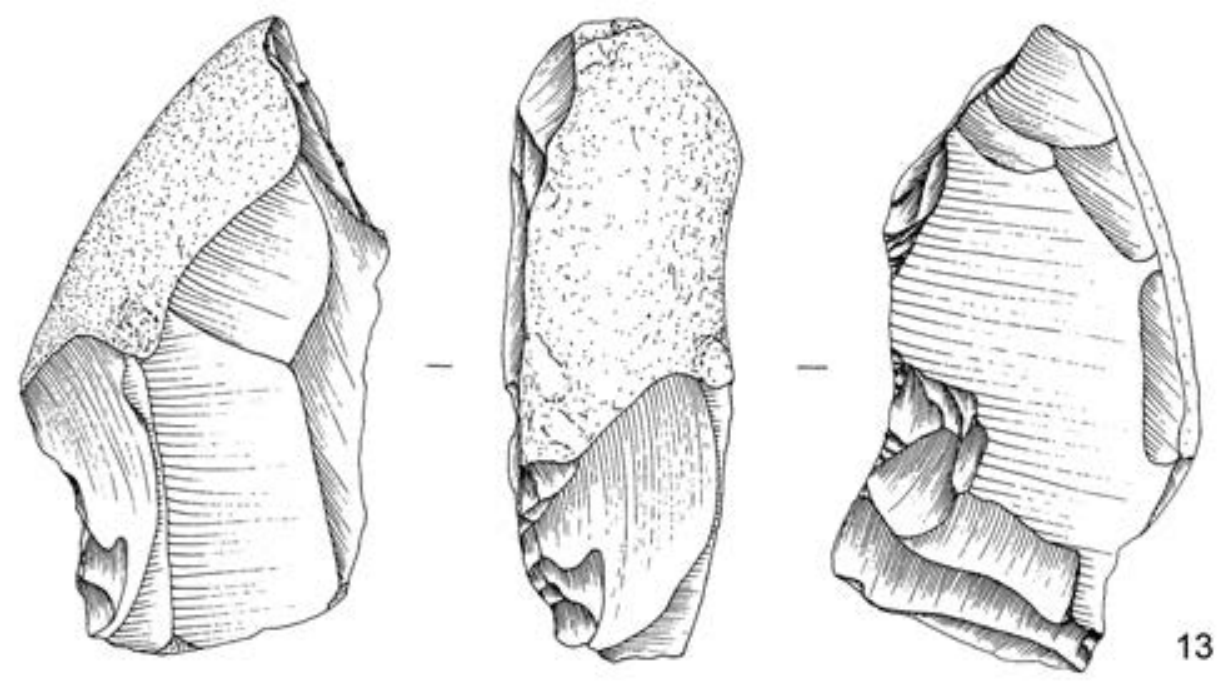

(2)

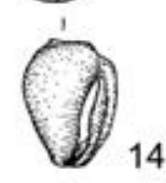

Figura 7. Industria lítica y C. rustica (14 y 15). 
UE 1397
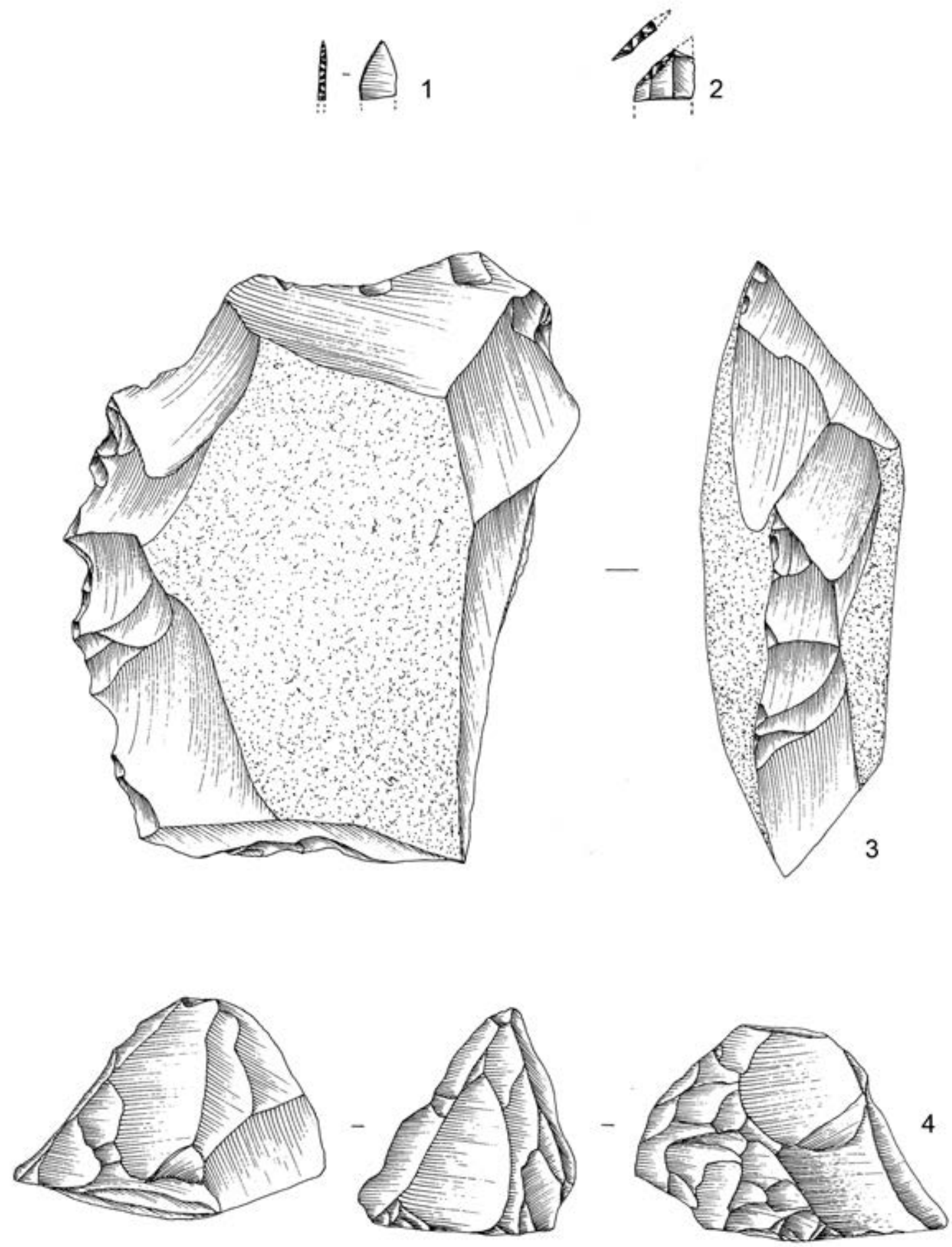

Figura 8. Industria lítica. 
UE 1398

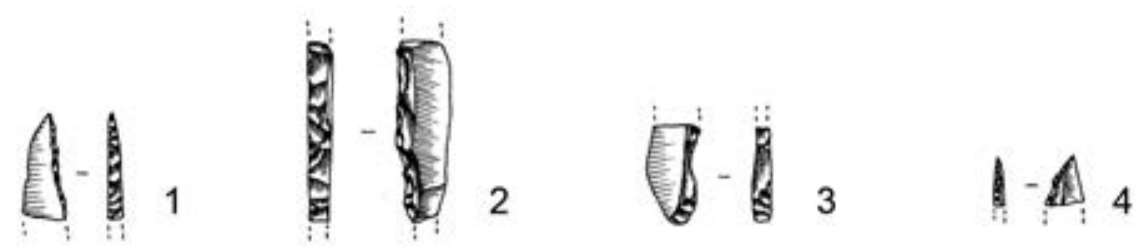
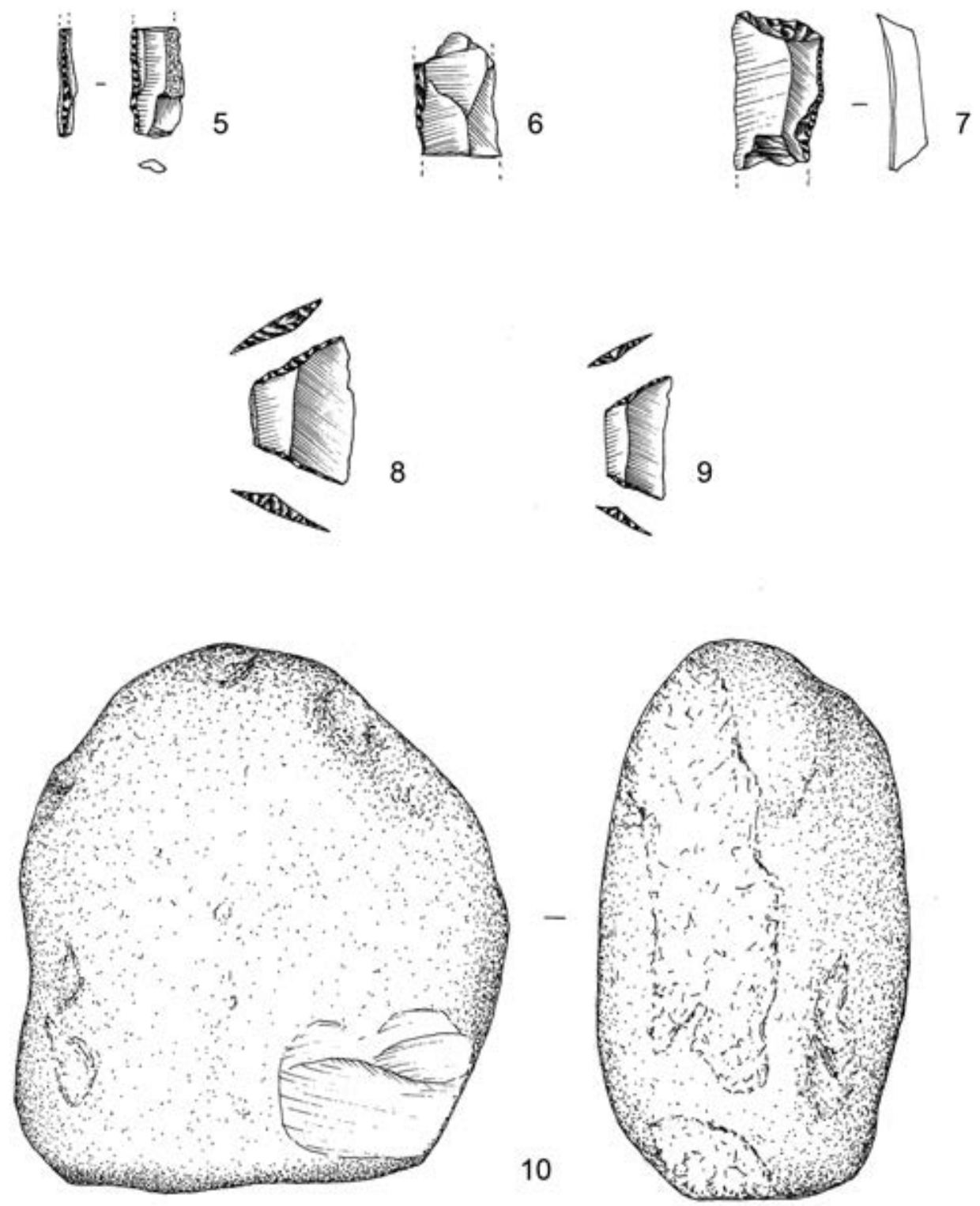

Figura 9. Industria lítica. 
UE 1441
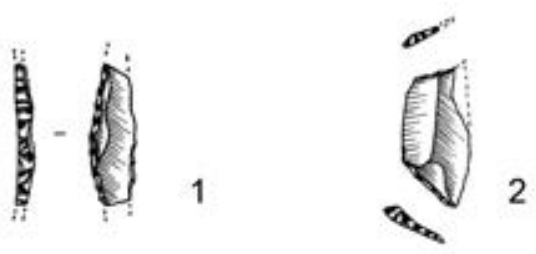

UE 1442

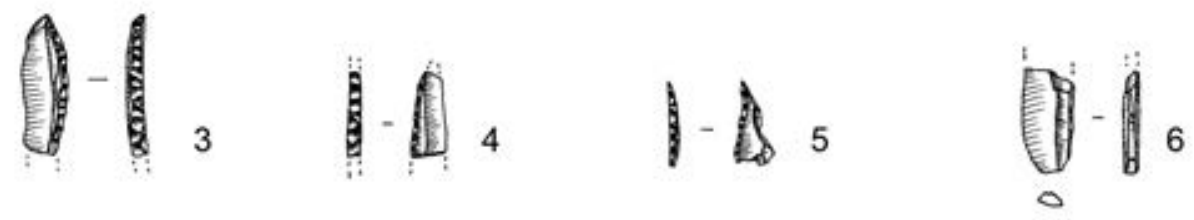
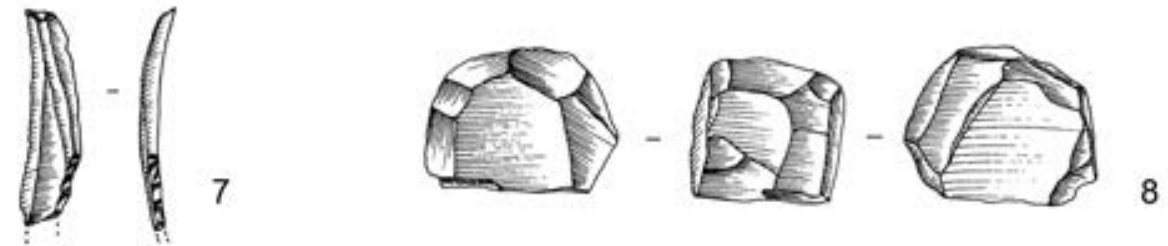

UE 1449

UE 1450
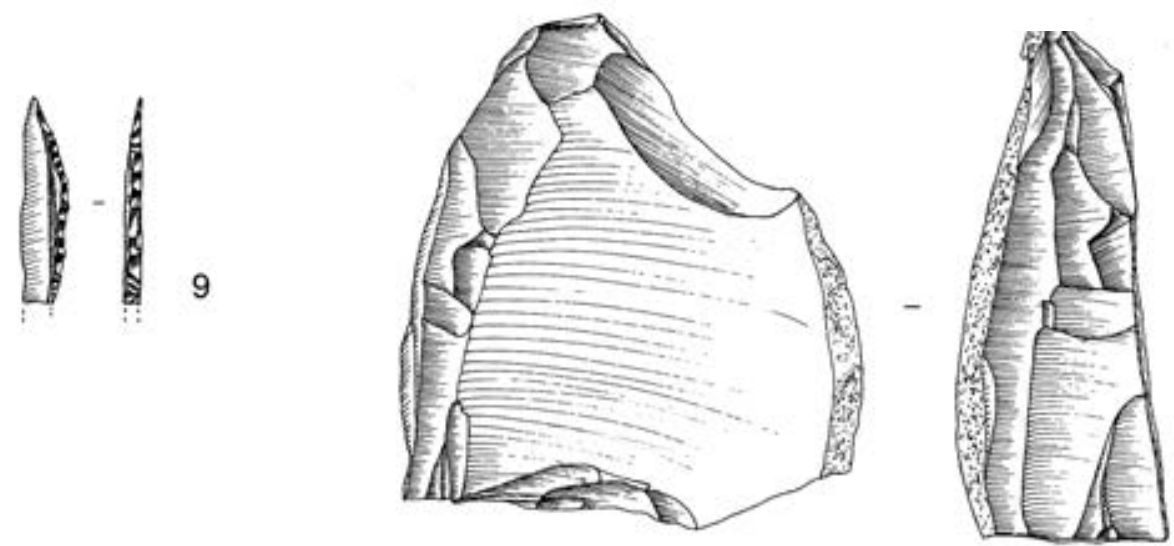

।

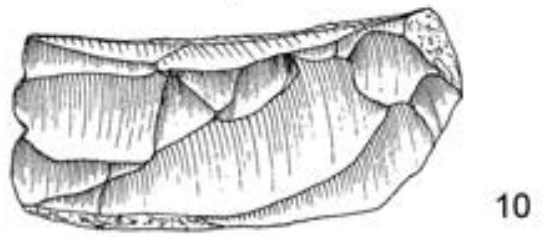

Figura 10. Industria lítica. 


\begin{tabular}{|c|c|c|c|c|c|c|c|c|c|}
\hline$U E$ Grupos & $\begin{array}{c}\text { Lámina } \\
\text { dorso }\end{array}$ & $\begin{array}{l}\text { Laminita } \\
\text { de dorso }\end{array}$ & $\begin{array}{l}\text { Lta. dorso } \\
\text { apuntada }\end{array}$ & Trapecio & Triángulo & Segmento & Columbela & Total piezas & $\begin{array}{c}\text { Total } \\
\text { efectivos }\end{array}$ \\
\hline 1351 & 1 & 2 & 3 & 5 & 1 & 1 & 2 & 13 & 708 \\
\hline 1397 & & & 1 & 1 & & & & 2 & 195 \\
\hline \multirow[t]{2}{*}{1398} & 1 & 3 & 2 & 2 & & & & 8 & 164 \\
\hline & \multicolumn{2}{|c|}{ Total dorsos } & 13 & \multicolumn{3}{|c|}{ Total geométricos 10} & & & \\
\hline 1441 & & 1 & & 1 & & & & 2 & 132 \\
\hline 1442 & & 4 & & & & 1 & & 5 & 5041 \\
\hline \multirow[t]{2}{*}{1449} & & & 1 & & & & & 1 & 47 \\
\hline & \multicolumn{2}{|c|}{ Total dorsos } & 7 & \multicolumn{2}{|c|}{ Total geométricos } & 2 & & & \\
\hline
\end{tabular}

Figura 11. Principales unidades de la secuencia y distribución del material arqueológico.

\subsection{ESTRUCTURAS}

Las estructuras documentadas corresponden a lo que parecen ser los restos de un fondo de cabaña (fig. 12). El rasgo principal es un recorte con forma aproximadamente circular (UE 1463), excavado en la ladera sobre las arcillas del sustrato (UE 1005) hacia el cuadro 41C y sobre la formación de ladera (UE 1637inf) en los cuadros 41-43D, generando, así, una plataforma completamente horizontal. El contorno se ha podido reconocer con relativa claridad en los cuadros 41C, 39D, 43D y parcialmente en 43C. Hemos de tener en cuenta que este cuadro $43 \mathrm{C}$ así como $41 \mathrm{E}$, donde falta el perímetro, habían sido ya excavados por APC perforando parcialmente la estructura. No obstante, con los tramos documentados es posible reconstruir su forma aproximada.

La planta tiene forma circular con tendencia oval. En el eje mayor conservado su longitud es considerable, $4,80 \mathrm{~m}$, y su superficie mínima, $12,88 \mathrm{~m}^{2}$, para un perímetro de $15,47 \mathrm{~m}$. Sus cotas oscilan entre los 400,80 m en el cuadro $43 \mathrm{C} \mathrm{y}$ $400,57 \mathrm{~m}$ en 41D, apenas unos $23 \mathrm{~cm}$ de desnivel. No obstante, el recorte de la ladera parece ascender algo más en el cuadro $41 \mathrm{C}$, conforme aparece el sustrato arcilloso, hasta los 400,94 m.

En el interior de la cabaña (cuadro 43D, sect. 1), en posición ligeramente excéntrica, se reconoce una cubeta circular de $65 \mathrm{~cm}$ por 59 y unos $20 \mathrm{de}$ profundidad que apareció colmatada por un sedimento ceniciento, carboncillos y algún elemento lítico (UE 1450). Tiene todo el aspecto de tratarse del hogar. En sus inmediaciones, hacia el sector 2 del cuadro 41D, el suelo aparecía fuertemente oxidado, probablemente como consecuencia de la acción del fuego del hogar inmediato. Alrededor de este hogar se detectaron tres agujeros (UE 1450, 1451 y 1465) con diámetros máximos variables $(23,13$ y $8 \mathrm{~cm})$ que parecen corresponder a los postes de sustentación de la cabaña (fig. 12).
Fuera de la misma, en el cuadro 39E, se localizó otro agujero de poste que parece corresponder a una estructura distinta. Algunos de los depósitos que rellenaban el fondo de la cabaña estaban perforados por dos cubetas de la Primera Edad del Hierro (UE 1385 y 1362).

Es probable que el sistema de cubrición de la cabaña descansara en los tres postes centrales y se completara con una serie de troncos de menor calibre que fueran convergiendo hacia ellos y que soportarían una cubierta de ramas o pieles (fig. 13). En la unidad 1398, donde son frecuentes los carbones, se han detectado algunos troncos relativamente largos, no muy gruesos, que parecen dispuestos de forma radial hacia el centro de la cabaña. Alguno de los cuales, aunque muy degradado, conservaba una longitud de casi $1 \mathrm{~m}$ (fig. 14).

La extensión de la ocupación es difícil de estimar dada la transformación que ya ha experimentado la zona. No obstante, hay que tener en cuenta que se ha detectado en los $12 \mathrm{~m}^{2}$ intervenidos y que en todos los perfiles se observa la continuación de estos niveles, lo que implica su extensión por unos $30-35 \mathrm{~m}^{2}$. Por otra parte, la cita de hallazgos de sílex y cenizas en varias de las catas realizadas en su día por APC apuntan que la ocupación podría extenderse de forma más o menos continua por $30 \mathrm{~m}$ lineales en el sentido de la ladera. Por la misma razón, habría que valorar la posibilidad de que determinados depósitos cenicientos, como los localizados a $40 \mathrm{~m}$ hacia el $\mathrm{SO}$, junto a las casetas de la obra, pudieran corresponder a este mismo fenómeno, dada la morfología de los depósitos y la presencia ocasional de sílex por la zona.

\subsubsection{DISPERSIÓN DE MATERIALES}

La distribución observada a nivel horizontal no resulta especialmente significativa debido a dos factores: 
1. El proceso de excavación ha condicionado la recuperación y el control del material. Casi todo el cuadro 43C y parte del 41C, así como el cuadro $41 \mathrm{E}$ y parte del $41 \mathrm{D}$, estaban afectados por sendos sondeos realizados por actuaciones anteriores. Desconocemos los restos recuperados en estas zonas.
2. Buena parte de los restos líticos, especialmente los geométricos, se han recuperado en niveles $(1351,1397,1398)$ que probablemente han experimentado cierto desplazamiento. Los niveles que se encuentran en su sitio $(1441,1442$, 1449 ...), rellenando la cabaña, han proporcionado menos restos.
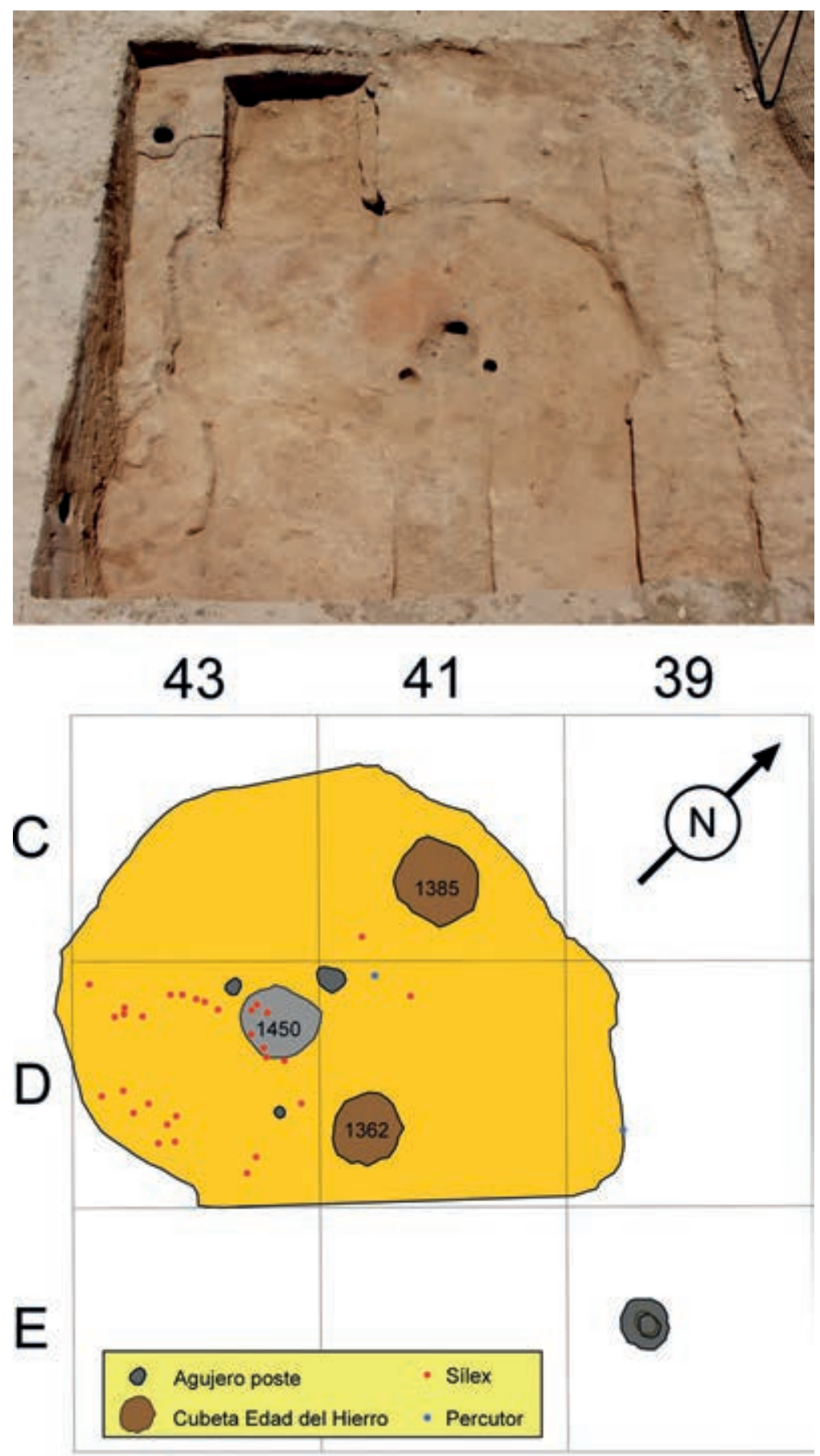

Figura 12. Vista cenital y planimetría de la cabaña mesolítica con las principales estructuras asociadas. 


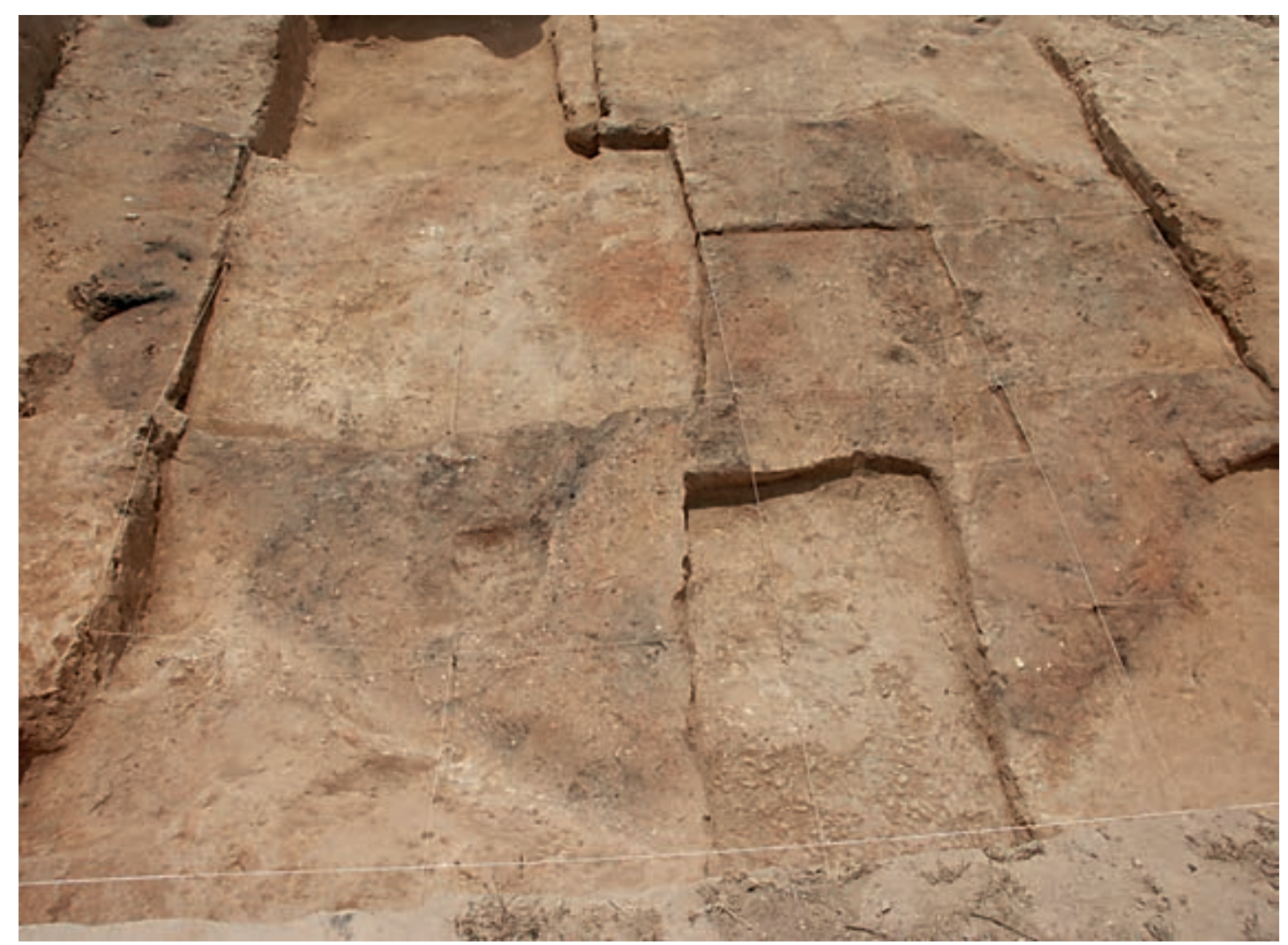

Figura 13. Vista general de la planta de la cabaña.
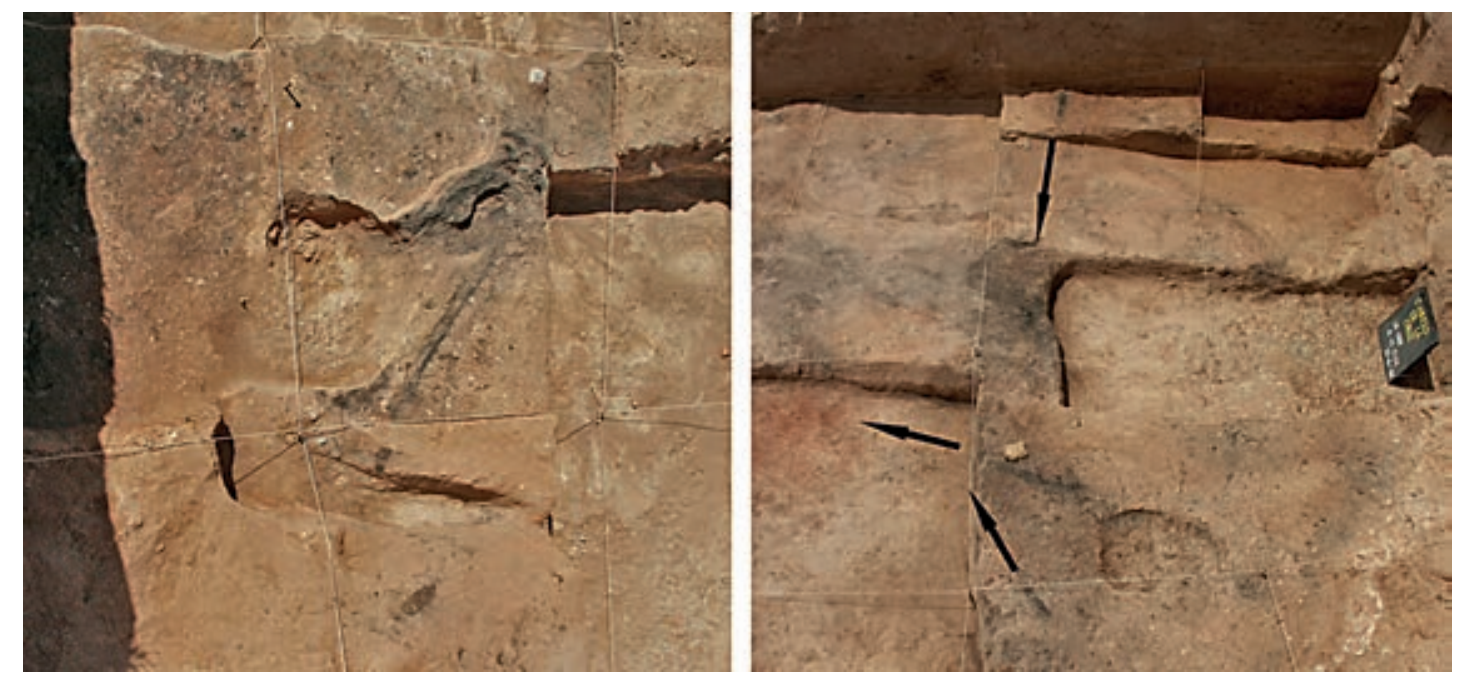

Figura 14. UE1398. Restos de la cubierta. Los troncos caídos convergen hacia el interior.

Dicho esto, la distribución muestra un patrón prácticamente aleatorio. Tal vez debamos anotar cierta concentración de restos, fundamentalmente laminitas de dorso, en torno al hogar central (fig. 15).

Sí que se puede confirmar la presencia de una alta concentración de esquirlas y débris como consecuencia del estallido de piezas líticas en el entorno del hogar. Esta concentración va ligada a cierta acumulación de finas cenizas procedentes de la combustión, seguramente depositadas en caliente sobre el suelo de la cabaña, lo que produjo una acusada rubefacción en varios sectores con el típico color rojizo. 


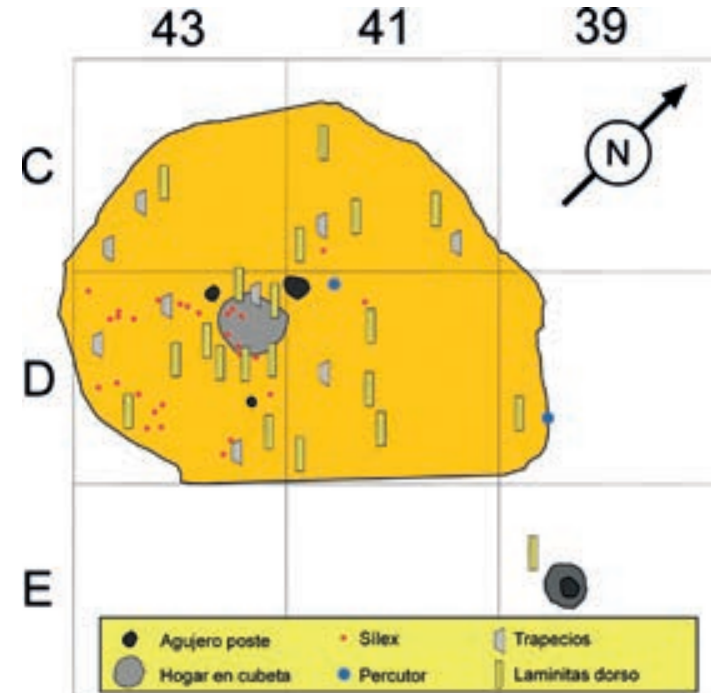

Figura 15. Distribución de restos líticos en el ámbito de la cabaña. Se han considerado conjuntamente todas las unidades estratigráficas.

La distribución vertical de los restos muestra cierta ordenación. Desde el punto de vista estratigráfico, consideramos la existencia de dos paquetes principales formados por diversas unidades con contingentes materiales claramente diferenciados, además de restos marginales de lo que parece una ocupación anterior (fig. 16).

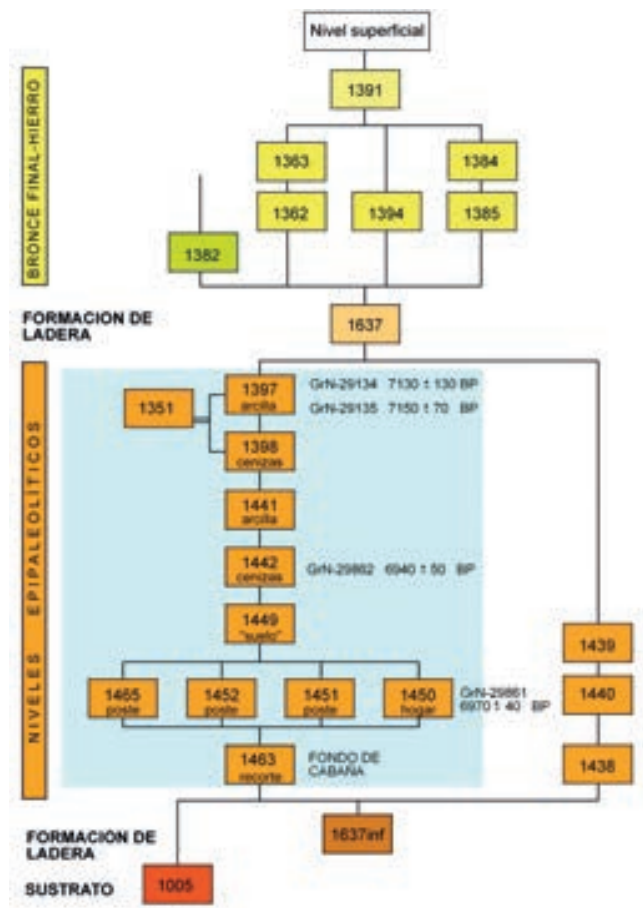

1. La parte superior de la secuencia integrada por las unidades 1351, 1397 y 1398. Parece un combinado estratigráfico en el que se mezclan restos del derrumbe de las estructuras de la cabaña mezcladas con otros materiales arrastrados procedentes de las inmediaciones. En este paquete se da la mayor concentración restos y, por extensión, de geométricos y dorsos. La proporción de ambos grupos está equilibrada, si bien es el tramo en el que se encuentra un mayor número de geométricos, especialmente trapecios, junto con las dos conchas de Columbella rustica identificadas.

2. La parte inferior formada por las unidades 1441,1442 y 1449. Corresponden a los niveles de ocupación de la cabaña, incluyendo el suelo de la misma. En este paquete, se da un predominio evidente de los dorsos, aunque el total de elementos tipológicos es muy bajo y el de efectivos totales está distorsionado al alza por la gran cantidad de esquirlas y débris.

3. Queda al margen la unidad 1438, un depósito cortado por el propio fondo de cabaña que denota un momento anterior. Lamentablemente, apenas se pudo excavar y no ha proporcionado material significativo. Apuntar simplemente el hallazgo de una laminita de dorso y un porcentaje relativamente alto de piezas con córtex.

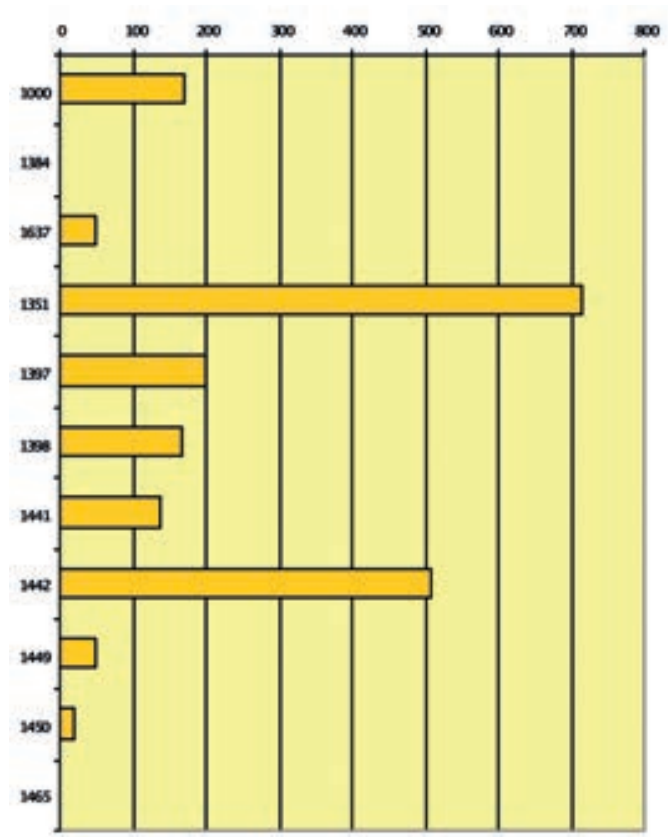

Figura 16. Matriz estratigráfica y distribución de la frecuencia de restos a lo largo de la secuencia. 


\begin{tabular}{|c|c|c|c|c|}
\hline Unidad & Trapecios & Triángulos & Segmentos & Mas dorso \\
\hline 1000 & 0 & 0 & 0 & 0 \\
\hline 1384 & 0 & 0 & 0 & 0 \\
\hline 1637 & 0 & 0 & 0 & 0 \\
\hline 1351 & 5 & 1 & 1 & 5 \\
\hline 1397 & 1 & 0 & 0 & 1 \\
\hline 1398 & 2 & 0 & 0 & 5 \\
\hline 1441 & 1 & 0 & 0 & 1 \\
\hline 1442 & 0 & 0 & 1 & 4 \\
\hline 1449 & 0 & 0 & 0 & 1 \\
\hline 1450 & 0 & 0 & 0 & 0 \\
\hline \multirow{3}{*}{1438} & 0 & 0 & 0 & 0 \\
\hline & 0 & 0 & 0 & 1 \\
\hline & Trapecios & Triangulos & Segmentos & Itas dorso \\
\hline 1351 & & ㅁ & 口 & \\
\hline 1397 & ㅁ & & & \\
\hline 1398 & & & & \\
\hline 1441 & 口 & & & \\
\hline 1442 & & & 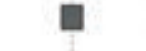 & \\
\hline 1449 & & & & \\
\hline 1450 & & & & \\
\hline 1438 & & & & 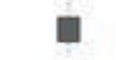 \\
\hline
\end{tabular}

Figura 17. Distribución de la frecuencia de geométricos y dorsos a lo largo de la secuencia.

En función de todo ello, podemos apuntar una serie de hipótesis para entender la distribución horizontal y vertical de los restos recuperados:

1. La concentración de geométricos y dorsos en la parte alta de la secuencia seguramente es consecuencia de la acumulación de elementos arrastrados de las inmediaciones, conformando una especie de compuesto en el que se mezclan restos procedentes de similares cabañas o diferentes unidades funcionales ${ }^{5} \mathrm{y}$ de horizontes cronológicos no necesariamente sincrónicos (fig. 17).

2. Por el contrario, los elementos que encontramos en la parte inferior, principalmente dorsos, en principio, sí representan el espectro propio de esta cabaña. Ahora bien, estos dorsos son en su mayoría fragmentos y piezas rotas, lo que parece apuntar a un material desechado.

3. Es de destacar la ausencia de trapecios en las unidades 1441 y 1442 que corresponden al

5 A este respecto, cabe destacar el hecho de que de los nueve núcleos identificados, siete se han recuperado en este paquete, junto con otros elementos asociados a los procesos de talla, como dos láminas de cresta y un recorte de núcleo, lo que significa que en las inmediaciones de la cabaña pudo haber un área dedicada a la talla del sílex. suelo de la cabaña y al nivel ceniciento depositado sobre él. Por el volumen de restos recuperado en estas unidades cabría esperar la presencia de alguno de estos elementos. Esta ausencia resulta un tanto llamativa pues los trapecios, más allá de sus fluctuaciones, son una constante en los yacimientos de la margen derecha del Ebro.

4. Otro aspecto a comentar de estas unidades es la presencia de elementos relacionados con la talla. Además de dos núcleos, uno de ellos recuperado en el hogar (UE 1450), se ha encontrado una laminita con cresta así como un elevado número de restos con córtex (12 piezas en la UE 1442), sobre todo lascas y laminitas. A ello hay que añadir la gran cantidad de esquirlas y débris, bien es cierto que muchos de ellos son consecuencia del estallido de piezas quemadas, ya que se localizan en torno al hogar central.

5. Ese proceso de talla parece estar destinado a la obtención de laminitas, con un elevado contingente $(13+32$ frags.), muy por encima de lo que cabría esperar según el volumen de restos recuperados.

6. En definitiva, parece que los restos identificados sobre el suelo de la cabaña denotan un nivel de abandono en el que están ausentes las piezas operativas, quedando únicamente piezas amortizadas, en mal estado, y restos de talla y laminitas probablemente destinadas a la preparación de puntas de dorso.

\subsection{DATACIONES ABSOLUTAS}

Se han obtenido cuatro dataciones absolutas que fijan la ocupación de la cabaña entre el 7150 BP y el 6940 BP en fechas convencionales, lo que corresponde aproximadamente a un horizonte cronológico, definido a partir de sus valores promediados, entre el 6000 y el 5820 cal BC.

Llama la atención que las fechas más antiguas se encuentren por encima de las más modernas en la secuencia estratigráfica, lo que en una lectura vertical meramente mecánica se pudiera interpretar como el resultado de una aparente inversión estratigráfica. Sin embargo, esa supuesta inversión está condicionada por el tipo de muestra datado y por la dinámica estratigráfica descrita. Una lectura detenida de las mismas y una interpretación basada en la dinámica de ocupación explicarían esta supuesta anomalía que no es tal, atendiendo a los siguientes argumentos: 


\begin{tabular}{|c|c|c|c|c|c|c|c|}
\hline \multirow{2}{*}{$\begin{array}{l}\text { Ref. } \\
\text { Laborat. }\end{array}$} & \multirow{2}{*}{ Descripción de la muestra } & \multicolumn{2}{|l|}{ Edad C-14 } & \multicolumn{4}{|c|}{ Rangos cal BC } \\
\hline & & $B P$ & $B C$ & $68.3 \%$ & prob. & $95.4 \%$ & prob. \\
\hline GrN-29134 & $\begin{array}{l}\text { Carboncillo Pinus halepensis } \\
\text { Peso: } 1,24 \mathrm{~g} \\
\text { UE } 1351 \\
\text { Prof.: } 84 \mathrm{~cm} \\
14.06 .04 / 18.10 .04\end{array}$ & $7130 \pm 130 \quad 5$ & 5180 & $\begin{array}{l}6204-6192 \\
6183-6172 \\
6157-6144 \\
\mathbf{6 1 0 3 - 5 8 7 4} \\
5860-5847\end{array}$ & $\begin{array}{l}0.030348 \\
0.024846 \\
0.032355 \\
\mathbf{0 . 8 8 0 2 3 7} \\
0.032214\end{array}$ & $6244-5731$ & 1 \\
\hline GrN-29135 & $\begin{array}{l}\text { Carboncillo Pinus halepensis } \\
\text { Peso: } 2,12 \mathrm{~g} \\
\text { UE } 1397 \\
\text { Prof.: } 117 \mathrm{~cm} \\
18.06 .04 / 18.10 .04\end{array}$ & $7150 \pm 70 \quad 5$ & 5200 & $\begin{array}{l}\mathbf{6 0 7 9 - 5 9 7 8} \\
5946-5922\end{array}$ & $\begin{array}{l}\mathbf{0 . 8 7 4 6 5 7} \\
0.125343\end{array}$ & $\begin{array}{l}6211-6135 \\
\mathbf{6 1 2 2}-5891\end{array}$ & $\begin{array}{l}0.10076 \\
\mathbf{0 . 8 9 9 2 4}\end{array}$ \\
\hline $\begin{array}{l}\text { Promedio } \\
\text { ponderado }\end{array}$ & GrN-29134+ GrN-29135 & $7146 \pm 62 \quad 5$ & 5196 & $\begin{array}{l}\mathbf{6 0 6 9}-5982 \\
5941-5929\end{array}$ & $\begin{array}{l}\mathbf{0 . 9 1 9 2 1 2} \\
0.080788\end{array}$ & $\begin{array}{l}6206-6188 \\
6185-6168 \\
6163-6140 \\
\mathbf{6 1 1 0 - 5 8 9 2} \\
\end{array}$ & $\begin{array}{l}0.016068 \\
0.014274 \\
0.020743 \\
\mathbf{0 . 9 4 8 9 1 5} \\
\end{array}$ \\
\hline GrN-29861 & $\begin{array}{l}\text { Carboncillos en hogar } \mathrm{n} .{ }^{\circ} \mathrm{m} 221 \\
\text { Peso: } 9,7 \mathrm{~g} \\
\text { UE } 1450 \\
\text { Prof.: } 97 \mathrm{~cm} \\
29.06 .04 / 13.10 .05\end{array}$ & $6970 \pm 40 \quad 5$ & 5020 & $\begin{array}{l}5962-5960 \\
\mathbf{5 9 0 0 - 5 7 8 9}\end{array}$ & $\begin{array}{l}0.01816 \\
\mathbf{0 . 9 8 1 8 4}\end{array}$ & $\begin{array}{l}5977-5948 \\
\mathbf{5 9 2 1 - 5 7 4 7}\end{array}$ & $\begin{array}{l}0.098849 \\
\mathbf{0 . 9 0 1 1 5 1}\end{array}$ \\
\hline GrN-29862 & $\begin{array}{l}\text { Carbones suelo cabaña } \text { n. }^{\circ} \text { inv. } 40381 \\
\text { Peso: } 2,7 \mathrm{~g} \\
\text { UE } 1442 \\
\text { Prof.: } 135 \mathrm{~cm} \\
28.06 .04 / 13.10 .05\end{array}$ & $6940 \pm 50 \quad 4$ & 4990 & $\begin{array}{l}5877-5856 \\
\mathbf{5 8 4 9 - 5 7 5 1}\end{array}$ & $\begin{array}{l}0.151606 \\
\mathbf{0 . 8 4 8 3 9 4}\end{array}$ & $\begin{array}{l}5974-5951 \\
\mathbf{5 9 1 7 - 5 7 2 6}\end{array}$ & $\begin{array}{l}0.043451 \\
\mathbf{0 . 9 5 6 5 4 9}\end{array}$ \\
\hline $\begin{array}{l}\text { Promedio } \\
\text { ponderado }\end{array}$ & GrN-29861+ GrN-29862 & $6958 \pm 31 \quad 5$ & 5008 & 5886-5794 & 1 & $\begin{array}{l}5969-5955 \\
\mathbf{5 9 0 7 - 5 7 4 5}\end{array}$ & $\begin{array}{l}0.028521 \\
\mathbf{0 . 9 7 1 4 7 9}\end{array}$ \\
\hline
\end{tabular}

1. Las fechas más antiguas, en torno a $7150 \mathrm{BP} /$ 6000 cal BC, se han obtenido a partir de restos de los postes de sustentación de la estructura, elementos constructivos que, en buena lógica, proporcionarán una fecha más antigua que los restos terminales. Además se trata de dataciones obtenidas sobre muestras de vida larga (troncos de pino carbonizados), para los que no podemos descartar una probable reutilización en diversos momentos de la ocupación del asentamiento. En definitiva, nos indican el momento de construcción de la vivienda. Aparecen en la parte superior de la estratigrafía porque su derrumbe tendría lugar una vez abandonado el recinto.

2. Las fechas más recientes, en torno a $6950 \mathrm{BP} /$ 5820 cal BC, se han obtenido a partir de carbones recuperados en el hogar y cenizas del entorno y, por tanto, parecen un buen indicador para el final de la ocupación.

Con estos datos y teniendo en cuenta esta dinámica, el proceso de ocupación-abandono podría ser el siguiente:

a) Construcción de una cabaña con postes de madera de diámetros apreciables, acompañados de otros de menores dimensiones, diseñando una estructura cónica, datada a finales del VIII milenio BP, cubierta o protegida por pieles o por diferentes tipos de hierbas. Nos inclinamos por la primera de las posibilidades $-\mathrm{y}$ así lo hemos planteado en la reconstrucción virtualya que una cubierta vegetal hubiera proporcionado, en principio, una muestra más cuantiosa de restos polínicos y, como se puede apreciar en el correspondiente informe, la muestra fue muy escasa.

b) Ocupación de la cabaña y realización de actividades en torno al hogar central. Es difícil determinar el número de ocupaciones que se produjeron bajo esta misma estructura, sobre todo si tenemos en cuenta que estas pudieron tener un carácter estacional o temporal no muy alejado en el tiempo.

c) Abandono de la actividad y de la ocupación de la cabaña. Dataciones de inicios del VII milenio BP.

d) Deterioro de la vivienda y derrumbe de las estructuras exteriores sobre el hogar y suelo de la cabaña. Estas estructuras que estratigráficamente aparecen superpuestas a la fase c han sido datadas, pero recordemos que las muestras corresponden a los materiales de construc- 


\section{LA EXCAVACIÓN}

ción inicial de la vivienda (postes de madera datados a finales del VIII milenio BP).

e) A comienzos del VII milenio BP se produce la desocupación y el abandono. A juzgar por la pátina de algunas de las piezas analizadas en el capítulo de análisis funcional, estas debieron estar largo tiempo a la intemperie y sin grandes deslizamientos.

f) Transcurrido un tiempo difícilmente cuantificable se produciría un deslizamiento de mate- riales a lo largo de la ladera. Esto explicaría el hecho documentado de que los restos de algunas UE no se encuentren en posición primaria y aparezcan descontextualizados. Es más, como hemos comentado, algunos elementos líticos de niveles superiores pudieran pertenecer, incluso, a otras estructuras adyacentes situadas en la parte superior cuyos materiales configurarían el paquete formado esencialmente por las UE 1351, 1397 y 1398. 


\section{Estudio de materiales}

\subsection{ANÁLISIS TECNO-TIPOLÓGICO Y FUNCIONAL DE LA INDUSTRIA LÍTICA}

\section{CARLOS MAZO PÉREZ*}

El área de ocupación mesolítica excavada en el yacimiento del Cabezo de la Cruz ha ofrecido un lote de materiales líticos que alcanza casi los dos millares de restos repartidos en diferentes unidades estratigráficas. Concretamente, 1997 restos para 10 unidades, según el total proporcionado por la base de datos que hemos utilizado para registrar las características macroscópicas que resultan de una mera observación de visu. El tratamiento que se ha dado a los restos en esa base ha sido desigual. Algunos han sido registrados de manera individualizada, mientras que otros han sido tratados de forma conjunta.

\subsubsection{SOBRE TECNOLOGÍA Y TIPOLOGÍA}

\section{UE 1441, 1442 y 1449}

De las unidades 1441, 1442 y 1449 (en adelante serie 1400), que se corresponden con un fondo de cabaña, proceden 681 restos líticos, todos en sílex, que se distribuyen de la siguiente manera: 8 restos tipologizables $(1,17 \%)$, un núcleo de lascas $(0,15 \%), 10$ lascas $(1,47 \%), 17$ láminas $(2,50 \%)$, 63 lasquitas $(9,25 \%), 139$ laminitas y microlaminitas $(20,41 \%), 394$ debris $(57,86 \%), 37$ saltados térmicos $(5,43 \%), 6$ chunks $(0,88 \%)$ y 4 láminas de cresta y 2 avivados $(0,88 \%)$ (fig. 1$)$. En total, suponen 402,2 g de sílex, de los que las piezas tipologizables representan $1,8 \mathrm{~g}(0,44 \%)$, las lascas $62,4 \mathrm{~g}$, las láminas $45,4 \mathrm{~g}$ y el núcleo $11,7 \mathrm{~g}$. El sílex es de muy buena calidad y procede de las inmediaciones, en el entorno del río Huerva (zona de

\footnotetext{
* Área de Prehistoria, Dpto. de Ciencias de la Antigüedad, Universidad de Zaragoza.
}

Botorrita, Muel, Jaulín). Se han reconocido algunas alteraciones, de la que la más representada es la pátina, con 335 casos $(49,33 \%)$, a veces, acompañada de desilificación, alteración que se registra en 51 casos $(7,48 \%)$. También, hay ejemplos de alteración térmica, aunque posiblemente la observación de visu no refleje la realidad del número de restos afectados. A simple vista, se han registrado 29 casos de levantamientos térmicos, 15 más con craquelados y cuarteados y 2 rubefactadas.

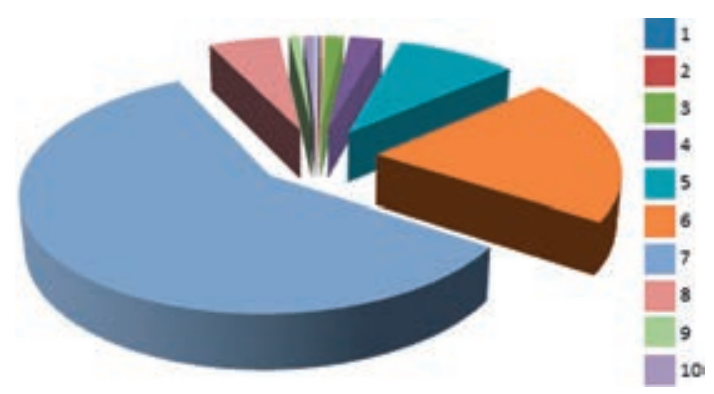

Figura 1. 1. Piezas tipologizables; 2. Núcleos; 3. Lascas; 4. Láminas; 5. Lasquitas; 6. Laminitas y microláminas; 7. Debris; 8. Saltados térmicos; 9 Chunks; 10. Láminas de cresta y avivados.

\section{UE 1351,1397 y 1398}

Las unidades 1351, 1397 y 1398 (en adelante, serie 1300) representan, según los directores de la excavación, un episodio en la evolución del yacimiento en el que estas unidades, situadas topográficamente a una cota superior en la ladera del yacimiento que las correspondientes al fondo de cabaña, deslizarían sobre estas cubriéndolas. En ellas se han recuperado 1065 restos líticos de sílex, que se distribuyen de la siguiente manera: 26 restos tipologizables $(2,44 \%), 3$ núcleos de lascas $(0,28 \%), 29$ lascas $(2,72 \%), 37$ láminas $(3,47 \%), 115$ lasquitas $(10,79 \%), 149$ laminitas y microlaminitas $(13,99 \%), 640$ debris $(60,09 \%)$, 43 saltados térmicos $(4,03 \%), 2$ chunks $(0,18 \%)$, 
9 flancos de núcleo $(0,84 \%)$, 4 láminas de cresta y 7 avivados (1,03\%) (fig. 2). En total suponen $1104,04 \mathrm{~g}$ de sílex, de los que las piezas tipologizables representan 10,2 g $(0,92 \%)$, las lascas 136,7 g, las láminas 107 g y los núcleos 309 g. Se han reconocido también alteraciones, de las que la pátina es la más representada, afectando a 618 restos $(58,02 \%)$, a veces acompañada de alguno de los 28 casos de desilicificación $(2,62 \%)$. Igualmente hay ejemplos de alteración térmica: 39 quemadas y/o craqueladas $(3,66 \%), 31$ con levantamientos térmicos $(2,91 \%)$ y 4 rubefactadas $(0,37 \%)$. Además se han recuperado dos cantos de cuarcita, uno de ellos con claras marcas de haber sido utilizado como percutor.
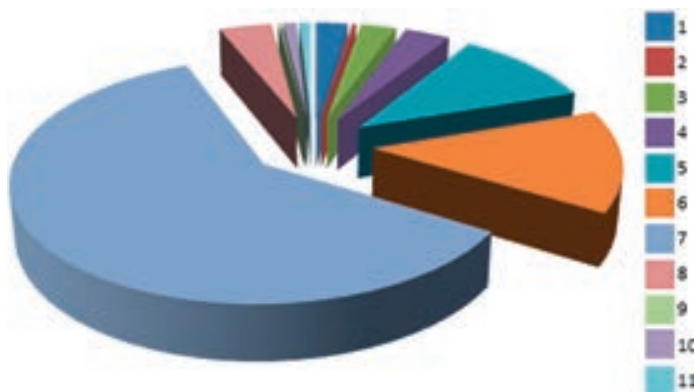

Figura 2. 1.Piezas tipologizables; 2. Núcleos; 3. Lascas; 4. Láminas; 5. Lasquitas; 6. Laminitas y microláminas;

7. Debris; 8. Saltados térmicos; 9 Chunks; 10. Láminas de cresta y avivados; 11. Flancos de núcleo.

El comportamiento de ambas series de unidades es básicamente similar, como puede observarse en la figura 3. La representación de núcleos y otros elementos (láminas de cresta, flancos de núcleo) relacionados con los procesos con formación y avance en su explotación es algo mayor en las unidades de la serie 1300, y aunque estos últimos están asociados a la explotación in situ de núcleos de láminas o laminitas, los núcleos destinados a la obtención de este tipo de soportes no aparecen representados directamente, ya que todos los hallados corresponden a la extracción de lascas. Muy pocos son también los soportes de formato laminar y módulo medio o mayor (aquellos en los que mejor se podría indagar este asunto relativo a la estrategia de explotación) correspondientes a los órdenes 1 y 2 . En el caso de la serie 1400 (la correspondiente al fondo de cabaña), de las 17 láminas, 16 son de orden 3 y una de orden 2. En la serie $1300,31(83,78 \%)$ de las 37 son de orden 3 , $5(13,51 \%)$ de orden 2 y una $(2,70 \%)$ de orden 1 . La ausencia de núcleos de láminas, la escasa representación de productos de acondicionamiento propios de la cadena operativa de explotación de ese tipo de núcleos, y también la baja presencia de soportes de orden 1 y 2 entre las láminas (que sí aparecen algo más representados en el caso de los formatos de tipo lasca), apuntan en la dirección de un proceso de obtención de estos soportes fuera de este espacio, pero no sabemos si fuera del yacimiento o fuera del área que se excavó. Consideramos que no es sino conjetura aventurar a partir de estas evidencias si la estrategia de explotación implicó el desarrollo de la cadena operativa en el lugar, o solo parte de ella, dado que el yacimiento fue excavado parcialmente.

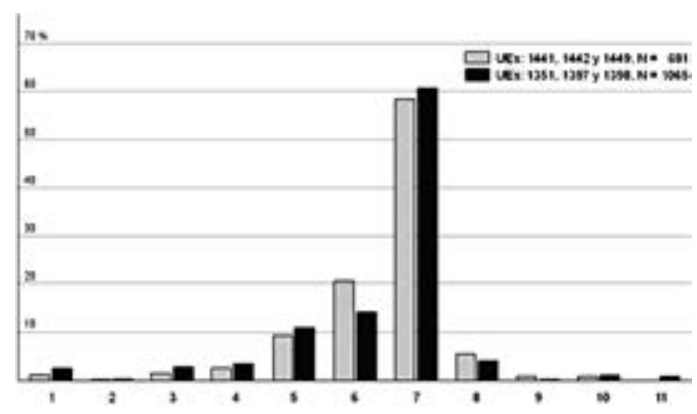

Figura 3. 1.Piezas tipologizables; 2. Núcleos; 3. Lascas; 4. Láminas; 5. Lasquitas; 6. Laminitas y microláminas; 7. Debris; 8. Saltados térmicos; 9. Chunks; 10. Láminas de cresta y avivados; 11. Flancos de núcleo.

Tampoco difieren las series en su grado de afectación por las alteraciones térmicas, buena parte de las cuales tienen claramente su origen en la exposición a una fuente de calor. En el caso de la serie 1400 la relación entre restos craquelados, quemados, rubefactados o con saltados térmicos de superficies rugosa y las estructuras de combustión del fondo de cabaña parece claramente evidente, mientras que en la otra serie el origen necesariamente tendría que ser el mismo, aunque las unidades no han aparecido asociadas a ese tipo de estructuras in situ. Hemos dicho ya que la presencia de alteraciones térmicas debidas al fuego ha de ser mayor que los efectivos computados de visu, porque, efectivamente, durante la observación microscópica se han registrado piezas con claras evidencias de craquelados que no resultaban visibles a simple vista. Otras alteraciones térmicas, en forma de levantamientos elipsoidales de superficie lisa también se reconocen, al igual que se observan hoy en día entre los nódulos y fragmentos de sílex que se encuentran en las terrazas del río Huerva, y que son saltados naturales producidos por la exposición de este material a bajas temperaturas. La exposición de los materiales de 
ambas series a condiciones subaéreas durante un tiempo tal vez prolongado en condiciones de «estabilidad» es una posibilidad que vendría avalada por ese tipo de saltados, pero sobre todo por la distribución de la pátina en las piezas (Borrazzo 2004). La pátina es la alteración más ampliamente representada en estos conjuntos, afectando al $49,33 \%$ de los restos de la serie 1400 y al $58,02 \%$ de la serie 1300 . Una circunstancia que ha sido observada aunque no se ha cuantificado porque se ha reparado en ella a posteriori es que un buen número de las piezas con pátina ofrecen una distribución desigual de la alteración entre las caras. Esa expresión diferencial de este tipo de meteorización podría utilizarse, en la línea planteada por Borrazzo, como indicador tafonómico de estabilidad. La pátina sobre una de las superficies de las caras total o parcialmente indicaría una situación de «mayor estabilidad».

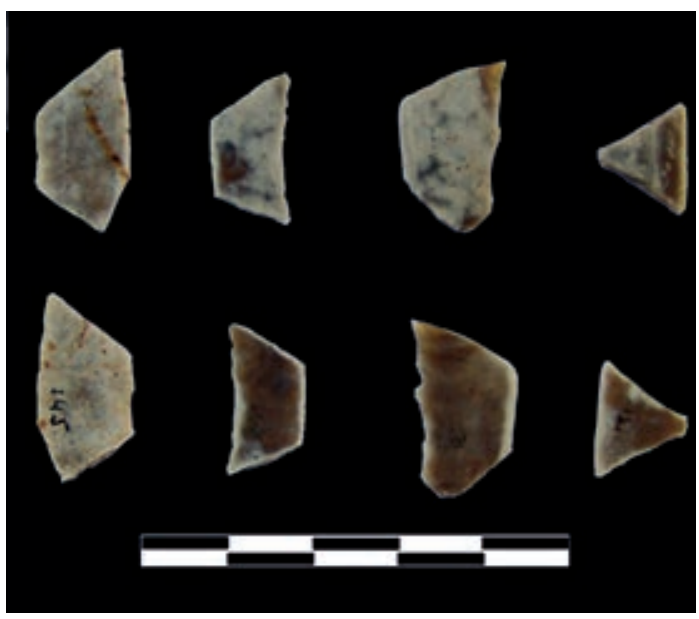

Figura 4. Geométricos. Fila de arriba, vista de la cara dorsal. Fila de abajo, vista de la cara ventral.

En la figura 4, vemos las combinaciones observadas en cuanto a la distribución de la pátina sobre las piezas que presentan esta alteración. La de la izquierda, que está afectada por una pátina completa por ambas caras, la de la derecha, con una pátina de desarrollo variable también por ambas caras, y las dos del centro, con una cara patinada y la otra no. Son estos casos, que además son numerosos, los que nos llevan a pensar que el conjunto estuvo en condiciones subaéreas de estabilidad durante un tiempo antes de quedar sepultado por el sedimento.

El total de restos tipologizables en la serie 1300 asciende a 26 efectivos, todos ellos en sílex, repartidos de la siguiente manera:
- Raspador sobre lámina o laminita retocada, 1

- Fragmento de lámina con borde abatido, 5

- Laminita apuntada con borde abatido, 3

- Laminita con borde abatido parcial, 2

- Fragmento de laminita con borde abatido, 6

- Lámina o laminita con muesca, 1

- Pieza con fractura retocada, 1

- Trapecio simétrico, 7

- Triángulo isósceles, 1

A estas piezas podrían añadirse cuatro soportes (dos lascas, una lámina y otro fragmento de sílex) que presentan retoques simples marginales.

En la serie 1400 los restos tipologizables, también todos en sílex, son 8 :

- Fragmento de lámina con borde abatido, 3

- Laminita con borde abatido arqueado, 1

- Laminita con borde abatido parcial, 1

- Fragmento de laminita con borde abatido, 2

- Trapecio asimétrico, 1

Además, una lasca presenta retoque simple marginal.

El total de efectivos retocados del yacimiento se completa con una laminita apuntada con borde rectilíneo y base redondeada, procedente de la unidad 1438, y un buril simple múltiple de la unidad estratigráfica 1000, en la que también hay una lasca con retoque simple marginal.

\subsubsection{ANÁLISIS FUNCIONAL}

La observación microscópica tenía por objeto el reconocimiento de huellas tecnológicas y funcionales; las típicas que se relacionan en cualquiera de los trabajos de este tipo y que se conocen bien desde los años setenta y ochenta del pasado siglo (Keeley 1980; Mansur 1983; Moss 1983; Plisson 1985; Vaughan 1985; Mazo 1989, etc.), y los medios técnicos empleados para la observación de las mismas han sido una lupa binocular de cámara clara (Nikon SMZ-10) con un rango de magnificación de 6.6 hasta 40x, con una fuente de iluminación externa de luz fría (Intralux 5000-1) y un microscopio metalográfico (Nikon Optiphot) que permite manejarse entre los 40 y 1000x, aunque las piezas han sido observadas habitualmente a 100 y $200 x$.

El registro fotográfico se ha realizado con una cámara analógica (Nikon FX35) que puede utilizarse con ambos aparatos y un módulo de control y disparo (Nikon AFX-II). La película utilizada ha sido la Ilford en blanco y negro HP5 Plus 400. También hemos utilizado, por primera vez, dos 
cámaras digitales (5 Mpx) para ocular de microscopio de la gama Poli-eye, de Qualites.net; una para el microscopio, para oculares de diámetro interior de $23 \mathrm{~mm}$ (PL-SM055-5) y otra para la lupa, con un diámetro interior del ocular de $30 \mathrm{~mm}$ (PL-SM055C-5). Estas cámaras se conectan a través de un puerto USB a un ordenador, en el que se visualiza y captura la imagen mediante su correspondiente software, DinoCapture 2.0. en este caso.

Cada una de las piezas se ha conservado desde el momento en el que se recuperaron en bolsas separadas y alguna de ellas presenta una signatura recubierta de barniz. En estos casos el barniz fue eliminado con acetona y la limpieza general de las mismas y eliminación de la grasa de los dedos, como consecuencia de su manipulación, se realizó con agua y jabón.

El análisis funcional se ha efectuado sobre 16 de las 34 piezas tipologizables de las series 1300 y 1400 y sobre una pieza de la unidad 1438, que aparecen en las láminas 2 y 3.

En la figura 5, aparecen los geométricos que han sido objeto de análisis de huellas de uso. De izquierda a derecha y de arriba abajo, les corresponden las siglas 13341 (UE 1351), 40081 (1398),
40175 (1398), 13158 (1351), 13204 (1351), 13253 (1351), 40261 (1441) y 12728 (1351). Algunos aspectos de carácter macroscópico que pueden apuntarse son la presencia de alteraciones térmicas en las piezas 2 y 7 , que han producido afecciones intensas. En la pieza 2, por ejemplo, los craquelados han llegado incluso a hacer saltar pedazos y en la 8 se han producido igualmente roturas y saltados térmicos. Puede verse también la afección de la pátina y la presencia muy clara en la pieza 5 de recrecimientos de óxido, también presentes en la 1 y en la 4 .

La figura 6 reúne el lote de laminitas de dorso apuntadas, en algún caso completas, que han sido analizadas. Siguiendo el mismo orden, les corresponden las siglas 40889 (UE 1449), 40953 (1438), 40513 (1442), 13067 (1351), 13075 (1351), 12726 (1351), 40288 (1441), 12724 (1351) y 40625 (1442). A simple vista no se reconoce entre ellas más alteración que la pátina, sin embargo, en las láminas 4 y 5 puede verse, como ejemplo de lo que hemos apuntado anteriormente, que a nivel microscópico sí se aprecia la existencia de alteración térmica. Ese nivel de alteración es sugestivo de un contacto directo con una fuente de intenso calor.

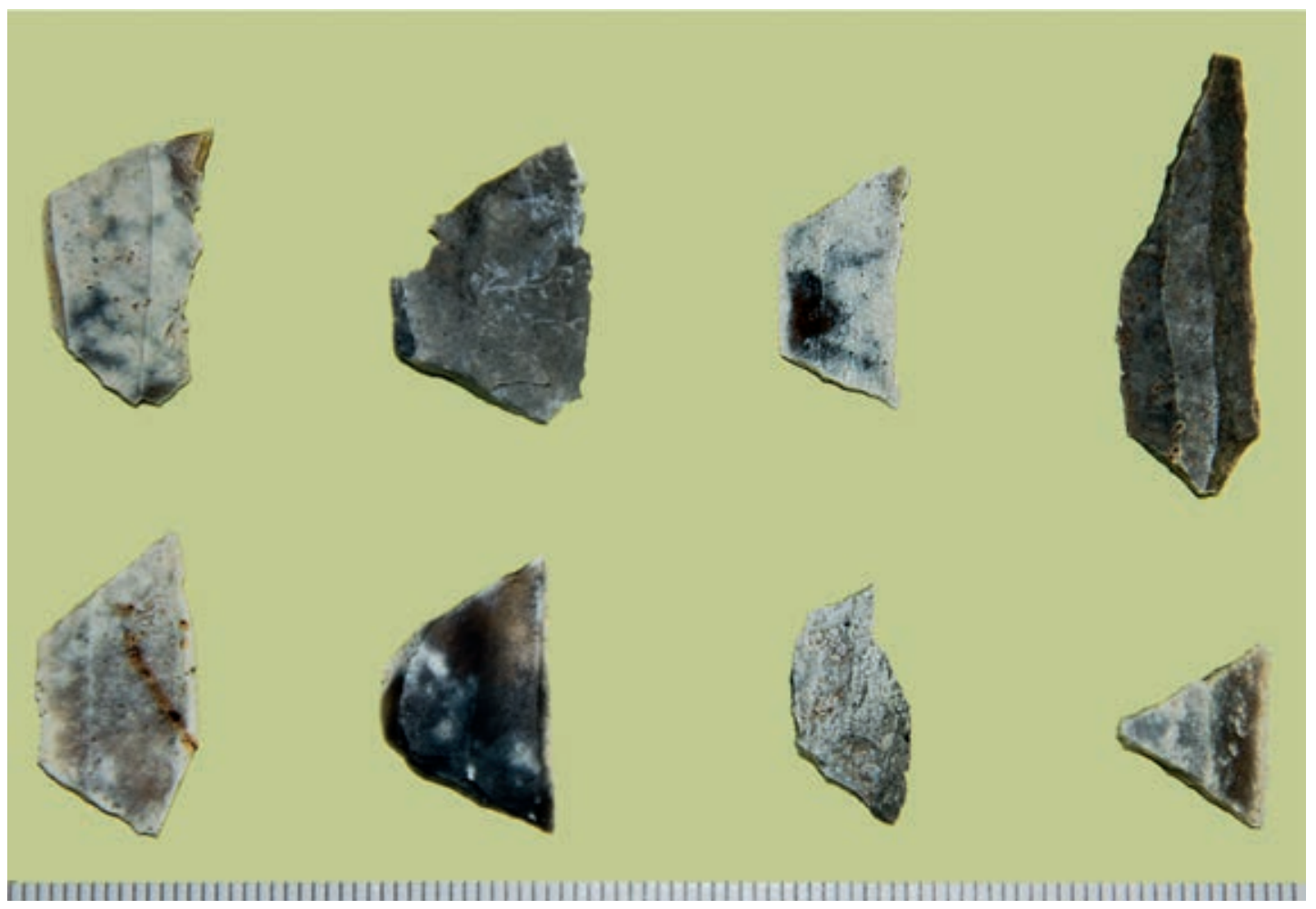

Figura 5. Geométricos. 
CARLOS MAZO PÉREZ. Análisis tecno-tipológico y funcional de la industria lítica
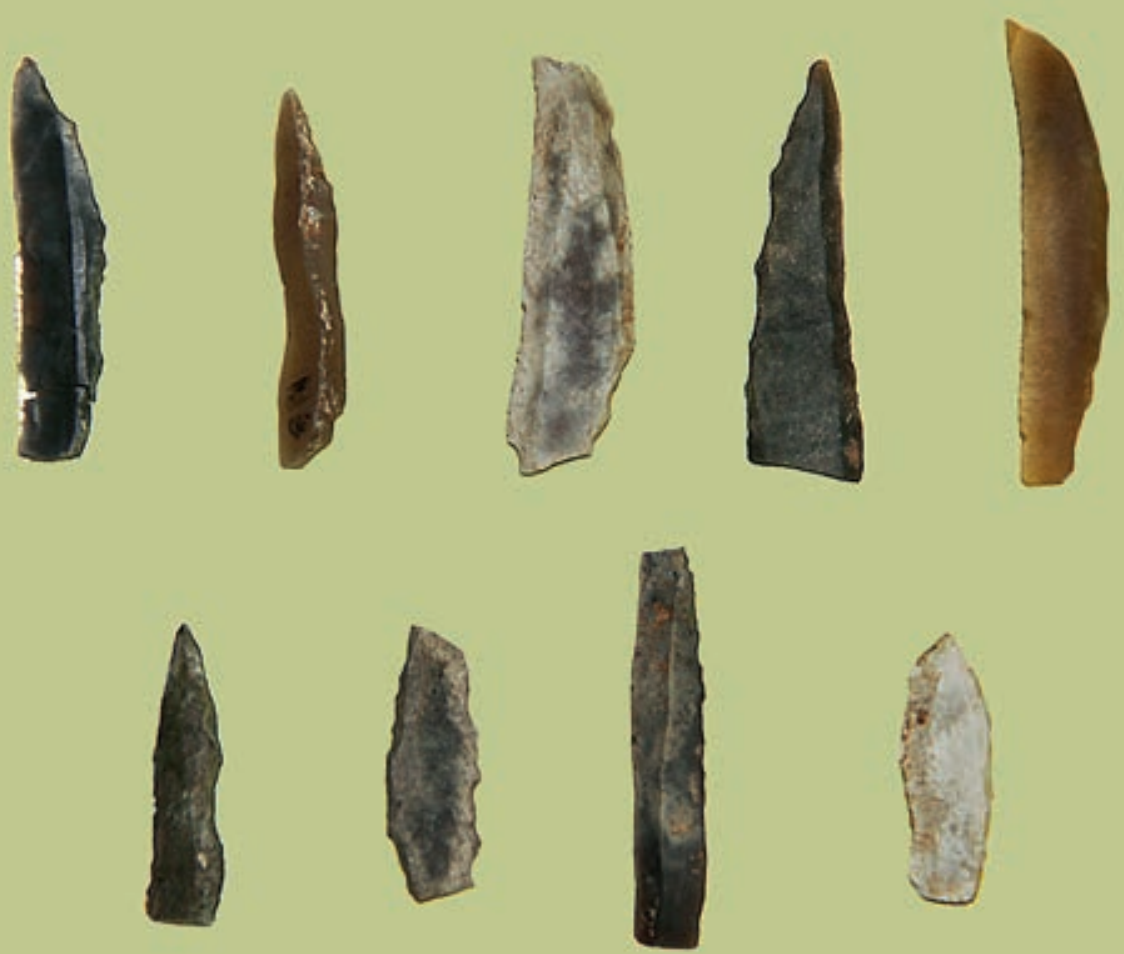

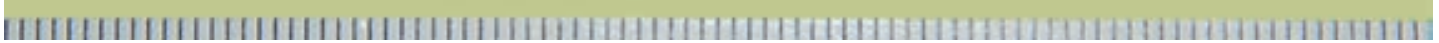
Figura 6. Laminitas de dorso apuntadas.

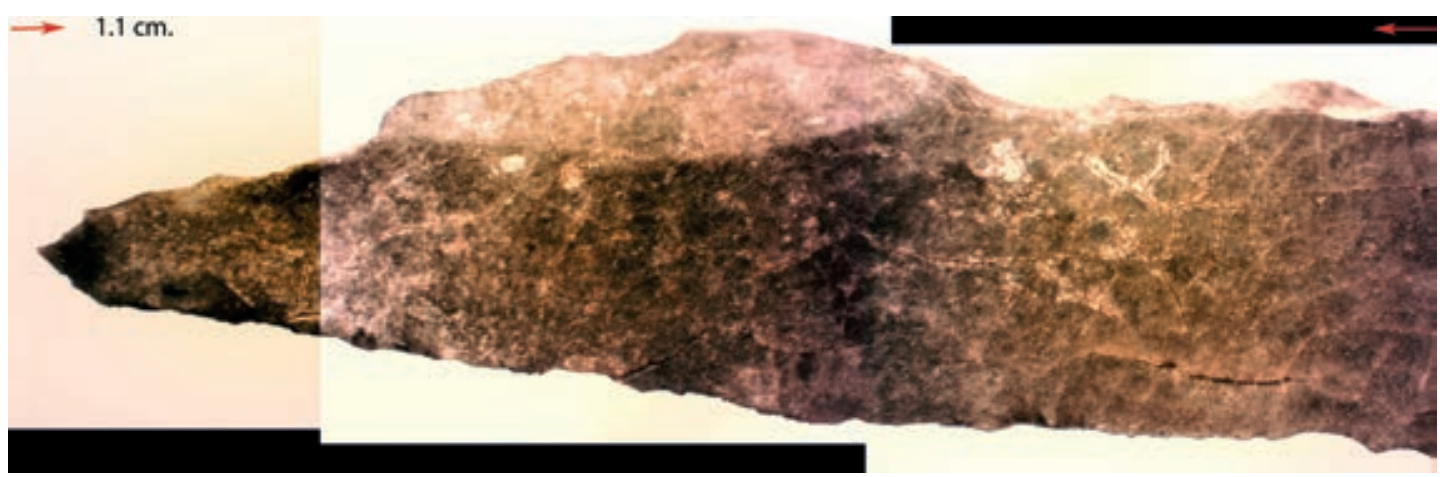

Figura 7. Pieza 12726 (UE1351). Cuarteada por fuego.

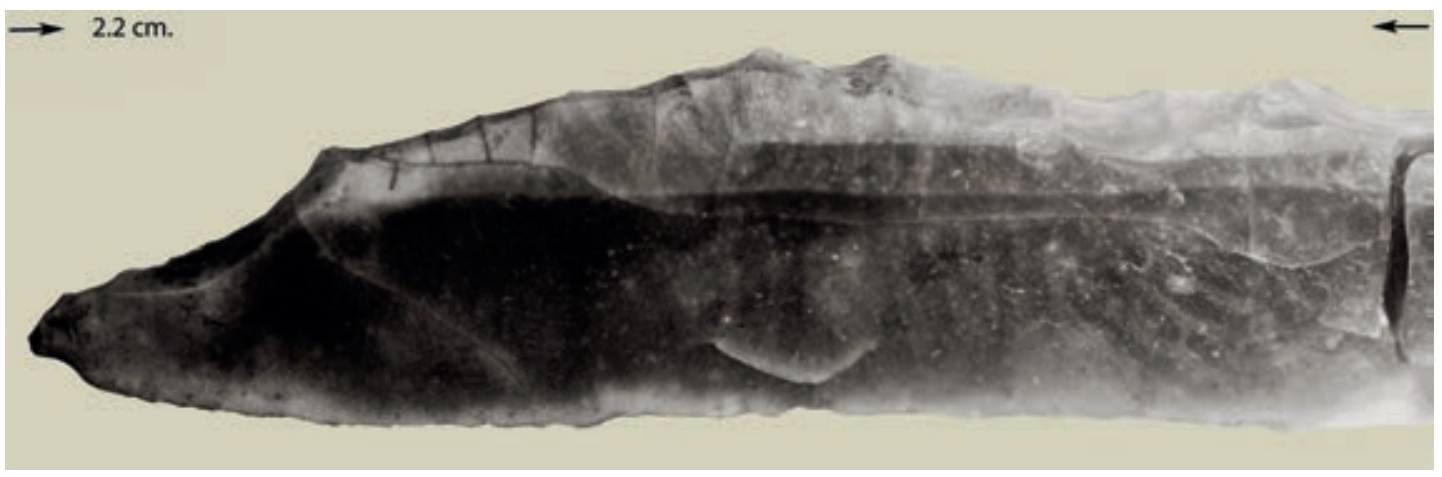

Figura 8. Pieza 40889 (UE1449). Cuarteada por fuego. 
El análisis microscópico de estas piezas ha tenido como objeto el reconocimiento de huellas laborales suficientemente diagnósticas como para proponer una interpretación funcional (Mazo 1997). En ese análisis también se han reconocido huellas tecnológicas, derivadas del proceso de producción de las piezas (fig. 9) y otras originadas tras su recuperación. En casi todas las observadas hay rastros metálicos y también de grafito. Las huellas laborales significativamente más diagnósticas a la hora de una interpretación funcional son los micropulidos, y las estrías que, en ocasiones, se asocian a ellos, por encima de otros rastros de carácter exclusivamente mecánico. Sin embargo, en este caso, como ocurre en otros estudios, se han registrado pocas huellas de ese tipo.

La razón tiene que ver, por una parte, con el estado de conservación de las piezas que no permite la mayoría de las veces una buena observación. En términos generales todas tienen un alto grado de reflectividad, generada no solo por una presencia variable de la pátina sino también por el considerable desarrollo de lustre de suelo que presentan. El lustre de suelo, que nosotros entendemos que es una redisolución de la sílice superficial que en su grado de mayor desarrollo puede llegar a colmatar pequeñas cavidades de la microtopografía del sílex y fisuras como las producidas por la percusión (fig. 9), genera una película que actúa a modo de velo y que aumenta de forma importante la reflectividad de la pieza.

Por otra parte, está la cuestión del propio destino laboral de las piezas, en el sentido de que, de la misma manera que todos los tipos de sílex no registran con la misma rapidez en su grado de desarrollo el micropulido producido por una materia

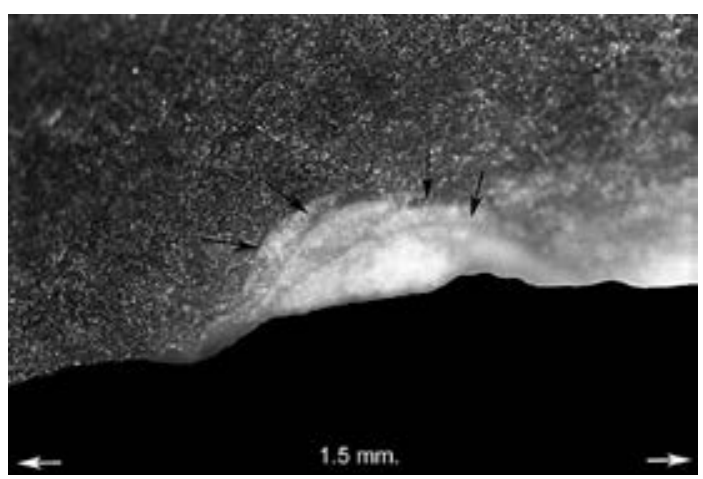

Figura 9. Fracturas producidas en el proceso de retoque de un filo mediante percusión. El impacto genera una fractura sin que llegue a desprenderse la microlasca. Pieza 40953 (UE 1438). dada, tampoco esas variables se comportan de la misma manera en función de las actividades y/o materias procesadas. Los estudios que se han realizado sobre la funcionalidad de las puntas dorso y de los geométricos en nuestro entorno geográfico otorgan a estas piezas un uso mayoritario como elementos de proyectil (Palomo y Gibaja 2001; Gibaja 2002; Domingo 2003, 2005 y 2008; Laborda 2010; Rodríguez 2011), mientras que otros usos quedan muy lejos de este porcentualmente hablando. Así se constata en la serie más amplia estudiada (Domingo 2008), con más de 600 efectivos procedentes de distintos yacimientos del valle del Ebro. Esos usos minoritarios se reconocen bien precisamente a través de la presencia de micropulidos (Domingo 2008, lám. IV), pero, cuando la interpretación es como elemento de proyectil, los micropulidos aparecen poco y una razón puede ser el tipo de materia sobre el que se actúa y la fugacidad de la acción, en la que si no media un «accidente» (en forma de impacto con un hueso, por ejemplo) puede no reconocerse ningún indicio de uso.

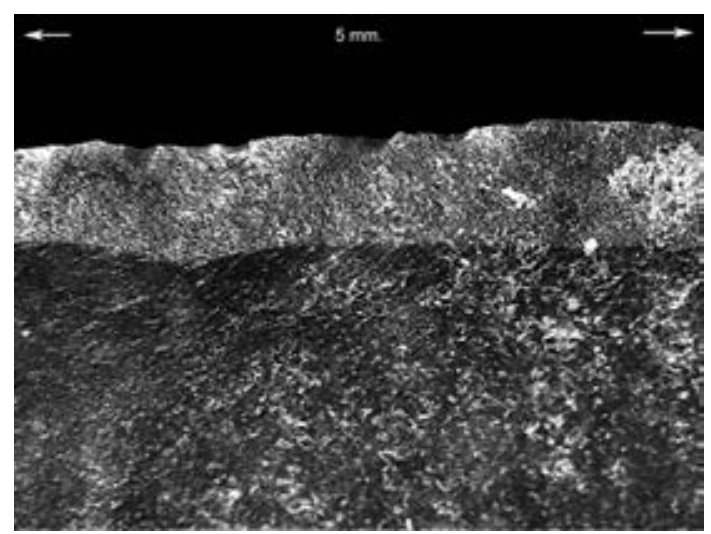

Figura 10. Microesquilarmientos de terminación limpia y también de fractura seca en el borde no retocado de una punta de dorso. Pieza 40513 (UE 1442).

Así, en esas condiciones, el peso en la interpretación funcional recae, y en este caso también ha sido así, sobre indicadores como plataformas de abrasión (surcadas por estrías), microesquirlamientos y fracturas, todos ellos de origen mecánico. El grado de confianza en este tipo de indicadores no es el mismo, porque es evidente que el comportamiento mecánico del sílex ofrece una respuesta convergente a acciones iguales aunque de origen distinto. La presión generada por el pisoteo puede producir microesquirlamientos difícilmente distinguibles de los que produce la presión 
del útil sobre el material trabajado; o un choque accidental entre piedras puede producir una plataforma de abrasión con estrías como la que produce un percutor o el roce de un fragmento del propio útil desprendido por un impacto. De esos tres indicadores, el menos competente es el de los esquirlamientos producidos en los filos (fig. 10).
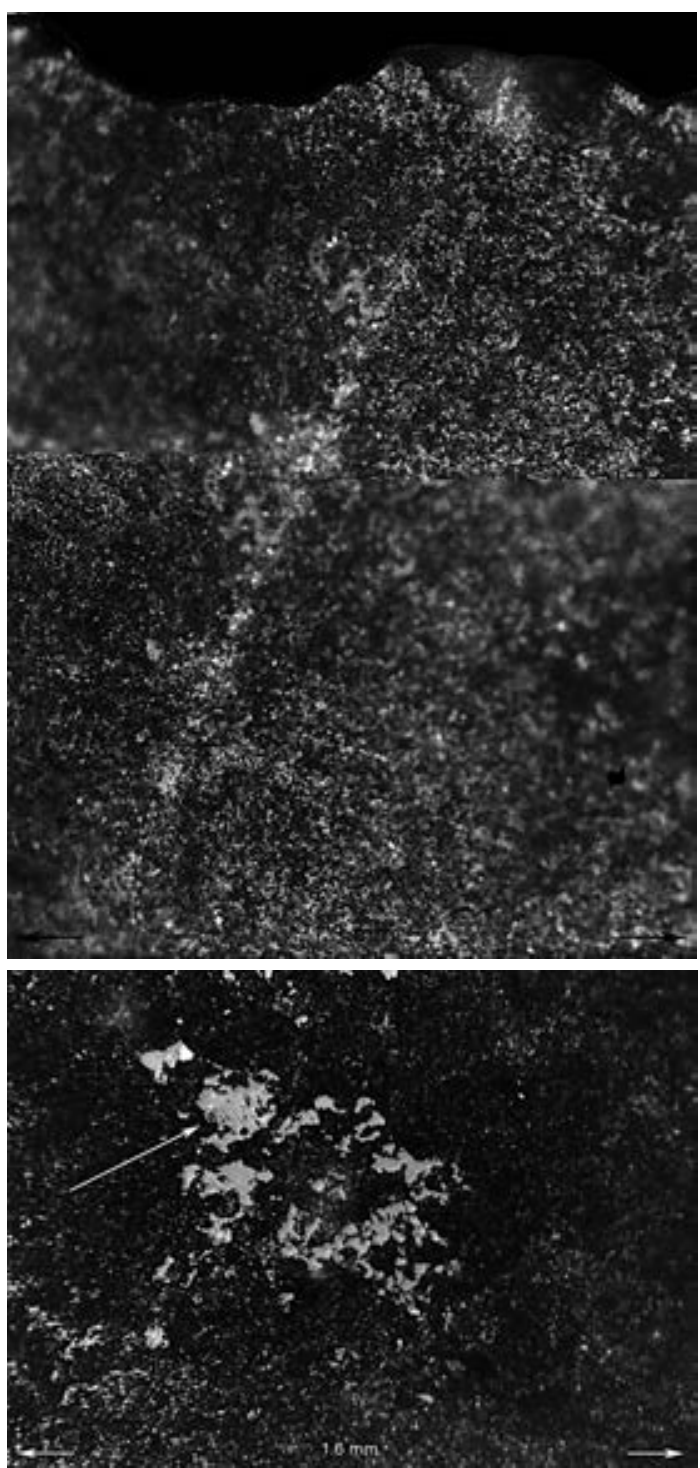

Figuras 11 y 12. Abrasión lineal en un borde asociada a un microsaltado. Pieza 40953 (UE 1438). Intensa plataforma de abrasión en el interior de una pieza en la que se reconocen estrías. Pieza 13075 (UE 1351).

Con respecto a los otros indicadores, hay un mayor grado de fiabilidad. En el caso de las plataformas es importante su localización (aunque no siempre) y la asociación con saltados si se da en
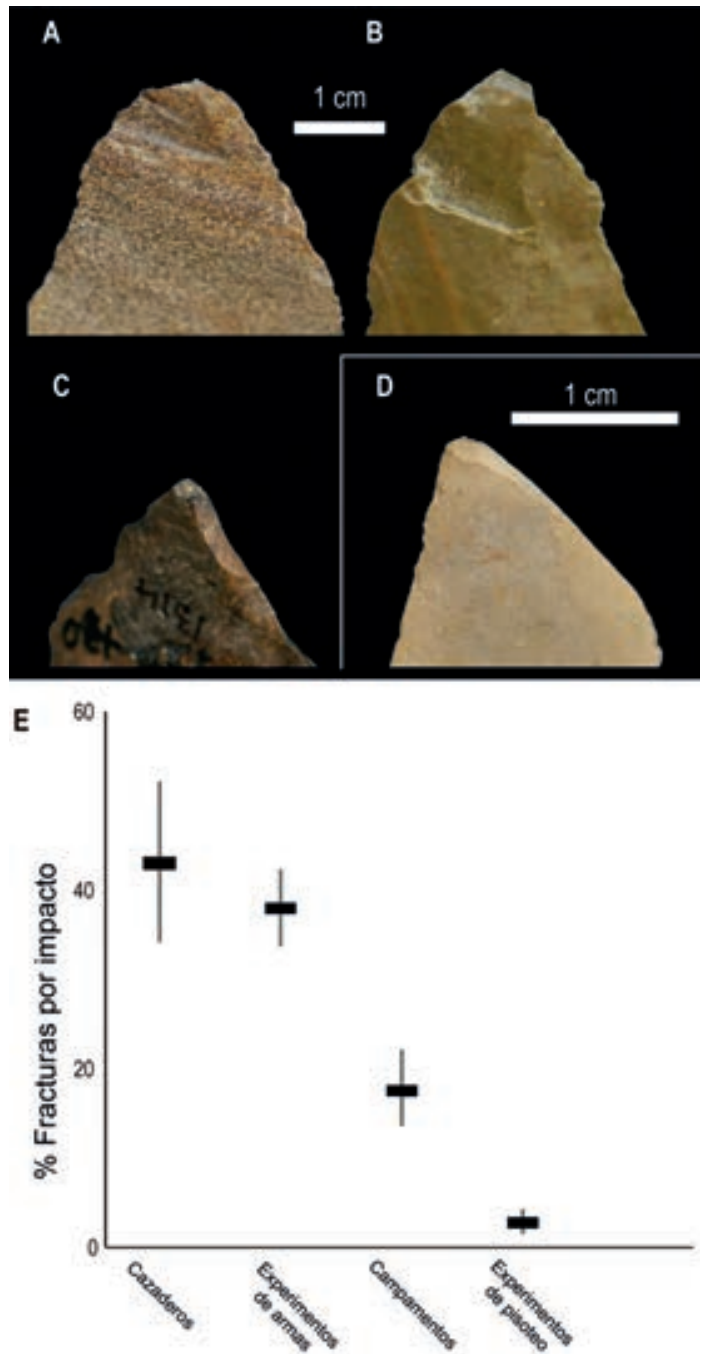

Figura 13. Fracturas complejas asociadas a un uso de las piezas como proyectil. Gráfica de frecuencias en distintos tipos de yacimientos (Adaptado de Wilkins et al.2012).

un borde (láms. 8 y 9), mientras que, en lo que respecta a las fracturas, es determinante su tipología (Fischer et al. 1984; Pelegrin y O'Farrell 2005). La aparición de fracturas complejas en extremos, bases o bordes se ha registrado en experimentos en los que se han empleado piezas como proyectiles impactando sobre presas, y su presencia en conjuntos arqueológicos implica que los artefactos fueron empleados como tales. La aparición de fracturas similares también puede resultar de procesos postdeposicionales, aunque su frecuencia dentro de los conjuntos se ha considerado más baja (Pargeter 2011).

En la figura 13, se pueden ver varios tipos de fracturas consideradas diagnósticas del uso como 
proyectiles de las piezas, así como su frecuencia en distintos tipos de yacimientos según aportan Wilkins et al. (2012).

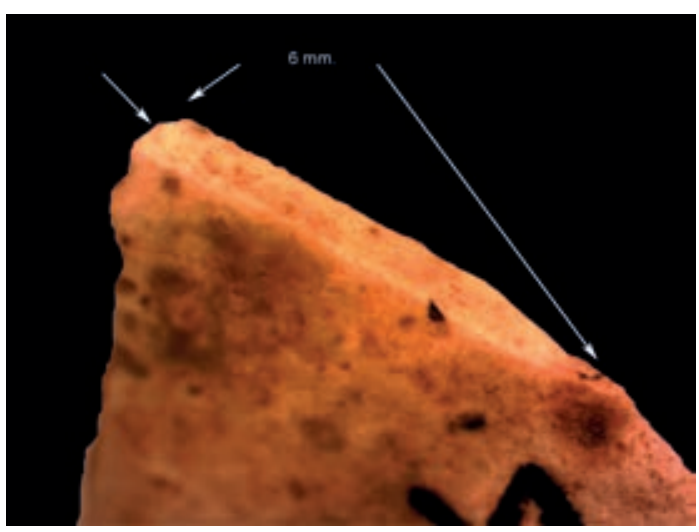

Figura 14. Fractura compleja de tipo burilante registrada en la pieza 13204 (UE 1351). La presencia de este tipo de fracturas se asocia a la utilización de la pieza como proyectil.

Aparte de plataforma de abrasión y fracturas, también se han registrado a nivel microscópico el redondeamiento de salientes y esconces de algunos dorsos junto con la presencia de áreas abrasionadas y micropulidos que tanto por su extensión como por su localización se han considerado evidencias de enmangue (fig. 16). En algunos casos se ha registrado la presencia en esas mismas zonas de puntos rojos por debajo del velo generado por el lustre de suelo, sin que podamos indicar si se trata de restos de ocre o de algún elemento mineral que forme parte de la propia composición del sílex.

\section{Resultado del análisis}

No hemos realizado para este análisis un protocolo experimental propio que nos sirva de referencia, pero consideramos que contamos con información suficiente para abordar el estudio. En primer lugar, porque conocemos bien el comportamiento de este sílex, del área de Muel-BotorritaJaulín, con el que venimos trabajando en otras colecciones experimentales, con otras tipologías de artefactos, desde hace mucho tiempo, y, en segundo lugar, porque en la última década se ha realizado un importante trabajo experimental, por parte de otros investigadores, sobre todo en lo que se refiere a los geométricos que ha sido muy precisamente publicado (Palomo y Gibaja 2001; Gibaja 2002; Domingo 2003, 2005, 2008). Con el propio Rafael Domingo hemos tenido una relación muy estrecha en esa investigación.
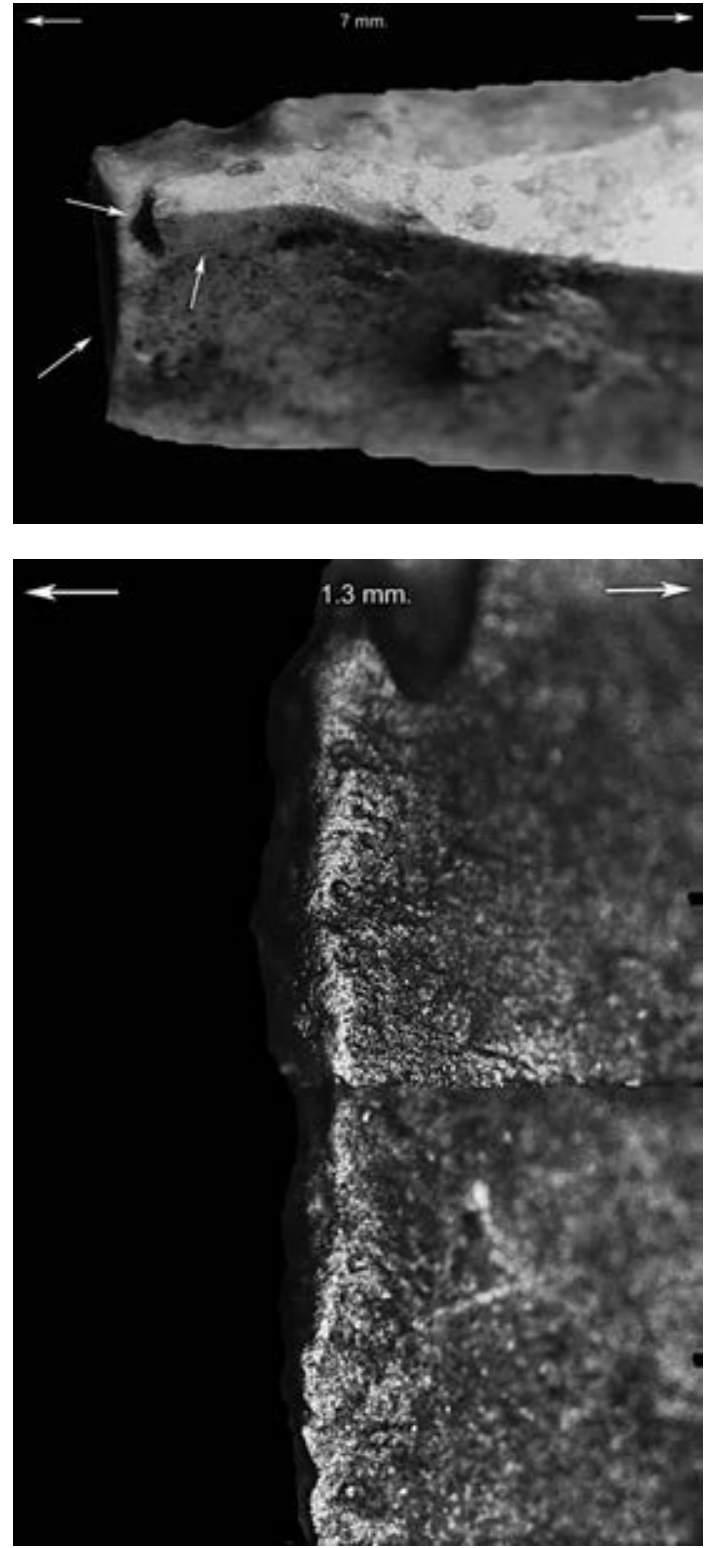

Figuras 15 y 16. Fractura por flexión. Pieza 12724 (UE1351). Redondeamiento de un dorso con área de micropulido considerado resultado del enmangue de la pieza. Pieza 13075 (UE 1351).

\section{Trapecios}

13158. Trapecio simétrico alargado con retoque abrupto sobre sílex de grano fino a muy fino, de color marrón, escasamente patinado sobre el filo largo no retocado. Se encuentra roto. L.: $33 \mathrm{~mm}$, A.: $11 \mathrm{~mm}$; E.: $3 \mathrm{~mm}$. Peso: 0,7 g. A pesar de su apariencia, la observación al microscopio es muy mala. Presenta algunos puntos que posiblemente se corresponden con óxido de hierro en la zona ventral del lado retocado mejor conservado, y también acusado redondeamiento en la zona de 
paso al lado corto retocado. Posiblemente ambos hechos pueden estar relacionados con la circunstancia de que pueda ser el área del enmangue. El lado más largo retocado termina en una fractura seca de dimensiones muy reducidas. Como hecho más significativo presenta una fractura burilante en el otro extremo del lado largo no retocado y posiblemente restos de micropulido junto a la rotura, pero la observación ahí es muy mala. La pieza se considera usada como proyectil.

13341. Trapecio simétrico con retoque abrupto sobre sílex de grano fino a muy fino, de color marrón caramelo. Se encuentra roto. L.: $21 \mathrm{~mm}$; A.: 13 mm; E.: 2 mm. Peso: 0,5 g. Presenta pátina muy desarrollada de color blanco-amarillento en la cara dorsal, en tanto que en la ventral solo se ha desarrollado en forma de estrecha banda junto a los bordes. Al microscopio la observación es muy mala, con intenso lustre de suelo. Algunos recrecimientos de óxido en la cara dorsal y puntos tal vez de ocre en la cara ventral, desde la mitad del lado largo no retocado hasta el lado retocado que mejor se conserva, por el que también se distribuyen. Presenta como el anterior fractura burilante que afecta a un extremo (el contrario) del lado largo no retocado. Hay dos saltados importantes de origen incierto, inversos, afectando a ese mismo borde. Podrían haberse generado a la vez que la fractura, aunque esto, en realidad, no es importante a la hora de determinar que la pieza se considera usada como proyectil.

13204. Trapecio simétrico con retoque abrupto sobre sílex de grano fino a muy fino con una densa capa de pátina de color blanco-amari1lento. Se encuentra roto. L.: $23 \mathrm{~mm}$; A.: $12 \mathrm{~mm}$; E.: $2 \mathrm{~mm}$. Peso: 0,5 g. Ya a simple vista se observan recrecimientos de óxido en ambas caras. Queremos llamar la atención sobre el hecho de que la distribución es prácticamente idéntica a la observada para los recrecimientos y restos de posible ocre en el trapecio anterior, con la diferencia de que en este caso se aprecia en ambas caras. Y en ambas caras la distribución es coincidente, y quedaría marcada por la línea que se aprecia en la cara dorsal (fig. 5), es decir, desde el lugar en el que acaba la fractura burilante hasta prácticamente la mitad del lado retocado que se conserva completo. No preguntamos si no podría corresponderse con la zona enmangada. La observación al microscopio es muy mala. Es claramente visible una fractura burilante (fig. 14), localizada en el mismo punto que en los trapecios anteriores, es decir, en un extremo del lado largo no retocado y también un notable microesquirlamiento del borde bruto más largo. La pieza se considera usada como proyectil.

40175. Trapecio simétrico con retoque abrupto, sobre sílex marrón intensamente patinado de blanco-amarillento por la cara dorsal, en tanto que por la ventral la pátina se reduje a una banda de apenas un milímetro a lo largo de todo su perímetro. Está completo. L.: $19 \mathrm{~mm}$; A.: $8 \mathrm{~mm}$; E.: $3 \mathrm{~mm}$. Peso: 0,3 g. Muy mala observación. A la pátina añade intenso lustre de suelo. Hay huellas metálicas. No se aprecian huellas de uso.

40261. Trapecio simétrico con retoque abrupto sobre sílex. Se encuentra roto. L.: $17 \mathrm{~mm}$; A.: $9 \mathrm{~mm}$; E.: $2 \mathrm{~mm}$. Peso: 0,3 g. Presenta una intensísima alteración térmica. Se encuentra quemado y con numerosos saltados de superficie rugosa. No se puede apuntar ningún dato sobre su posible utilización.

40081. Trapecio simétrico con retoque abrupto sobre sílex. Se encuentra completo aunque fragmentado. L.: $21 \mathrm{~mm}$; A.: $16 \mathrm{~mm}$; E.: $4 \mathrm{~mm}$. Peso: $0,9 \mathrm{~g}$. Presenta una intensísima alteración térmica. Se encuentra quemado y cuarteado. No se puede apuntar ningún dato sobre su posible utilización.

13253. Trapecio simétrico con retoque abrupto sobre sílex de grano fino a muy fino, de color marrón oscuro. Presenta una banda de pátina blanco-amarillenta a lo largo de todo el perímetro y algunas áreas menos intensas en el interior de la cara dorsal. Se encuentra completo. L.: $21 \mathrm{~mm}$; A.: 13 mm; E.: 3 mm. Peso: 0,6 g. Presenta una pequeña fractura burilante en un extremo del lado largo no retocado pero es difícil pronunciarse sobre su uso.

\section{Triángulo}

12728. Triángulo de retoque abrupto sobre sílex de grano fino a muy fino de color marrón claro. Cara dorsal patinada de amarillo mientras que en la ventral la alteración afecta a una banda alrededor de todo su perímetro. Está completo. L.: 13 mm; A.: 11 mm; E.: 3 mm. Peso: 0,3 g. No se aprecia más evidencia que la presencia de microsaltados a lo largo del borde bruto. No se aprecian huellas de uso. 


\section{Puntas de dorso}

40889. Laminita apuntada con borde abatido en sílex de grano fino a muy fino de color gris oscuro, puntualmente patinado de amarillo. Está rota, al presentar una fractura proximal con lengüeta. L.: 26 mm; A.: 6 mm; E.: 2 mm. Peso: $0,3 \mathrm{~g}$. Aunque a simple vista la pieza presenta un aspecto idóneo para la observación microscópica, en realidad, se encuentra fuertemente afectada por alteración térmica que ha provocado un intenso craquelado (fig. 8). En la observación no se reconoce ningún tipo de evidencia laboral más allá de la fractura compleja mencionada. El filo bruto presenta numerosos microsaltados. Posiblemente usada.

12726. Laminita apuntada con borde abatido en sílex de grano fino a muy fino de color gris. Está rota, al presentar una fractura proximal con lengüeta. L.: 19 mm; A.: 5 mm; E.: 3 mm. Peso: $0,3 \mathrm{~g}$. Se trata de una pieza básicamente idéntica a la anterior, aparentemente bien conservada, pero que al microscopio presenta claras evidencias de una intensa alteración térmica por fuego (fig. 7). El filo bruto se encuentra afectado por numerosos microsaltados, hay áreas de redondeamiento en los salientes y esconces del dorso (posiblemente del enmangue) y una plataforma de abrasión con estrías en la cara ventral, en el filo bruto, muy próxima a la fractura compleja. Las pieza se considera usada.

40626. Fragmento de lámina apuntada con borde abatido en sílex de grano fino completamente patinado de blanco-amarillento. Está rota. Falta una pequeña parte del extremo distal por la presencia de una fractura burilante desarrollada a expensas del filo bruto, y presenta una fractura seca medial o proximal. L.: $17 \mathrm{~mm}$; A.: $6 \mathrm{~mm}$; E.: $2 \mathrm{~mm}$. Peso: 0,2 g. La observación microscópica es deficiente por la pátina y el desarrollo de un intenso lustre de suelo que incluso ha rellenado fisuras generadas junto al dorso durante el proceso de retoque. Redondeamiento y cierto brillo (indiferenciado) en la punta y acusado redondeamiento del tercio proximal del dorso, con posibles restos de ocre. El resto del dorso está ausente de rastros. La pieza se considera usada y pudo estar enmangada en el extremo de un astil con parte del dorso sirviendo también de punta.

40953. Laminita apuntada con borde rectilíneo y base redondeada en sílex de grano fino a muy fino, de color caramelo puntualmente patinado de amarillo en el dorso, extremo distal y filo bruto. Está completa. L.: 24 mm; A.: 4 mm; E.: 3 mm. Peso: 0,3 g. La observación es mala por la pátina y por el desarrollo del lustre de suelo. Presenta huellas méticas por ambas caras, numerosos microsaltados en el borde bruto, redondeamiento del dorso y huellas tecnológicas (fig. 9). Plataforma de abrasión en la punta con estrías, en el lado del borde bruto, cara ventral. Muy posiblemente usada.

40513. Laminita con borde abatido parcial en sílex de grano fino a muy fino, completamente patinada de blanco amarillento. Está rota. L.: 28 mm; A.: 7 mm; E.: 2 mm. Peso: 0,4 g. La observación es deficiente por la intensidad de la pátina, especialmente en los bordes. Redondeamiento y micropulido en el dorso. El extremo roto presenta una combinación de fractura con lengüeta y fractura burilante. La pieza se considera usada.

13075. Laminita apuntada con borde abatido arqueado sobre sílex de grano fino a muy fino y color caramelo. Aparentemente un buen estado de conservación. Rotura seca en la zona proximal. L.: 30 mm; A.: 7 mm, E.: 3 mm. Peso: 0,5 g. Numerosos microsaltados en el filo bruto. Como en la anterior, presenta redondeamiento y micropulido en el dorso (fig. 16). Plataformas de abrasión con estrías (fig. 12). La pieza se considera usada.

13067. Laminita apuntada con borde abatido, sobre sílex de grano fino a muy fino de color marrón, aparentemente no alterado. Está rota por una fractura seca en la zona medial/proximal. L.: 27 mm; A.: 8 mm; E.: 2 mm. Peso: 0,7 g. Se ve muy bien al microscopio. Tiene huellas metálicas derivadas del tratamiento post-excavación, una ligera abrasión en el borde del dorso y redondeamiento acompañado de un pequeño micropulido indiferenciado en la punta. Posiblemente usada.

12724. Laminita con borde abatido parcial sobre sílex de grano fino a muy fino, de color gris, en un buen estado de conservación. Está rota, con una fractura seca en la zona distal que ha producido un levantamiento adyacente con terminación abrupta en la cara dorsal, y otra fractura seca en la zona proximal. L.: $26 \mathrm{~mm}$; A.: $5 \mathrm{~mm}$; E.: $2 \mathrm{~mm}$. Peso: 0,2 g. No se aprecian huellas de uso.

40288. Fragmento de laminita con borde abatido sobre sílex de grano fino o muy fino de 
color gris con pátina blanco-amarillenta desarrollada sobre todo en los bordes. Está rota por sendas fracturas secas en ambos extremos. L.: $13 \mathrm{~mm}$; A.: $6 \mathrm{~mm}$; E.: $2 \mathrm{~mm}$. Peso: 0,2 g. Cierto redondeamiento del borde retocado en la zona medial, coincidiendo con la zona más saliente. Rastros metálicos y de grafito. No se aprecian huellas de uso.

\subsubsection{CONCLUSIONES}

El conjunto analizado es muy pequeño, de manera que las conclusiones tienen casi el carácter individual de las descripciones que acabamos de realizar, sin poder hacer en ningún caso valoraciones estadísticamente significativas.

Por lo que se refiere a su análisis microscópico, este ofrece ciertas dificultades para la observación debido a la presencia de lustre de suelo en todos los restos, de pátina en buena parte de la serie vista y de alteraciones térmicas de carácter intenso en algunas, en concreto en cuatro de ellas.

El no reconocimiento de huellas de carácter laboral en las piezas no supone necesariamente que no hayan sido utilizadas, pero lógicamente impide cualquier tipo de atribución funcional. Partiendo de este hecho, y por lo que respecta a las huellas de carácter laboral registradas, estas se concretan en tipos que no tienen un peso diagnóstico muy elevado como las plataformas de abrasión, fracturas (salvo que sean de alguna variante compleja) y la presencia de micropulidos, aunque siempre muy puntuales y un estadio indiferenciado en su desarrollo. Cuando han ofrecido mayor extensión y desarrollo, observado en las puntas, afectando a los dorsos o partes de ellos (en asociación con redondeamientos), esto nos ha llevado a ponerlos en relación con el enmangue.

En cualquier caso, se puede señalar que todos los usos registrados y los posibles usos se corresponden con elementos de proyectil. Que en el caso de los trapecios resulta significativo (a pesar de los pocos efectivos), y al tiempo refuerza la interpretación, la presencia en tres piezas (de las siete) del mismo tipo de fractura burilante afectando a un extremo del lado largo no retocado. Otro trapecio más podría haber sido usado mientras que en otros tres no se han registrado huellas. Tampoco el triángulo presenta huellas de uso.

Aunque no se puede afirmar, se puede sospechar la existencia de restos de ocre. A falta de que un estudio analítico pudiera confirmarlo lo cierto es que tales restos aparecen siempre en localizaciones precisas, junto a los dorsos o junto a algún lado retocado de los trapecios y no por el resto de las superficies. Antes del análisis supusimos que alguna pieza, como la 13204 , que presentaba recrecimientos de óxido claramente visibles a simple vista, podría haber sufrido alteraciones postsedimentarias por contacto con elementos metálicos, lo que en cierta medida también habría afectado al propio yacimiento. Tras el análisis de esa pieza nos planteamos si más que el resultado de una alteración postdeposicional, esos recrecimientos no serán el producto de la oxidación de los productos minerales aplicados al mástic y no están, pues, en cierta medida, reflejando de forma aproximada el área de enmangue.

Por lo que respecta a las puntas de dorso, se consideran usadas, con la misma finalidad que los trapecios, cuatro piezas, otra más lo fue muy posiblemente, dos posiblemente y otras dos no presentan huellas laborales. En estas piezas también se ha reconocido la presencia de esos restos minerales siempre en la zona de los dorsos, en relación con redondeamientos y áreas de micropulido-abrasión. Esa asociación se ha interpretado como evidencia de enmangue del útil por esa zona, observándose diferencias. En algunos casos, estos rastros afectaban a la totalidad del dorso conservado por lo que la punta o laminita estaría insertada completamente en un lateral del astil, mientras que en algún caso solo se afectaba parte del dorso, la zona proximal/medial, de manera que la pieza quedaría insertada en el extremo del astil.

Por último cabe indicar que algunas piezas (dos trapecios y dos puntas) se encuentran muy afectadas por alteración térmica. La alteración térmica está presente en un porcentaje bajo en la serie recuperada en el yacimiento. Si tenemos en cuenta que parte de las piezas quemadas también lo están craqueladas y/o rubefactadas, no suponen más del $4 \%$. El grado de alteración de esos trapecios y puntas solo se explica por un contacto directo con el fuego; es decir, no estuvieron cerca, ni debajo de un hogar, sino dentro del hogar. En el caso de las puntas, se trata de las partes distales, y en concreto de una pieza usada y de otra posiblemente (en el caso de los trapecios no se ha podido establecer su uso debido al enorme 
grado de alteración), es decir, que al menos una volvió al campamento. Resulta tentador pensar que lo hizo en la carcasa de un animal y que ese grado de alteración es el resultado de quemarse estando incrustado en un hueso o en una masa muscular, cuando el animal fue cocinado. Semejante grado de alteración también nos resultó llamativo en algunos geométricos del yacimiento de Olvena.

\section{BIBLIOGRAFÍA}

BorrazZO, K. 2004: Hacia una tafonomía lítica. Tesis de licenciatura en Ciencias Antropológicas. Facultad de Filosofía y Letras. Universidad de Buenos Aires.

Domingo, R. 2003: La funcionalidad de los microlitos geométricos. Su aplicación a yacimientos del valle del Ebro. Tesis doctoral. Universidad de Zaragoza.

-, 2005: La funcionalidad de los microlitos geométricos. Bases experimentales para su estudio. Monografías Arqueológicas 41. Zaragoza.

-, 2008: «Caracterización funcional de los microlitos geométricos. El caso del valle del Ebro». En El Mesolítico Geométrico en la Península Ibérica. Monografías Arqueológicas 44. Zaragoza, 375-389.

Fischer, F., VEMING HANSEN, P. y RASMUSSEN, P. 1984: «Macro and micro wear traces on lithic projectile points: experimental results and prehistoric examples». Journal of Danish Archaeology, 3: 19-46.

GIBAJA, J.F. 2002: La función de los instrumentos líticos como medio de aproximación socio-económica. Comunidades del V-IV milenio cal BC en el noreste de la Península Ibérica. Tesis doctoral. Universitat Autònoma de Barcelona.

KEELEY, L.H. 1980: Experimental determination of stone tools uses: a microwear analysis. Chicago.

LABORDA, A. 2010: Análisis de huellas de uso. Su aplicación al estudio de la funcionalidad del instrumental lítico de la Cueva de Zatoya (Navarra). Tesis doctoral. Universidad de Navarra.

LOMBARD, M. 2005: «Evidence of hunting and hafting during the Middle Stone Age at Sibidu Cave, Kwazulu-Natal South Africa: A multianalytical approach». Journal of Human Evolution, 48: 279-300.
MANSUR, M.E. 1983: Traces d'utilisation et technologie lithique: exemples de la Patagonie. Thèse de 3ème cycle. Université de Bordeaux I.

MAZO, C. 1989: Análisis de huellas de uso en útiles de sílex del paleolítico. Aplicación del método al estudio del nivel magdaleniense de Abauntz (Arraiz, Navarra). Tesis doctoral. Universidad de Zaragoza. —, 1997: «Análisis del huellas de uso: del dicho al hecho...». Veleia, 14: 9-40.

Moss, E.H. 1983: The functional analysis of flint implements. Pincevent et Pont d'Ambon: two case studies from the French Final Palaeolithic. BAR International Series 177, Oxford.

Palomo, A. y GiBAJA, J.F. 2001: «Tecnología y funcionalidad de la industria lítica tallada en hábitats al aire libre del nordeste peninsular: los asentamientos neolíticos de la Draga y Plansallosa (Gerona)». Bolskan, 18: 169-179.

PARGETER, J. 2011: «Assessing the macrofracture method for identifying Stone Age hunting weaponary». Journal of Archaeological Science, 38: 2882-2888.

Pelegrin, J. y O'FArrell, M. 2005: «Les lamelles retouchées ou utilisées de Castanet». En Productions lamellaires attribuées à l'Aurignacien. Chaînees opératoires et perspectives technoculturelles. Actes du XIVe congrès de l'UIS 103-121.

Plisson, H. 1985: Étude fonctionnelle d'outillages lithiques préhistoriques par l'analyse des microusures: recherché méthodologique et archéologique. Thèse de 3ème cycle. Université de Paris I.

RoDríGUEZ, A.C. 2011: «Análisis funcional del instrumental lítico tallado: un estudio preliminar». En Benàmer (Muro d'Alcoli, Alicante). Mesolíticos y Neolíticos en las tierras meridionales valencianas (Torregrosa, P. et al., dirs.). Servicio de Investigación Prehistórica del Museo de Prehistoria de Valencia. Serie de trabajos varios 112. Valencia, 205-214.

VAUGHAN, P. 1985: Use-wear analysis of flaked stone tools. The University of Arizona Press.

Villa, P., Boscato, P., Ranaldo, F. y RonchiTELLI, A. 2009: «Stone tools for the hunt: points with impacts scars from a Middle Palaeolithic site in southern Italy». Journal of Archaeological Science, 36: 850-859.

Wilkins, J., Schoville, B.J., Brown, K.S. y CAZAN, M. 2012: «Evidence for Early Hafted Hunting Technology». Science, 338: 942-946. 


\subsection{ESTUDIO DE LAS MATERIAS PRIMAS LÍTICAS}

\section{RAÚl LEORZA ÁlVAREZ DE ARCAYA}

El objetivo de este estudio es establecer la relación entre los artefactos encontrados en un contexto arqueológico cerrado, como es la ocupación mesolítica del Cabezo de la Cruz, y los lugares de afloramiento de las MP, distinguiendo entre aquellos localizados en posición primaria y los encontrados en posiciones secundarias. Los primeros los consideraremos geológicamente más viables, dado que se encuentran encajados en roca y ofrecen mayor información, si bien es cierto que la mayoría de las MP en época prehistórica se obtenían de afloramientos secundarios, ya que la disponibilidad y facilidad de acceso a estos depósitos era mayor dada su cercanía a los lugares de hábitat. Queremos, en definitiva, detectar grupos de afloramientos de sílex que nos indiquen las zonas de explotación y abastecimiento utilizadas por los habitantes del poblado.

El proceso de investigación, como es habitual en este tipo de ensayos, comporta diferentes fases con aplicación de diferentes técnicas:

1. Determinación del marco geológico a partir de un primer trabajo de laboratorio en el que es necesario consultar diferentes cartografías así como la bibliografía especializada. Con posterioridad se desarrolla el trabajo de campo que trata, mediante prospecciones intensivas, de identificar los afloramientos, recogiendo las muestras correspondientes que, posteriormente, serán analizadas, estudiadas y clasificadas mediante la elaboración de láminas delgadas.

2. Estudio de los materiales recuperados durante el proceso de excavación, basado en apreciaciones macroscópicas y un posterior trabajo de laboratorio basado en el estudio de las láminas delgadas realizadas sobre una muestra de los restos arqueológicos seleccionados.

3. Consideraciones finales. Estudio comparativo de materiales y resultados de las fases 1 y 2 y redacción de las conclusiones.

En la primera fase del estudio se ha recurrido a los mapas topográficos de la zona para intentar conocer el medio y localizar posibles canteras: Dehesa El Boalar, escala 1:25000 (383-I); La Muela, escala 1:25000 (383-III); María de Huerva, escala 1:25000 (383-IV); Muel, escala 1:25000 (411-I); Jaulín, escala 1:25000 (411-II).
A continuación, se han utilizado los Mapas Geológicos: Zaragoza, escala 1:50000 (383) y Zaragoza, escala 1:200000 (32). En el primero, prestamos especial atención al Terciario ya que la mayoría de los sílex susceptibles de ser trabajados por el hombre se suelen localizar en este contexto. Así, identificamos dos formaciones de gran interés:

a) Montes de Castejón (7). Unidad genético sedimentaria definida en estos montes donde su constitución es esencialmente carbonatada perteneciente al Aragoniense medio/superior. Se localiza en la vertiente meridional y septentrional de La Muela y la Plana, así como al E de Botorrita. Aquí aparecen sílex en nódulos de color gris azulado, definiéndose dos tramos: sílex/ calizas-margas; carbonatos-margas.

b) Unidad San Caprasio (8). Unidad genético sedimentaria definida en la sierra de Alcubierre donde su constitución es predominantemente carbonatada. En la facies carbonatada aparecen interestratos de margas verdes y nódulos de sílex botroidal, abundantes y de tamaño variable. En las margas abundan los núcleos de pirita framboidal.

En el segundo mapa (E/1:200000), mucho mayor y por ello más genérico, volvemos a localizar la presencia de sílex dentro del terciario de la Depresión del Ebro. Se distingue una formación central, denominada formación de yesos de Zaragoza (o fm. Zgz), constituida por yesos masivos, yesos concreccionares o nodulosos, limos y arenas yesíferas con masas de alabastro, margas yesíferas y, subordinadamente, algunos horizontes lenticulares de halita y algunas sales solubres como la epsomita, mirabilita o thenardita. Las formaciones calcáreas que culminan el relleno mioceno del Ebro se denominan fm. La Muela, $\mathrm{fm}$. la Plana y fm. Borja. Las tres al S del Ebro y separadas por los principales valles tributarios en la orilla derecha del río principal. En general, se trata de plataformas calcáreas, con bancos de calizas, calizas pulverulentas e incoherentes, limos, margas y alguna pasada yesífera. Es aquí donde se nos menciona el sílex encajado en las calizas en forma de masas y nódulos.

De la misma manera, se apunta la presencia de sílex en las terrazas definidas en el río Huerva, con potencias entre 3-5 m. Presentan máximas en contenidos de cantos de caliza y sílex del terciario. Esta presencia la adscribimos a MP en posición secundaria, es decir, que se trata de 
materiales arrastrados hacia las terrazas desde cotas superiores, desde la posición primaria.

También existen referencias a la presencia de sílex en las antiguas canteras que, como tal, nos ofrecen un punto de información muy importante.

Gracias a estos planos, podemos hacernos una imagen de dónde podemos localizar las muestras de sílex:

- Altiplanicies de La Muela y la Plana. Se trata de dos mesetas dominadas por depósitos carbonatados y separadas por el valle de $\mathrm{La}$ Huerva. Presentan unas cotas máximas de 637 y $647 \mathrm{~m}$, respectivamente. En la primera, se detecta una ligera pendiente hacia el N-NO que ha favorecido un drenaje superficial hacia en Jalón. El mismo fenómeno se aprecia en la segunda hacia el Huerva.

- Corredor del Ebro y valle del Huerva. Constituyen las zonas más deprimidas de la hoja, marcando los cauces actuales de los ríos los niveles de base locales o regionales. Están bien definidos por los depósitos fluviales de las terrazas bajas y medias (hasta los $30 \mathrm{~m}$ ) y peor por las altas, generalmente desmontadas por procesos erosivos posteriores.

Además de los datos relevantes proporcionados por la cartografía antes comentada, tenemos constancia de la existencia de formaciones de sílex en la literatura geológica y arqueológica. Destacaremos la publicación de Mazo y Cuchí (1992) donde llevan a cabo un estudio de varias muestras de sílex recogidas por todo Aragón. De este estudio hemos podido extraer tres de ellas que afectan al área que nosotros estamos estudiando ahora. Se trata de dos muestras de silexita recogidas en el entorno del cabezo de Contrebia Belaisca (Botorrita), adscritas al Mioceno con un alto porcentaje en sílice (80-95\%); la otra corresponde a una caliza silicificada recogida en Muel perteneciente al Mioceno, dentro de la formación Longares. Su mineralogía presenta solamente un $30 \%$ de sílice, con un $60 \%$ de carbonatos.

Como puede verse, entre las muestras analizadas se hace referencia a la silexita, este término es el que se utiliza en Francia para denominar a los sílex que aparecen en capas, de la misma manera se utiliza para nombrar a un tipo de roca ígnea compuesta por cuarzo primario (del 60 al 100\%). Para no confundir los dos tipos es preferible utilizar para la segunda el término cuarzolita. De todas maneras creemos que será de mayor utilidad el uso del término generalista sílex para las muestras en campo si bien se debe aquilatar una vez se proceda al estudio en laboratorio mediante láminas delgadas.

Dado que el yacimiento se encuentra muy cercano al río Huerva, debemos hacer especial hincapié en el estudio de sus terrazas, en especial las de la margen izquierda donde encontramos todos los niveles perfectamente distribuidos y con escasas alteraciones antrópicas, mientras que en la derecha, en algunos tramos concretos, localizamos hasta los tres niveles inferiores. Los depósitos están constituidos por arenas, limos y cantos de cuarcitas, calizas mesozoicas, grauwacas, areniscas, clastos de caliza y sílex neogeno en la mitad N de la zona. Según Yetano (1987), en la terraza II, en el tramo entre María de Huerva y Zaragoza, aguas abajo de Cuarte, aparece en la margen izquierda sílex. Este nivel de terraza se encuentra fosilizado por aportes laterales constituidos por un paquete de limos con algunos cantos angulosos procedentes de las calizas terciarias de La Muela que también suministran sílex. Hacia el exterior, igualmente, se localizan MP en los mismos glacis. La litología de estos la constituyen niveles de gravas (cuarcitas, caliza jurásica, caliza miocena, sílex y arenisca), areniscas y limos. Estos cantos presentan un redondeamiento variable, de esta manera, los cantos neógenos son bastante angulosos, con un tamaño variable de 3 a $20 \mathrm{~cm}$.

Otra zona dentro del valle que se debe estudiar con sumo cuidado son los valles de fondo plano (vales) y los conos de deyección. Debido al abarrancamiento de estos valles se pueden observar las características del depósito. Vemos que su potencia es variable y oscila entre los 4 y 10 metros, incluso a lo largo del mismo valle. Estas vales están formadas por niveles de gravas y bloques de yeso, caliza, areniscas y sílex que se alternan con arenas de grano fino y limos. Estos sílex que identificamos aquí se encuentran en posición secundaria, así pues se deberán localizar estos materiales en el relleno superior de las vales.

\subsubsection{PROSPECCIONES E IDENTIFICACIÓN DE MATERIAS PRIMAS}

\section{Prospecciones intensivas}

Una vez estudiada la cartografía y literatura geológica de la zona, podemos hacer balance de los resultados obtenidos: 
- Existen dos grandes formaciones muy bien identificadas que dan abundantes y buenos resultados sobre sílex: las formaciones Montes de Castejón y San Caprasio;

- Se detectan numerosas zonas donde se puede localizar sílex, aflorando directamente en el suelo en forma de riñones;

- Conocimiento por parte de la mayoría de los arqueólogos, y prehistoriadores en particular, de la existencia de un sílex de una calidad excelente en forma de riñones de color negro con un córtex muy fino, blanco caloso, conocido como sílex de Botorrita cuyos afloramientos se encuentran cercanos al yacimiento del $\mathrm{Ca}$ bezo de la Cruz.

Con estas premisas, en una primera fase nos proponemos revisar todas las canteras que se localizan en esta zona para poder observar in situ el corte estratigráfico generado por las mismas. En este sentido se ha iniciado la prospección geológica, centrándonos en aquellas formaciones que presumiblemente nos van a dar mejores resultados. Así, pues, se han diseñado una serie de salidas centradas en varios puntos muy concretos y un examen generalizado del entorno del yacimiento y del entorno de la cuenca del Huerva. Hemos prospectado todo el terciario y el cuaternario de esta zona.
1. Montes de Castejón. La Plana de Zaragoza y la Plana de La Muela. Se han revisado sistemáticamente las zonas con estas formaciones geológicas localizando afloramientos de sílex en posición primaria, encajados en roca. Se ha procedido a la documentación fotográfica, a la cumplimentación de las fichas de campo y a la toma de muestras.

2. San Caprasio. También en las altiplanicies de la Plana de Zaragoza y la Plana de La Muela. Se han recogido muestras y se han documentado los afloramientos en posición primaria.

3. Las Vales. Se ha llevado a cabo la misma metodología que en los anteriores afloramientos, si bien en estos casos las muestras aparecen en posición secundaria.

4. Terrazas del Huerva. Aplicada la misma metodología, al igual que en el anterior, los materiales se encuentran en posición secundaria.

Las salidas al campo se han diseñado de manera ordenada en dos fases: primero, la margen derecha del Huerva y, después, la izquierda. Durante este proceso se han identificado 18 afloramientos en los que se han recogido muestras y de los cuales se han hecho 15 láminas delgadas. Veamos cada uno individualmente.

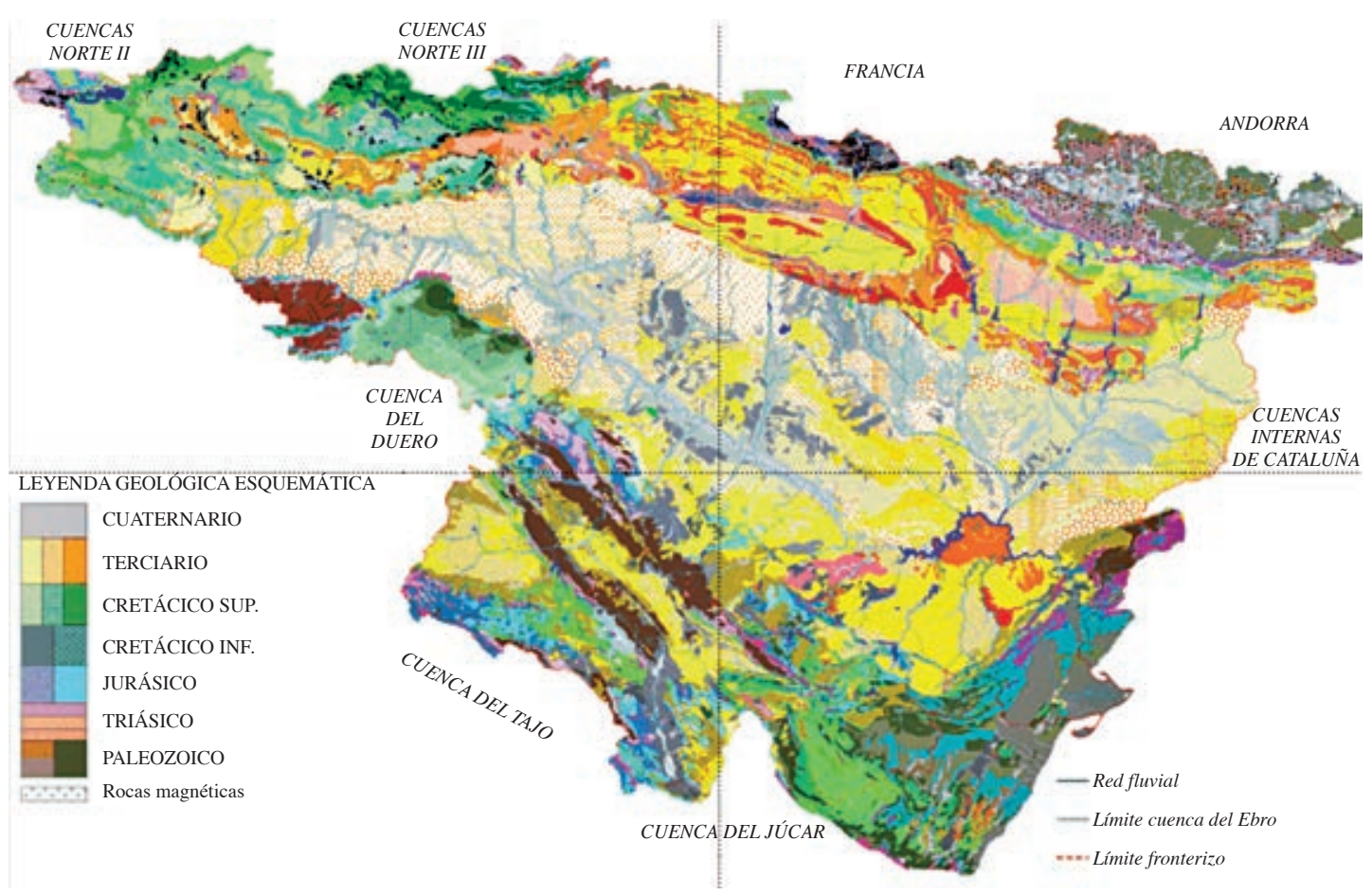

Mapa geológico del valle del Ebro. 


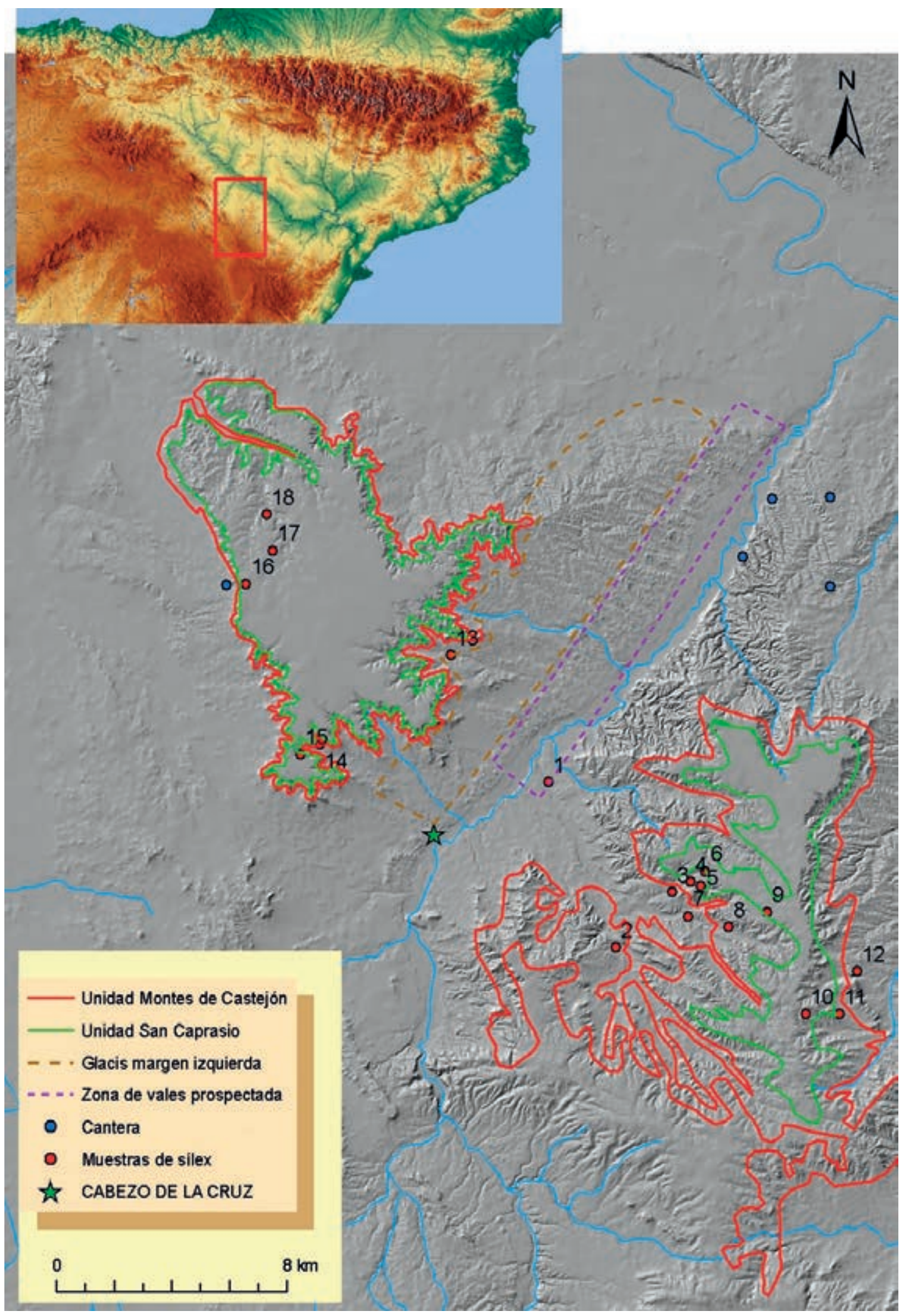

Afloramientos naturales de sílex en el entorno del Cabezo de la Cruz y ubicación de las muestras analizadas. Nódulos estratificados entre las calizas blancas miocenas de las unidades San Caprasio-Montes de Castejón que coronan las plataformas estructurales de La Muela y la Plana de Muel-Jaulín. Sílex en posición secundaria en los glacis y vales que se extienden por las márgenes del río Huerva. 


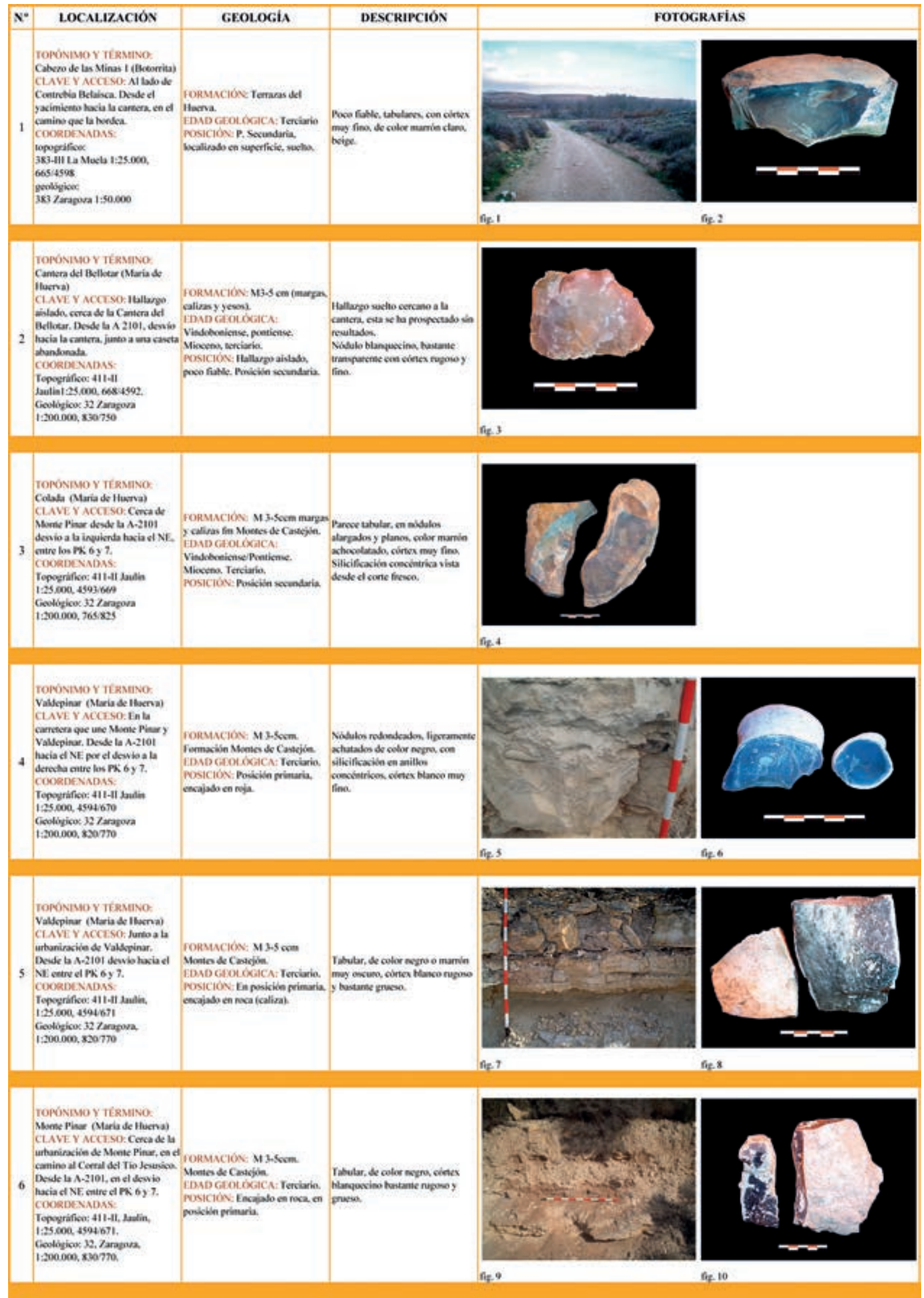




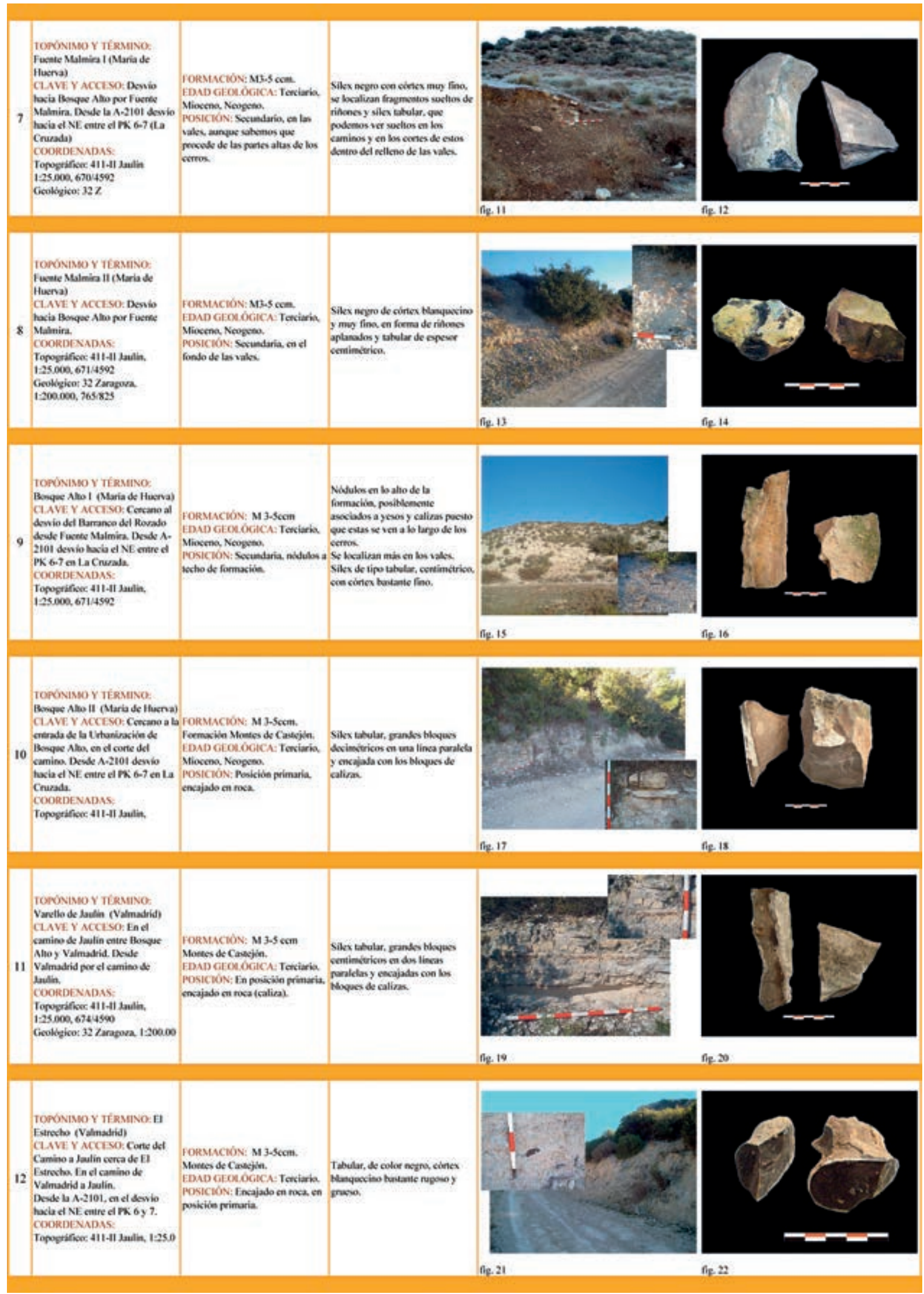




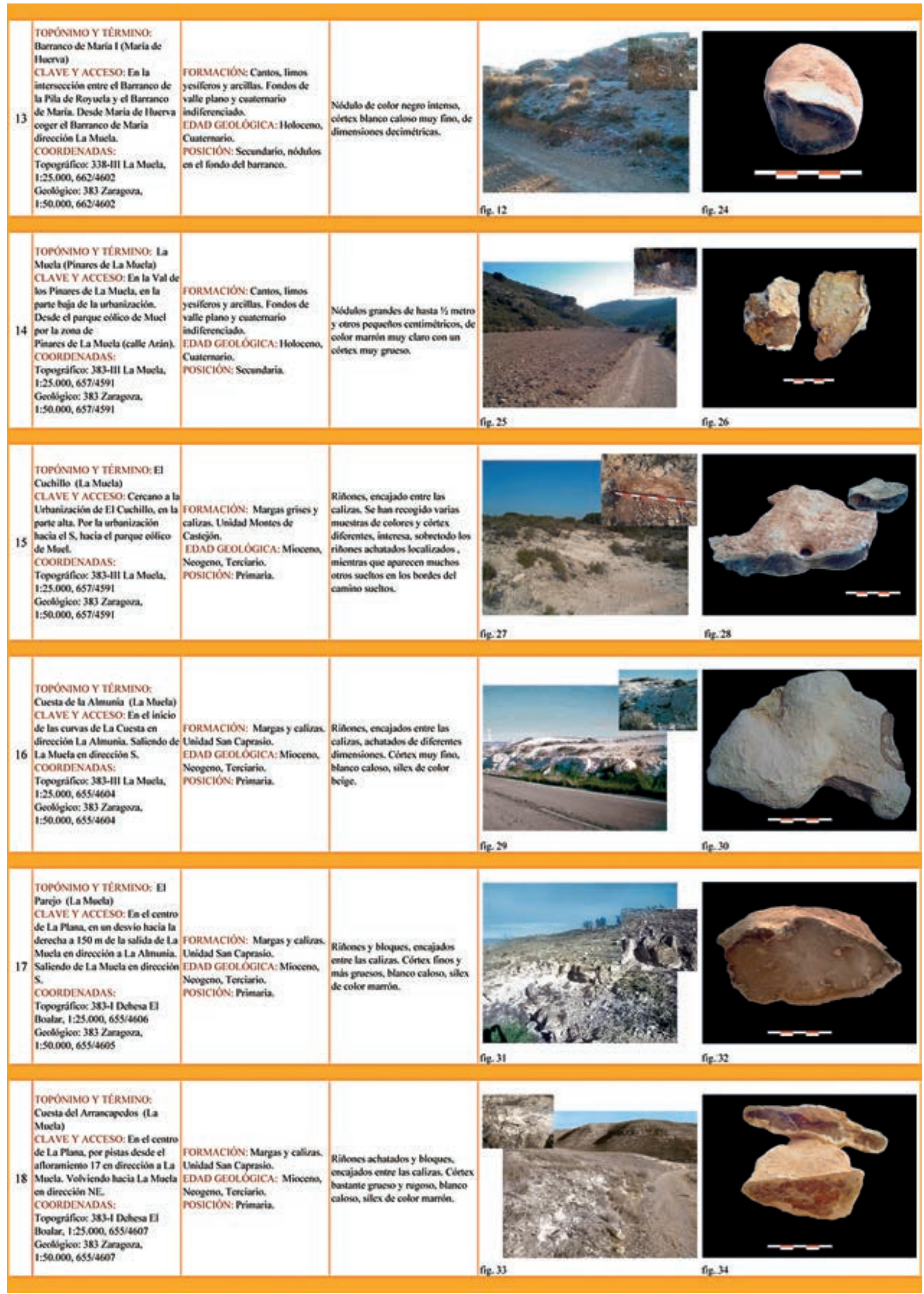


Con los datos obtenidos, analizados los materiales recogidos durante el trabajo de campo, se pueden realizar una serie de consideraciones, teniendo en cuenta una serie de variables como:

a) Formaciones geológicas. En este caso son dos fundamentales: Montes de Castejón y San Caprasio, las dos de edad terciaria, donde se ha localizado material en posición primaria. Por el contrario, en vales, glacis y terrazas el material se ha identificado en posición secundaria.

b) Componentes aloquímicos: la presencia de ooides, algas charáceas, ostrácodos, etc., o su ausencia, nos muestran su identificación con un tipo u otro de fauna, de ambiente de formación.

c) Tamaño de grano.

d) Ambiente genético.

e) Modo de afloramiento: tabular o nodular. Es una variable significativa ya que es determinante para su aprovechamiento por parte de las poblaciones prehistóricas.

Así hemos podido identificar cuatro tipos de sílex:
1. Micríticos, generalmente nodulares, con anillos y con bioclastos (charáceas y ostrácodos). Se presentan con \pm bioclastos $\mathrm{y} \pm$ cuarzo detrítico. Formación: Montes de Castejón.

2. Intraclastos, generalmente tabulares, ooidales, con cementaciones interpartícula y laminación algal. Formación: San Caprasio.

3. Tabulares, grumosos (clotted micrite), \pm bioclastos y \pm cuarzo detrítico. Formación: San Caprasio.

4. Pseudogrumosos, tabulares y/o nodulares. Formación: Montes de Castejón y San Caprasio.

Igualmente, teniendo en cuenta el ambiente de formación se han identificado una serie de sílex continentales de ambientes lacustres y palustres:

- Lacustre: con bioclastos como las algas charáceas y los ostrácodos.

- Palustre: con cementaciones vadosas (muy claro en MP 9). No presentan bioclastos lacustres y sí cementaciones vadosas fibrosas (alternancia de calcedonita-cuarcina).

\section{Trabajo de laboratorio: identificación de MP}

Para una mejor identificación de las MP recogidas durante la prospección y su posterior comparación con los materiales arqueológicos, se ha procedido a la realización de varias láminas delgadas.

MP 4

Sílex encajado en caliza.

Descripción microscópica: Sílex con textura de roca original, grano fino (micrítico) y bioclástica, entre los bioclastos hay secciones de tallo de algas charáceas, ostrácodos y otros relictos inidentificables. Son muy patentes los anillos de Liesegang, espaciados de $1 \mathrm{~mm}-0,1 \mathrm{~mm}$. Presenta cavidades de organismos cementadas con megacuarzo (en las paredes aparece el cuarzo fibroso y termina de rellenarse con megacuarzo). Se trata de un sílex de grano finísimo, criptocuarcítico. Algunos de los tallos no aparecen cementados, con porosidad móldica.

MP que aparece en la unidad Montes de Castejón, son nódulos con anillos, micrita conbioclastos. Formada en un ambiente lacustre.

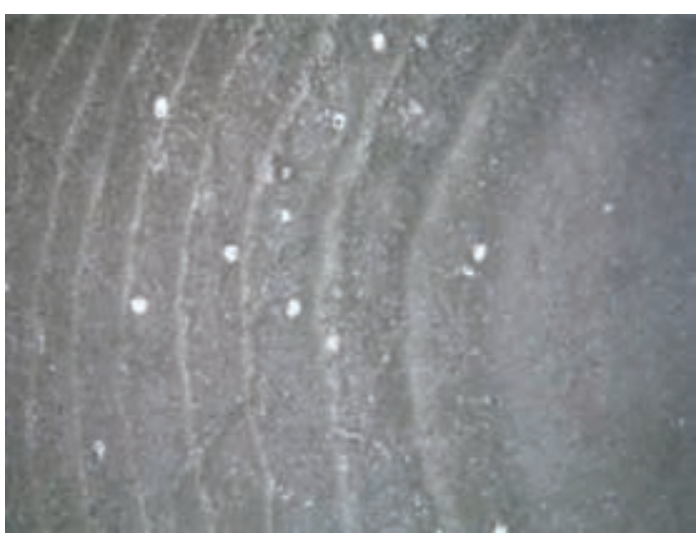

Figura 35. Vista general $10 x$, nícoles cruzados (xpl), textura con secciones de charáceas.

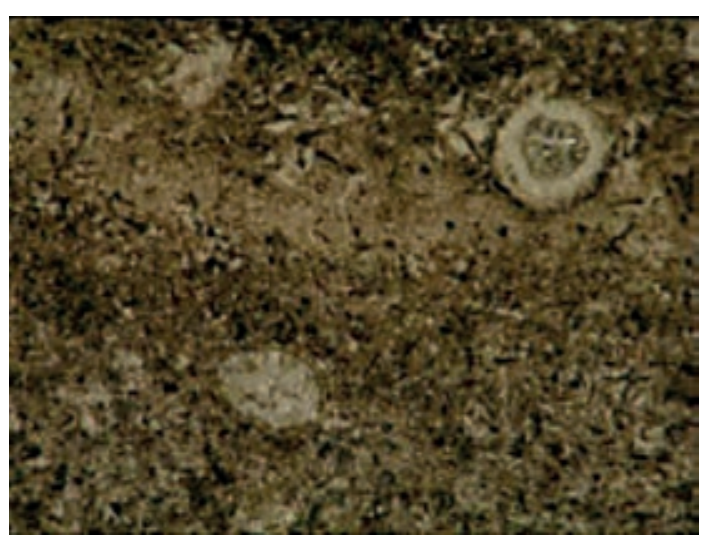

Figura 36. Detalle $70 x$, nícoles paralelos (ppl), sección alga charácea y ostrácodo. 
MP 5

Sílex encajado en caliza.

Descripción microscópica: Sílex de grano muy fino (micro-cripto cistalino), con muchas impurezas, con zonas en el interior sin cementar. Presenta cuarzo detrítico, tamaño arena fina a muy fina, incluso limo. Laminación paralela grosera, porosidad indefinida. Se trata de un sílex algo pseudogrumoso.

Se localiza en la formación Montes de Castejón, en nódulos de tipo pseudogrumoso.

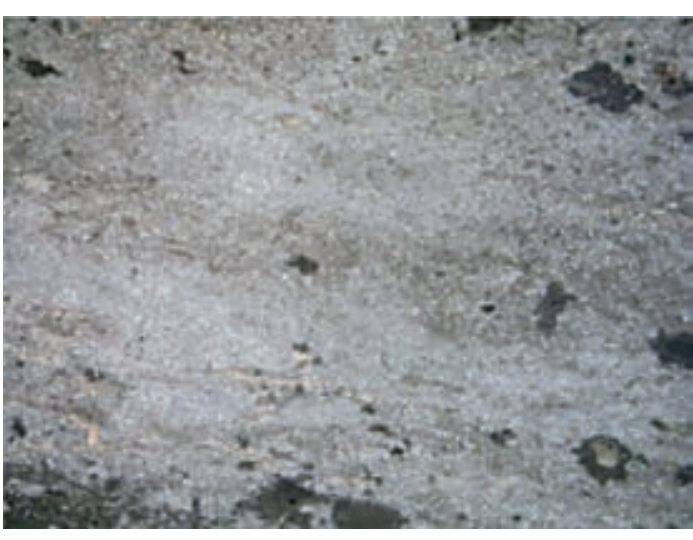

Figura 37. General $10 \mathrm{X}$, xpl.

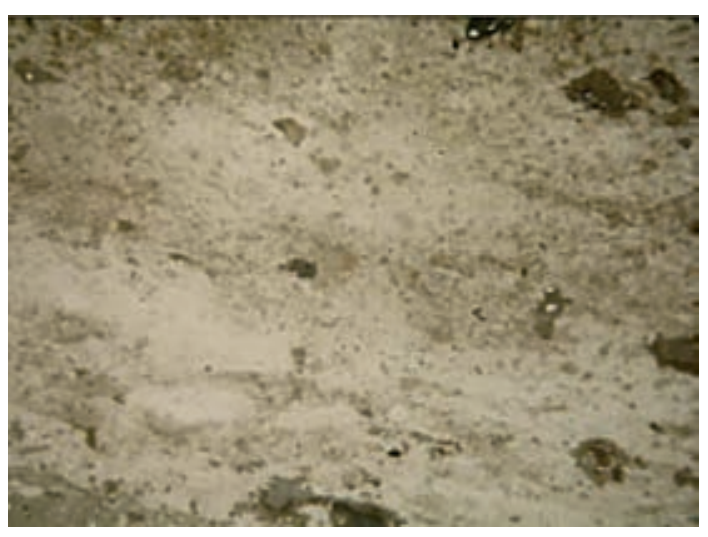

Figura 38. General $10 x$, ppl.
MP 6

Sílex encajado en caliza.

Descripción microscópica: Sílex de textura grumosa (clotted micrite), grano muy fino (cristalino), con cuarzo detrítico, tamaño arena fina, con parches de roca-caja sin silicificar, con abundante porosidad (poros de $0,1 \mathrm{~mm})$.

Aparece en la fm San Caprasio, es tabular de tipo grumoso.

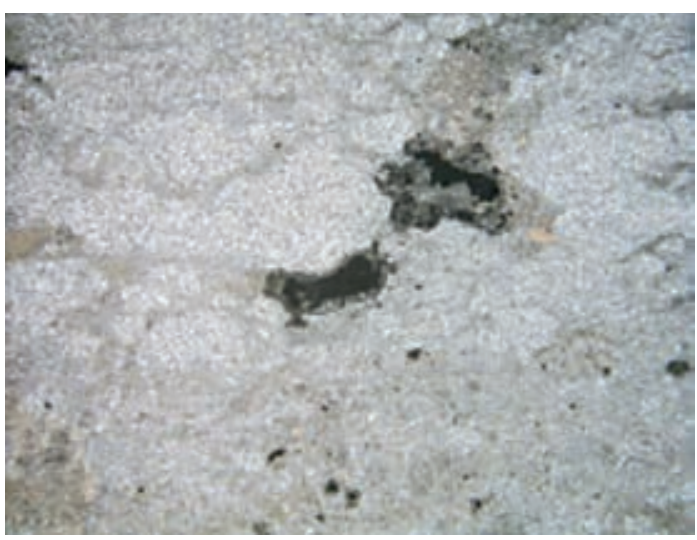

Figura 39. General 10x, ppl, grumos y parches.

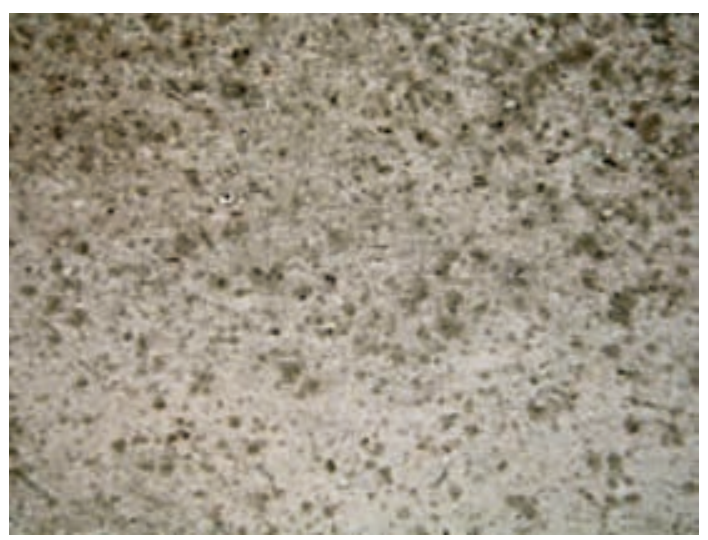

Figura 40. General spot de alteración, 10x, ppl. 
MP 8

Localizado en posición secundaria.

Descripción microscópica: Presenta relictos de algas charáceas y ostrácodos, relictos carbonatados de esparita o microesparita. Sílex de grano muy fino (criptocristalino). Los relictos carbonatados se corresponden con fragmentos de bioclastos identificándose fragmentos de algas, se dibuja una incipiente laminación paralela.

Sílex aluvial con fauna lacustre.

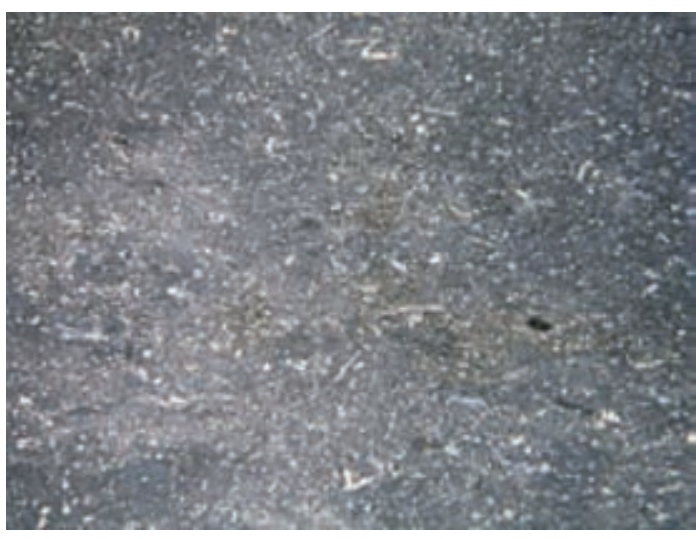

Figura 41. General 10x, xpl.

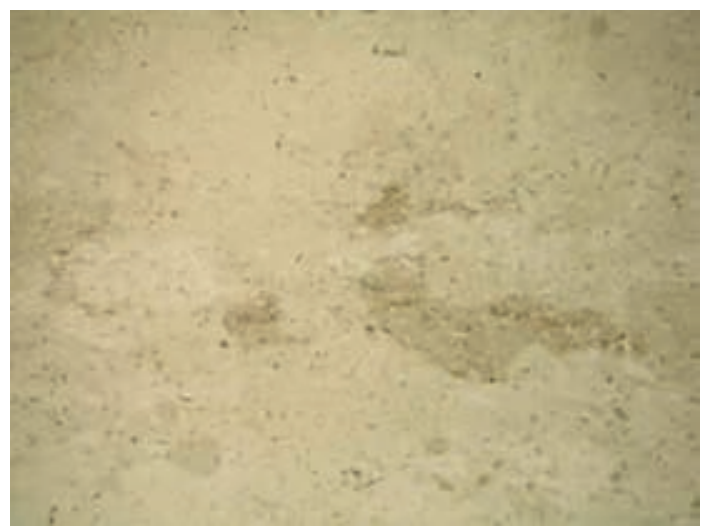

Figura 42. General 10x, ppl.

MP9

Localizado en superficie.

Descripción microscópica: Sílex bandeado, se trata de bandas de laminación algal y otras por intraclastos ooidales $(0,05-0,4 \mathrm{~mm})$. Presenta porosidad interpartícula, cementada por cuarzo fibroso. Estas cementaciones comienzan con finas bandas de calcedonita de $0,1 \mathrm{~mm}$ de espesor, se tapiza y termina rellenándose por cuarzo fibroso (en ocasiones, cuarcita, otras, calcedonita y otras veces formas complejas). Estos cambios indican cementaciones vadoso-fibrosas (alternancia de calcedonita-cuarcina), típico de ambientes palustres, ambiente cambiante de inundación-desecación ${ }^{1}$.

Sílex de la formación San Caprasio, localizada a techo de formación, aparece en forma tabular con intraclastos ooidales.

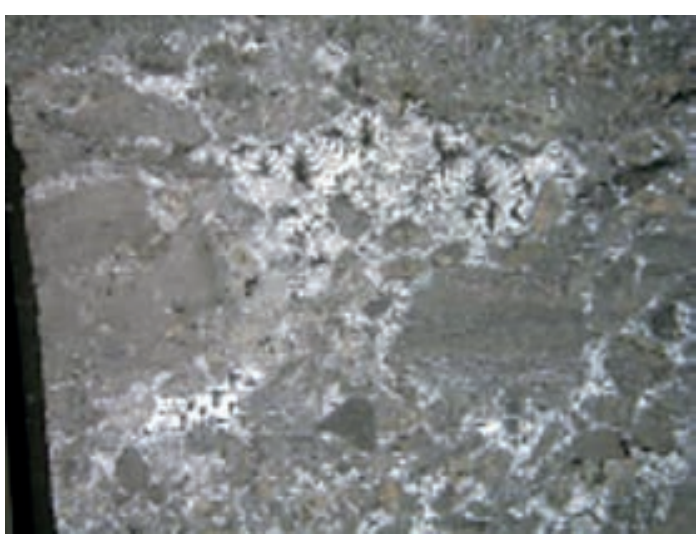

Figura 43. General 10x, xpl, banda de ooides. con cuarzo fibroso.

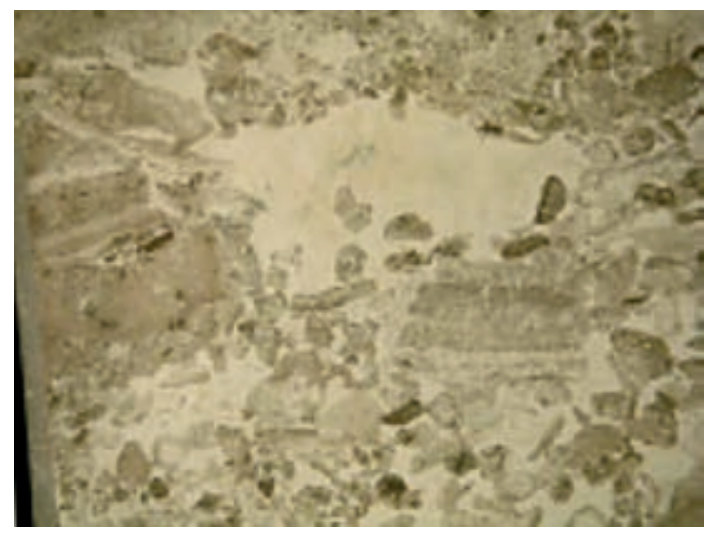

Figura 44. General 10x, ppl, banda de ooides con cuarzo fibroso.

1 Véase A. Tarriño (2001), El sílex en la cuenca vasco-cantábrica y Pirineo navarro: caracterización y aprovechamiento en la Prehistoria. Tesis doctoral. Pie de foto 4.76, p. 106. 


\section{MP 10}

Sílex encajado en caliza.

Descripción microscópica: Sílex micro-criptocristalino, con contenido en bioclastos inidentificables y cantidad de relictos carbonatados, presenta una laminación leve, porosidad móldica y pocos spots de alteración.

Se pueden observar minerales opacos (óxidos de hierro) y secciones de tallos de algas.

Se localiza en la fm San Caprasio, se trata de un sílex tabular micrítico.

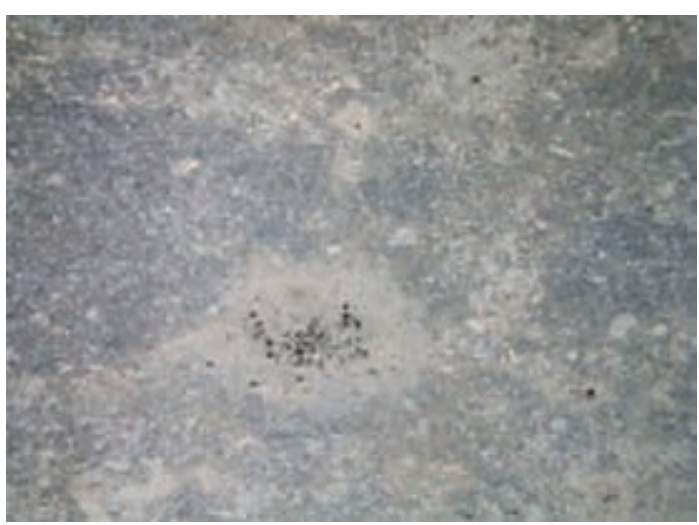

Figura 45. General 10x, xpl.

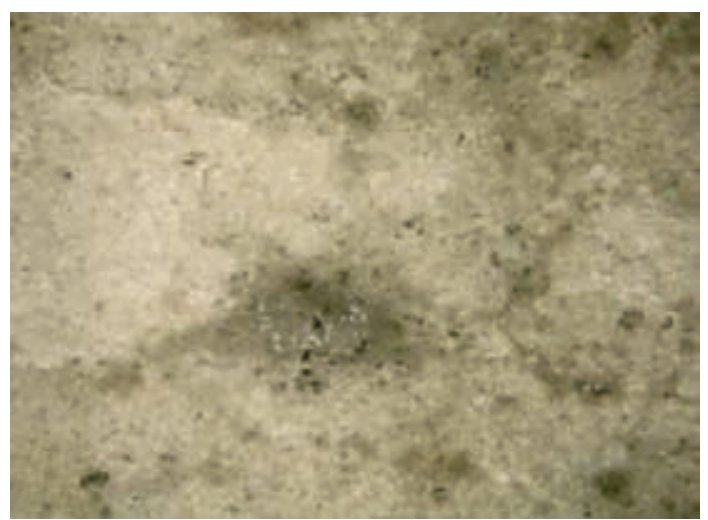

Figura 46. General 10x, ppl.

\section{MP 11}

Sílex encajado en caliza.

Descripción microscópica: Sílex micro-criptocristalino, tabular, se observa una laminación donde se ven bandas de crecimiento posiblemente algal y otras ocupadas por un sedimento movilizado por una textura grumosa (clotted micrite). Presenta ooides de 0,04-1 mm y cementaciones intergranos, exterior de cuarzo fibroso-calcedonita y en el interior megacuarzo. Se identifica cuarzo detrítico, de grano arena fina de 0,1 $\mathrm{mm}$.

Sílex tabular con grumos y bandeado algal de la fm San Caprasio.

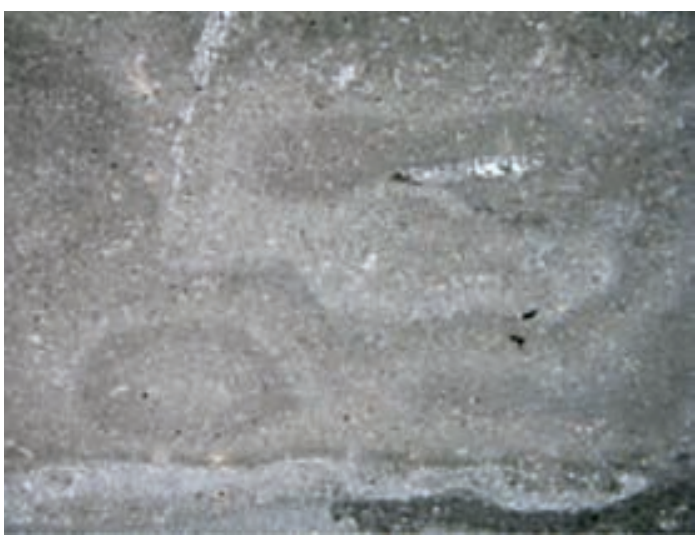

Figura 47. General 10x, xpl.

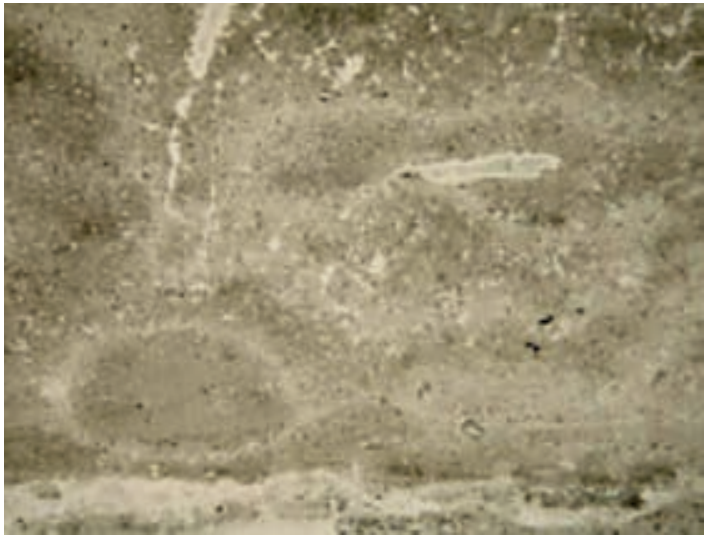

Figura 48. General 10x, ppl. 


\section{MP 12}

Localizado en posición secundaria.

Descripción microscópica: Similar a MP 4: sílex con textura de roca original, grano fino (micrítico) y bioclástica, entre los bioclastos hay secciones de tallo de algas charáceas, ostrácodos y otros relictos inidentificables. Son muy patentes los anillos de Liesegang, espaciados de $1 \mathrm{~mm}-0,1 \mathrm{~mm}$.

Presenta cavidades de organismos cementadas con megacuarzo (en las paredes aparece el cuarzo fibroso y termina de rellenarse con megacuarzo). Se trata de un sílex de grano finísimo, criptocuarcítico. Algunos de los tallos no aparecen cementados, con porosidad móldica.

Sílex aluvial.

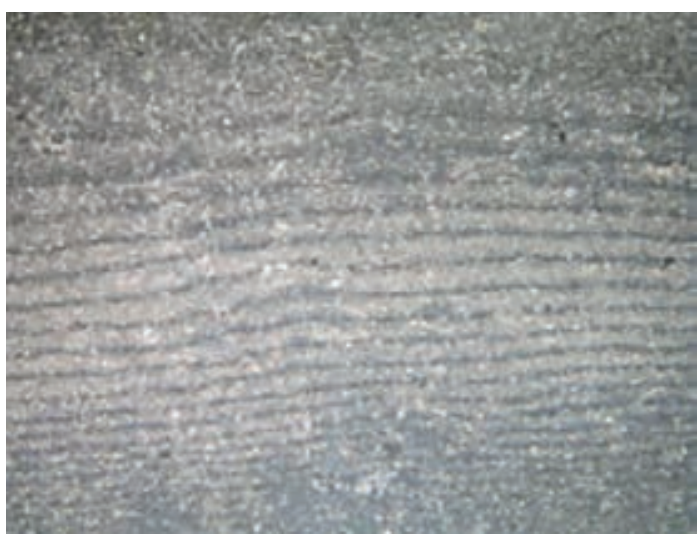

Figura 49. General 10x, xpl.

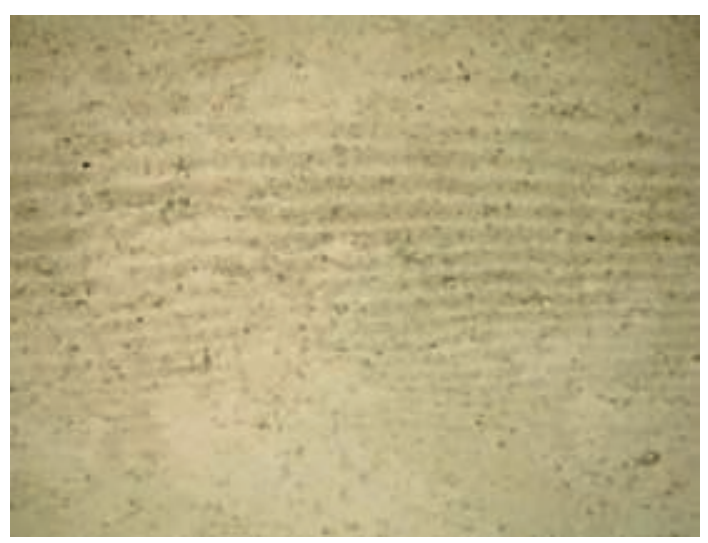

Figura 50. General 10x, ppl.

\section{MP 13}

Localizado en posición secundaria.

Descripción microscópica: Similar a MP 10: sílex micro-criptocristalino, con contenido en bioclastos inidentificables y cantidad de relictos carbonatados, presenta una laminación leve, porosidad móldica y pocos spots de alteración. Se pueden observar minerales opacos (óxidos de hierro y secciones de tallos de algas) pero con menos relictos carbonatados de micrita y bioclastos. Es de cuarzo micro-cripto y tiene cuarzo detrítico.

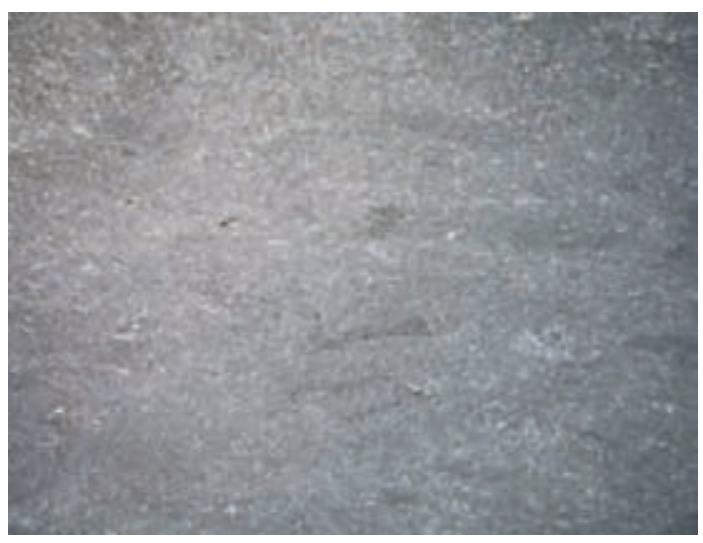

Figura 51. General 10x, xpl.

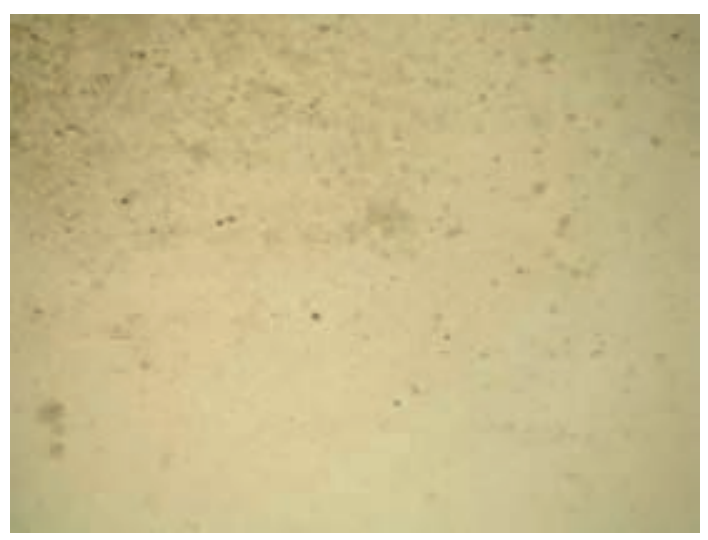

Figura 52. General 10x, ppl. 


\section{MP 14}

Localizado en posición secundaria.

Descripción microscópica: Sílex de grano muy fino (cripto-micro), ferruginizado por alteración, sobre todo en las zonas de porosidad y microfisuras. Presenta una porosidad abundante inter e intrapartícula y textura grumosa (clotted micrite). Se trata de un sílex imposible de tallar.

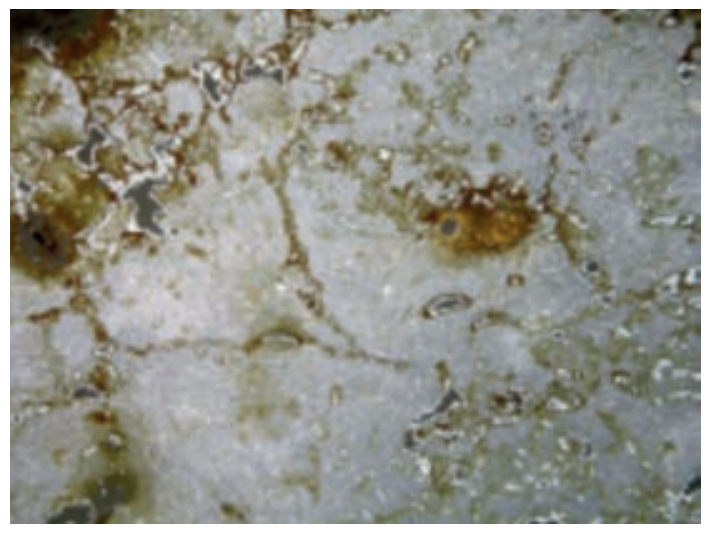

Figura 53. General 10x, xpl.

\section{MP 15}

Sílex encajado en caliza.

Descripción microscópica: Similar a MP 4: sílex con textura de roca original, grano fino (micrítico) y bioclástica, entre los bioclastos hay secciones de tallo de algas charáceas, ostrácodos y otros relictos inidentificables. Son muy patentes los anillos de Liesegang, espaciados de $1 \mathrm{~mm}-0,1 \mathrm{~mm}$.

Presenta cavidades de organismos cementadas con megacuarzo (en las paredes aparece el cuarzo fibroso y termina de rellenarse con megacuarzo). Se trata de un sílex de grano finísimo, criptocuarcítico. Algunos de los tallos no aparecen cementados, con porosidad móldica, aunque ligeramente grumoso.

Se localiza en la fm San Caprasio, son nódulos tabulares pseudos grumosos.

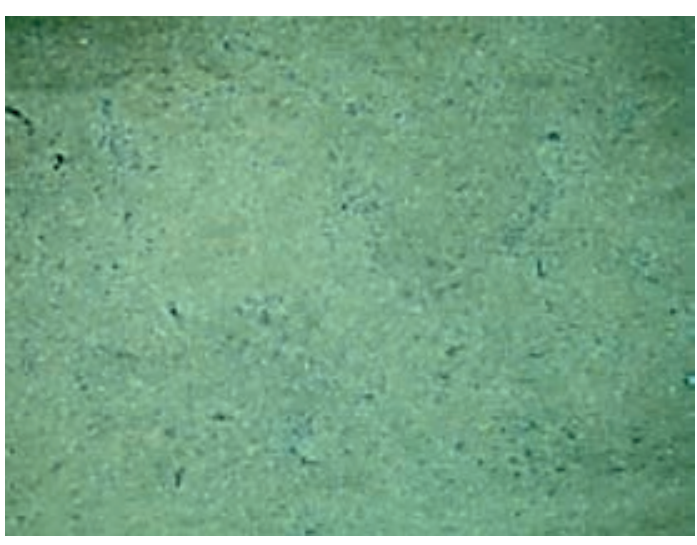

Figura 54. General 10x, xpl.

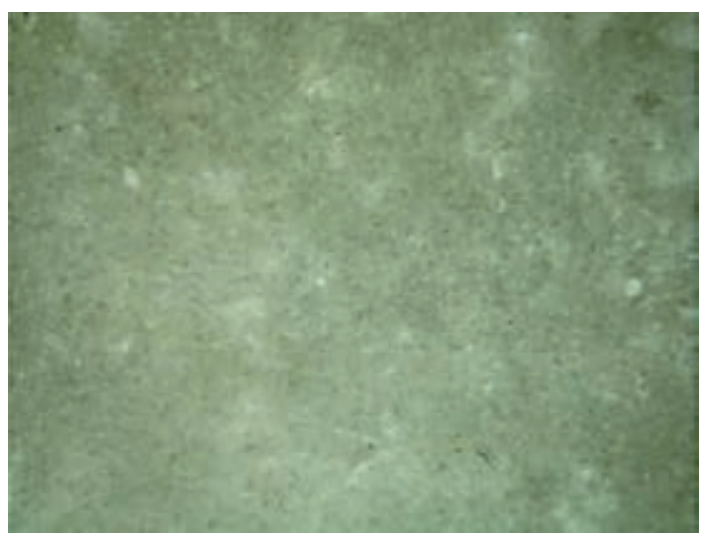

Figura 55. General 10x, ppl. 


\section{MP 16}

Sílex encajado en caliza.

Descripción microscópica: De textura claramente grumosa, clotted micrite. Se localiza en la fm San Caprasio.

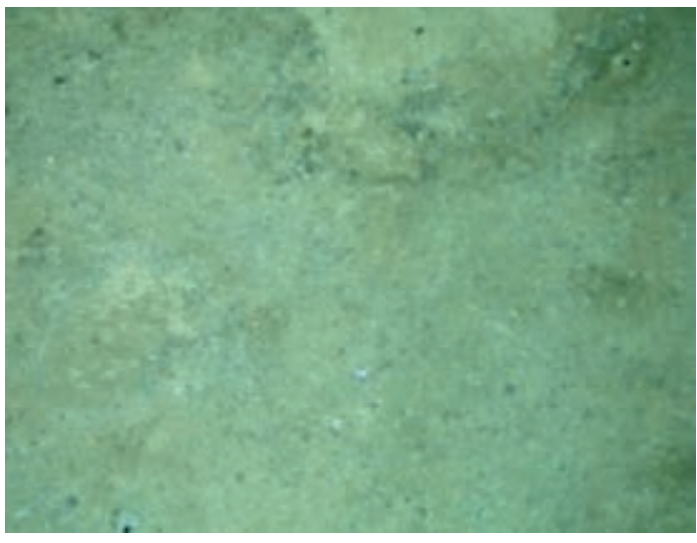

Figura 56. General 10x, xpl.

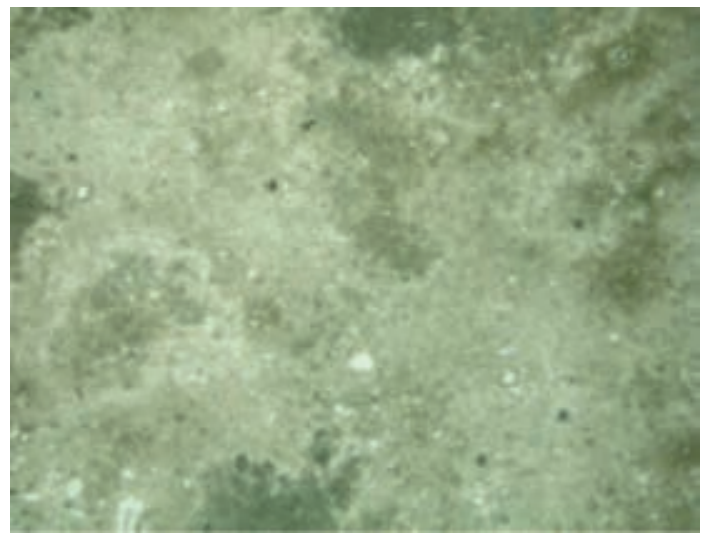

Figura 57. General 10x, ppl.

MP 17

Sílex encajado en caliza.

Descripción microscópica: Similar a MP 16 (de textura claramente grumosa, clotted micrite. Se localiza en la fm San Caprasio).

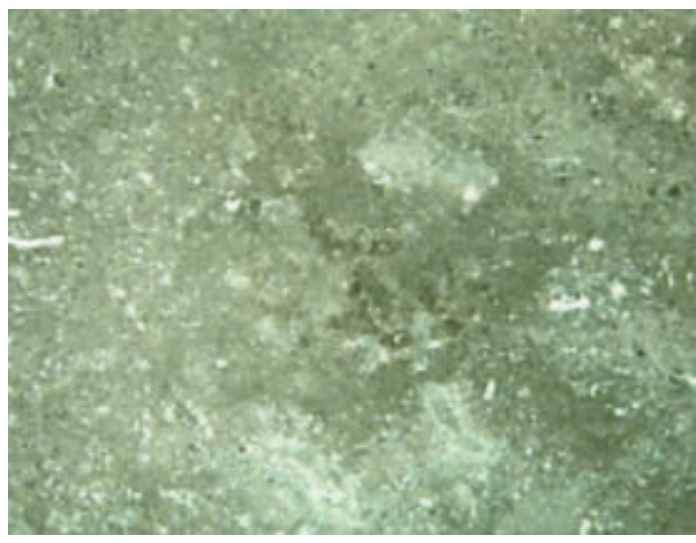

Figura 58. General 10x, ppl. 


\section{MP 18}

Sílex encajado en caliza.

Descripción microscópica: Similar a MP 17 (de textura claramente grumosa, clotted micrite. Se localiza en la fm San Caprasio) con algo más de cantidad de granos de cuarzo detrítico de tamaño arena fina o muy fina. Ligeramente grumoso.

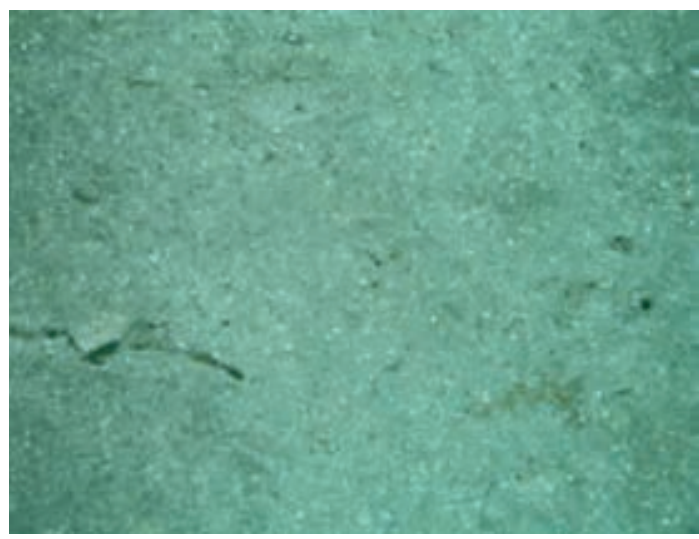

Figura 59. General 10x, xpl.

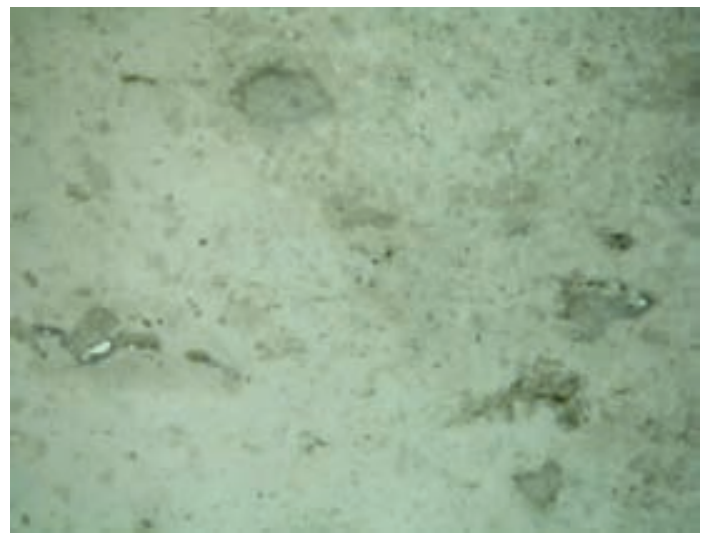

Figura 60. General 10x, ppl.

\subsubsection{LAS MP DEL YACIMIENTO ARQUEOLÓGICO}

\section{Identificación macroscópica}

Atendiendo a factores como coloración y grano de la muestra se realiza una primera clasificación macroscópica. A pesar de esta primera diferenciación, debemos tener en cuenta que los sílex sufren procesos postdeposicionales y diversos tipos de alteraciones antrópicas, los cuales pueden hacer converger las pátinas y generar confusiones. Por ejemplo, la rubefacción provoca que los colores de los sílex cambien hacia tonos rojos y rosas, aunque su color original sea completamente diferente. De la misma manera, se alteran las capacidades mecánicas del sílex logrando una mejor manejabilidad a la hora de la talla. Esta característica ya ha sido identificada en yacimientos como Aizpea (Tarriño 2001). Aparecen restos fuertemente alterados por fuego, alterando este el color y las propiedades mecánicas de las materias primas (la intención era, evidentemente, obtener otro tipo de propiedades).

Como se ha indicado anteriormente, esta primera aproximación es necesariamente personal y subjetiva, pero no por ello carente de sentido puesto que lo que se intenta es poder realizar una división inicial relativamente sencilla que nos permita identificar cada una de las MP empleadas. Como veremos más adelante, esta agrupación por colores podrá variar teniendo en cuenta el contenido petrológico de cada muestra, de esta manera, se llegarán a agrupar en un número sensiblemente menor de conjuntos de MP, atendiendo a características que nos ofrecerá el análisis mediante lámina delgada.

Durante este proceso se han podido identificar varios tipos diferentes de materiales en cuanto a su color, textura, limpieza del corte, geodas, córtex...: factores que consideramos representativos. 
1. (04.36.41D.13188). Núcleo. N. ${ }^{\circ}$ de pieza 2037. UE 1351

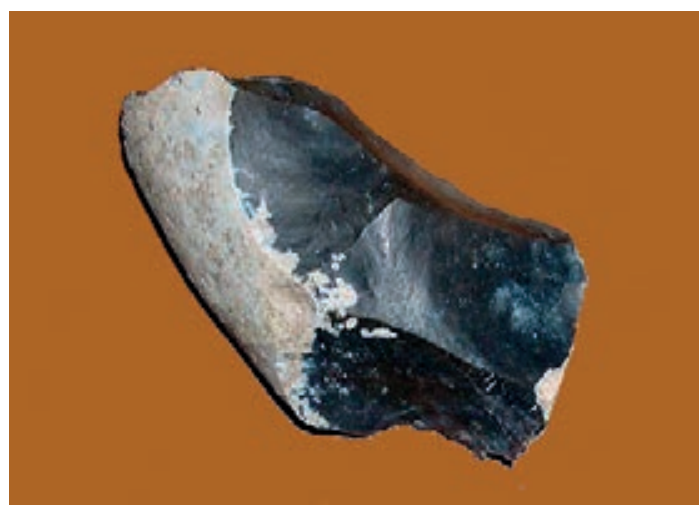

Figura 61. Negro, liso al tacto, córtex fino de color blanco, muy liso, superficie de corte lisa.

2. (04.36.43D.39767). Lasca grande. UE $1000-1351$

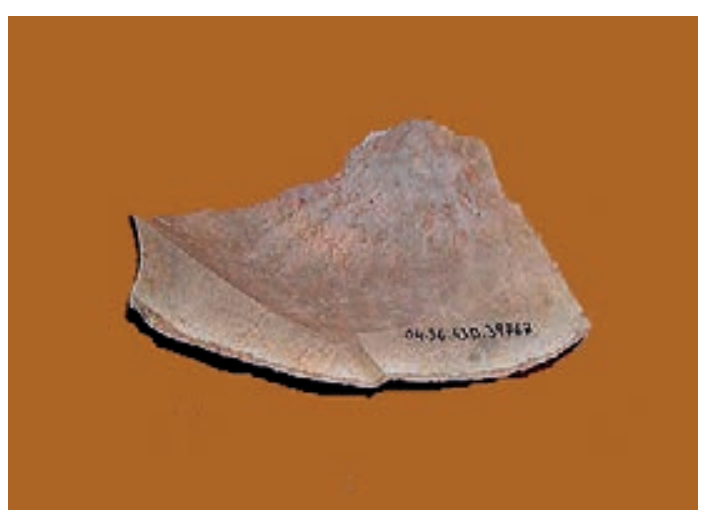

Figura 62. Blanco, áspero al tacto, córtex fino de color anaranjado y áspero, superficie de corte irregular.

3. (04.36.43D.40952). Núcleo. UE 1450

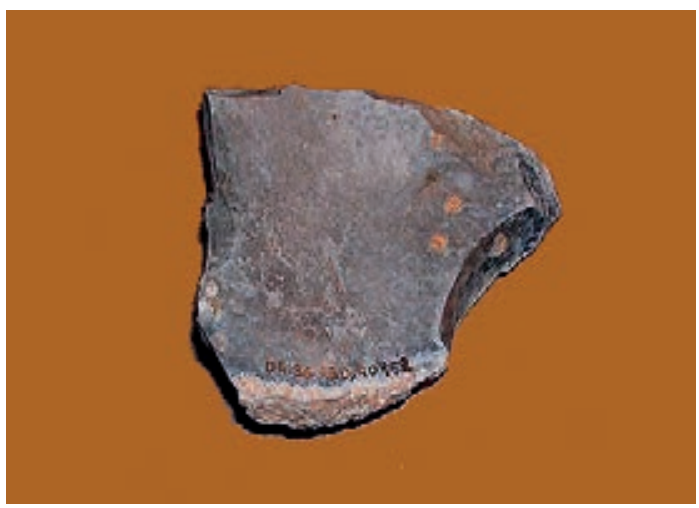

Figura 63. Negro con veteados blancos, córtex fino, blancoanaranjado, rugoso, superficie de corte irregular medio.
4. (04.36.43D.39821).

Indeterminado. UE 1000-1351

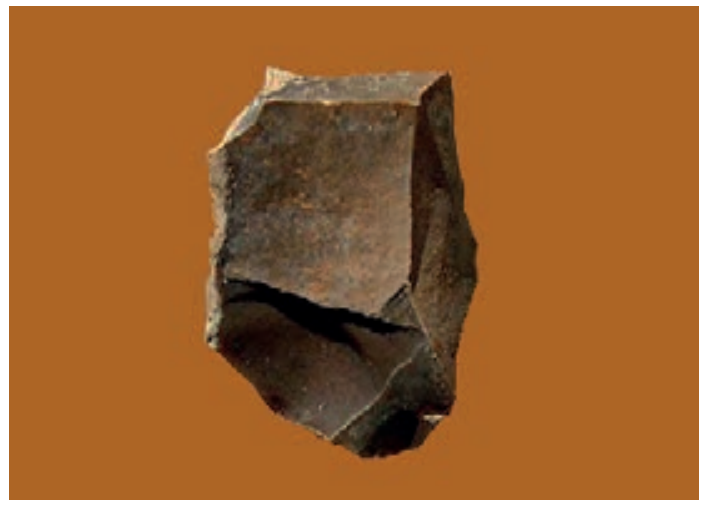

Figura 64. Marrón, liso al tacto, córtex fino de color anaranjado, bastante rugoso, corte limpio (aristas muy rectas).

\section{5. (04.36.41D.13061). Núcleo. UE 1361}

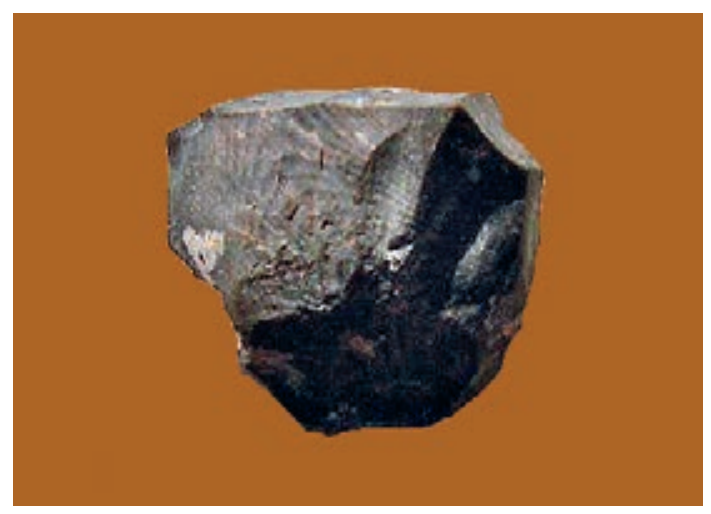

Figura 65. Marrón muy oscuro con veteados paralelos, textura lisa (más áspera que los anteriores), no aparece el córtex, corte irregular con aristas y zonas curvas, perforaciones y desconchados.

\section{6. (04.36.41D.38995). Lasca. UE 1000}

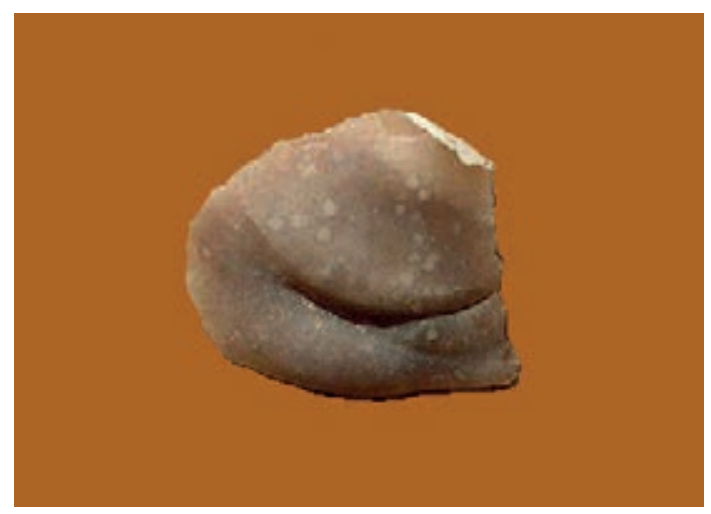

Figura 66. Beige, liso al tacto con manchas circulares blancas, córtex fino liso de color blanco, superficie de corte lisa y limpia. 
7. (04.36.41D.38994). Núcleo. UE 1000

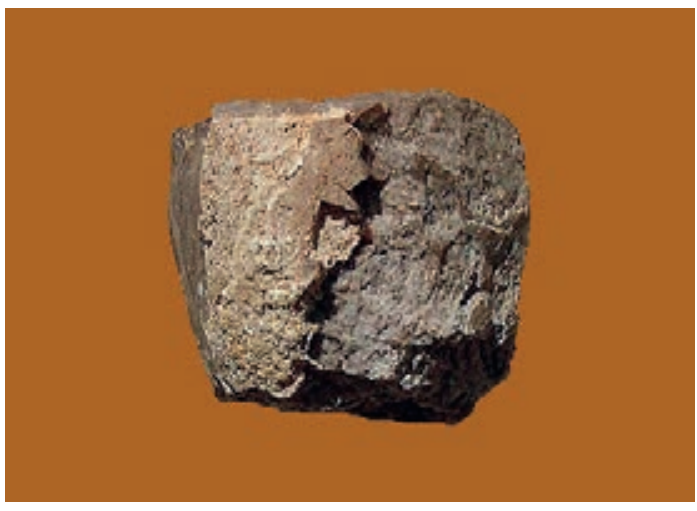

Figura 67. Negro achocolatado, textura lisa, córtex fino de color blanquecino rugoso, superficie de corte lisa irregular muy heterogénea.

8. (04.36.45CDE.40992).Lasca grande. UE 1391

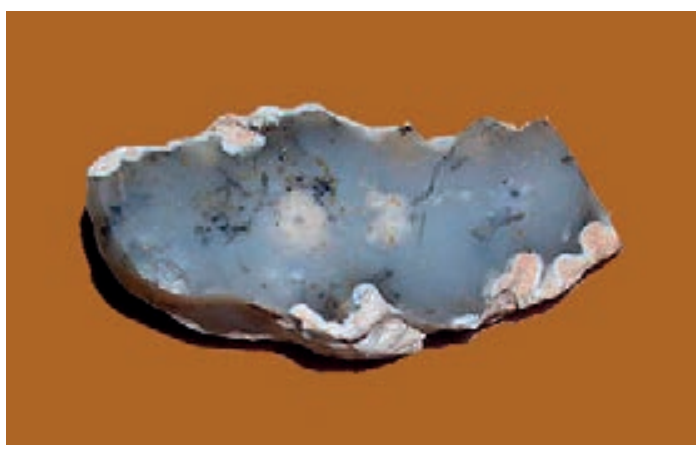

Figura 68. Blanco transparente con intrusiones negras (seguramente fósiles), de textura algo más áspera que los anteriores, con superficie algo más redondeada (aristas más suaves) posiblemente por estar rodado; córtex rugoso con diferentes agujeros, muy irregular, de tacto áspero y heterogéneo en cuento al espesor, de color blanco-anaranjado.

\section{9. (04.36.43E.40002). Lasca grande. UE 1349}

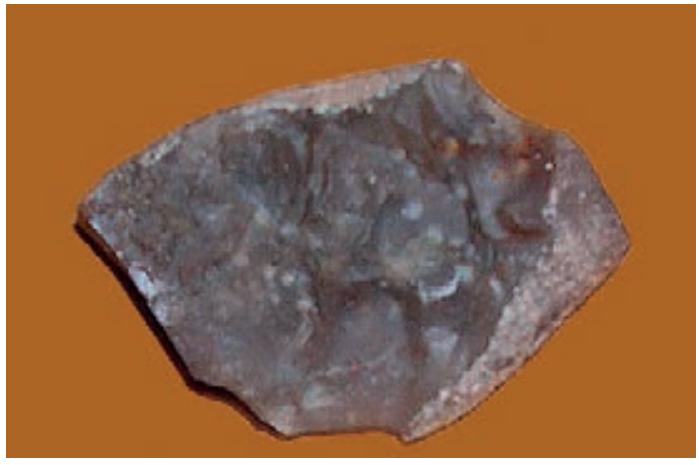

Figura 69. Marrón claro con manchas de color blanco y rojo (¿fósiles?), textura áspera, corte irregular, aristas redondeadas, córtex muy fino de color anaranjado, extremadamente fino.

\section{0. (04.36.39E.39670). Lámina. UE 1000-1397}

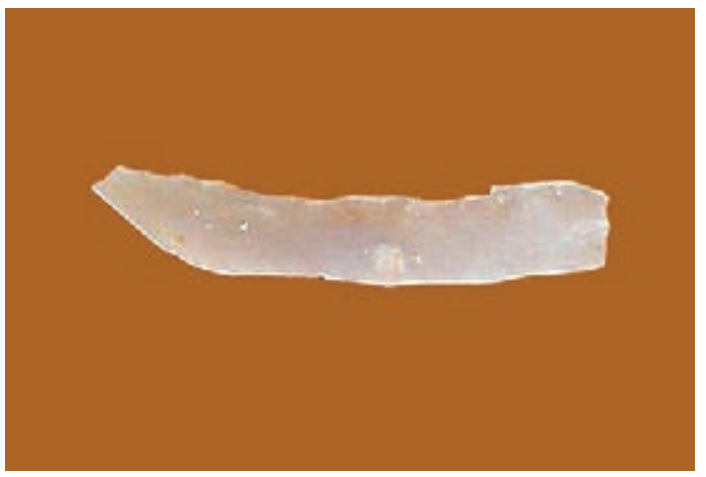

Figura 70. Color blanco transparente. Textura áspera, corte heterogéneo, con aspecto de pocas impurezas.

\section{1. (04.36.47P.40984). Lámina. UE Superficie}

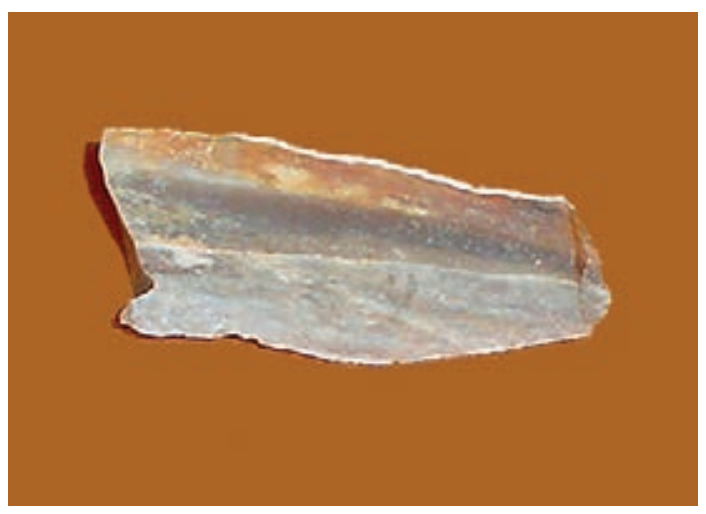

Figura 71. Muy particular, formada en cuatro bandas muy bien diferenciadas: color carne transparente, negro, gris-beige y beige blanquecino. Córtex fino de color rosáceo. Suave al tacto y con aristas bien identificadas.

12. (04.36.39E.40959). Lasca retocada. UE 1438

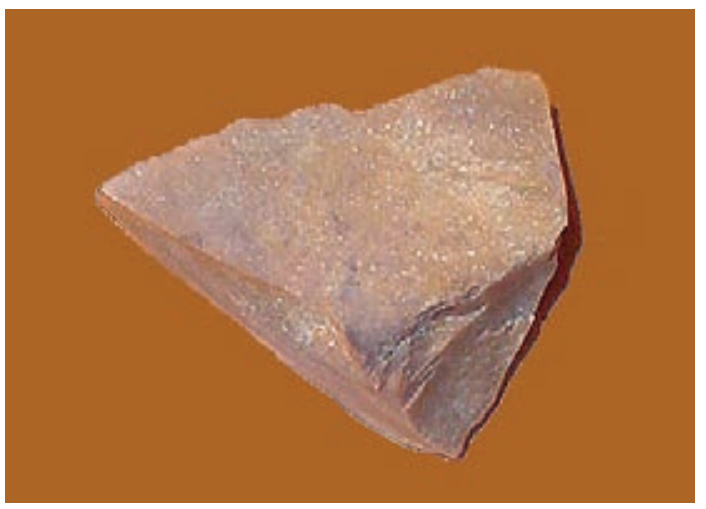

Figura 72. Color marrón claro, textura muy áspera, con abundantes manchitas blancas. No aparecen restos de córtex ni geodas. Corte muy limpio aunque con zonas muy poco definidas. Presenta algunas zonas con restos de haber sido quemada. 
13. 04.36.39C.39881. Lasca. UE 1397

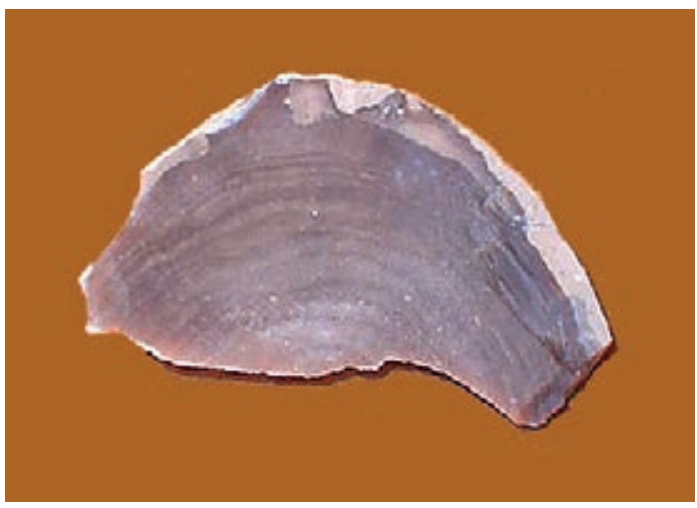

Figura 73. Negro con el corte muy limpio con bandeados que van dibujando la forma del nódulo. Córtex fino blanco muy intenso.

Tras una primera aproximación ocular, se pueden sacar las siguientes conclusiones:

- Predominio del sílex negro, liso al tacto, con una fractura muy recta, con un tipo de córtex muy fino, blanco y liso. Parece, por los materiales que hemos podido ver, que se trata de un material obtenido de pequeños nódulos.

- Existencia en grandes cantidades de otro tipo de sílex de color beige, podría tratarse del descrito anteriormente pero altamente patinado.

- Presencia de un sílex bandeado, en círculos concéntricos, de color marrón oscuro y textura lisa.

- Localizamos un tipo muy particular, formado en diferentes bandas de colores muy diferen-

\section{04.36.41C.39902. Lasca. UE 1397}

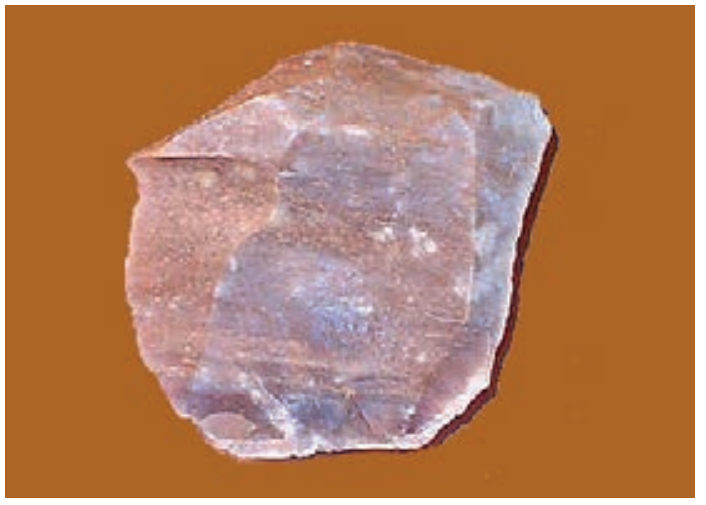

Figura 74. De color marronáceo con abundantes manchas de color blanco, con aspecto bandeado, muy patinada en blanco, de tacto seco, con aristas irregulares.

tes, la pieza tipo es la 04.36.47P.40984, con un córtex muy fino de color rosáceo.

- Como viene siendo habitual en niveles epipaleolíticos/mesolíticos, se identifica la presencia de abundantes piezas alteradas por acción del fuego, presentan coloraciones negras y rojizas, craquelados, desconchados, etc.

En cuanto al primero de los sílex identificados, se ha podido determinar por su presencia tanto en nódulos como en núcleos, restos de talla y artefactos. De manera muy clara aparece con cortes muy frescos así como patinados por acción de la tierra o por su permanencia dentro de algún fuego.

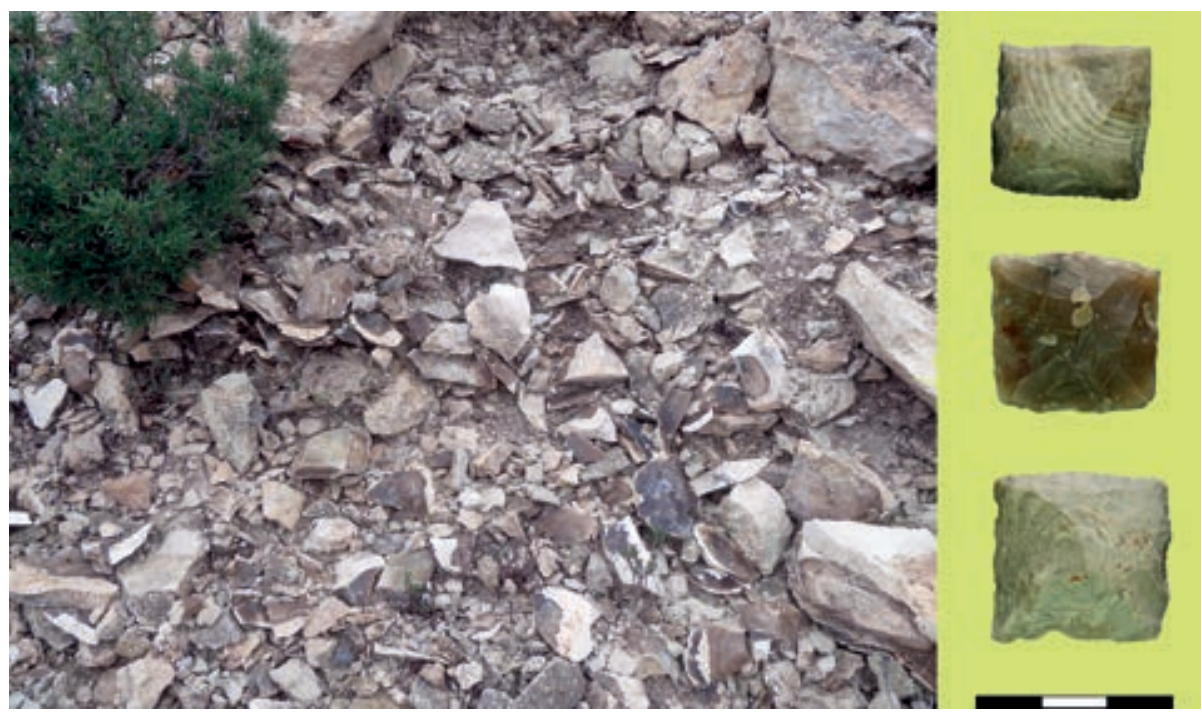

Piedras de fusil y densa concentración de lascas y restos de talla al pie del Covacho de Cabezo Negro (Botorrita). Es un ejemplo de la utilización del llamado «sílex de Botorrita» en épocas recientes para la producción de este tipo de piezas. Se han documentado explotaciones masivas en los términos de La Muela, Muel, Botorrita, Jaulín y Fuendetodos que datan de los siglos XVIII e inicios del siglo XIX. 


\section{Estudio láminas delgadas}

Sobre una selección se ha procedido a la realización de láminas delgadas y a una identificación de los elementos-traza más importantes para poder llegar a identificar el origen de estos materiales relacionándolos, a ser posible, con los localizados durante el proceso de prospección.

En este sentido, presentamos los resultados de identificación de las láminas delgadas.

\section{1. (13061)}

Presenta anillos de Liesegang, con restos de ostrácodos y algas charáceas, y alguna cementación de cuarzo fibroso. Se trata de un microcuarzo de grano muy fino.

Es una MP de ambiente de formación típico lacustre.

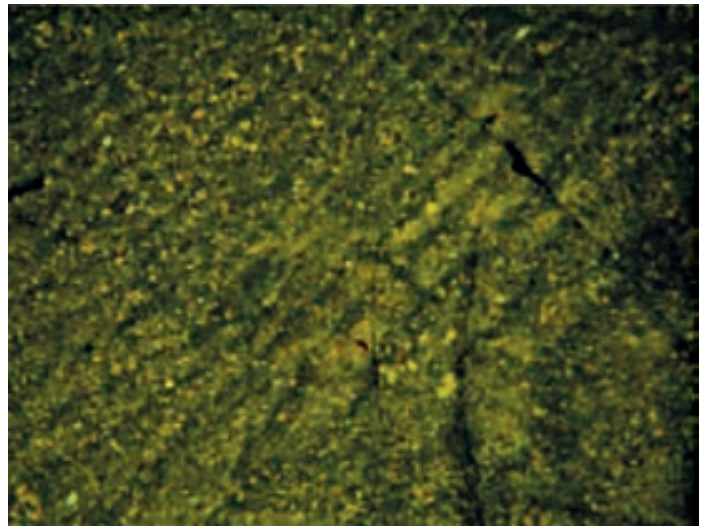

Figura 75. General.xpl. 10X.

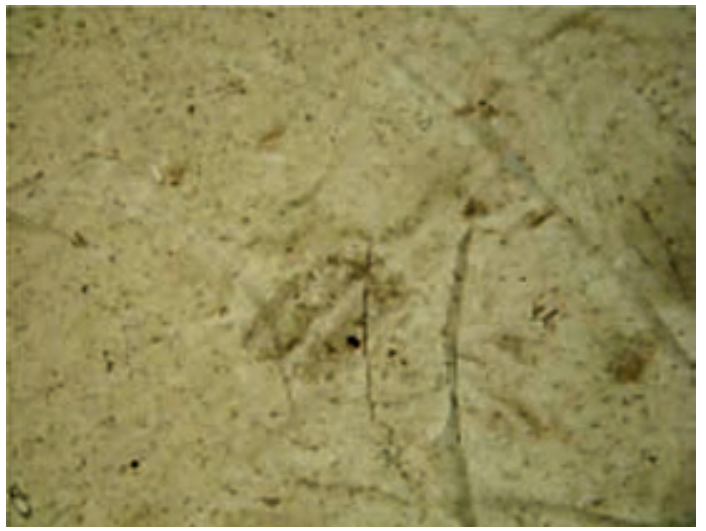

Figura 76. General.ppl.10X.

\section{2. $(13188)$}

Presenta anillos de Liesegang, ostrácodos y algas charáceas, también se ve algún granito de arena detrítica.

Se trata de un microcuarzo muy fino, típico de ambiente lacustre.

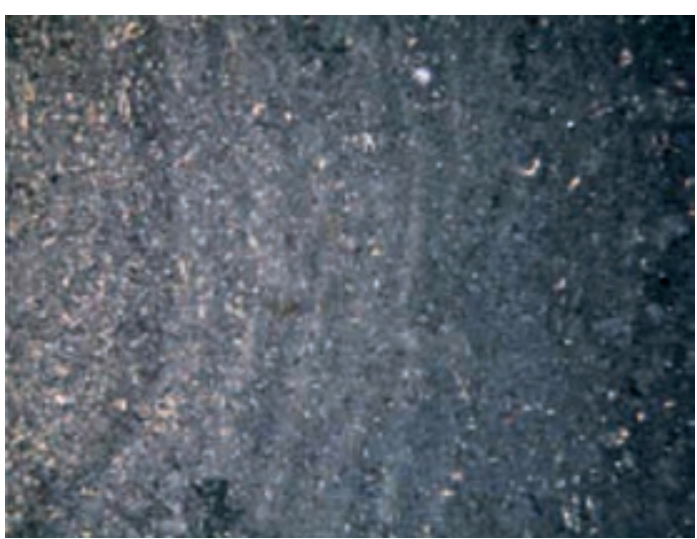

Figura 77. General.xpl.10X.

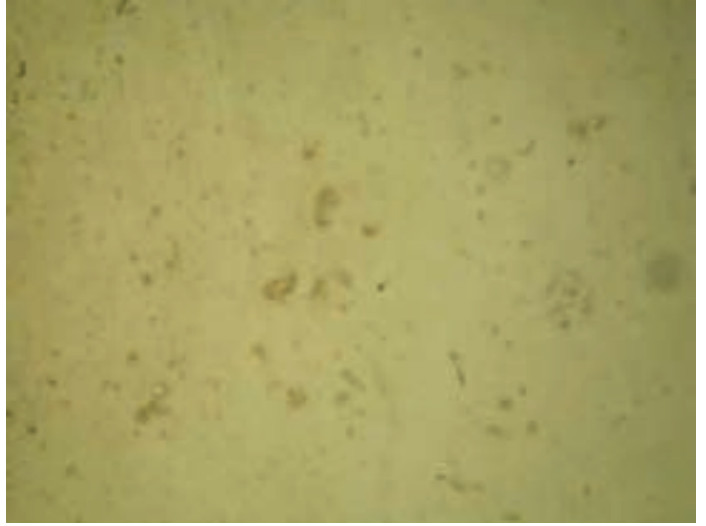

Figura 78. General.ppl. 10X. 
3. (40992)

Sílex de grano muy fino, microcuarzo, granos de arena detrítica, tipo limo. Presenta ostrácodos aunque menor contenido en bioclastos y una textura más brumosa.

Se trata de un sílex de tipo lacustre.

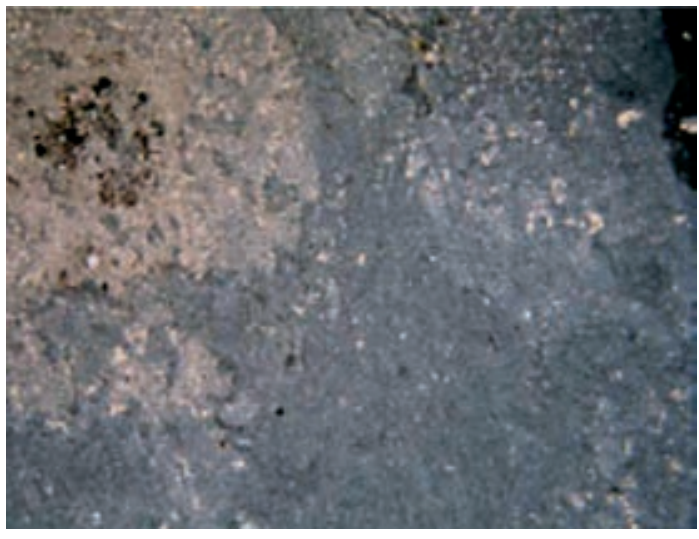

Figura 79. General. xpl. 10X.

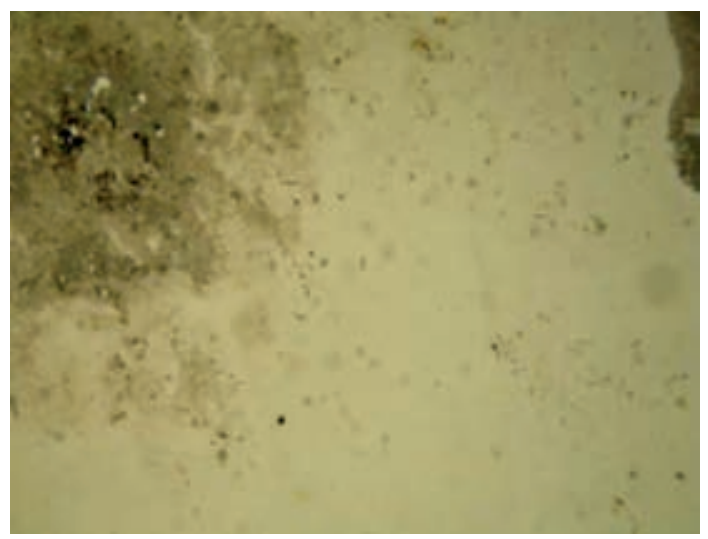

Figura 80. General.ppl. 10X.

4. (40984)

Sílex ligeramente bandeado, presenta pocos ostrácodos, granos de cuarzo detrítico y pocas impurezas.

Se trata de una materia de ambiente lacustre.

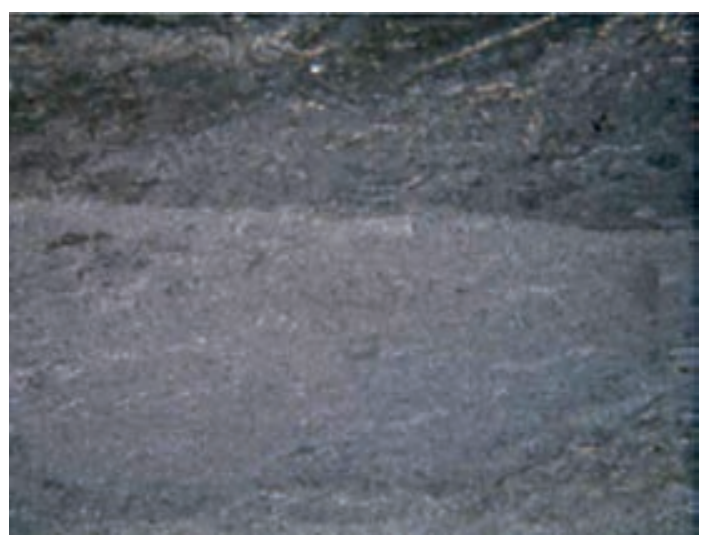

Figura 81. General.xpl. 10X.

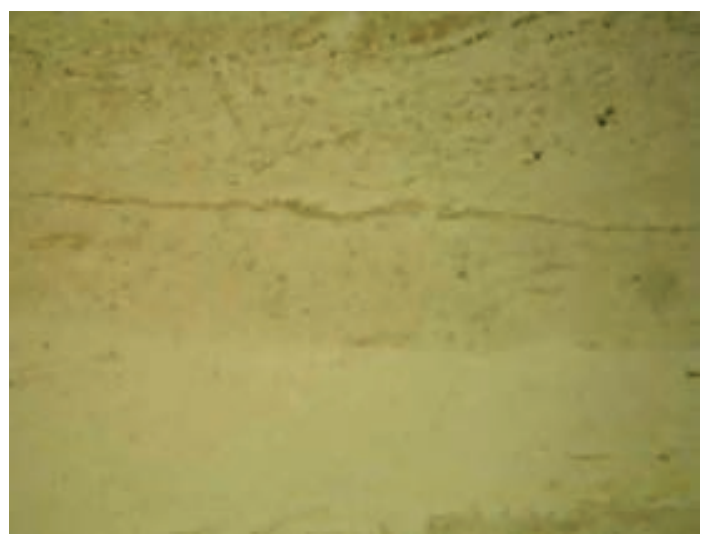

Figura 82. General.ppl. 10X. 
RAÚl LEORZA ÁLVAREZ DE ARCAYA. Estudio de las materias primas líticas

5. (40959)

Muestra ligeramente alterada. Presenta granos de arena detrítico tamaño limo, ostrácodos y charáceas, así como oxidaciones de alteración (puntos negros) postdeposicionales.

Sílex de ambiente lacustre.

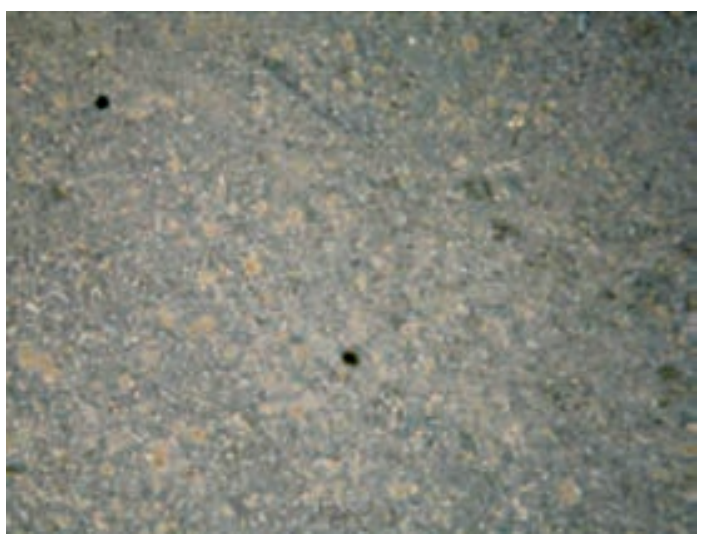

Figura 83. General.xpl.10X.

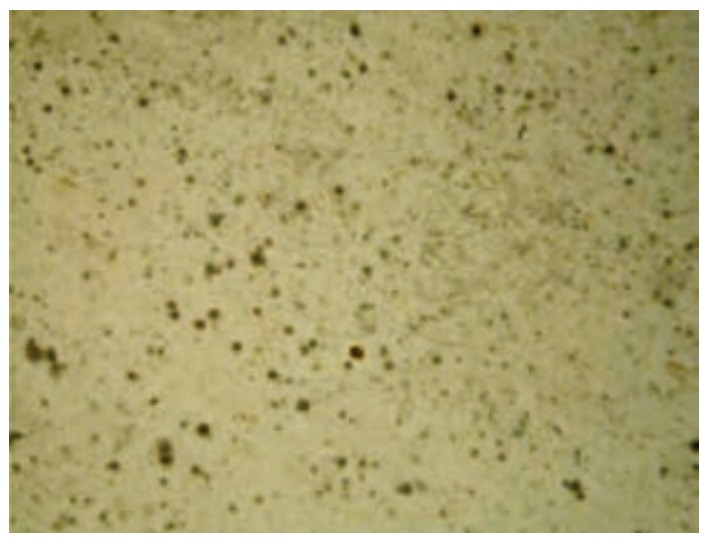

Figura 84. General.ppl. 10X.

6. (40952)

Sílex de grano fino, con presencia de ostrácodos, charáceas, granos de arena detrítico tamaño limo. Muestra más grumosa.

Materia prima típica de ambiente lacustre.

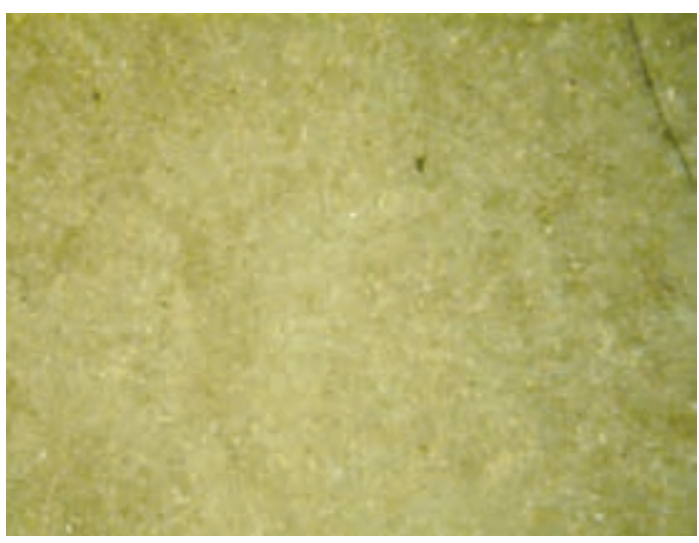

Figura 85. General.xpl. 10X.

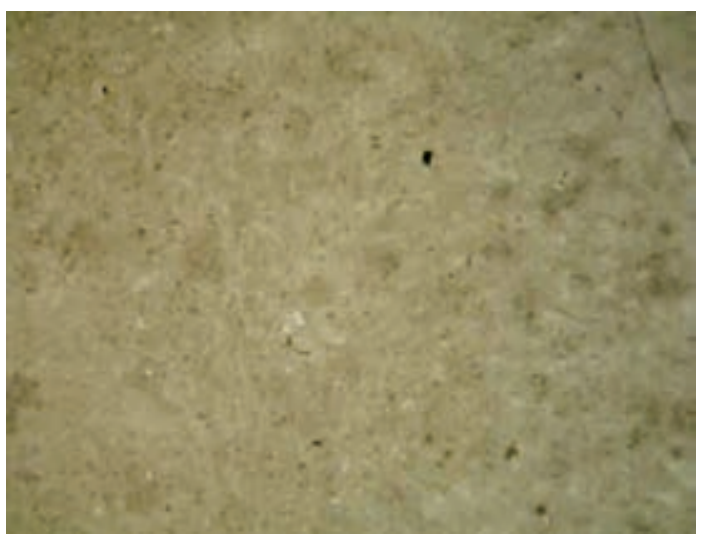

Figura 86. General.ppl. 10X. 
7. (40002)

Sílex de grano muy fino, microcuarzo, no se aprecian bioclastos (ostrácodos, charáceas); se trata de un sílex limpio, de textura muy fina, pero del mismo tipo de los anteriores.

De ambiente lacustre.

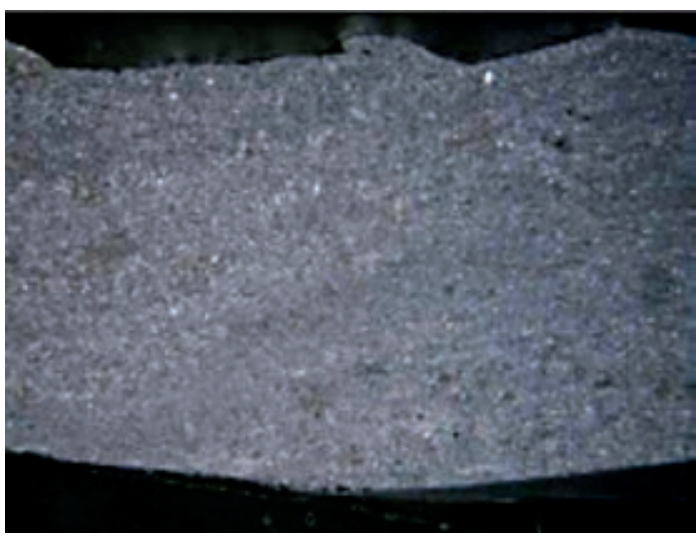

Figura 87. General.xpl.10X.

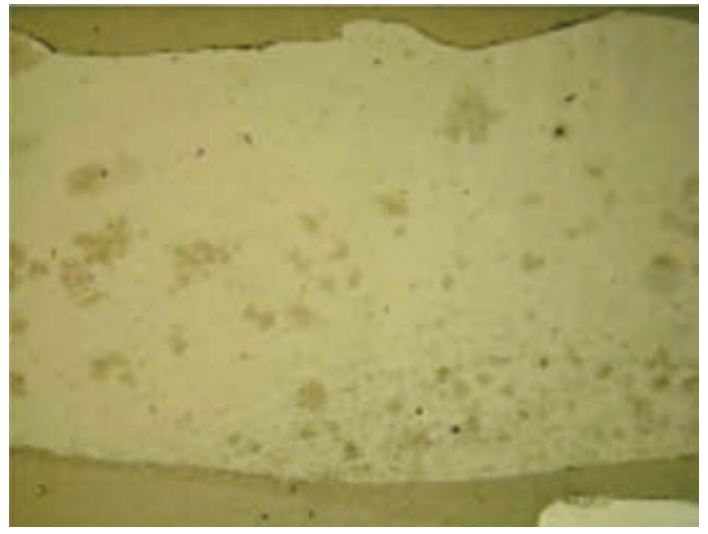

Figura 88. General.ppl. 10X.

8. (39902)

Sílex bandeado, microcuarzo de tamaño muy fino, aparecen bioclastos dispuestos en laminación paralela perpendicular a las paredes.

Materia prima de ambiente lacustre.

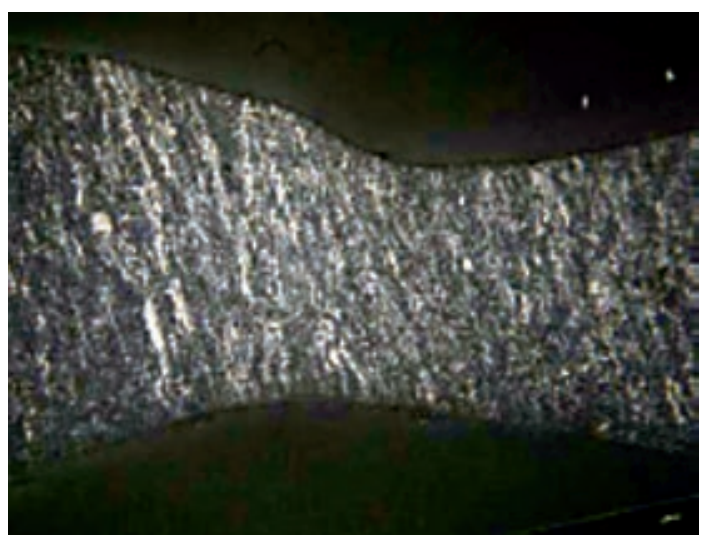

Figura 89. General.xpl. 10X.

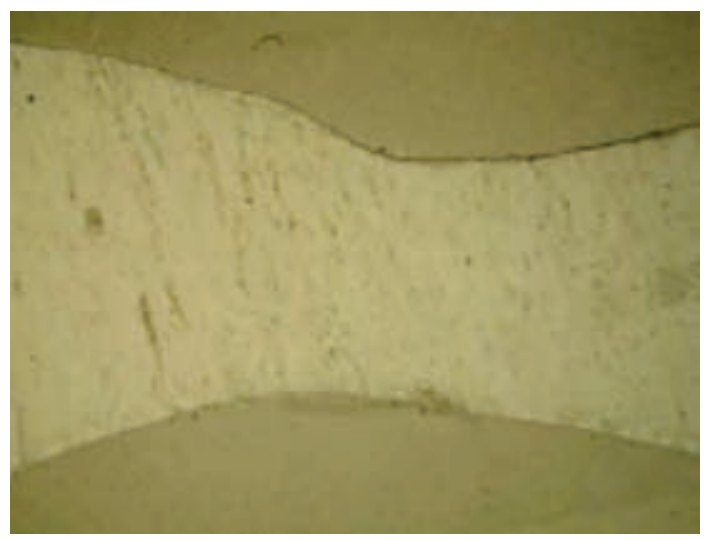

Figura 90. General.ppl. 10X. 
RAÚl LEORZA ÁLVAREZ DE ARCAYA. Estudio de las materias primas líticas

9. (39881)

Presenta anillos de Liesegang, sílex de grano fino con presencia de muchos bioclastos y granos de cuarzo detríticos.

Material de ambiente lacustre.

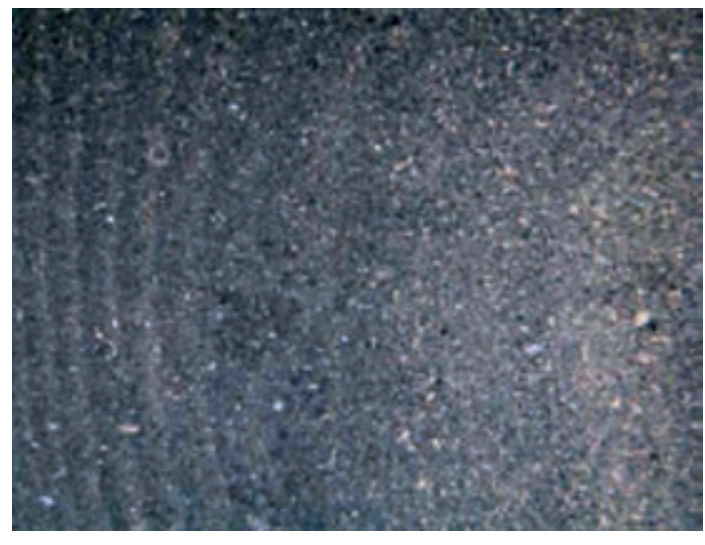

Figura 91. General.xpl.10X.

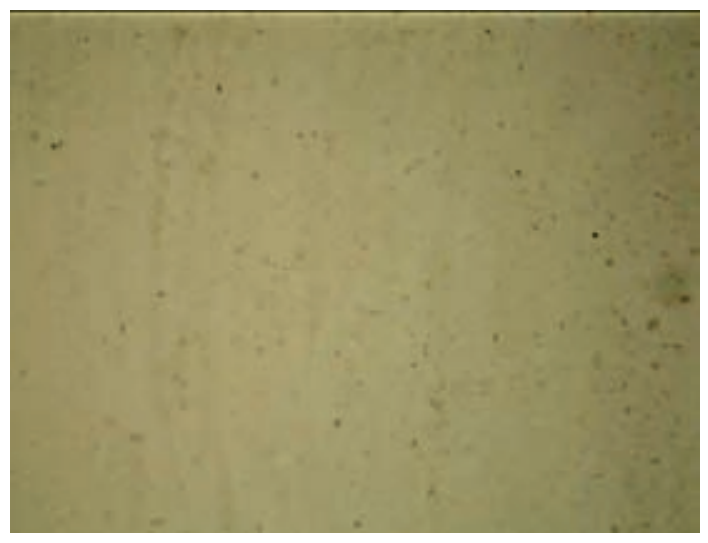

Figura 92. General.ppl. 10X.

10. (39821)

Material de grano fino, con bioclastos y granos de cuarzo. Presenta un poco de porosidad y algo más de purezas carbonatadas. Los poros entre 0,1-0,2 mm (100-200 $\mu \mathrm{m})$ de diámetro.

Sílex de ambiente lacustre.

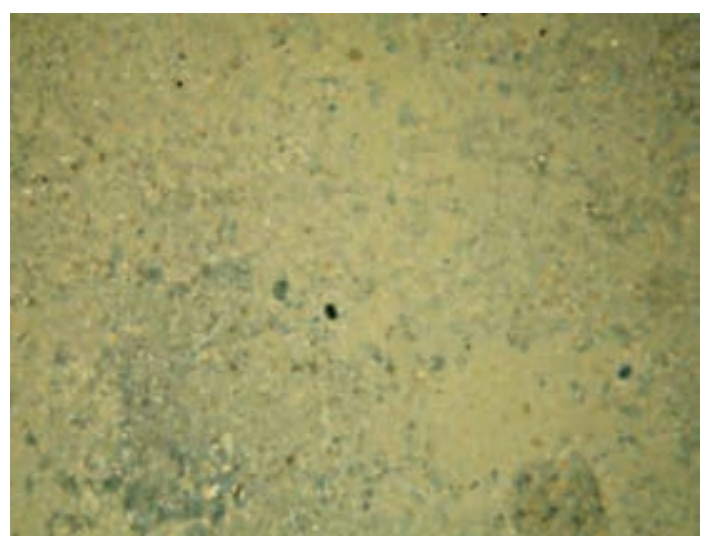

Figura 93. General.xpl.10X. 


\section{1. (39767)}

Microcuarzo alterado de manera postdeposicional, presenta gran porosidad muy alterada, bioclastos de ambiente de formación lacustre.

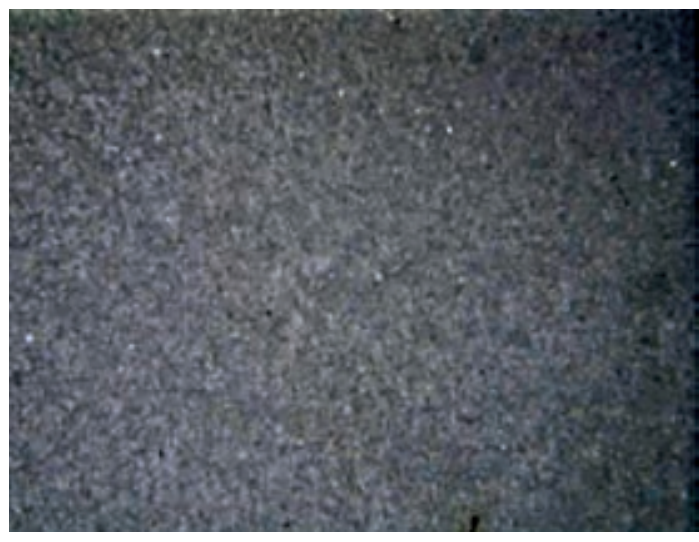

Figura 94. General.xpl.10X.

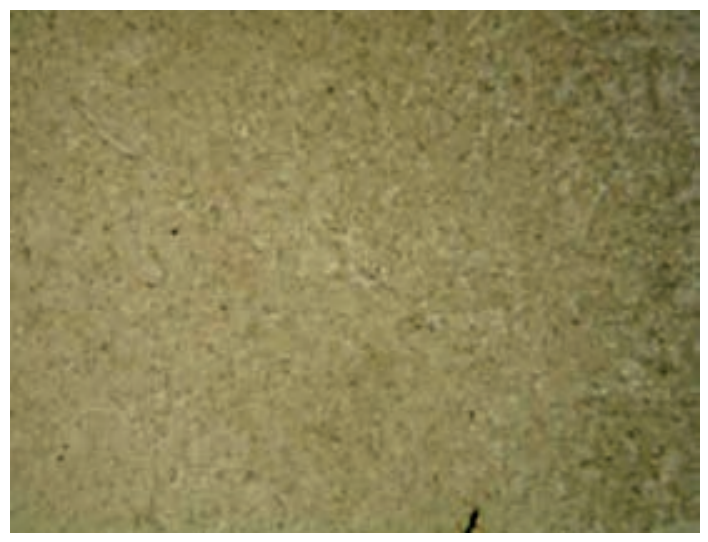

Figura 95. General.ppl. 10X.

\section{2. $(39670)$}

Sílex de grano finísimo de microcuarzo, materia prima muy fina. No presenta ni granos de arena, ni impurezas, ni bioclastos, prácticamente puro.

Sílex de ambiente de formación lacustre.

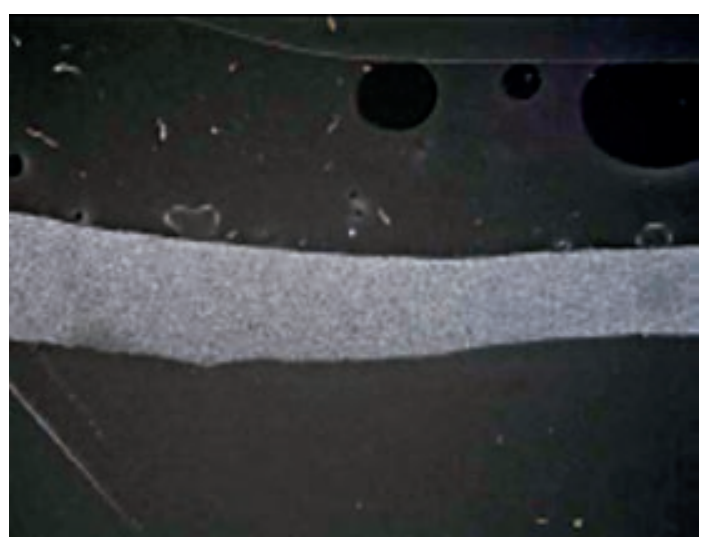

Figura 96. General. xpl. 10X.

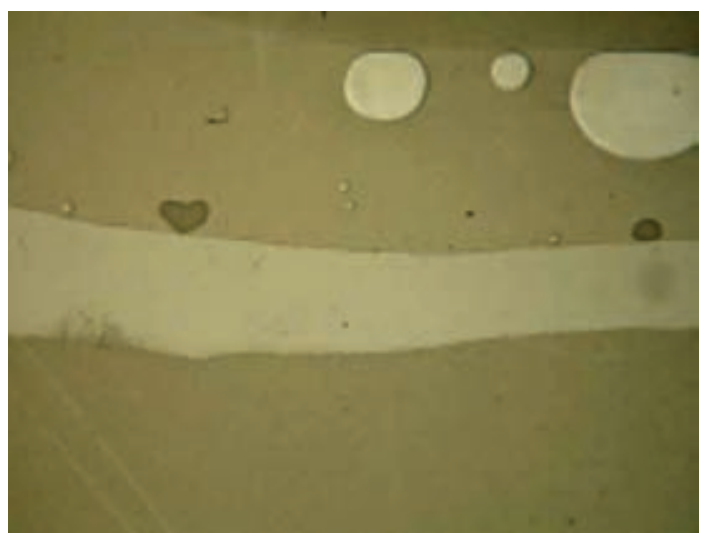

Figura 98. Detalle.xpl.50X.

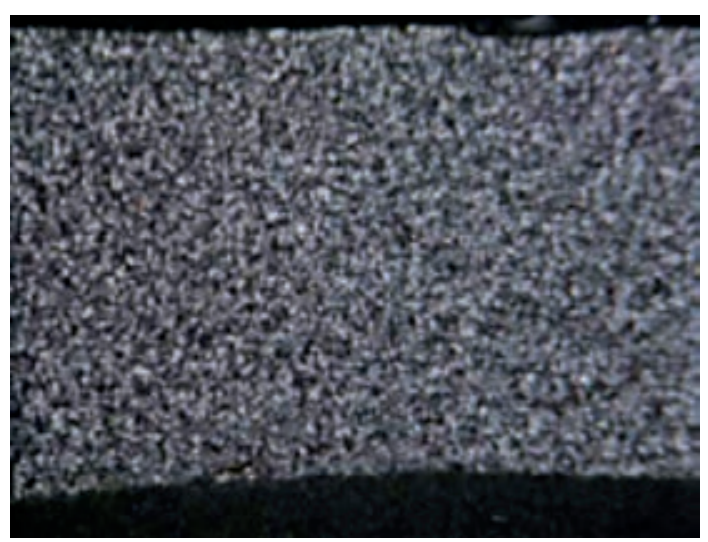

Figura 97. General.ppl. 10X.

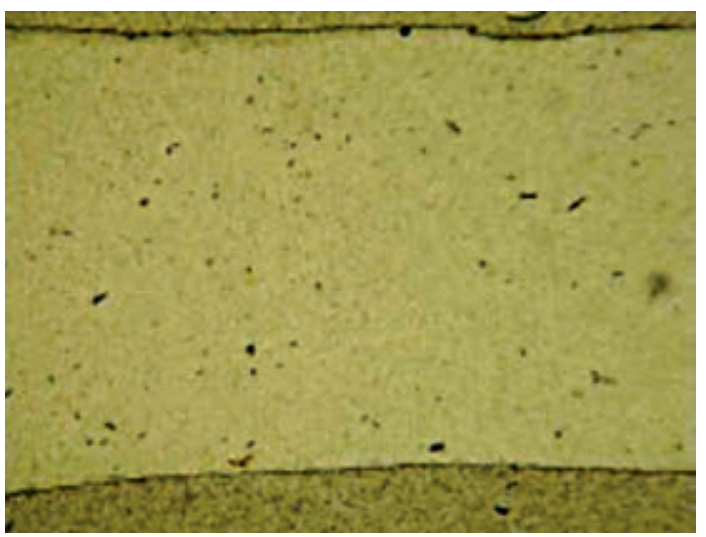

Figura 99. Detalle.ppl. 50x. 
RAÚL LEORZA ÁLVAREZ DE ARCAYA. Estudio de las materias primas líticas

\section{3. (38995)}

Cuarzo detrítico de grano fino, presenta bioclastos, similar a lo visto hasta ahora.

Sílex de ambiente de formación lacustre.

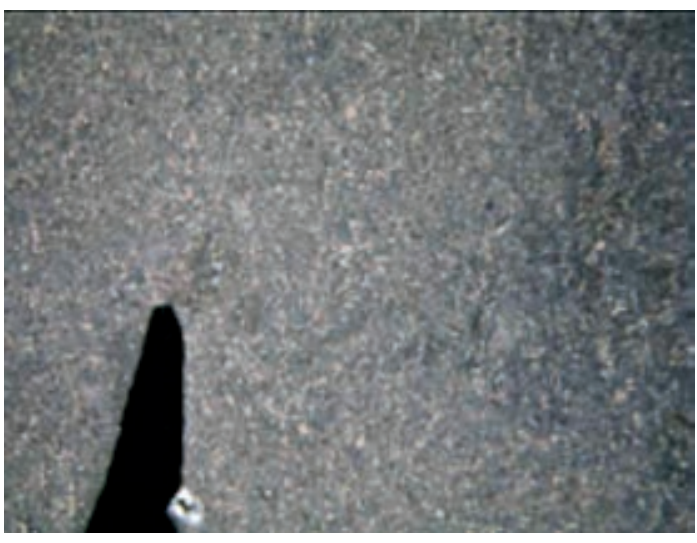

Figura 100. General.xpl.10X.

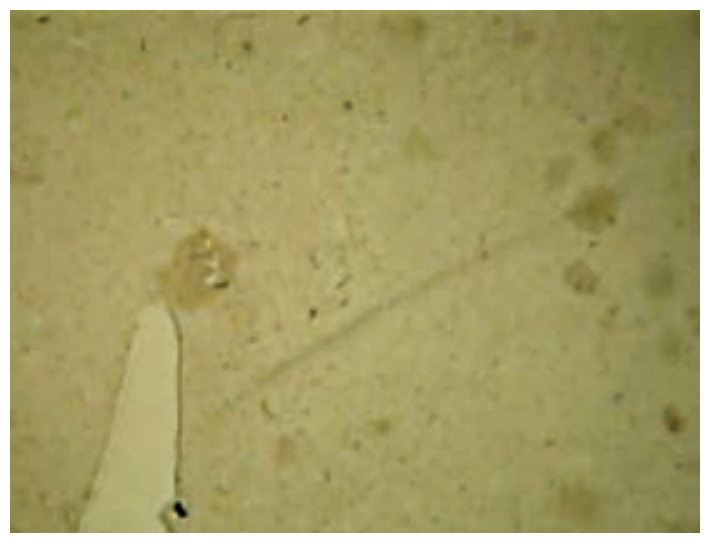

Figura 101. General.ppl. 10X.

14. (38994)

Presenta anillos de Liesegang, bioclastos (ostrácodos y charáceas), granos de arena de tamaño fino tipo limo. Sílex de ambiente de formación lacustre.

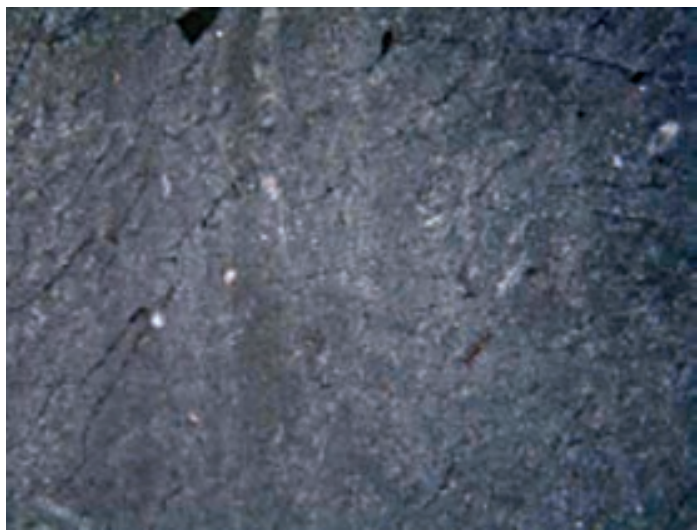

Figura 102. General.xpl.10X.

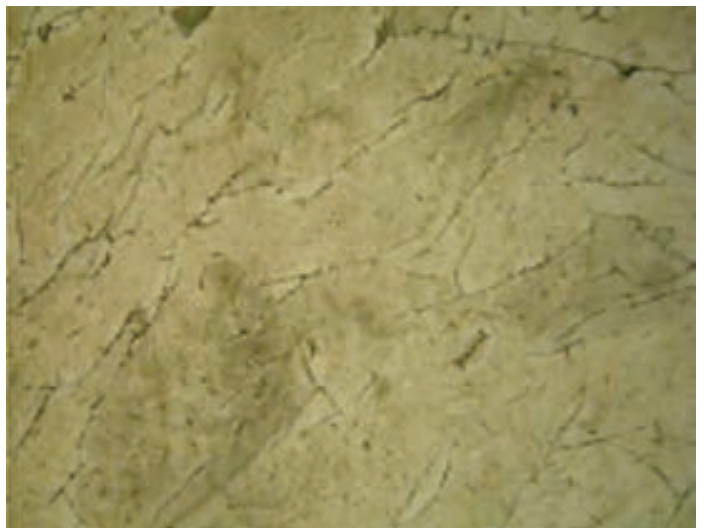

Figura 103. General.ppl. 10X. 


\section{Consideraciones sobre el análisis}

La conclusión más significativa es que todos los materiales proceden de un ambiente de formación lacustre y todas las muestras corresponden a sílex de grano muy fino, prácticamente microcuarzo, con granos de arena detrítico, tipo limo ( $<100 \mu \mathrm{m}-0,1 \mathrm{~mm}-)$. Todas las muestras pertenecen al denominado Sílex de Botorrita.
Igualmente, la práctica totalidad (una sola excepción, 39679) presenta frecuentes restos de bioclastos (lo cual nos da su origen lacustre), fundamentalmente ostrácodos (fig. 104) y charáceas (fig. 105). Además, se ha podido documentar la presencia habitual de anillos de Liesegang (fig. 106).

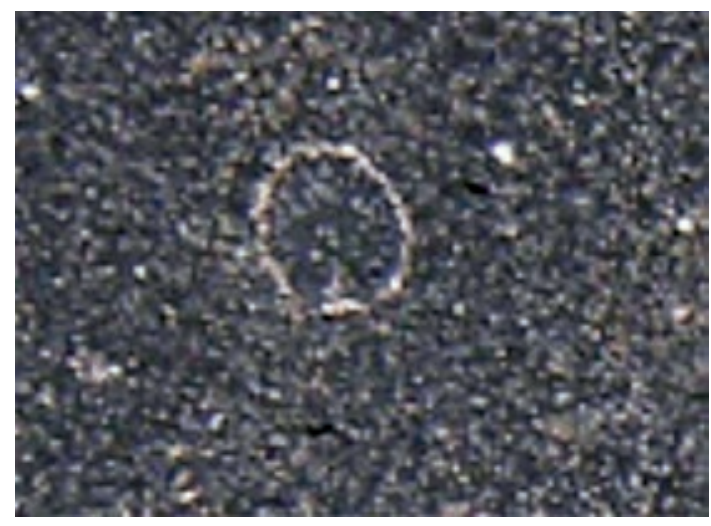

Figura 104

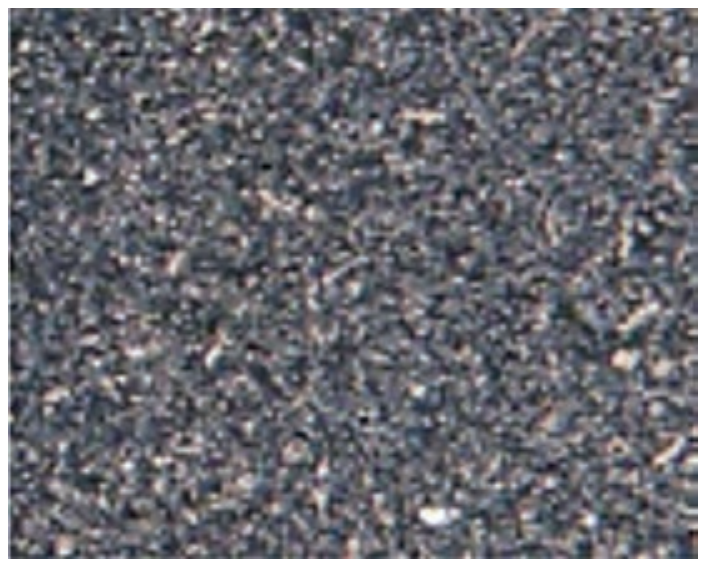

Figura 105

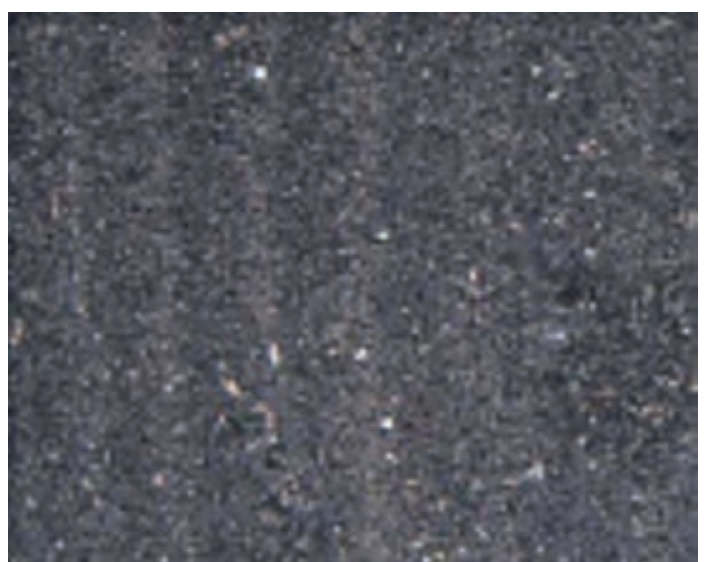

Figura 106 


\subsubsection{CONSIDERACIONES FINALES}

Una vez estudiados los materiales «geológicos» - procedentes de prospección- y «arqueológicos» - procedentes del yacimiento- sobre lámina delgada podemos afirmar la existencia de un solo grupo de MP conocido como «sílex de Botorrita». Este tipo de material presenta unas particularidades que se repiten en los dos grupos analizados (geológicos y arqueológicos).

En cuanto a los primeros, podemos afirmar que se trata de material continental, con una génesis muy próxima a su ambiente de formación: lacustre y palustre. Los lacustres presentan bioclastos, ostrácodos y algas charáceas (que se repiten en todos los materiales arqueológicos). En cuanto a los palustres, solamente podría darse un ejemplar que sería la MP 9 aunque debemos apuntar que no se trata de una muestra clara.

Con todos estos datos podemos decir que los sílex que se localizan en el entorno del yacimiento

\section{Material geológico / Material arqueológico}

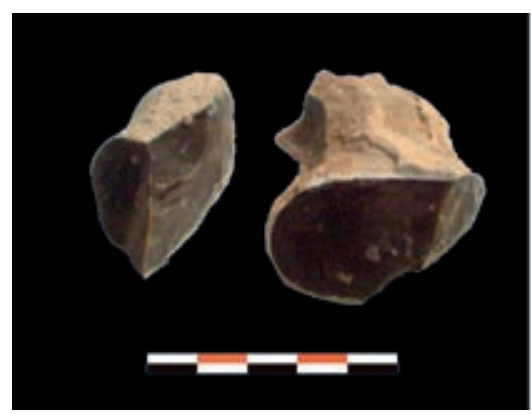

MP 12

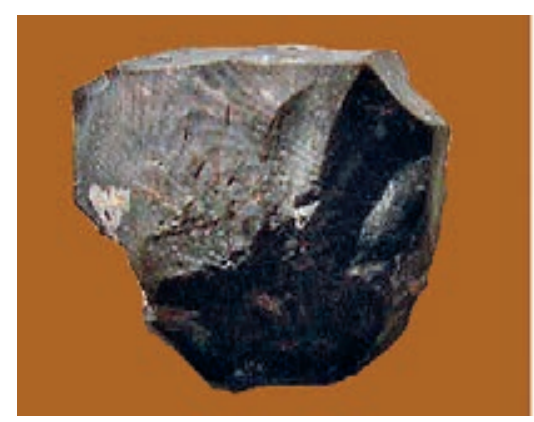

13061

En esta comparativa (MP12/13061), podemos ver la presencia de los anillos de Liesegang, así como abundantes restos de ostrácodos y charáceas. Muchas de estas evidencias son perceptibles en la misma muestra sin necesidad de del Cabezo de la Cruz son de tipo lacustre, de muy buena calidad y fácilmente recolectables por las gentes que ocuparon este asentamiento, dado que se pueden localizar en las inmediaciones en forma de riñones (nódulos) sueltos en el campo (posición secundaria), encajados en roca y en forma de tablas (tabulares) de grandes dimensiones en posición primaria.

En lo que respecta a los segundos (arqueológi$\cos )$, los criterios de clasificación han sido los mismos que en los anteriores en cuanto a componentes aloquímicos, tamaño de grano y ambiente genético.

Tenemos un tipo de sílex de ambiente lacustre con amplia presencia de bioclastos como ostrácodos y charáceas, al igual que nos sucedía con los geológicos, con un tamaño de grano muy fino, prácticamente microcuarzo, con granos de arena detrítica de tipo limo (<100 $\mu \mathrm{m}-0,1 \mathrm{~mm}-)$. Estos materiales representan la práctica totalidad del material recogido en el yacimiento.

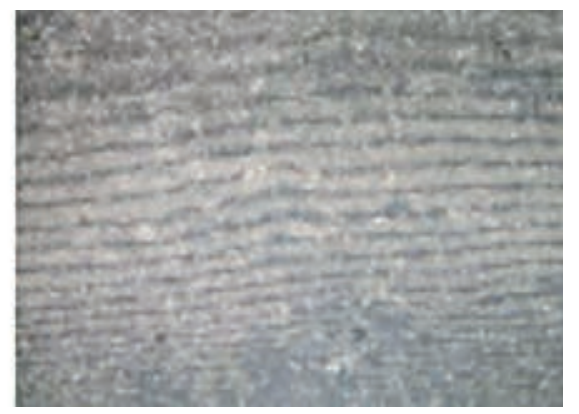

MP 12 lámina delgada

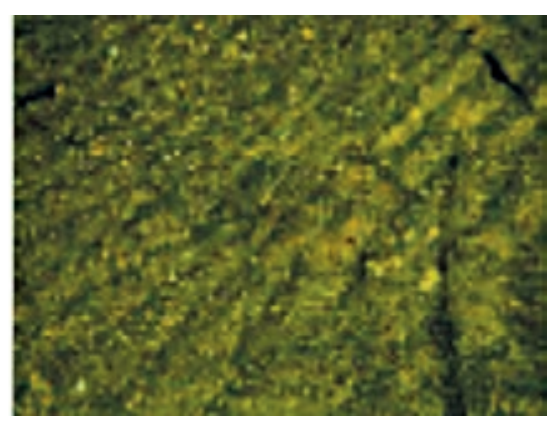

13061 lámina delgada

una lámina delgada, caso de los anillos, muy evidentes en estos dos. Como se puede apreciar, el tipo de color y el corte coinciden, se trata de un sílex muy negro; suponemos que el tipo de córtex sea el mismo. 


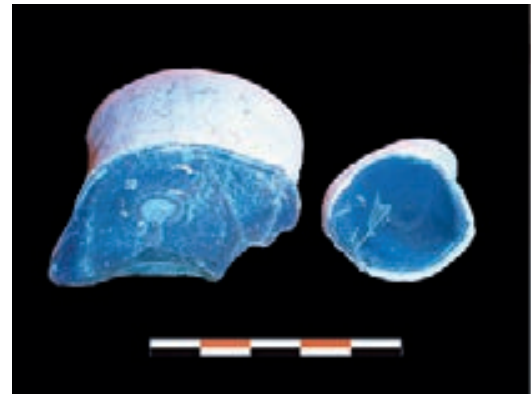

$M P 4$

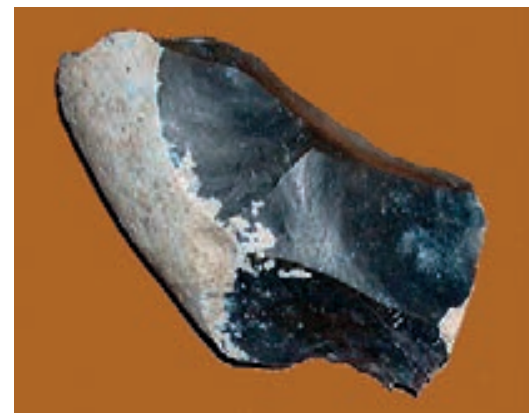

13188

Como sucede en la comparativa MP4/13188, se trata de dos muestras muy similares, en las que se ha podido comparar incluso el tipo de córtex que es idéntico. Sobre lámina delgada se pueden

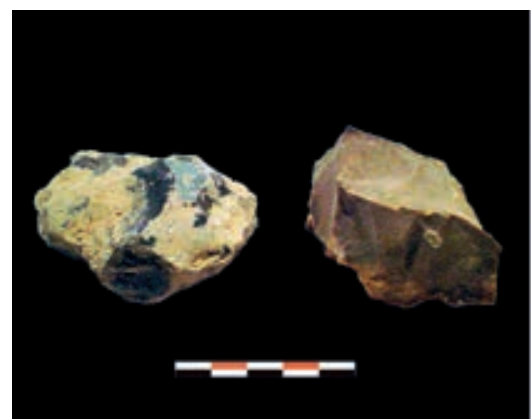
$M P 8$

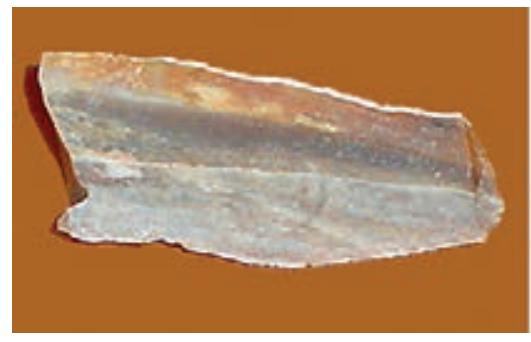

40984

A pesar de que parece se trate de un sílex muy diferente al resto de lo que tenemos, la muestra 40984 se comporta al igual que la MP 8 (por identificarlo con una MP muy similar).

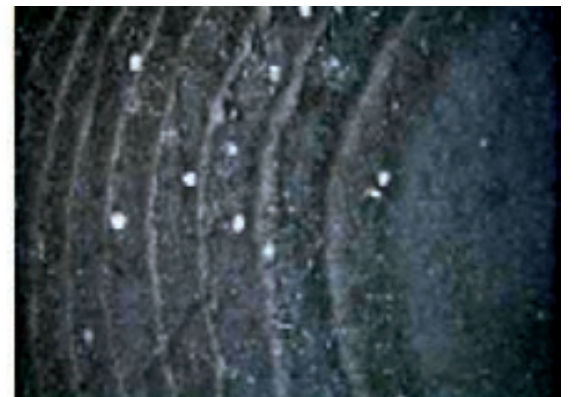

MP 4 lámina delgada

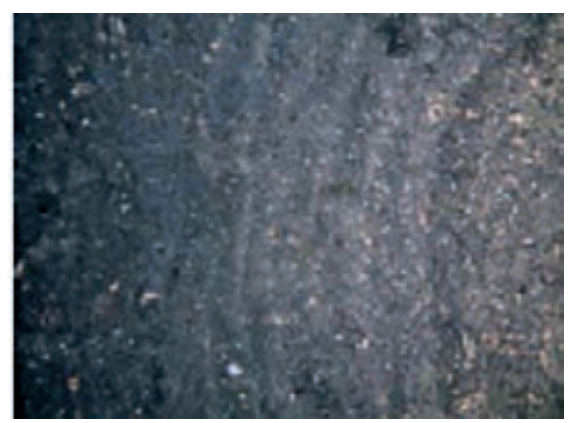

13188 lámina delgada

ver los anillos de Liesegang y las secciones de las algas charáceas y los ostrácodos que son esos pequeños puntos que relucen.

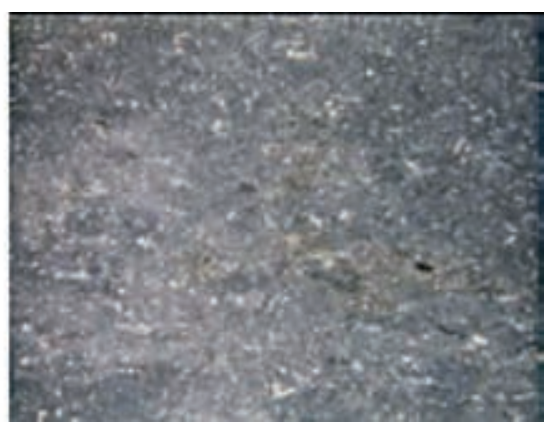

MP 8 lámina delgada

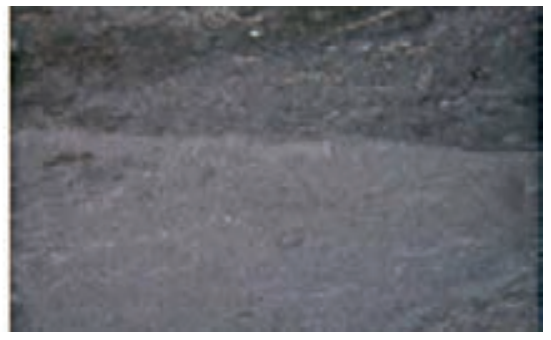

40984 lámina delgada

Con presencia de pocos ostrácodos y ligeramente bandeado. Ocurre lo mismo con la MP 8, sílex tabular, aunque con una mayor presencia de bioclastos. 


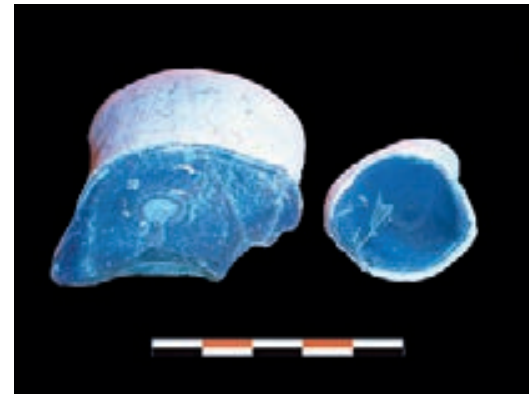

$M P 4$

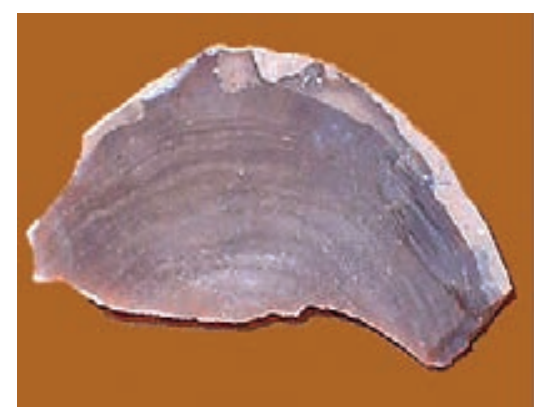

39881

MP4 y 39881 son muestras muy similares, en cuanto a composición en bioclastos en lámina delgada, así como en aspecto exterior, córtex, anillos

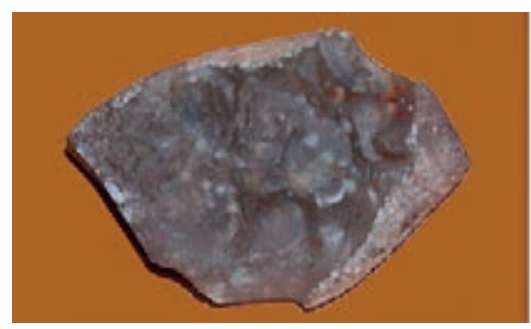

40002

La muestra 40002, aunque guarda alguna similitud con MP8, corresponde a un sílex de grano muy fino, con ausencia de casi todo, prácticamente puro, para el que no hemos encontrado semejanzas evidentes. Quizás se trate de sílex alóctono que traen a principios de la campaña estacional.

\section{El aprovisionamiento}

La hipótesis principal de este estudio es el uso, prácticamente exclusivo, de lo que conocemos como sílex de Botorrita. Este tipo de sílex se puede recolectar en forma de riñones y tablas en las inmediaciones del cabezo. Se localiza en posición primaria en ambas riberas del Huerva, descartando el posible uso de otros materiales. Aun así se da la presencia de materiales alóctonos aunque muy residuales.

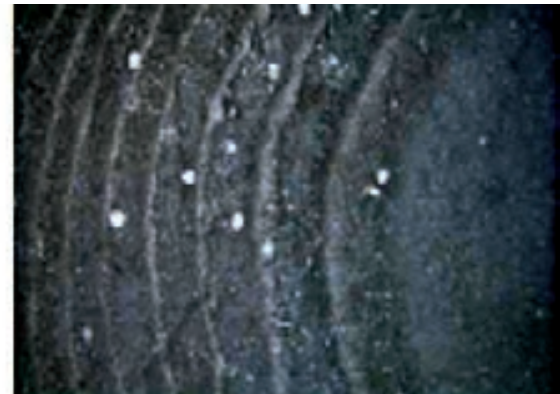

MP 4 lámina delgada

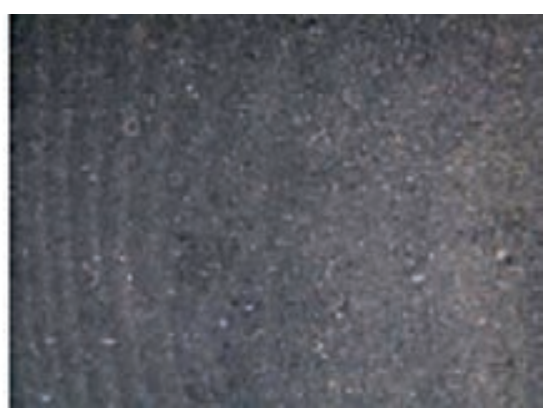

39881 lámina delgada

de Liesegang. Se trata de una muestra clara de lo que conocemos como sílex de Botorrita. De origen lacustre.

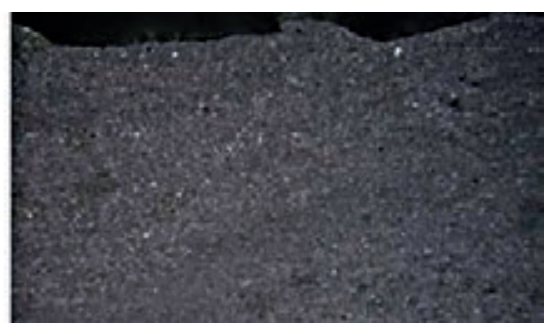

40002 lámina delgada

Dentro de las muestras arqueológicas, solamente hemos podido documentar una que se sale de lo general, la 40002, que parece otro tipo de sílex aunque se trate de un material igualmente lacustre, sin impurezas y de la misma factura que los anteriores.

Aunque no hemos podido documentar actividades mineras de este período, no podemos descartar un tipo de recolección mixto: por un lado, el aprovechamiento de todo tipo de nódulos localizados en superficie y el acceso a puntos conocidos por ellos donde la extracción de la roca era relativamente fácil o segura. Suponemos que la recolección de materiales en superficie sea el procedimiento más habitual de acopio de sílex para su talla puesto que son abundantes los puntos de afloramiento de este material en las inmedia- 
ciones del cabezo. En este sentido debemos notar un proceso geológico de movimiento de tierras que pone al descubierto los nódulos de sílex. El material geológico encajado en roca lo hemos podido localizar en las partes altas y medias de la Plana de Zaragoza, así como en la Plana de La Muela; estos materiales, con el tiempo, se precipitan hacia la parte baja de las vales y los glacis en forma de riñones fácilmente recuperables.

De este proceso tenemos varios ejemplos muy claros como son los riñones de sílex encajados en calizas que hemos denominado MP 4 y los nódu- los de sílex denominados MP 12; el primero es un ejemplo claro de material encajado en roca en la parte media-alta de la Plana de Zaragoza y el segundo es un riñón localizado en la parte baja de esta plana, en el principio de una val. Los dos corresponden a un mismo tipo de sílex con el mismo córtex, el mismo color y la misma textura en la identificación macroscópica; en el proceso de microscopía nos han dado las mismas características: muy patentes los anillos de Liesegang, gran presencia de bioclastos como las algas charáceas y los ostrácodos; sílex finísimo, criptocuarcítico.

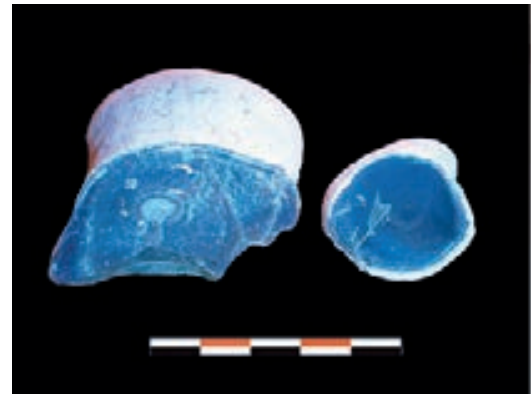

$M P 4$

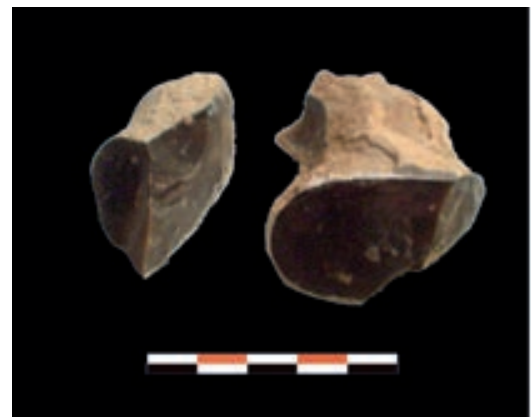

MP 12

Este ejemplo refuerza esta idea del aprovisionamiento de este tipo de material en posición secundaria, más rentable desde el punto de vista del aprovechamiento de los recursos, puesto que no se pierde mucho tiempo en la actividad minera.

En resumen, tenemos una serie de materiales arqueológicos que responden a un uso del medio inmediato, el más cercano al yacimiento del Cabezo de la Cruz. Se lleva a cabo un aprovechamiento de los recursos de MP cercanos, fácilmente localizables en la Plana de La Muela y en la Plana de Zaragoza y en todas las vales y glacis circundantes, a una y otra ribera del Huerva.

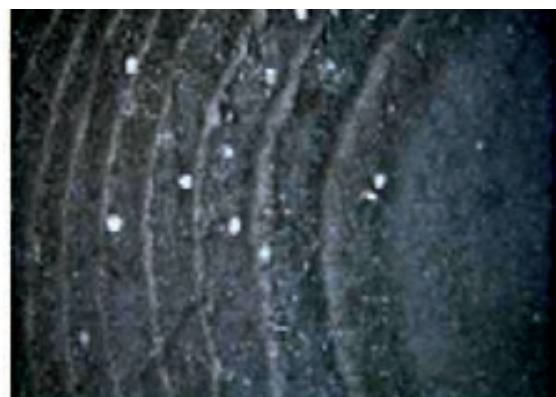

MP 4 lámina delgada

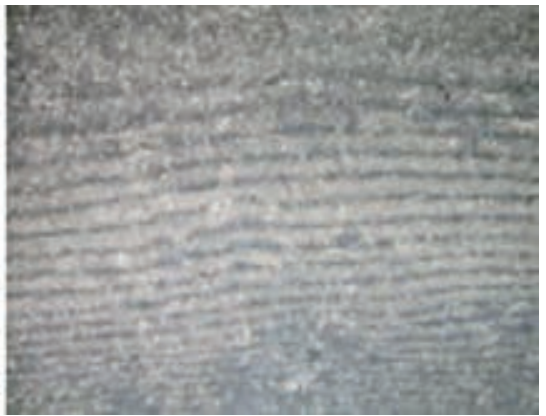

MP 12 lámina delgada

Se usa, por lo que sabemos, exclusivamente un tipo de sílex, el denominado sílex de Botorrita; se trata de una materia prima terciaria, de origen lacustre con importante presencia de bioclastos (algas charáceas y ostrácodos fundamentalmente) y donde son bastante patentes los anillos de Liesegang. Esta MP se puede localizar en las vales y glacis cercanos al yacimiento en posición secundaria, así como en la ribera del río en una última fase; y de la misma manera se puede localizar en la parte media-alta de las dos grandes planas a uno y otro lado del río, la Plana de Zaragoza y la Plana de La Muela, en las formaciones Montes de Castejón y San Caprasio que allí se desarrollan. 


\section{BIBLIOGRAFÍA}

IGME. 1980: Mapa Geológico de España. 32. Zaragoza. Escala 1:20 000. Ministerio de Industria y Energía. Madrid.

IGME. 1998: Mapa Geológico de España. 383, Zaragoza. Escala 1:50 000. Ministerio de Industria y Energía. Madrid.

MAZO, C. y Cuchí, J.A. 1992: «Sílex y prehistoria. Análisis mineralógico de muestras silíceas de Huesca y Zaragoza». Bolskan 9: 9-50.

MiNISTERIO DE FOMENTO. 2003: Mapa Topográfico Nacional de España. Hoja 383-III. La Muela, escala 1: 25000 .

- , 2003: Mapa Topográfico Nacional de España. Hoja 383-IV, María de Huerva, escala 1: 25000.

- , 2004: Mapa Topográfico Nacional de España. Hoja 411-II, Jaulín, escala 1: 25000.

- , 2004: Mapa Topográfico Nacional de España. Hoja 383-I, Dehesa El Boalar, escala 1: 25000.

- , 2004: Mapa Topográfico Nacional de España. Hoja 411-I, Muel, escala 1: 25000.
ORTí, F. y ROSELL, L. 2000: «Evaporite systems and diagenetic patterns in the Calatayud Bassin (Miocene, Central Spain)». Sedimentology, 47: 665-685.

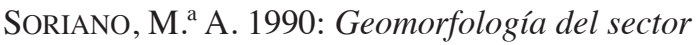
centromeridional de la depresión del Ebro. Institución Fernando el Católico. Zaragoza.

TARRIÑO, A. 1998: «Rocas silíceas sedimentarias. $\mathrm{Su}$ composición mineralógica y terminológica». KREI, 3, Vitoria-Gasteiz.

—, 2001: «Procedencia de los sílex de la industria lítica del yacimiento de Aizpea (Navarra)». Veleia, series mayor 10, Vitoria-Gasteiz.

TARriÑO, A. y NORMAND, C. 2002: «Procedencia de los restos líticos en el Auriñaciense antiguo (C4b1) de Isturitz (Pyrénées-Atlantiques, Francia)». Espacio, Tiempo y Forma. Serie I. Prehistoria y Arqueología. T. 15. UNED. Madrid.

YETANO, L.M. 1987: «La evolución geomorfológica del valle de La Huerva», Geographicalia, 2. Instituto de Geografía Aplicada, CSIC, Zaragoza. 



\section{El ecosistema}

\subsection{ESTUDIO GEOARQUEOLÓGICO}

José LuIS PEÑA MONNÉ*, VIRGINIA RUBIO FERNÁNDEZ*** Y VÍCTOR GENÉ GONZÁLEZ*

\subsubsection{El CONTEXTO GEOLÓGico Y GEOMORFOLÓGICO}

El Cabezo de la Cruz es un pequeño cerro, situado en la margen izquierda del río Huerva, que apenas destaca en relación con otros relieves similares circundantes (fig. 1). La forma y características de este relieve y su entorno es el resultado de la evolución morfológica del valle y las laderas del cerro en un ambiente morfoclimático propio de una depresión terciaria continental, con fluctuaciones climáticas holocenas de variado signo, a la que se deben los retoques más recientes.

\section{Escala geológica regional}

El yacimiento se sitúa en el sector centro-meridional de la Depresión del Ebro y muy próximo al contacto con la Cordillera Ibérica. Esta cuenca terciaria se configuró como fosa tectónica de antepaís durante el Eoceno medio, al tiempo que se elevaban las cordilleras limítrofes. Su dispositivo como cuenca endorreica durante el resto del Terciario determinó un proceso de relleno sedimentario siguiendo la clásica ordenación de facies de abanico aluvial, depositadas por los ríos procedentes de las sierras pirenaicas e ibéricas. La zona de estudio correspondería a una zona distal de formaciones detríticas finas, lutíticas y de arenas finas, depositadas en ambientes distales de baja energía, así como facies evaporíticas, formadas por yesos y sales, precipitados en ambientes

* Dpto. de Geografía y Ordenación del Territorio. Universidad de Zaragoza, <jlpena@unizar.es>.

** Dpto. de Geografía. Universidad Autónoma de Madrid, <virginia.rubio@uam.es>. someros de lagunas y charcas salobres (sebkjas) del centro de la cuenca.

A lo largo del Mioceno inferior-medio (Pérez et al. 1988), las formaciones yesíferas se extendieron por el sector central de la cuenca constituyendo los yesos de la Formación Zaragoza (Quirantes 1978; Riba et al. 1983). Finalmente, el Mioceno y el inicio del Plioceno culminan con formaciones carbonatadas, también de ambientes de charcas y lagunas discontinuas en el centro de la cuenca endorreica (Pérez et al. 1988). Estas litologías forman parte de la Unidad Tectosedimentaria (UTS) 5 de Muñoz et al. (2002) y Pardo et al. (2004).

En el Plioceno comienza un proceso de apertura de la cuenca hacia el mar (García-Castellanos et al. 2003), que va a configurar la red fluvial cuaternaria, con un eje principal formado por el río Ebro y una red de afluentes ibéricos y pirenaicos que tendrán en conjunto el mar Mediterráneo como nivel de base. La consecuencia de este exorreísmo de la cuenca ha sido la progresiva incisión de la red fluvial en los sedimentos terciarios, que se han visto fuertemente sobreexcavados por amplios valles que cortaron las calizas miocenas, compartimentándolas en muelas o plataformas estructurales individualizadas (Gutiérrez y Peña 1994; Peña y Lozano 2004) que actualmente conforman los relieves más elevados de la región, cercanos a los 700 m.s.n.m. (fig. 1).

$\mathrm{Al}$ alcanzar la incisión las series blandas lutíticas y yesosas inferiores, los valles se fueron ampliando de forma más rápida y durante al evolución cuaternaria se generaron acumulaciones importantes de terrazas fluviales, glacis y conos laterales que tapizaron parcialmente los sedimentos terciarios siguiendo pulsaciones marcadas principalmente por los cambios climáticos cuaternarios. Estas acumulaciones aluviales son de gran importancia para reconstruir la evolución regional durante el Cuaternario. 


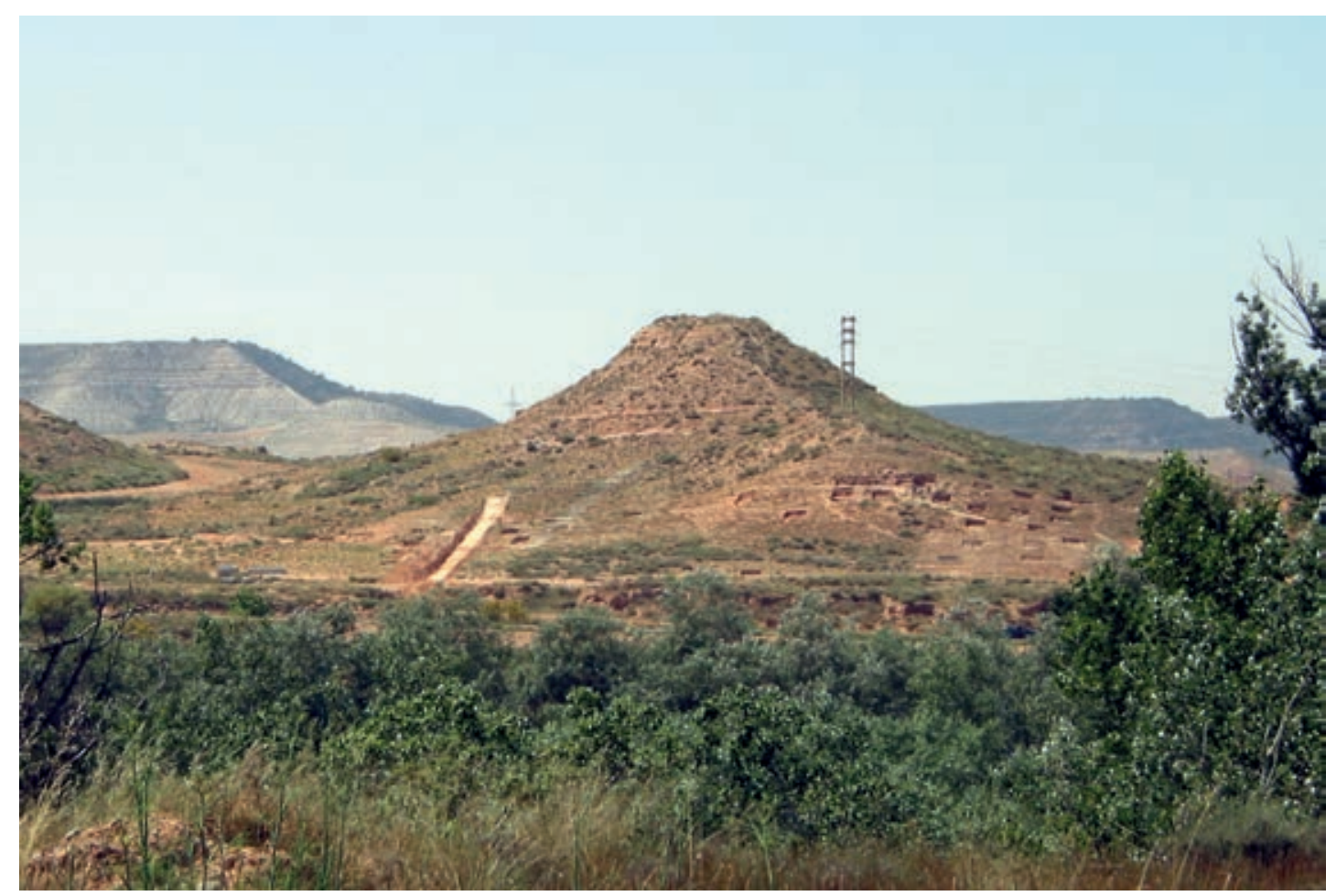

Figura 1. Vista general de la ladera-cono en la que se sitúa la cata arqueológica.

\section{Escala local}

Dentro de este contexto geológico general, se pueden diferenciar varias unidades de relieve, que forman el entorno cercano al yacimiento del Cabezo de la Cruz (figs. 2 y 3 ):

Las muelas neógenas. El progresivo encajamiento del río Huerva ha generado dos plataformas calizas horizontales o muelas, una en cada margen del valle, sobreelevadas unos $400 \mathrm{~m}$ sobre el lecho del río. Estas muelas, que forman la zona de divisoria de aguas principal con los otros valles cercanos afluentes del Ebro, son la Plana (695 m) y La Muela $(675$ m), ambas constituidas por superficies estructurales planas de calizas miocenas, escasamente deformadas aunque en muchos casos se observan pequeños repliegues y fracturas y huellas de aplanamientos erosivos que nos testimonian una evolución mucho más compleja. La resistencia de estas calizas determina un escarpe perimetral, fuertemente festoneado por las cabeceras de los afluentes del río Huerva que sitúan allí su cabecera. Los pequeños valles o vales que bordean el Cabezo tienen este ámbito de procedencia.

Los paleorrelieves de calizas mesozoicas. En el sector sur de la cuenca del Ebro los sedimentos terciarios no alcanzan gran espesor de tal manera que es habitual encontrar restos de afloramientos de rocas mesozoicas, principalmente calizas jurásicas, que han sido exhumadas por la red fluvial y configuran, a veces, relieves de importancia a causa de su gran dureza. Serían una muestra del paleorrelieve que los sedimentos terciarios fosilizaron durante la evolución del relleno de la cuenca. Es el caso del anticlinal de Muel, en el que se asienta esta localidad, que el río ha cortado por sobreimposición tras atravesar las series detríticas terciarias, sirviendo este estrechamiento para la construcción de la presa de Muel en época romana.

Las terrazas fluviales cuaternarias. El río Huerva sitúa su cabecera más allá de los sedimentos terciarios de la cuenca del Ebro, penetrando en las serranías de la Rama Aragonesa de la Cordillera Ibérica. Estas unidades de relieve están formadas principalmente por cuarcitas y pizarras paleozoicas, así como por los sedimentos terciarios existentes en las cuencas internas ibéricas (Calatayud-Montalbán). Por ello, una de las litologías que componen una parte importante de los depósitos detríticos acumulados en las terrazas fluviales son los materiales cuarcíticos, calizos y detríticos del área de cabecera. Desde estas sierras ibéricas, el río se dirige hacia el Norte penetrando 


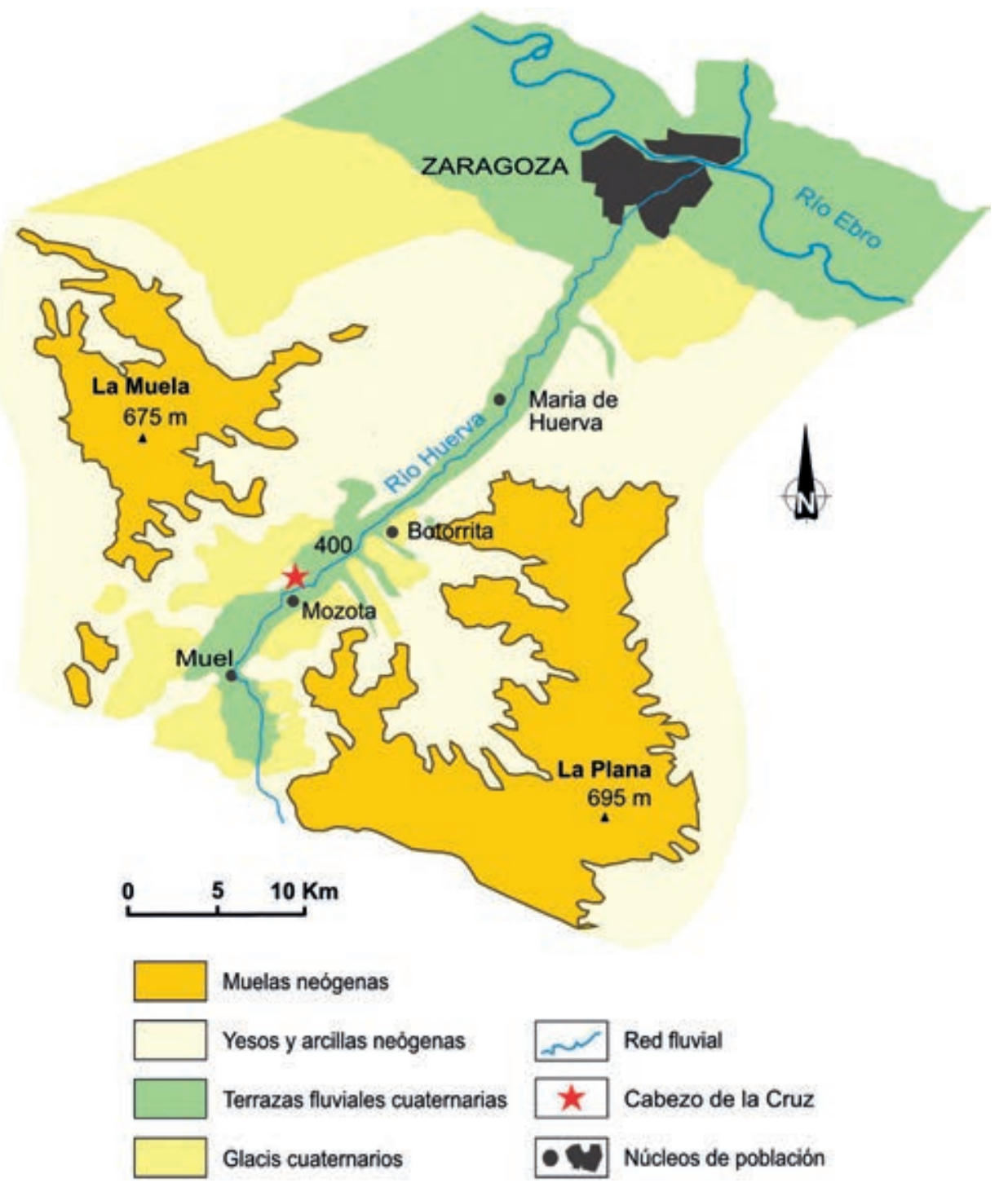

Figura 2. Elementos morfológicos del curso bajo del río Huerva.

en la depresión terciaria del Ebro, donde durante su evolución pleistocena ha excavado un valle más amplio, aprovechando la menor resistencia erosiva de sus sedimentos. Por otra parte, ha conformado un amplio sistema de terrazas compuesto de $8 \mathrm{ni}$ veles escalonados, aunque el número de etapas ha tenido distintas interpretaciones por diferentes autores, como Mensua e Ibáñez (1977), Yetano (1977), van Zuidam (1976) y Soriano (1990).

En el entorno del yacimiento hay restos de la terraza 6 , situada a unos $75 \mathrm{~m}$ sobre el cauce actual del Huerva; de la terraza 5 hay varios testimonios a unos $55 \mathrm{~m}$ sobre el río, formando pequeñas plataformas al SW del Cabezo y otros cerros aislados en la parte noroeste; la terraza 4 queda a unos
$30 \mathrm{~m}$, dando lugar a superficies más continuas y a algunos cerros, uno de los cuales es justamente el propio Cabezo; las terrazas 3 y 2 , situadas a 20 y $10 \mathrm{~m}$, respectivamente, forman banquetas amplias en ambos márgenes fluviales. Por último, el lecho de inundación está recorrido por el curso meandriforme del Huerva, que se adapta a la forma de los conos laterales holocenos.

Las terrazas se componen de espesores de 2-20 m de gravas y canales de materiales arenosos, cuyas litologías reflejan las rocas que atraviesa el río en su trayectoria, de manera que los componentes más fácilmente identificables son los ya mencionados cantos rodados de cuarcitas paleozoicas de tonos marrón, que pueden alcan- 

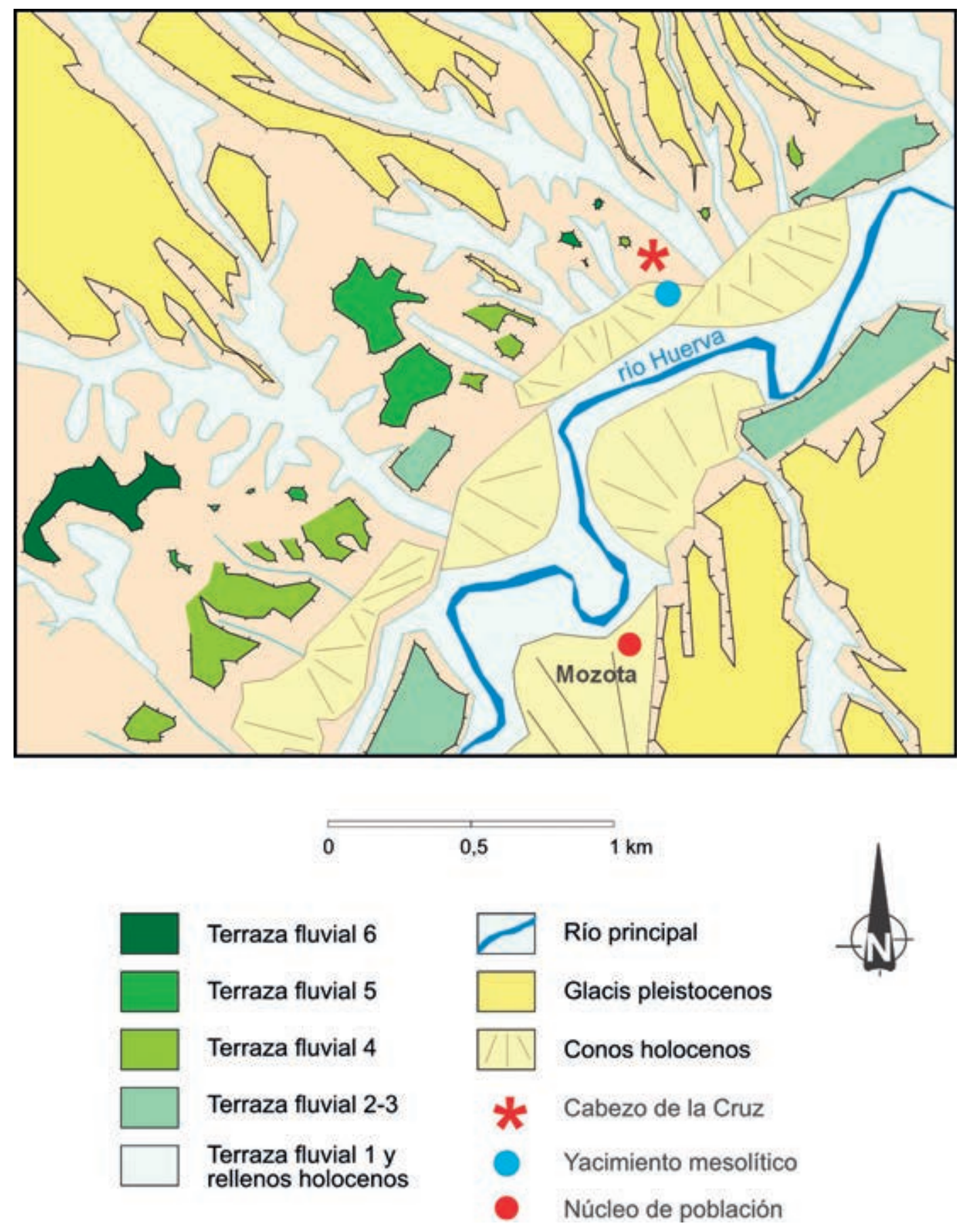

Figura 3. Esquema geomorfológico del entorno del Cabezo de la Cruz.

zar grandes dimensiones (eje mayor superior a los 25-30 cm) en las terrazas antiguas. También hay cantos de calizas mesozoicas y neógenas, así como de areniscas terciarias y mesozoicas.

Los glacis laterales. El río Huerva se ha ido desplazando durante el Cuaternario lateralmente hacia el este, por lo que ha generado una configu- ración disimétrica del valle. El margen oriental es el más abrupto y apenas conserva acumulaciones cuaternarias. Sin embargo, en la orilla izquierda u occidental, desde los escarpes de la plataforma calcárea de La Muela hay una mayor separación hasta el fondo aluvial del río Huerva, lo que permite que se produzca una gradación de relieves. 
Estos se componen de capas resistentes de yesos $\mathrm{y}$ areniscas que dan pequeños resaltes planos, y por los restos de rampas de glacis con pendiente del 2-4 \%, que fueron depositados por los cursos descendentes de La Muela y que están enlazando con las terrazas fluviales cuaternarias del río Huerva. Su composición es muy diferente a la de las terrazas, ya que predominan los cantos calizos de las plataformas miocenas, así como fragmentos de sílex; también los cantos de yeso son abundantes, especialmente en los niveles más bajos. En la mayoría de los casos, estos materiales presentan envueltas de carbonato, que cubren total o parcialmente su superficie.

Las laderas holocenas. Aunque en la zona apenas se conservan las diversas etapas de configuración de laderas regularizadas que han sido descritas en otras áreas de la cuenca del Ebro y de la Cordillera Ibérica, podemos suponer que debieron existir ya que se conservan algunas laderas residuales. Estas laderas conformaban vertientes perfectamente regulares de sedimentos que recubrían el sustrato terciario y lo protegían de la erosión, acompañadas seguramente de una destacada cubierta vegetal. Se generaron en condiciones climáticas más frías y húmedas que las actuales y han sido datadas como de finales de la Edad del Bronce y de la Edad del Hierro (Gutiérrez y Peña 1998). En la zona cercana hay que resaltar el cerro de la Visera, cerca de Botorrita, que conserva todavía este tipo de morfología y contiene material arqueológico que permite la datación indicada (Peña et al. 2004). La desaparición casi total de esta etapa acumulativa de laderas en esta zona se ha interpretado que es debida al desencadenamiento erosivo que produjo la intensa presión humana sobre el medio.

Los rellenos de valle y conos holocenos. Uno de los rasgos más característicos de la evolución holocena de este sector del valle del río Huerva son las morfologías de valles de fondo plano, que presentan sus afluentes menores («vales»); estos rellenos constituyen las zonas principales de cultivo actual por su topografía y por su constitución limosa. Por los datos existentes (Soriano y Calvo 1987; Soriano 1989; Peña et al. 1993, 1996, 2001, 2004; Ángeles et al. 2004), conocemos que esta forma plana es consecuencia del relleno durante el Holoceno de valles anteriores en forma de $\mathrm{V}$, debido al aporte de detritus trasladados desde las laderas y cabeceras de los valles. El proceso parece iniciarse en fechas anteriores al $6000 \mathrm{BP}$ aunque con un máximo de acumulación en torno a la época iberorromana (Peña et al. 1993, 1998, 2001, 2004). Estos depósitos se interpretan como de génesis antropoclimática, es decir, por coincidir condiciones climáticas favorables a la erosión con una fuerte intervención humana en las laderas antes mencionadas. Las acumulaciones de valle se prolongan en forma de conos aluviales depositados en el valle principal y que el río Huerva ha ido cortando y sorteando en su evolución reciente con trazado meandriforme.

\subsubsection{LA MORFOLOGÍA DEL YACIMIENTO}

Los elementos geológicos y geomorfológicos descritos como contexto regional y local del valle bajo del Huerva pueden ser identificados en el propio yacimiento.

El Cabezo forma un cerro alargado dominado por una cumbre superior redondeada y un escalón intermedio del que desciende un talud final hacia el fondo del valle. Los materiales aflorantes en el cerro pertenecen al Mioceno (UTS 5) y se componen de alternancias de lutitas de tonos rojizos y grises, en ocasiones margosas. Algunas trazas de yeso fibroso atraviesan las arcillas con líneas entrecruzadas de poco espesor y sin relación con la estratificación. También es posible observar algunos nódulos de sílex. Los yesos y areniscas yesíferas conforman los niveles más resistentes, que dan resaltes en las laderas, especialmente en el sur y este del Cabezo.

El cerro queda configurado en su dispositivo alargado debido a la incisión de dos barrancos paralelos laterales, que presentan la morfología característica de fondo plano o val, con rellenos importantes que en su culminación pertenecen ya a época romana, como ya es habitual en este valle (Peña et al. 2004, 2005). El sector más alto del cero estaba formado originalmente por los restos de una terraza fluvial (nivel 4) del río Huerva, observándose aún las gravas dispersas entre los restos de la construcción medieval que ocupa la cumbre, así como en sus laderas, donde se acumulan parte de los materiales erosionados de la zona alta. El escalón intermedio es consecuencia del afloramiento de niveles de yesos de facies arenosas y mayor resistencia, que permiten un resalte abrupto.

En su vertiente norte, este relieve conserva parcialmente la morfología regularizada de ladera ya indicada también en el contexto local y que en la prospección efectuada muestra contenidos 
de materiales de las edades del Bronce y Hierro. Según el modelo evolutivo señalado para el bajo Huerva (Peña et al. 2004, 2005), estas laderas corresponderían a restos de la regularización que se originó con posterioridad a la Edad del Hierro. Esta morfología debía extenderse originalmente por todas las laderas pero ha desaparecido por la erosión posterior, aunque se corresponde con algunos afloramientos observados durante la excavación arqueológica en la zona del foso de la Edad del Hierro-Época Ibérica (Peña et al. 2009).

El resto del cerro está principalmente compuesto de formas erosivas, especialmente en su sector sureste, donde ha desaparecido prácticamente el yacimiento junto con las morfologías previas sobre las que se apoyaba. Es posible también identificar algunos pequeños conos en la ladera sur, generados por pequeños barrancos que descienden hacia el valle de fondo plano del límite meridional, que contienen también cerámicas de época medieval.

Durante la etapa de prospección geoarqueológica realizada en las laderas del Cabezo, se dedicó una especial atención al corte que quedaba a una altura de $2 \mathrm{~m}$ por encima de la antigua carretera de Zaragoza-Teruel, en el límite oriental del área de excavación. El perfil entonces visible mostraba un depósito de ladera o zona distal de cono, formado principalmente por materiales finos arcilloso-arenosos, conteniendo algunos cantos de yeso y unos pocos de cuarcita. Pequeños fragmentos de sílex, sin huella de retoques, pero sin duda generados por roturas antrópicas, aparecían dispersos, con no excesiva densidad, hacia la parte media-alta del perfil. Por otra parte, la inexistencia de restos de cerámica de ninguna de las edades de ocupación del cerro nos indicaba que la ladera necesariamente tenía que ser anterior a los momentos principales de ocupación, al menos a las Edades del Bronce y del Hierro, por lo que así fue clasificada en un primer momento, siendo, por tanto, el depósito más antiguo del yacimiento.

La posterior realización de una cata en esta ladera, en una posición más cercana al cerro (fig. 4), mostró la presencia de los materiales mesolíticos, formados por sílex en un fondo de cabaña, que se situaría estratigráficamente dentro de la mencionada ladera. Del corte efectuado se ha realizado la siguiente descripción:

Nivel A. Formado por arcillas arenosas con una fuerte compactación con unos $27 \mathrm{~cm}$ de espesor.

Nivel B. Capa estrecha, de unos $5 \mathrm{~cm}$ de grosor, con abundancia de sílex, así como cenizas y carbón. Corresponde a una fase de ocupación, que por la tipología del material y la datación C14 efectuada se ha situado en el Mesolítico $(7130 \pm 130 \mathrm{BP}-7150 \pm 70 \mathrm{BP})$.

Nivel C. Arcillas arenosas con un buen número de bolsadas de cantos, que parecen indicar la existencia de procesos de arrastre por escorrentía superficial. El espesor está en torno a $35 \mathrm{~cm}$. Corresponde a una etapa de regularización de las laderas que, por su relación con otra de las catas cercanas, que contiene materiales de la Edad del

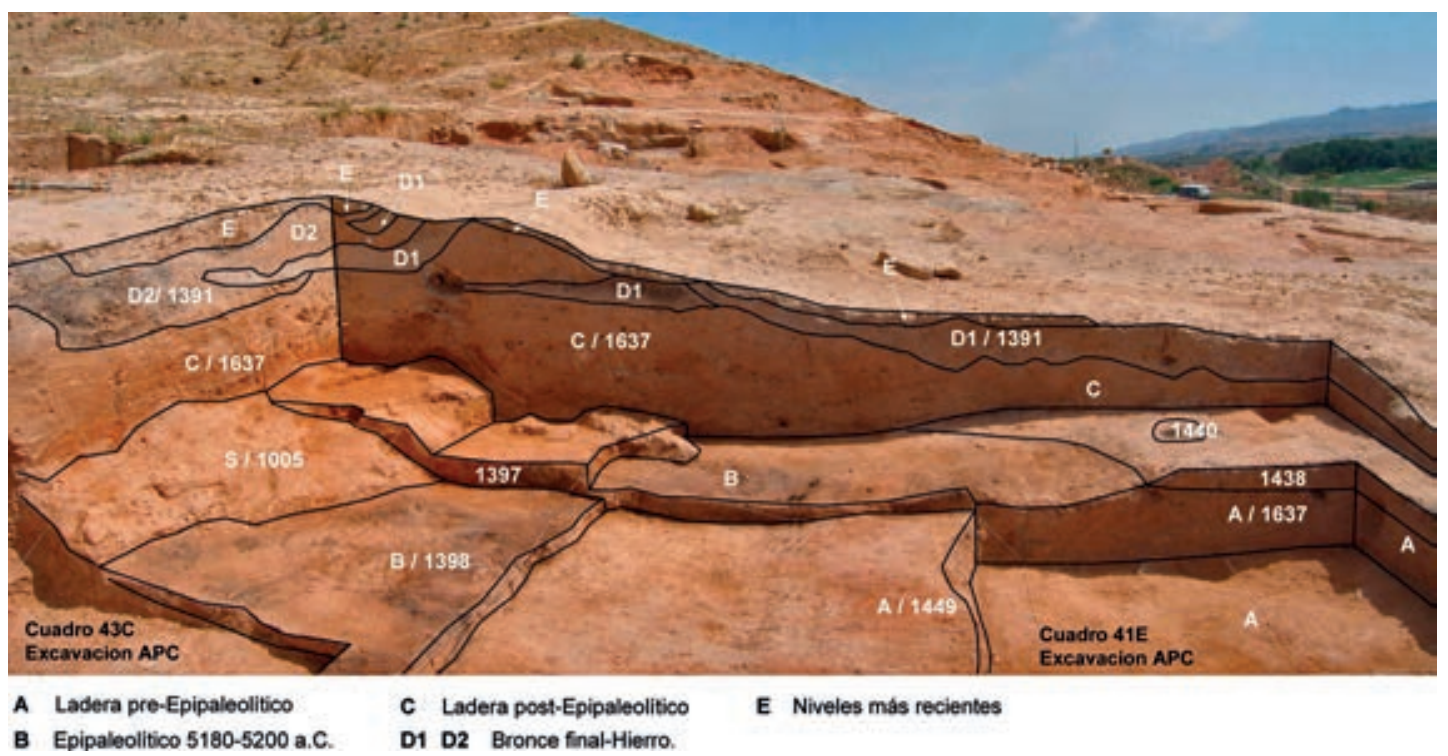

Figura 4. Niveles diferenciados en la cata con materiales mesolíticos. 
Bronce, podríamos asimilarlo a la etapa general de evolución de vertientes de edad post-Bronce.

Nivel D. Conjunto de capas discontinuas que, por su contenido en cenizas y carbones, corresponde a restos de la Edad del Bronce. Su espesor es muy variable y por término medio alcanza en torno a $15 \mathrm{~cm}$.

D1. Cenizas finas de color gris claro.

D2. Arcillas cenicientas, con restos de carbón.

Nivel E. Capa más externa que, en el perfil de la excavación, solo alcanza unos $10 \mathrm{~cm}$ aunque hay que tener en cuenta que no es la superficie original ya que ha sido fuertemente erosionada y luego aplanada en los trabajos iniciales de la propia intervención arqueológica. Corresponde a una acumulación de ladera que sellaría completamente los niveles anteriores y que es difícil de situar cronológicamente, por lo que la consideramos como de época muy reciente; por la información existente en el valle del Huerva (Peña et al.2004, 2005) y la presencia de cerámicas medievales en los conos situados al oeste del perfil efectuado, podría ser perfectamente post-medieval.

\subsubsection{CONCLUSIONES GENERALES}

\section{E INTERPRETACIÓN EVOLUTIVA}

El yacimiento mesolítico del Cabezo de la Cruz ocupa la parte basal de un cerro residual situado muy cerca del río Huerva, cuyo relieve ha sido modelado en las arcillas y yesos terciarios de la cuenca del Ebro. La cumbre del cerro conserva gravas fluviales cuaternarias depositadas por el río Huerva durante el Pleistoceno.

El paisaje del entorno del Cabezo contiene los principales elementos geomorfológicos generales de este sector del curso bajo del río Huerva, como son las plataformas estructurales de La Muela y la Plana, que forman los relieves más elevados, de los que descienden con suave pendiente las rampas de glacis cuaternarios, especialmente en la orilla occidental del valle. Los restos de las terrazas fluviales conforman pequeños cerros y mesas, constituidos por gravas del río Huerva, y una densa red de barrancos de fondo plano o vales, formadas por rellenos del Holoceno superior, bordea el yacimiento.

En un primer momento, se configuró una ladera extensa, con morfología externa de cono de materiales finos, que seguramente ocuparía el entorno este, noreste y sureste del cerro, cuya edad es anterior o contemporánea al Mesolítico, sobre la que se situaron las cabañas pertenecientes a esa época. Una nueva etapa de ladera regularizaría y cubriría estos materiales, generada durante la
Edad del Bronce o inmediatamente después. Finalmente, el yacimiento quedó fosilizado por sedimentos de ladera procedentes de la parte alta, en época posiblemente postmedieval.

Hay que resaltar la gran importancia de este yacimiento, conservado casualmente bajo una fuerte capa de sedimentos que lo ha protegido. Lo más habitual es que los yacimientos de dicha época hayan desaparecido tras la intensa erosión que caracteriza la región a partir del 6000 BP, registrada en los rellenos de valle de las Lenas y de la Morera (Peña et al. 1993, 1996, 2001, 2004). La interpretación de los autores citados es que dichos sedimentos son correlativos de la intervención inicial del hombre sobre el medio, en condiciones ambientales favorables para la erosión. Pero nunca se había encontrado una muestra de la presencia humana in situ en este sector de la cuenca del Ebro, lo que contradice algunas ideas sobre la ausencia de ocupación para tales épocas.

\section{BIBLIOGRAFÍA}

Ángeles, G., PEÑA, J.L. y LongARES, L.A. 2004: «Cartografías de reconstrucción paleoambiental y riesgo geomorfológicio del Holoceno superior en el valle del río Huerva (Depresión del Ebro)». En Peña, J.L. et al. (eds.): Geografía Física de Aragón. Aspectos generales y temáticos, Universidad de Zaragoza e Institución Fernando el Católico. Zaragoza, 303-314. <http://age.ieg.csic.es/fisica/ docs/06-memoria.htm>.

GARcía-CASTEllanos, D., Vergés, J., GASPARESCRIBANO, J. y ClOETINGH, S. 2003: «Interplay between tectonics, climate and fluvial transport during the Cenozoic evolution of the Ebro Basin (NE Iberia)». Journal of Geophysical Research, 108 (B7), ETG 8, 1-18.

GutiÉRreZ, M. y PEÑA, J.L. 1994: «La Depresión del Ebro». En Gutiérrez. M. (dir.): Geomorfología de España, Rueda. Madrid, 305-349.

—, 1998: «Geomorphology and Upper Holocene climatic change in Northeastern Spain». Geomorphology, 23: 205-217.

MensuA, S. e IBÁÑEZ, M.J. 1977: «Terrazas y glacis del centro de la Depresión del Ebro». III Reunión Grupo Trabajo Cuaternario. 18 p. Zaragoza.

Muñoz, A., Arenas, C., GonzÁlez, A., LuZÓN, A., Pardo, G., Pérez, A. y Villena, J. 2002: 
«Ebro basin (northeastern Spain)». En Gibbons, W. y Moreno, T. (eds.): The geology of Spain. Geological Society. Londres, 301-309.

Pardo, G., Arenas, C., GonzÁlez, A., LuZón, A., MuÑoz, A., PÉreZ, A., PÉreZ-Rivarés, F.J., VÁZQuez, M. y VILlenA, J. 2004: «La Cuenca del Ebro». En Vera, J.A. (ed.): Geología de España. Soc. Geol. España e ITGE, 533-543. Madrid.

Peña, J.L., ChuecA, J., Julián, A. y EcheveRRÍA, M.T. 1996: «Reconstrucciones paleoambientales en el sector central de la depresión del Ebro a partir de rellenos de valle y conos aluviales». En Pérez Alberti, A. et al. (eds.): Dinámica y evolución de medios cuaternarios. Xunta de Galicia. Santiago de Compostela, 291-307.

Peña, J.L., Chueca, J., Julián, A. y EcheveRRÍA, M.T. 1998: «Los estudios geoarqueológicos en la reconstrucción del paisaje: $\mathrm{Su}$ aplicación en el valle bajo del río Huerva (Depresión del Ebro)». Arqueología Espacial, 19-20, Arqueología del paisaje, 169-183. Teruel.

PeÑa, J.L., Echeverría, M.T., Julián, A., y ChueCA, J. 2001: «Processus d'accumulation et d'incision pendant l'Antiquité Classique dans la vallée de la Huerva (Bassin de l'Ebre, Espagne)». En Vermeulen, F. y de Dapper, M. (eds.): Geoarchaeology of the Landscapes of Classical Antiquity, ed. Peeters. Leuven, 151-159.

PeÑA, J.L., EChEVERríA, M.T., PETIT-MAIRE, N. y LAFONT, R. 1993: «Cronología e interpretación de las acumulaciones holocenas de la val de la Lenas (Depresión del Ebro, Zaragoza)». Geographicalia, 30, 321-332.

PeÑA, J.L., GenÉ, V. y RUBIO, V. 2009: «El contexto geomorfológico y geoarqueológico». En Picazo, J. y Rodanés, J.M.: Los poblados del Bronce Final y Primera Edad del Hierro. Cabezo de la Cruz, La Muela, Zaragoza, Gobierno de Aragón. Zaragoza, 85-99.

Peña, J.L., Julián, A., ChueCA, J., EChEVERríA, M.T. y ÁnGELES, G. 2004: «Etapas de evolución holocena en el valle del río Huerva: Geomorfología y geoarqueología». En Peña, J.L. et al. (eds.): Geografía Física de Aragón. Aspectos generales y temáticos. Universidad de Zaragoza e Institución Fernando el Católico. Zaragoza, 289-302.<http:// age.ieg.csic.es/fisica/docs/06-memoria.htm>.

PEÑA, J.L. y LOZANO, M.V. 2004: «Las unidades del relieve aragonés». En Peña, J.L. et al. (eds.): Geografía Física de Aragón. Aspectos generales y temáticos. Universidad de Zaragoza e Ins- titución Fernando el Católico. Zaragoza, 3-14. $<$ http://age.ieg.csic.es/fisica/docs/06-memoria. htm>.

PeÑA, J.L., Rubio, V. y GonZÁleZ, J.R. 2005: «Aplicación de modelos geomorfológicos evolutivos al estudio de yacimientos arqueológicos en medios semiáridos (Depresión del Ebro, España)». X Coloquio Ibérico de Geografía. A geografia iberica no cotexto europeo. 15 p., ed. digital. Évora. <http://www.apgeo.pt/index.php?section= $134 \&$ module $=$ navigationmodule $>$.

PEÑA, J.L., SANCHO, C. y RUBIO, V. 2005: «Aportaciones desde la geomorfología y la geoarqueología al conocimiento de los paleoambientes holocenos del NE de España». Actas X Coloquio Ibérico de Geografía. A geografia iberica no cotexto europeo. 15 p. Ed. digital. Évora. <http:// www.apgeo.pt/index.php?section $=134 \&$ module $=$ navigationmodule $>$.

Pérez, A., Muñoz, A., PARdo, G., Villena, J. y ArEnAS, C. 1988: «Las unidades tectosedimentarias del Neógeno del borde ibérico de la depresión del Ebro (sector central)». En Pérez, A. et al. (eds.): Sistemas lacustres neógenos del margen ibérico de la Cuenca del Ebro. IGCP 219. Comparative lacustrine sedimentology in space and time. Guía de campo. III Reunión Grupo Español de Trabajo, 7-20.

QUIRANTES, J. 1978: Estudio sedimentológico del Terciario continental de los Monegros. Institución Fernando el Católico, 200 p. Zaragoza.

Riba, O., REguANT, S. y VillenA, J. 1983: «Ensayo de síntesis estratigráfica y evolutiva de la cuenca del Ebro». En Libro Jubilar J.M. Ríos. Geología de España, IGME. Madrid. T. 2, 131-159.

SORIANO, M.A. 1989: «Infilled valleys in the Central Ebro Basin (Spain)». Catena, 16: 357-367.

—, 1990: Geomorfología del sector centromeridional de la Depresión del Ebro. Institución Fernando el Católico, 269 p. Zaragoza.

SORIANO, M.A. y CALVO, J.M. 1987: «Características, datación y evolución de los valles de fondo plano de las inmediaciones de Zaragoza». Cuaternario y Geomorfología, 1: 283-293.

YETANO, L.M. 1977: La evolución geomorfológica del valle de la Huerva. Geographicalia, 2. Zaragoza.

ZUIDAM, R.A. VAN. 1976: Geomorphological development of the Zaragoza region, Spain. ITC, 221 p. Enschede. 


\subsection{LOS USOS DE LOS VEGETALES LEÑOSOS EN EL CABEZO DE LA CRUZ (LA MUELA, ZARAGOZA) DURANTE LA OCUPACIÓN MESOLÍTICA}

ERNESTINA BADAL GARCÍA*

\subsubsection{INTRODUCCIÓN, BIOGEOGRAFÍA Y ARQUEOLOGÍA}

El Cabezo de la Cruz (Zaragoza) es un yacimiento arqueológico de gran extensión y complejidad, tanto por la secuencia cultural como por las estructuras arquitectónicas conservadas. Esa complejidad se puede agrupar en tres grandes momentos de ocupación humana: el Mesolítico, la Edad del Bronce y la Edad del Hierro (Rodanés y Picazo 2006; Picazo y Rodanés 2008, 2009). En el presente trabajo nos centraremos en la información obtenida a partir de la madera utilizada en el Mesolítico. Efectivamente, en la zona oeste del área intervenida se documentó un campamento mesolítico cuyos niveles superiores están datados en 6244-5731 cal BC al 95,3\% de probabilidades. El hallazgo es interesante porque son muy pocos los asentamientos al aire libre que se conocen de este período y es verdaderamente una excepción que se hayan conservado carbones asociados a las estructuras de hábitat. Por tanto, el análisis del uso de los recursos leñosos por parte de sociedades cazadoras-recolectoras en hábitat al aire libre puede contribuir a conocer la vegetación natural de la zona antes de la intervención humana a gran escala que se realiza a partir de la introducción de la agricultura y la ganadería.

La antracología se encarga de la recogida, identificación botánica y conservación de los carbones recuperados en contextos arqueológicos. Dichos restos están en directa relación con las actividades humanas, así la información que proporcionan será de orden etnográfico, botánico y ecológico. Los restos bióticos constituyen una importante fuente de información sobre el patrimonio biológico y cultural. El material tratado procede de la excavación que se realizó en el yacimiento a lo largo de 2004 bajo la dirección de J. M. ${ }^{a}$ Rodanés y J. Picazo de la Universidad de Zaragoza. En el trabajo de campo se hizo un muestreo sistemático de los restos bióticos con el objetivo de conocer el entorno medioambiental

\footnotetext{
* Departamento de Prehistoria y Arqueología. Universidad de Valencia,<ernestina.badal@uv.es>.
}

del yacimiento a lo largo de la Prehistoria. Los niveles mesolíticos aportarán información sobre la flora local y, en vista de la tecnología de estas sociedades, se puede postular una imagen del paisaje natural sin impacto humano significativo.

El yacimiento se encuentra en el término de La Muela, provincia de Zaragoza, en las coordenadas UTM 30661186 - 459551 y a una altitud de 428 metros sobre el nivel del mar. Se sitúa en la ladera de un cerro que domina el curso medio del río Huerva, tributario del Ebro. Las condiciones bioclimáticas actuales son de tipo mesomediterráneo. Los valores climáticos normales tomados en el aeropuerto de Zaragoza pueden ayudar a comprender los resultados antracológicos del Cabezo de la Cruz por estar en el mismo ámbito climático. Así, la temperatura media anual es de unos $15{ }^{\circ} \mathrm{C}$. La media de la temperatura mínima diaria del mes de enero es de $2,4^{\circ} \mathrm{C}$. Como todo el valle del Ebro tiene un clima contrastado con veranos calurosos e inviernos fríos, donde el número medio anual de días con heladas es de 25 . Las precipitaciones son de tipo semiárido ya que no superan los $350 \mathrm{~mm}$ de media anual y con un periodo de sequía estival marcado (datos obtenidos en <http://www.aemet.es>).

El paisaje actual está completamente humanizado y modelado por las actividades agrícolas; hacia el oeste del yacimiento se dan cultivos de secano, esencialmente cereales y algunas zonas de eriales donde crecen matorrales bajos de tomillo con pino carrasco y enebros dispersos. Mientras que hacia el este del yacimiento, el curso constante, aunque de reducido caudal del río Huerva, favorece los cultivos de regadío y una vegetación natural de ribera con taráis, chopos, sauces y otras especies hidrófilas. Así pues, poca superficie mantiene vegetación natural y esta presenta un aspecto ralo, de carácter estépico, con albardín (Lygeum spartum), tomillo (Thymus), Artemisia, etc.

\subsubsection{MÉTOdos y MATERIALES}

La excavación arqueológica se realizó en extensión por la ladera del Cabezo y, con el fin de realizar estudios medioambientales, se plantearon, en estrecha colaboración con los directores de la excavación, estrategias de muestreo de los restos bióticos. Dentro de esos materiales se encuentran los carbones sedimentados en la estratigrafía. En la ladera sur-oeste del Cabezo se excavó un campamento del Mesolítico (Rodanés y Picazo 2006; Picazo y Rodanés 2008, 2009). 
Se trata de un fondo de cabaña de forma ovalada de unos 4,5 m de diámetro; de su interior proceden dos unidades estratigráficas (UE 1398 y UE 1351) que han proporcionado carbón disperso por el sedimento, incluso alguna pieza corresponde a troncos de buen calibre que se muestreó a mano (UE 1397) y que, después de su identificación botánica, fue datado por radiocarbono. Hacia el centro de la cabaña se identificó una estructura de combustión en cubeta que funcionó como hogar (UE 1450); alrededor de ella se excavaron tres agujeros de poste, de uno de ellos (UE 1465) se obtuvo un fragmento de tronco carbonizado. Fuera del hogar, pero del mismo nivel, se ha analizado otro fragmento de madero carbonizado (UE 1440).

La estrategia de muestreo en el yacimiento siguió el protocolo habitual:

a) Lavado de las tierras

Se tomó una muestra de unos 10 litros de sedimento por unidad estratigráfica. Las tierras procedentes de la estructura de combustión (UE 1450) y de los niveles de ocupación (UE 1398 y UE 1351) se lavaron con la cuba de flotación que tiene un tamiz interior de malla fina sobre la cual se sitúa un tejido en el que se deposita el sedimento; el flujo de agua y aire entra por debajo del tamiz, cuando la cuba se llena de agua, desborda por un aliviadero donde se sitúa otro tamiz fino en el cual se colocó otro trozo del mismo tejido para que quedaran atrapados los carbones y semillas que flotaban. Como la mayoría no flotaban, también se guardaron los restos que quedaron en los tejidos tanto el de dentro como el de fuera de la cuba. Una vez lavada toda la tierra de una Unidad Estratigráfica, los restos se ponían a secar dentro de las telas con su etiqueta de procedencia.

\section{b) Manual}

En el nivel de ocupación se distinguieron algunos troncos esparcidos por el sedimento y relativamente largos que fueron muestreados a mano (UE 1397, UE 1440). En los agujeros de poste se recogió a mano si había un gran fragmento de carbón y además se lavó la tierra (UE 1465).

Después del lavado, las tierras se dejaron secar. Una vez secas las muestras se procesaron en el laboratorio del departamento de Prehistoria y Arqueología de la Universidad de Valencia. El conjunto es armónico porque corresponde a una unidad de habitación mesolítica. En ella se ha distinguido: a) El hogar (UE 1450) contenía 134 fragmentos de carbón concentrados en la zona rubefactada de la cubeta donde se realizó la hoguera en el centro de la cabaña. Este carbón refleja una acción puntual y concreta, por tanto, informa de la última leña que se echó al fuego y que, sin duda, refleja la acción previa de recogida de la leña en el territorio circundante y acarreo de la misma al asentamiento.

b) Un poste de construcción (UE 1465) que puede reflejar la madera que formaba parte de las estructuras de la cabaña (fig. 1).

c) Carbón disperso por el nivel de ocupación del que se recogieron dos unidades estratigráficas (UE 1398; UE 1351). Es donde más fragmentos de carbón había, pues se ha analizado un total de 465 carbones (fig. 1). Del mismo nivel se individualizaron dos maderos (UE 1397 y UE 1440). Este material refleja una acción más imprecisa en el tiempo. Puede ser más largo el periodo de tiempo que esos residuos tardan en acumularse y, por tanto, reflejar varias recogidas de leña, además de varios vaciados y limpiezas de los hogares. Por otro lado, los dos troncos, por su disposición y tamaño, pueden ser parte de los postes estructurales de la cabaña que en su fase final se incendiara.

El protocolo de análisis anatómico de todo el material ha seguido varias etapas:

A) Identificación botánica del tejido vegetal; para ello se realizó la observación de los tres planos anatómicos de la madera en un microscopio óptico de luz reflejada con campo claro - campo oscuro de Nikon modelo Optiphot-100. En ese proceso, la preparación de las muestras es puramente mecánica, es decir, el material se parte con las manos sin utilizar ningún tipo de tratamiento químico, lo cual permite con posterioridad utilizar técnicas de radiocarbono sobre el mismo resto orgánico (Vernet et al. 1979; Bernabéu et al. 1999; Badal 2009). Los caracteres anatómicos se contrastaron con material fresco carbonizado (fig. 4) y con la bibliografía especializada en anatomía vegetal (Jacquiot 1955; Jacquiot et al. 1973; Schweingruber 1990). Este análisis se ha realizado en el laboratorio del departamento de Prehistoria y Arqueología de la Universidad de Valencia.

El método empleado no contamina los carbones, por tanto, después de la identificación botánica se seleccionó el material necesario para 


\begin{tabular}{|c|c|c|c|c|c|c|c|c|c|}
\hline CABEZO DE LA CRUZ & \multirow{2}{*}{\multicolumn{2}{|c|}{$\begin{array}{c}\text { Hogar } \\
\text { UE } 1450 \\
\end{array}$}} & \multicolumn{4}{|c|}{ Carbón disperso } & Poste & Poste & $\begin{array}{l}\text { Agujero } \\
\text { de poste }\end{array}$ \\
\hline EPIPALEOLÍTICO & & & \multicolumn{2}{|c|}{ UE 1398} & \multicolumn{2}{|c|}{ UE 1351} & UE 1397 & UE 1440 & UE 1465 \\
\hline Radiocarbono BP & \multicolumn{2}{|c|}{$6970 \pm 40$} & & & \multicolumn{2}{|c|}{$7130 \pm 130$} & $7150 \pm 70$ & & \\
\hline Taxa / Frecuencias & $N$ & $\%$ & $N$ & $\%$ & $N$ & $\%$ & $N$ & $N$ & $N$ \\
\hline Pinus halepensis & 75 & 55,97 & 184 & 69,43 & 178 & 89 & 1 & 1 & 1 \\
\hline Pinus sp. & 12 & 8,96 & 28 & 10,57 & 14 & 7 & & & \\
\hline Corteza de pino & 10 & 7,46 & 22 & 8,30 & & & & & \\
\hline Bractea de pina & & & 1 & 0,38 & & & & & \\
\hline Juniperus sp. & 7 & 5,22 & 6 & 2,26 & 2 & 1 & & & \\
\hline Conifera & 5 & 3,73 & 11 & 4,15 & 6 & 3 & & & \\
\hline Monocotiledónea & 1 & 0,75 & 1 & 0,38 & & & & & \\
\hline Labietae cf. Lavandula & & & 9 & 0,75 & & & & & \\
\hline Prunus sp. & 1 & 0,75 & 1 & 0,38 & & & & & \\
\hline Quercus sp. & 2 & 1,49 & & & & & & & \\
\hline Quercus sp. Caducifolio & 1 & 0,75 & & & & & & & \\
\hline Quercus sp.Perennifolio & 2 & 1,49 & & & & & & & \\
\hline Rhamnus o Phillyrea & 1 & 0,75 & & & & & & & \\
\hline Semilla indeterminada & 11 & 8,21 & 8 & 3,02 & & & & & \\
\hline Hueso & 1 & 0,75 & 1 & 0,38 & & & & & \\
\hline Indeterminada 1 & 4 & 2,99 & & & & & & & \\
\hline Indeterminada 2 & 1 & 0,75 & & & & & & & \\
\hline Total carbón & 134 & 100 & 265 & 100 & 200 & 100 & 1 & 1 & 1 \\
\hline
\end{tabular}

Figura 1. Resultados antracológicos del Mesolítico en el Cabezo de la Cruz.

realizar las dataciones por el método del radiocarbono, de donde se han obtenido las dataciones publicadas (Rodanés y Picazo 2006; Picazo y Rodanés 2009).

B) Toma de fotografías y observación de microorganismos: se ha realizado en el microscopio electrónico de barrido Hitachi S-4100 de Emisión de Campo por medio del programa de captación de imagen EMIP 3.0 (Electron Microscope Image Processing) en el laboratorio de Microscopia Electrónica del Servicio Central de Soporte a la Investigación Experimental (SCSIE) de la Universidad de Valencia. Para la observación en el microscopio electrónico de barrido (MEB), el material se fijó con cinta de carbono en el porta-objetos, se metalizó con oro para facilitar la conductividad y se sometió al vacío. El material así tratado no puede ser datado por radiocarbono.

C) El estado de conservación de los carbones era correcto y se han podido identificar todos los restos. No obstante, se han detectado microorganismos que reducen y descomponen la materia orgánica y son los causantes de la pérdida de material biótico en los procesos postdeposicionales de los yacimientos. Animales, bacterias y hongos se entremezclan y actúan en los sedimentos consumiendo los restos orgánicos, en este caso el carbón prehistórico. No obstante, los carbones mesolíticos del Cabezo de la Cruz estaban muy limpios y solamente se han observado cadenas de bacterias e hifas (fig. 5).

\subsubsection{CARBÓN Y RADIOCARBONO}

El carbón es un material arqueológico que contiene múltiple información: ecológica, etnográfica, taxonómica, cronológica, etc. Pero para obtener alguna de esas informaciones el método empleado es destructivo (p. ej., el radiocarbono), por tanto, la secuencia de análisis debe ser concertada de modo que no se destruya ningún tipo de información. Desde los años sesenta, la arqueología y la paleoecología se apoyan en las fechas radiocarbono para situar en la escala temporal los conjuntos arqueológicos, los cambios climáticos, la aparición o desaparición de ciertas especies vegetales, etc. Como hemos visto, en el proceso estándar de análisis del carbón, este no recibe ningún tratamiento químico, por tanto, sobre ese mismo fragmento se puede obtener a posteriori dataciones radiométricas, sin destruir la información botánica y antropológica (Vernet et al. 1979).

La secuencia de análisis que se ha seguido en el Cabezo de la Cruz ha sido: primero la identificación botánica y, después, se enviaron los fragmentos de carbón seleccionados al laboratorio de radiocarbono, donde se destruye definitivamente 
el material (fig. 2). Esta secuencia de análisis tiene el interés particular de saber qué género o especie vegetal se fecha, por tanto, se puede seguir su historia, se pueden refutar o avalar hipótesis sobre refugios en el último ciclo glacial, fácilmente postulados por los palinólogos pero de difícil confirmación solo con el polen. Cuando se data el carbón de un taxón vegetal (p. ej., un Pinus halepensis) se obtiene la única fecha directa, es decir, dentro del conjunto de materiales recuperados en una Unidad Estratigráfica, el único resto fechado es el carbón, en este caso el Pinus halepensis. La fecha obtenida se extrapola al conjunto de los materiales recuperados en la Unidad Estratigráfica, pero pueden ser o no ser contemporáneos del carbón datado (Badal 2009). Si no se obtiene la fecha esperada se habla de «intrusión», «contaminación», etc. En realidad, lo único verdadero es que se ha datado un carbón de Pinus halepensis y ha dado un resultado cronológico que nos ayuda a seguir la historia de las plantas.

En el material mesolítico del Cabezo de la Cruz, se seleccionó carbón de Pinus halepensis (pino carrasco) para ser datado por radiocarbono. Esta selección intencionada tiene dos razones: en primer lugar, porque queremos saber el origen del pino carrasco y su área de distribución natural previa a la llegada del Neolítico. Segundo, porque en los estudios fitosociológicos siempre se le considera como vegetación secundaria y dentro de las fases regresivas del bosque mediterráneo como consecuencia de las actividades humanas en los territorios. Así que nunca se le trata con la misma categoría que a los otros pinos mediterráneos. Por todo ello, consideramos que este pino merece una atención especial para clarificar su historia, en ese sentido el material del Cabezo de la Cruz se constituye en un buen indicador y merecía la pena tener dataciones de radiocarbono directas de pino carrasco (Pinus halepensis). Para la datación se seleccionaron dos fragmentos de carbón grandes. Uno procedente del agujero de poste (UE 1465) que ha dado la fecha GrN-29134: 7130 \pm 130 . El otro estaba disperso por el nivel de ocupación (UE 1351) y sus resultados son: GrN-29135: $7150 \pm 70$ BP (fig. 2). Resalta la coherencia entre ambas dataciones que nos ayudan a reconstruir la historia de este pino y, además, están en concordancia con la cultura material documentada (Picazo y Rodanés 2008, 2009).

\subsubsection{FLORA}

El término «flora» en este contexto se refiere a la lista o conjunto de plantas leñosas identificadas en los carbones del Cabezo de la Cruz, que son el producto directo de los usos que hicieron los habitantes de los vegetales leñosos. Por tanto, reflejan la flora local que vivía en el territorio de captación de recursos de los pobladores mesolíticos. En sociedades cazadoras-recolectoras los criterios de recogida de leña para el fuego son oportunistas, prevaleciendo la ley esfuerzo-rendimiento, por

\begin{tabular}{|c|c|c|c|c|c|c|}
\hline Especie & Referencia & Años en $B P$ & Nivel & Yacimiento & $A M S$ & Referencia \\
\hline Pinus halepensis & AA-59519 & $7526 \pm 44$ & UE 3151 & La Falaguera (Alcoi) & AMS & García y Aura 2006 \\
\hline Pinus halepensis & Beta-171909 & $7280 \pm 40$ & UE 3201 & La Falaguera (Alcoi) & AMS & $\begin{array}{l}\text { García y Molina } \\
2005\end{array}$ \\
\hline Pinus halepensis & GrN-29135 & $7150 \pm 70$ & UE 1397 & $\begin{array}{l}\text { Cabezo de la Cruz } \\
\text { (La Muela) }\end{array}$ & AMS & $\begin{array}{l}\text { Picazo y Rodanés } \\
2008\end{array}$ \\
\hline Pinus halepensis & GrN-29134 & $7130 \pm 130$ & UE 1351 & $\begin{array}{l}\text { Cabezo de la Cruz } \\
\text { (La Muela) }\end{array}$ & AMS & $\begin{array}{l}\text { Picazo y Rodanés } \\
2008\end{array}$ \\
\hline Pinus halepensis & Beta-90884 & $5660 \pm 80$ & Fase II & $\begin{array}{l}\text { Cerro de la Virtud } \\
\text { (Cuevas de Almazora) }\end{array}$ & AMS & $\begin{array}{l}\text { Ruiz, Taboada } \\
\text { y Montero } 1999\end{array}$ \\
\hline Pinus halepensis & Beta-135665 & $4.480 \pm 40$ & $\begin{array}{l}\text { MF-66158 } \\
\text { Derrumbe }\end{array}$ & $\begin{array}{l}\text { Los Castillejos } \\
\text { (Montefrío) }\end{array}$ & AMS & $\begin{array}{l}\text { Cámara, Molina } \\
\text { y Afonso } 2005\end{array}$ \\
\hline Pinus halepensis & Beta-135668 & $3640 \pm 120$ & \multirow{2}{*}{$\begin{array}{l}\text { MF-613319 } \\
\text { Derrumbe } \\
\text { El mismo } \\
\text { ejemplar }\end{array}$} & \multirow{2}{*}{$\begin{array}{l}\text { Los Castillejos } \\
\text { (Montefrío) }\end{array}$} & Radio/Conv & \multirow{2}{*}{$\begin{array}{l}\text { Cámara, Molina } \\
\text { y Afonso } 2005\end{array}$} \\
\hline Pinus halepensis & Beta-145303 & $3960 \pm 50$ & & & AMS & \\
\hline Pinus halepensis & GrN-29136 & $2690 \pm 20$ & UE 1459 & $\begin{array}{l}\text { Cabezo de la Cruz } \\
\text { (La Muela) }\end{array}$ & Radio/Conv & $\begin{array}{l}\text { Picazo y Rodanés } \\
2009\end{array}$ \\
\hline Pinus halepensis & GrN-29140 & $2610 \pm 20$ & UE 1621 & $\begin{array}{l}\text { Cabezo de la Cruz } \\
\text { (La Muela) }\end{array}$ & Radio/Conv & $\begin{array}{l}\text { Picazo y Rodanés } \\
2009\end{array}$ \\
\hline
\end{tabular}

Figura 2. Dataciones AMS realizadas directamente sobre carbones de Pinus halepensis de la prehistoria peninsular. 

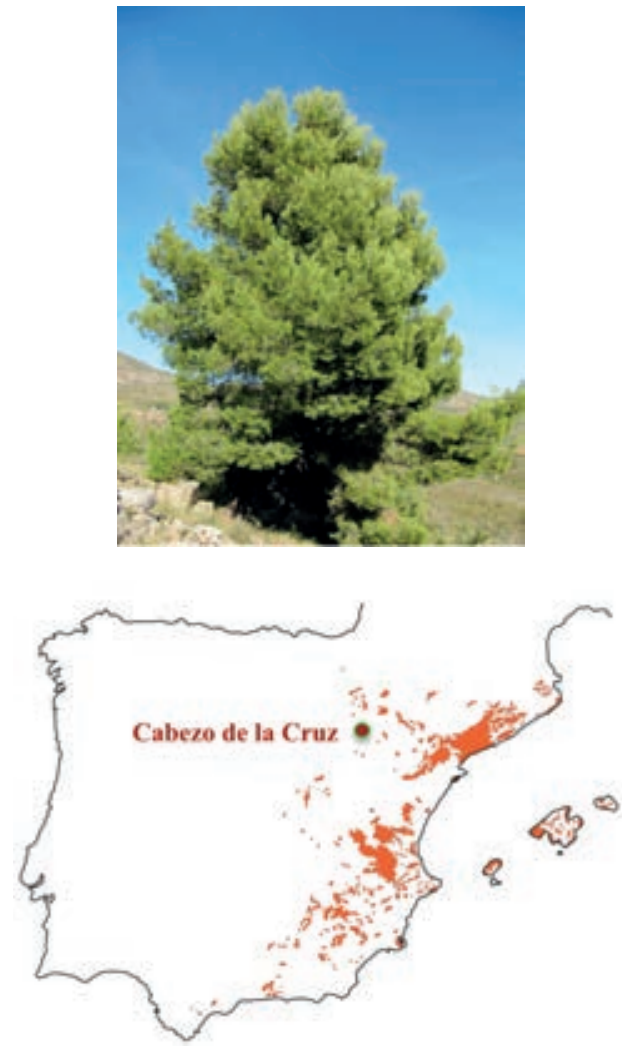

Figura 3. Mapa de distribución anual de Pinus halepensis (a partir de Costa et al. 2001). Distribución biogeográfica del Pinus halepensis y del Pinus nigra en relación con la altitud y la latitud. Se indica la situación del Cabezo de la Cruz.

tanto, una selección mínima y no orientada sobre alguna especie en concreto. Por los análisis antracológicos realizados tanto en yacimientos arqueológicos como en etnográficos, se observa que lo más quemado corresponde a la especie o especies más abundantes en el entorno inmediato al asentamiento y que dependen directamente de la ecología de cada región (Badal 1992; Chabal et al. 1999; Ntinou et al. 1999; Ntinou 2002; Carrión 2005). En base a este principio se pueden hacer inferencias paleoecológicas.

En la figura 1, se puede observar la lista de plantas identificadas así como las frecuencias alcanzadas en cada una de las unidades estratigráficas. Llegar a la identificación específica es interesante porque las especies se distribuyen en los territorios buscando satisfacer sus exigencias ecológicas (temperatura - humedad - suelo). A menudo, cuando cambian esas condiciones en función de la altitud, la latitud, cambio climático, etc., las especies vegetales entran en competencia entre ellas y unas son sustituidas por otras; por tanto, conocer las especies ayuda a reconstruir las
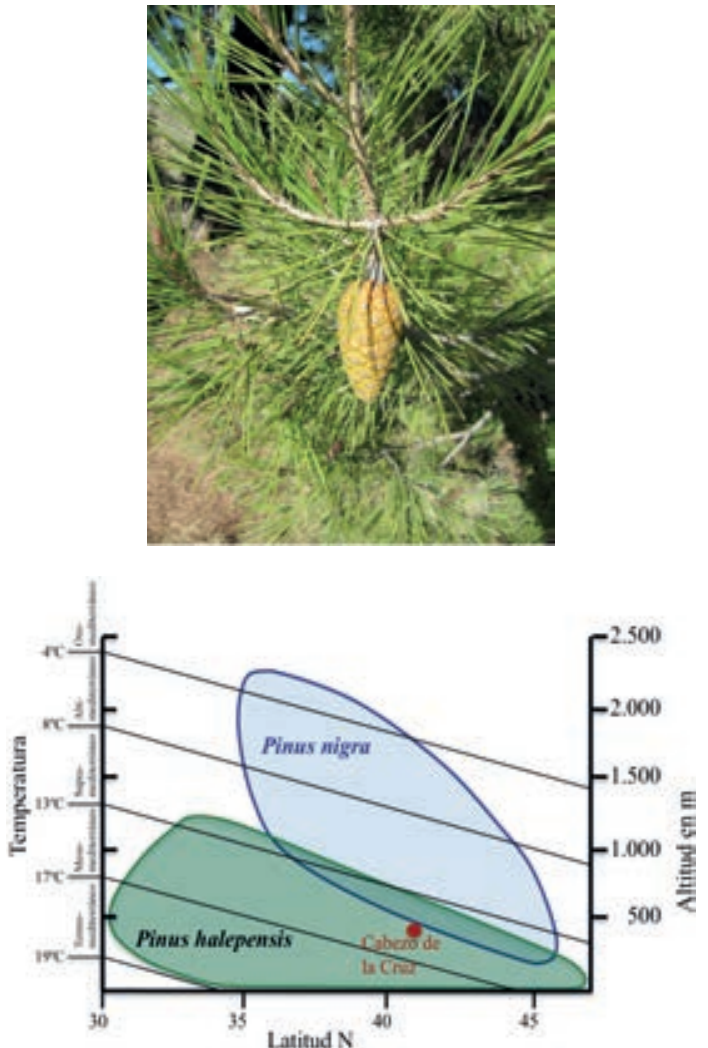

condiciones ambientales de una zona. En los carbones, con la anatomía de la madera no siempre se puede llegar a ese rango de identificación y es frecuente quedarnos en el de género, que ofrece menores precisiones ecológicas. En los carbones mesolíticos del Cabezo de la Cruz solo hemos podido identificar con seguridad una especie: Pinus halepensis (pino carrasco), por las argumentaciones realizadas en el apartado anterior nos vamos a detener especialmente en este pino.

\section{Pinus halepensis - pino carrasco}

El pino carrasco tiene la copa irregular y lobulada, con ramificación difusa desde pequeño. Es un pino de tamaño mediano y con corteza grisácea en los individuos añejos. Las acículas son pequeñas, delgadas, flexibles, de unos $10 \mathrm{~cm}$ de largo y color verde amarillento. Las piñas son alargadas, pedunculadas y revueltas, con escamas planas. Perduran en el árbol varios años después de la maduración (fig. 3).

El pino carrasco es circunmediterráneo formando una banda cercana a la costa. En la Penín- 
sula Ibérica está ampliamente distribuido por el este, penetrando en el valle del Ebro, zonas de Castilla y La Mancha (fig. 3). Tiene una tolerancia térmica comprendida entre los 12 y los $19{ }^{\circ} \mathrm{C}$ de temperatura media anual, por tanto, ocupa los pisos bioclimáticos termomediterráneo y mesomediterráneo. Un factor limitante es la temperatura mínima del mes más frío que no puede ser inferior a $-3{ }^{\circ} \mathrm{C}$ (Gil et al. 1996); además no soporta una temperatura inferior a $-5{ }^{\circ} \mathrm{C}$ durante varios días seguidos (Jacamon 1979) y tampoco las heladas tardías porque empieza muy pronto su crecimiento estacional. En la Península Ibérica, este pino encuentra las mejores condiciones para su desarrollo por debajo de los 800 metros de altitud (fig. 3). Es una especie frugal bien adaptada a los suelos pobres. El pino carrasco es termófilo, xerófilo y calcícola (Gil et al. 1996). El rasgo más genuino del pino carrasco es su resistencia a la sequía, «es frecuente que aparezca en áreas donde el período seco dura, por lo general, de 1 a 5 meses. Los máximos valores de sequía en su área se dan en zonas del valle del Ebro y del sureste peninsular» (Gil et al. 1996, 20). En cuanto a las precipitaciones, el límite inferior para desarrollarse está en $250 \mathrm{~mm}$ de media anual. Entre 250-300 mm, se sitúan las zonas más áridas del área del carrasco (valle central del Ebro, sureste peninsular). La mejores masas de carrasco se dan donde hay una lluvia media anual entre 350 y $700 \mathrm{~mm}$, en la actualidad en Cataluña y Cazorla (Gil et al. 1996). Los fitosociólogos lo interpretan siempre como etapas de sustitución y degradación de los bosques de carrascas, alcornoques y otras frondosas (Bellot 1978; Peinado y Rivas-Martínez 1987). Sin embargo, cada vez son más las voces que proclaman el protagonismo de este pino en las formaciones vegetales de la Península Ibérica (Gil et al. 1996; Gil 2008) y los macrorrestos arqueobotánicos van precisando, paulatinamente, su cronología y distribución (Ros 1985, 1992; RodríguezAriza 1992a y 1992b; Badal et al. 1994; Allué 2002; Badal 2009).

Anatomía de la madera

El pino carrasco por su peculiar anatomía es fácil de distinguir del resto de las especies de pinos. Presenta una madera homogénea con canales secretores de resina verticales distribuidos por todo el anillo de crecimiento anual, visibles en el plano transversal de la madera. El diámetro de los canales verticales es de 80 a $120 \mu \mathrm{m}$. El límite del anillo anual de crecimiento está bien marcado (fig. 4). El crecimiento anual depende de las condiciones estacionales y se pueden observar años de mayor o menor crecimiento tanto en los carbones mesolíticos del Cabezo de la Cruz como en los actuales. En los carbones mesolíticos, cuando ha sido posible, se han contado los anillos anuales de crecimiento conservados. Había desde trozos con cinco anillos hasta algunos de diecisiete. Esto quiere decir que algunas ramas o troncos tenían un mínimo de diecisiete años, aunque la mayoría tenía entorno a 10 años conservados pero puede que tuvieran más edad puesto que el carbón que se conserva es la parte interna del tronco, por lo tanto, se han consumido anillos de crecimiento anual en el proceso de combustión. En el plano longitudinal tangencial, se aprecian los canales secretores horizontales alojados en los radios leñosos (fig. 4); estos son heterogéneos, es decir, tienen células traqueidas horizontales en los extremos.

Lo más genuino de esta especie es el número y la distribución de las punteaduras pinoides en los campos de cruce observados en el plano longitudinal radial (Jacquiot 1955; Schweingruber 1990). En cada campo de cruce tiene de una a cuatro punteaduras pinoides pequeñas (fig. 4). Las traqueidas horizontales en los extremos de los radios tienen paredes lisas o poco dentadas.

El conjunto de los elementos anatómicos observados en los tres planos de la madera permite identificar con seguridad hasta el rango de especie: Pinus halepensis. Conocer la especie ayuda en la interpretación paleoecológica ya que nos basamos en sus necesidades actuales para interpretar las condiciones climáticas del pasado.

Juniperus sp. - enebro, cade, sabina, etc.

Se ha encontrado carbón de Juniperus sp en el hogar y en los niveles de la cabaña mesolítica en poca cantidad. Con la anatomía de la madera, el género se identifica sin dificultad pero las especies tienen una anatomía demasiado parecida entre ellas como para identificarlas (Schweingruber 1990). La madera de Juniperus es homóxila compuesta de traqueidas verticales y radios leñosos horizontales. El límite anual de crecimiento está bien marcado aunque este género genera falsos anillos de crecimiento, visibles en el plano transversal de la madera. Según algunos autores, las especies de Juniperus se pueden identificar contando el alto en células de los radios leñosos en el plano longitudinal tangencial. Sin embargo, en los carbones del Cabezo de la Cruz no se ha identificado la especie porque los fragmentos eran pequeños. 

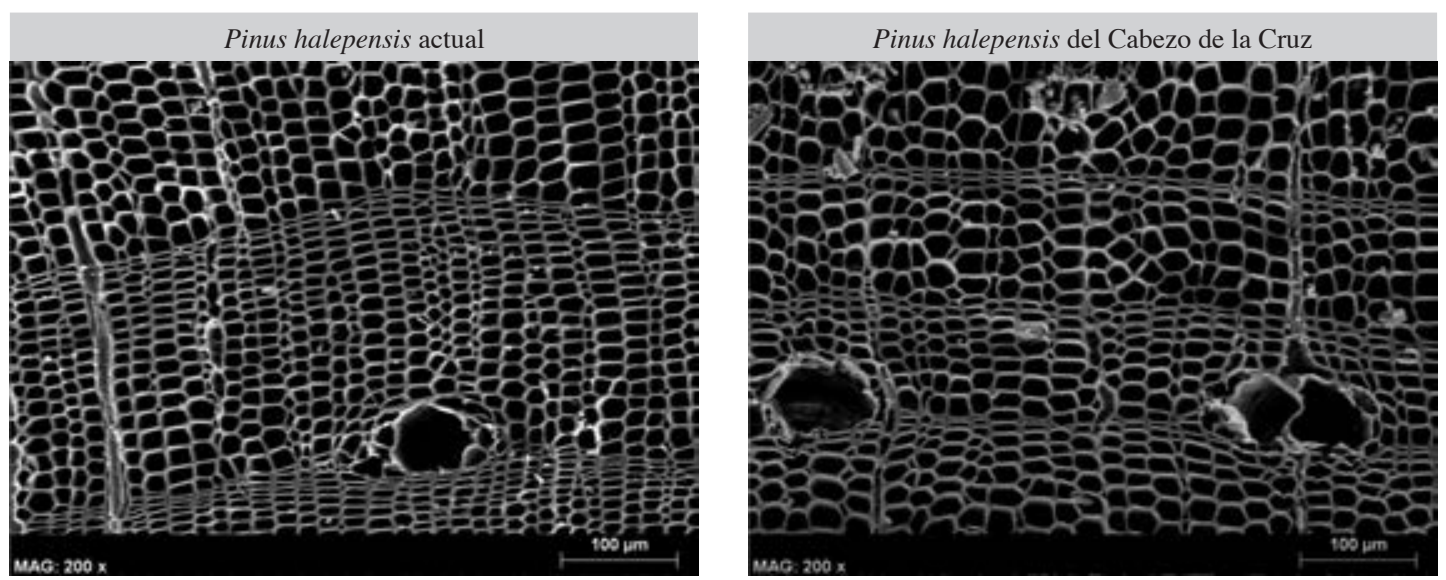

Plano transversal con canales secretores verticales en la madera inicial.
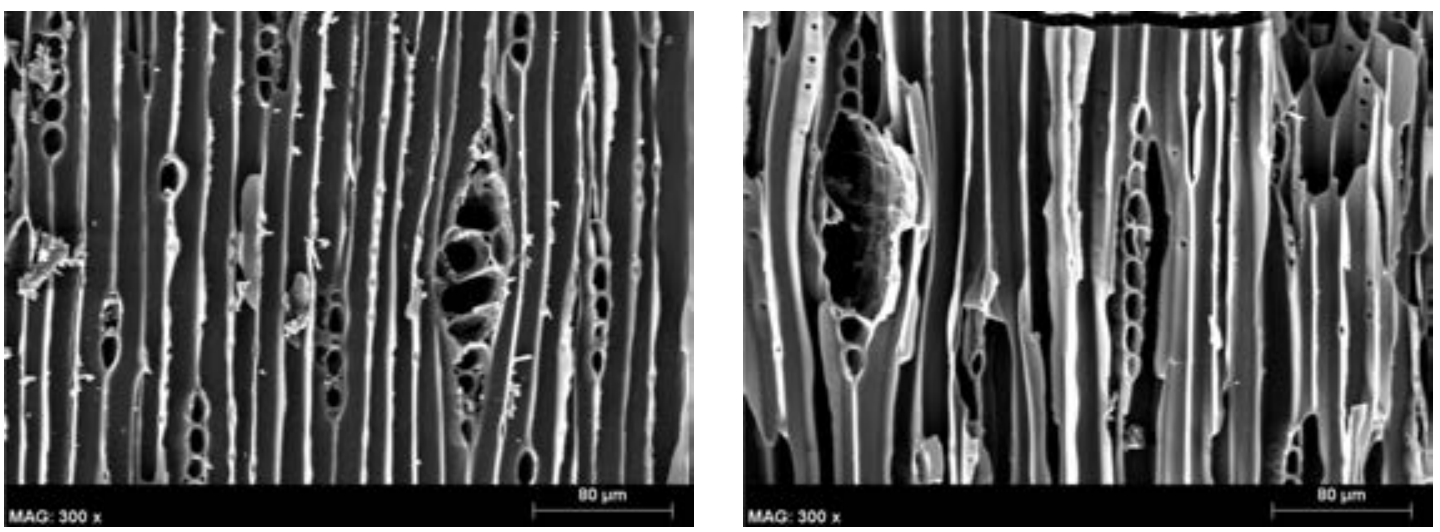

Plano longitudinal radial con canales secretores horizontales.
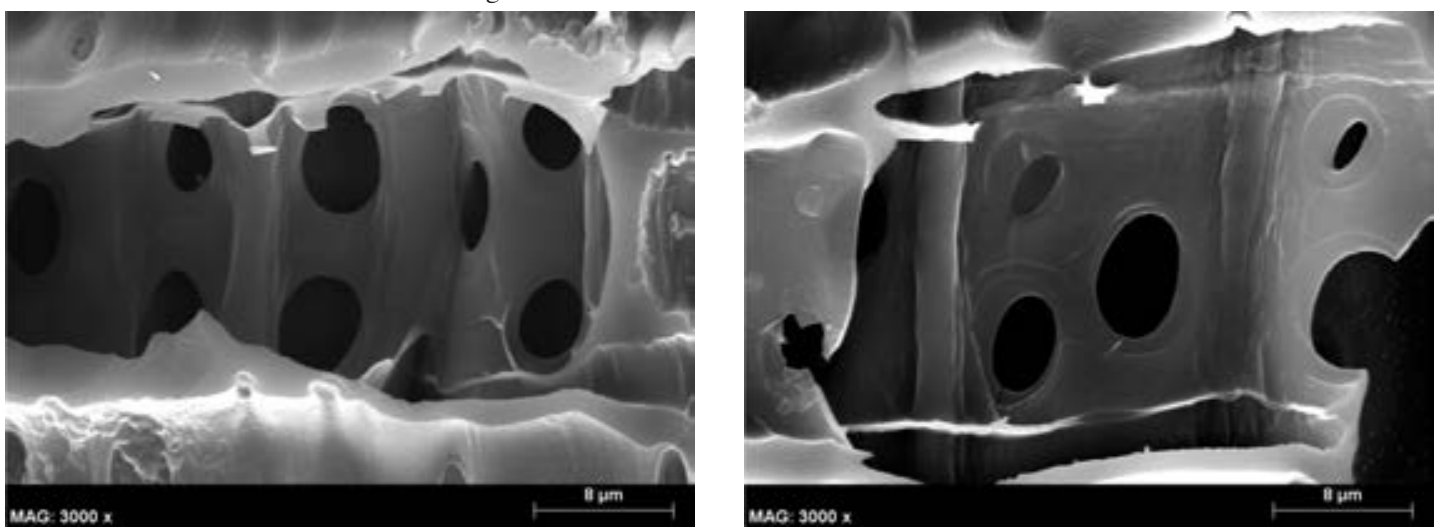

Plano longitudinal radial con dos o tres punteaduras pinoides por campo de cruce.

Figura 4. Anatomía de la madera de Pinus halepensis (pino carrasco). Columna de la izquierda pino carrasco actual. Columna de la derecha carbón prehistórico del Cabezo de la Cruz.

En el plano longitudinal radial se observaron claramente de dos a cuatro punteaduras cupresoides por campo de cruce.

Es difícil precisar la morfología y la ecología puesto que no hemos identificado la especie en los carbones analizados. Así que los Juniperus son árboles o arbustos perennifolios cuya talla y porte varía en función de la especie, desde rastreros o achaparrados hasta árboles de considerable altura. Igualmente hay especies monoicas y dioicas. Algunas especies tienen las hojas aciculares (p. ej., Juniperus oxicedrus) y otras escamiformes (p. ej., Juniperus thurifera). Conos floríferos con disposición axilar o terminal, los masculinos 
amarillos y elipsoidales o globosos y los femeninos muy poco vistosos. Ante la diversidad de especies de Juniperus es inviable dar mayores precisiones ecológicas, pero visto que en el Cabezo de la Cruz va acompañando al pino carrasco pensamos debe tratarse de Juniperus oxicedrus o Juniperus phoenicea, por ser un elemento característico del cortejo arbustivo de los pinares de carrasco, pero esto es solo una hipótesis.
Quercus sp. caducifolio y perennifolio

Con la anatomía de la madera se distinguen perfectamente los Quercus que son caducifolios (Quercus faginea, Q. pyrenaica, Q. pubencens, etc.) de los perennifolios ( $Q$. ilex, $Q$. coccifera, etc.), pero dentro de cada grupo no se distinguen las especies (Jacquiot et al. 1973). Por ello, en el Cabezo de la Cruz hemos identificado 2 carbones de Quercus sp. perennifolios que pueden tratarse

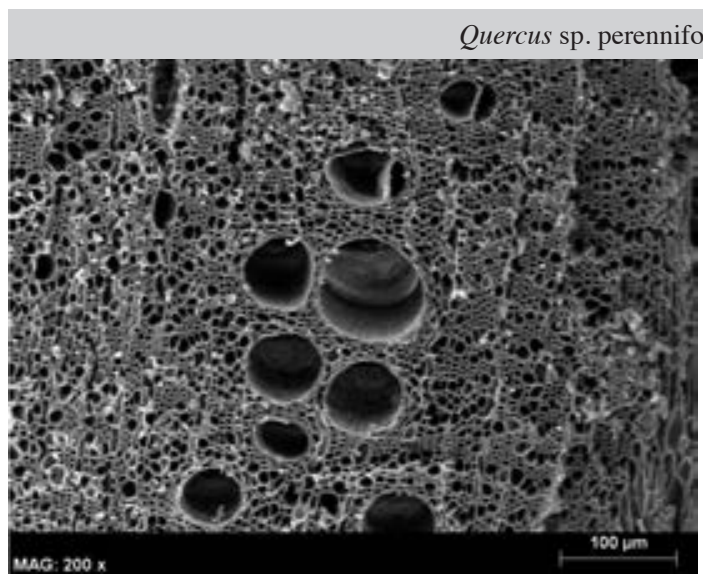

Plano transversal con vasos conductores.

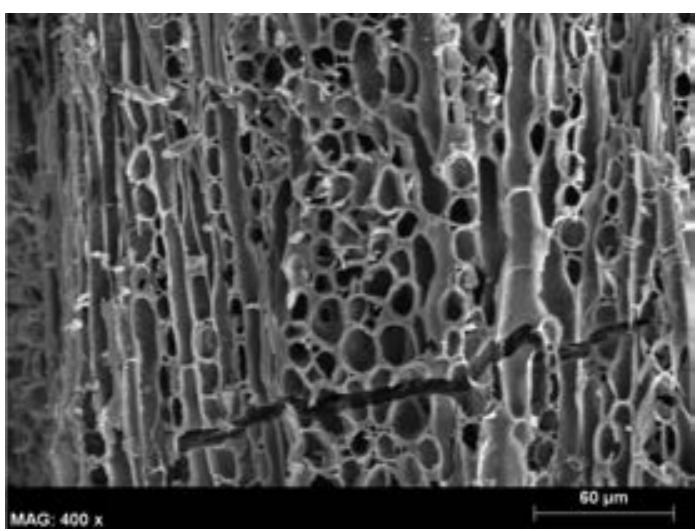

Plano longitudinal tangencial.

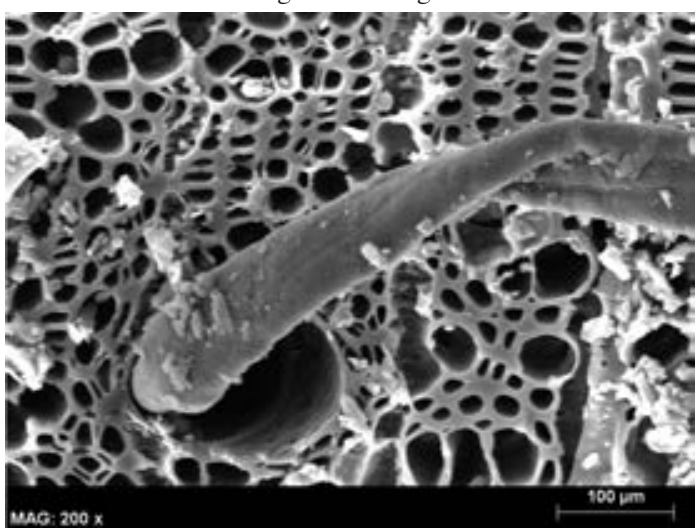

Vaso conductor atravesado por una hifa.

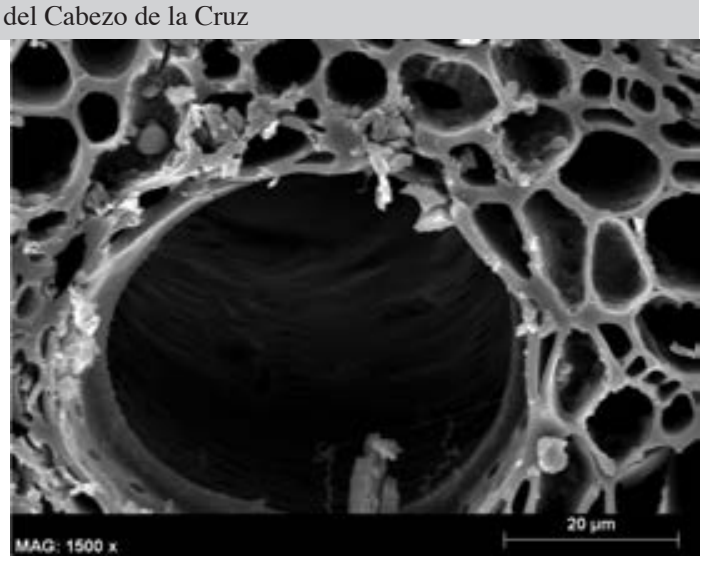

Detalle interior de un vaso conductor.

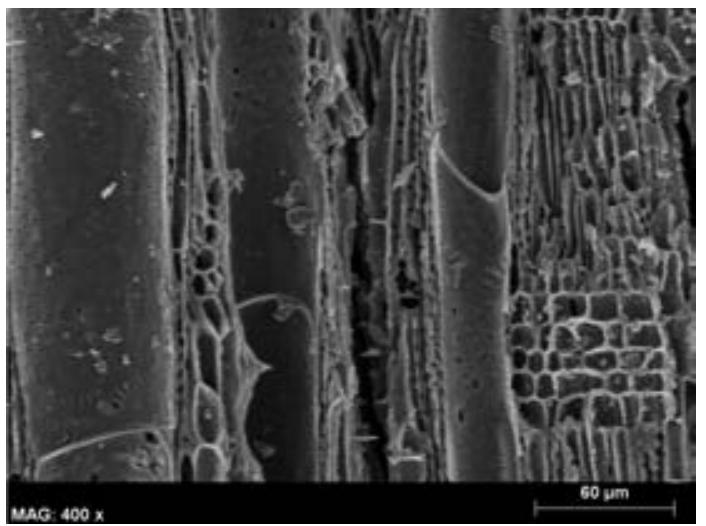

Plano longitudinal radial.

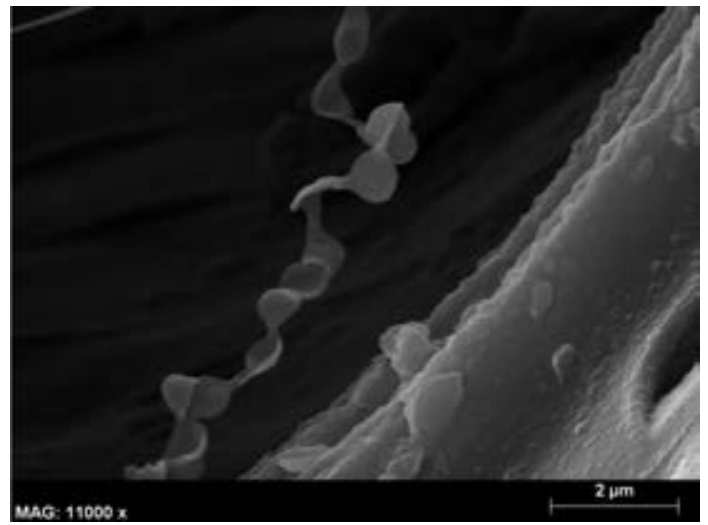

Microorganismos en interior de un vaso.

Figura 5. Anatomía de la madera de Quercus sp. perennifolio. 
de carrasca, coscoja o ambas (fig. 5). Un carbón ha sido catalogado como Quercus sp. caducifolio sin poder precisar la especie.

Todos los Quercus tienen madera heteróxila con células especializadas formando tejidos. El parénquima vertical es abundante, se presenta formando líneas tangenciales y asociado a los vasos. La gran diferencia entre los caducifolios y los perennifolios se encuentra en el plano transversal de la madera. En los Quercus sp. perennifolios los vasos conductores están repartidos de forma homogénea por toda la madera y presentan una ordenación radial (fig. 5). El diámetro de los vasos es de unos $150 \mu \mathrm{m}$ en el leño temprano, decreciendo hacia el leño tardío. El límite anual de crecimiento no está muy marcado. Por el contrario, en los Quercus sp. caducifolios los vasos conductores forman un anillo en el leño temprano, a partir del cual se distribuyen con ordenación radial. El diámetro de los vasos en el leño temprano es grande y supera fácilmente las $150 \mu \mathrm{m}$. Siendo muy pequeño al final de la estación de crecimiento. El límite anual de crecimiento es muy visible.

En el plano longitudinal tangencial y radial las diferencias anatómicas entre los Quercus perennifolio y los caducifolios no son apreciables. En ambos casos se observan radios leñosos homogéneos, formados por células de parénquima (fig. 5). De ancho pueden ser unicelulares con más de 10 células de alto o pluricelulares y, en este caso, pueden medir varios milímetros de altura. Los vasos presentan perforaciones simples entre sus elementos y punteaduras finas en sus paredes. Los Quercus perennifolios pueden vivir desde el piso bioclimático termomediterráneo hasta el supramediterráneo. No obstante, la encina o carrasca parece alcanzar su óptimo ecológico en el mesomediterráneo. La coscoja prefiere el termomediterráneo y en el mesomediterráneo se refugia en las zonas más térmicas. La carrasca es mucho más exigente en humedad que la coscoja, además sus bellotas son comestibles. El alcornoque tiene un condicionante edáfico importante y únicamente prospera en suelos ácidos o descarbonatados.

Los Quercus caducifolios son más exigentes en humedad que los perennifolios. Soportan bien las condiciones continentales de inviernos fríos y veranos secos, pero siempre están en zonas húme- das o subhúmedas, es decir, necesitan un mínimo de lluvia anual superior a los $600 \mathrm{~mm}$.

\section{Monocotiledónea}

Dos carbones uno del hogar y otro de la UE 1398 correspondían a una planta monocotiledónea. Las monocotiledóneas tienen una estructura anatómica peculiar, muy similar entre familias, géneros y especies, de tal modo que normalmente la identificación de los carbones queda en el rango de monocotiledónea. Esta imprecisión impide dar información ecológica detallada. Dentro de las monocotiledóneas se encuentra un amplio abanico de especies desde las xéricas como el albardín (Lygeum spartum) hasta las hidrófilas como enea (Typha). E incluso ambas se podrían dar en los alrededores del Cabezo de la Cruz.

\section{Labiatae}

Esta familia presenta una anatomía bastante homogénea, por tanto, no hay buenos criterios anatómicos para llegar a individualizar los géneros y las especies. Dos carbones hallados en la UE 1351 podrían ser de Lavadula porque tiene una madera semiporosa con los vasos agrupados formando flamas con ordenación radial. El diámetro de los vasos conductores es pequeño, de unos 20 $\mu \mathrm{m}$. En la pared de los vasos se distinguen engrosamientos helicoidales finos. Los radios leñosos son uniseries y heterogéneos.

La familia de las labiadas alberga muchos géneros y especies como el romero, espliego, tomillo, etc. Como la identificación quedó en el rango de familia no podemos hacer una valoración ecológica.

\section{Prunus sp.}

El género Prunus comprende varias especies como el endrino (Prunus spinosa) el cerezo de Santa Lucía (Prunus mahaleb), el almendro (Prunus amygdalus), etc. Por la anatomía de la madera se identifica el género sin ambigüedad, pero no siempre se pueden discriminar las especies.

Un carbón del hogar y otro del nivel de la cabaña mesolítica se correspondían con los caracteres anatómicos de Prunus. En el plano transversal la disposición de los vasos conductores era difusa o un poco marcando una zona semiporosa. Los vasos estaban aislados o formando grupos con ordenación radial. En los planos longitudinales se apreciaban finos engrosamientos helicoidales en 
las paredes de los vasos y perforación simple entre los elementos (Jacquiot et al. 1973; Schweingruber 1990). En el plano longitudinal tangencial se distinguieron dos tipos de radios leñosos. Los de una célula de ancho y hasta cinco de alto y los multicelulares que podían tener hasta seis células de ancho por más de veinte de alto. En ambos casos eran heterogéneos.

Los Prunus son actualmente frecuentes en formaciones vegetales del piso mesomediterráneo y supramediterráneo. Todos los Prunus son de hoja caduca y viven en los márgenes de los bosques, sobre suelos frescos. Son resistentes a las heladas de invierno pero sensibles a las tardías porque florecen relativamente pronto y pueden ser dañadas sus flores y frutos.

\section{Rhamnus - Phillyrea}

A pesar de ser familias y géneros diferentes el Rhamnus (ramnácea) y la Phillyrea (oleácea), tienen una anatomía similar que rara vez se puede individualizar uno de otro. Un carbón del hogar ha sido identificado como Rhamnus o Phillyrea. Se caracteriza por los vasos conductores que se distribuyen por todo el anillo anual de crecimiento formando flamas. El diámetro de los vasos es pequeño, de unos $20 \mu \mathrm{m}$ en el leño tardío, y en sus paredes tienen engrosamientos helicoidales. El límite anual de crecimiento es muy visible. El parénquima vertical es paratraqueal y metatraqueal. Los radios leñosos son heterogéneos de 2 o 3 células de ancho por unas 20 de alto.

Ambos géneros son arbustos que pueden alcanzar cierta altura; como no sabemos de qué especie se trata, no podemos precisar la ecología aunque ambos géneros tienen especies termófilas que viven desde el nivel del mar hasta los 1000 metros de altitud.

En definitiva, de la flora identificada en el campamento del Mesolítico del Cabezo de la Cruz se puede destacar:

1. Se han utilizado árboles, arbustos, matas y hierbas como leña para el fuego, aunque el conjunto presenta poca diversidad de plantas si lo comparamos con la ocupación de la Edad del Bronce o la del Hierro en el mismo yacimiento (Badal 2009). Se ha identificado un total de ocho plantas y dos han quedado indeterminadas por no estar bien conservada la estructura y ser de dimensiones muy pequeñas.
2. El hogar tiene más plantas leñosas que los carbones dispersos por el nivel de ocupación.

3. El pino carrasco sirvió como leña para el fuego y probablemente como postes para construir la cabaña. Habría que plantearse con qué herramientas cortaban la madera en el Mesolítico cuando todavía no había hachas de piedra pulimentada.

4. Coherencia ecológica de la flora documentada, ya que todas las plantas identificadas pueden vivir juntas en un mismo territorio porque tienen necesidades ecológicas similares.

5. Esta lista de flora prueba la utilización de la vegetación local como fuente de materias primas para la construcción y como combustible doméstico.

\subsubsection{RESULTADOS ANTRACOLÓGICOS}

Para hacer una interpretación del paisaje vegetal durante el Mesolítico en el valle del río Huerva, hemos calculado las frecuencias de las plantas identificadas. En la cuantificación de los resultados siempre se toma en consideración el contexto arqueológico de donde surgen los carbones porque pueden dar información diversa y/o complementaria (Chabal 1988; Badal 1992; Chabal et al . 1999; Carrión 2005). En el campamento mesolítico del Cabezo de la Cruz disponemos del conjunto de los carbones del Hogar (UE 1450) que, por la propia funcionalidad del mismo, debe responder a la leña quemada en la estructura antes de ser abandonado. Por otro lado, los carbones dispersos por el nivel de ocupación (UE 1351 y 1398) que pueden proceder de la dispersión desde su foco de origen: el hogar (fig. 1). Además contamos con el poste que formaba parte de la estructura de la cabaña (UE 1465) y dos troncos hallados en la superficie de la cabaña (UE 1397 y UE 1440) que tal vez procedan de la estructura de la misma y que fuera quemada. Con ese conjunto de carbones intentaremos plantear hipótesis etnográficas, paisajísticas y ecológicas.

En la figura 6, se representa gráficamente los porcentajes alcanzados por los taxa en ambos contextos arqueológicos: concentrados en el hogar y dispersos por el nivel mesolítico. Para facilitar la imagen gráfica hemos acumulado los datos de las dos unidades estratigráficas del nivel de ocupación (UE 135 y 1398). Tanto en la 


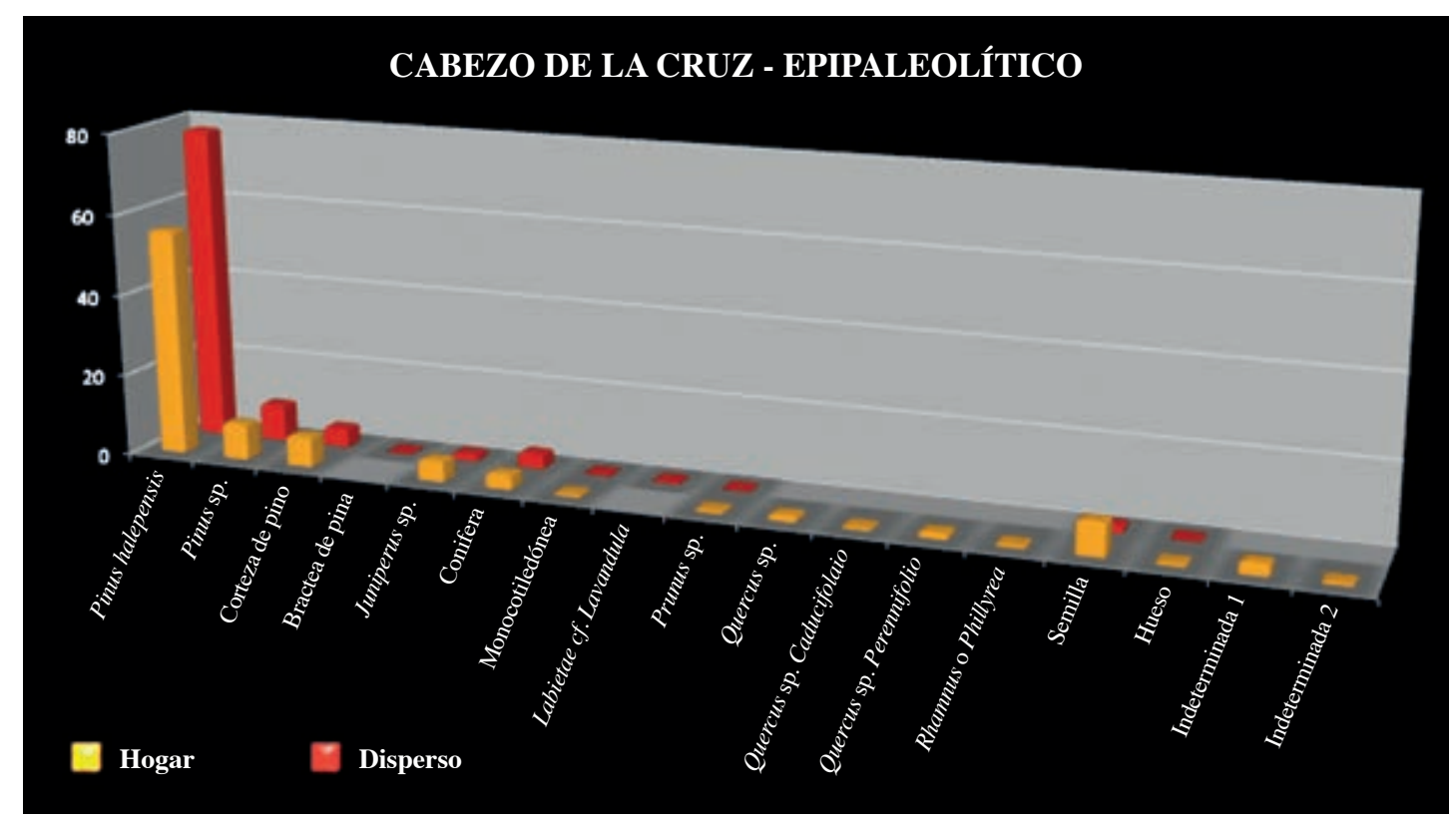

Figura 6. Resultados antracológicos del hogar y del nivel mesolítico en el Cabezo de la Cruz.

figura 1 como en la figura 6 se puede apreciar que el mayor porcentaje de restos carbonizados corresponde a Pinus halepensis (pino carrasco). En el hogar supone más del $50 \%$ y en el nivel de ocupación supera el $70 \%$ de los restos. De pino también se han identificado fragmentos amorfos de corteza y un fragmento de bráctea de piña del que no hemos podido identificar la especie, pero es muy probable que sean de pino carrasco, en base a la abundancia y exclusividad de carbones de este pino en todo el nivel mesolítico. Por tanto, si unimos todo tipo de restos de pino vemos una dominancia absoluta.

Las otras plantas identificadas tienen unos porcentajes muy bajos; la mayoría de ellas ni siquiera llegan al $1 \%$, pero son heraldos de diversidad floral en el territorio. Así los Quercus, tanto los caducifolios como los perennifolios, además de Prunus, Labietae, Monocotiledónea y Rhamnus o Phillyrea matizan la imagen monoespecífica que ofrecen los restos de pino carrasco.

Llama la atención que hay más diversidad de especies en el hogar que en los carbones dispersos por el nivel de ocupación, cuando normalmente ocurre lo contrario porque, como dijimos anteriormente, un hogar suele reflejar un periodo de tiempo más corto que el carbón disperso, por tanto, quedan sedimentadas menos las recogidas para leña. En los estudios antracológicos, el car- bón concentrado en un hogar se interpreta desde un punto de vista etnográfico, se intenta ver las pautas que siguieron los habitantes de un yacimiento en la selección de la leña (Heinz 1991; Badal 1992).

Los datos antracológicos del hogar (UE 1450) pueden ayudar a comprender los comportamientos humanos y la cadena de gestos que va desde la recogida de leña hasta la formación del yacimiento. Así, la diversidad de plantas halladas en el hogar mesolítico del Cabezo de la Cruz puede tener varias lecturas:

a) Que responde a una recogida de leña poco selectiva. Si las plantas identificadas se recogieron en una sola acción, entonces se recolectaron, al menos, siete plantas distintas. Lo que indica que toda leña arde a condición de que esté seca y que no se detecta una predilección hacia una especie en concreto.

b) Que responde a varias recogidas de leña. Si los carbones de la hoguera son el fruto de varias acciones de recolección de leña, entonces aunque los mesolíticos tengan un criterio constante de selección de la leña (p. ej., que prefieran al pino carrasco), siempre hay especies que escapan a esto y pueden quedar reflejadas en el hogar. Serían las plantas con bajos porcentajes (Quercus, monocotiledónea, Juniperus, etc.). 
c) Que la diversidad de plantas identificadas dependa del tipo de estructura de combustión. En el interior de la cabaña mesolítica se encontraba el hogar (UE 1450) en una cubeta circular de unos 50-60 cm de diámetro por unos $20 \mathrm{~cm}$ de profundidad (Picazo y Rodanés 2008); en su interior es donde se hallaron los 134 fragmentos de carbón de al menos siete plantas. En los estudios antracológicos de otros yacimientos se ha visto que este tipo de estructuras de combustión siempre son más ricas en taxones vegetales que los hogares planos o no estructurados (Heinz 1991; Badal 1992; Ntinou et al. 1999). Efectivamente, los hogares en fosa o en cubeta son más difíciles de limpiar y, aunque se vacíen de cenizas y carbones, siempre quedan restos en el fondo y en las paredes. Esto puede explicar la diversidad de la leña quemada en el hogar mesolítico del Cabezo de la Cruz.

d) Que la diversidad de flora responde al tiempo de utilización de la estructura. El factor tiempo en Prehistoria es difícil de aprehender, pero se puede postular que un hogar doméstico de uso cotidiano presenta más diversidad de leña que uno realizado puntualmente, al menos esto es así etnográficamente (Ntinou 2002). En este sentido el hogar mesolítico, aquí tratado, puede haber funcionado durante un cierto periodo de tiempo, sin poder precisar cuánto, y dio lugar a usar varias leñas.

En definitiva, la variedad de plantas utilizadas en el hogar puede responder a varias causas y, en todo caso, algunas de las plantas utilizadas en la estructura no quedaron reflejadas en los carbones dispersos por la cabaña mesolítica, tal vez porque los habitantes fueron a tirar la basura lejos de la cabaña o porque quemaran poca cantidad de esas plantas.

La cuantificación de los resultados antracológicos, tanto del hogar como de los carbones dispersos por el nivel de ocupación, dan el mayor protagonismo al pino carrasco (fig. 6). Las otras plantas apenas han dejado restos. Los porcentajes obtenidos se deben considerar con precaución por varias razones. En los análisis antracológicos de hogares prehistóricos se ha demostrado que casi siempre hay algún taxón que alcanza porcentajes muy altos, del orden del 80-90\% de los restos y que las áreas circundantes a un hogar suelen te- ner la misma tendencia (Heinz 1991; Badal 1992; Chabal et al. 1999). Esta podría ser una explicación de los resultados obtenidos en el campamento mesolítico del Cabezo de la Cruz, donde los restos de pino alcanzan más del $90 \%$ en el carbón disperso y más del $70 \%$ en el hogar; por tanto, con estos datos es muy arriesgado hacer una valoración cuantitativa del paisaje vegetal. Por otro lado, parece que la cabaña sufrió un incendio y en consecuencia se quemaron los postes estructurales, que eran de pino carrasco, lo que también puede explicar los altos porcentajes de los restos carbonizados de este pino en los carbones dispersos por el interior y exterior de la cabaña. De todos modos, el hecho de que la mayoría de los restos carbonizados sean de pino carrasco puede indicar que su biomasa fue la más explotada como combustible y como madera de construcción. Es muy probable que el pino carrasco formara pinares por amplias zonas del valle del río Huerva pero no podemos excluir otras formaciones como la de ribera, de la que no ha quedado registrado ningún elemento. Así que nuestra argumentación paleoecológica se basará en la presencia de los taxones y sus necesidades ecológicas.

\subsubsection{El PINO CARRASCO: ¿PIONERO Y CLÍMAX?}

La imagen que obtenemos a partir de los carbones es el reflejo del entorno inmediato a los hábitats. Los grupos prehistóricos utilizan los recursos disponibles en cada zona, en este caso, los vegetales. Las plantas tienen una distribución espacial que responde a sus necesidades ecológicas, generalmente temperatura, humedad y suelos son los factores más importantes en el área de distribución de los vegetales. La sola presencia de una especie vegetal puede ofrecer una información valiosa sobre temperatura y humedad. Combinando toda la flora documentada en un yacimiento se puede hacer una evaluación medioambiental de la zona en un periodo cronológico-cultural.

El asentamiento mesolítico del Cabezo de la Cruz, como dijimos al principio, es interesante porque se trata de sociedades cazadoras-recolectoras que vivieron en el valle del Ebro en uno de los momentos climáticos más benignos del Holoceno, es decir, el Atlántico. Por tanto, las plantas que utilizaron son el reflejo de la vegetación natural del valle y supuestamente el clímax de las formaciones vegetales holocenas previas a la llegada de la tecnología agrícola. La tecnología neolítica, 
no lo olvidemos, supone la primera llegada de plantas exóticas a la Península Ibérica como son los cereales y legumbres domésticas. Así pues, los habitantes mesolíticos del Cabezo de la Cruz desconocían esa tecnología y su sistema de producción se basaba en la utilización de los recursos silvestres.

El pino carrasco acapara nuestra atención por la cantidad que hay de sus restos en el campamento mesolítico y nos centraremos en él como bioindicador de condiciones climáticas y culturales. Su carácter termófilo, xérico y frugal lo convierten en una especie muy competitiva para ocupar zonas con climas cálidos, secos y suelos pobres. Por tanto, se convierte en un buen indicador de ciertos parámetros ecológicos. En la actualidad, su distribución altitudinal y latitudinal queda reflejada en la figura 1 donde también está situado el yacimiento de Cabezo de la Cruz que, como se puede observar, cae dentro de su área de distribución actual. El pino carrasco, como ya dijimos, tiene una preferencia costera aunque en la actualidad penetra bastante hacia el interior, sobre todo en el valle del Ebro. Pero, ¿desde cuándo habita en el valle del Ebro el pino carrasco? Haremos una breve revisión de la presencia de pino carrasco en la Península Ibérica. Para ello, tomaremos en consideración los macrorrestos vegetales por ser prueba directa de que fueron usados por los humanos y, por tanto, imagen directa de la flora local de cada yacimiento.

En la Península Ibérica, la presencia del pino carrasco en el Paleolítico Superior es muy puntual y, por el momento, se limita a la costa del sur de Andalucía, donde se ha identificado en pequeñas cantidades desde los niveles solutrenses de la Cueva de Nerja (Málaga) (Badal 1998). No se ha identificado en otras secuencias paleolíticas de la región (Carrión et al. 2008; Jenning et al. 2009), lo que puede avalar la hipótesis de su reducida área de distribución durante el Último Glacial. A partir del Tardiglacial, también se detecta en yacimientos costeros de Alicante como la Cova de les Cendres, Cova Bolumini y Santa Maira (Badal 1995; Badal y Carrión 2001; Aura et al. 2005). En Cataluña no se ha identificado en secuencias pleistocenas. En Aragón hay un vacío documental para el Paleolítico Superior, así que desconocemos la flora de la región para esos momentos. Por tanto, se puede plantear que las bajas temperaturas del Estadio Isotópico de Oxígeno 2 debieron ser un factor limitante a la expansión del pino carrasco por la vertiente mediterránea de la Península Ibérica, de tal modo que su área de distribución estaría muy fragmentada y probablemente limitada al sur y este peninsular. Este pino no tolera que la temperatura mínima del mes más frío sea inferior a $-3{ }^{\circ} \mathrm{C}$ (Gil et al. 1996), por tanto, la ausencia de este pino en las regiones costeras y a baja altitud, donde sí se ha documentado ampliamente la presencia de Pinus nigra y/o Pinus sylvestris avalan el descenso altitudinal y latitudinal de los pisos bioclimáticos durante el último glacial (Badal y Carrión 2001). De todos modos, sería recomendable hacer alguna datación AMS sobre carbones pleistocenos de pino carrasco para comprobar su pervivencia en las zonas más cálidas de la Península Ibérica durante el Último Glacial y así ir perfilando los refugios de las especies termófilas.

A partir del Holoceno, Pinus halepensis empieza una progresiva expansión en el espacio y en el tiempo, aunque tenemos un vacío documental para amplias zonas porque en muchos yacimientos todavía no se realizan recogidas sistemáticas de carbones de tal modo que impide conocer el tránsito Pleistoceno-Holoceno con precisión. No obstante, y a pesar de los datos fragmentarios de que disponemos, se observa que sus restos van apareciendo de forma tímida, tanto en yacimientos litorales como en el interior del este peninsular. En La Falguera (Alcoy, Alicante) se han datado dos carbones de Pinus halepensis por AMS y

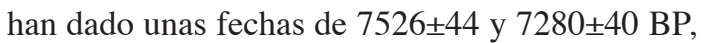
respectivamente (fig. 2) (Carrión 2002; Carrión et al. 2006; García y Aura 2006). No obstante, los restos de pino carrasco son testimoniales ya que el diagrama antracológico está dominado por los restos de Quercus tanto perennifolios como caducifolios y hay buena representación de otros caducifolios como fresnos, arces, Prunus, etc. (Carrión 2002, 2005). En Cataluña destaca el yacimiento de La Cativera (El Catllar, Tarragona) que tiene un nivel con industria del mesolítico microlaminar $(8860 \pm 95 \mathrm{BP})$ y otro macrolítico

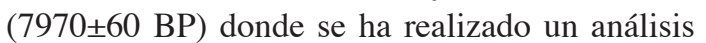
antracológico (Allué 2002). En ambos, los restos carbonizados de Pinus halepensis son abundantes y llegan a más del $30 \%$ en el nivel más reciente. Los otros taxa acompañantes son Quercus perennifolios y caducifolios, arces, madroño, rosáceas, etc. (Allué 2002). En el valle del Ebro, Pinus halepensis se presenta en el campamento al aire libre 
del Cabezo de la Cruz y en el abrigo de Los Baños de Ariño (Ariño, Teruel) (Badal 2004). En ambos casos hay una flora similar y la diferencia más notable la marca la presencia de Pinus nigra en Los Baños, dando una tonalidad más fría en esa zona del valle del Ebro. Ambos pinos pueden convivir en los límites de sus áreas de distribución, como se aprecia en la figura 3.

Las fechas radiocarbono obtenidas directamente en los carbones de Pinus halepensis muestran una sincronía entre su presencia en el abrigo de La Falguera y el Cabezo de la Cruz (fig. 2). Ahora bien, la flora acompañante marca la diferencia entre las dos regiones. En La Falguera los espectros antracológicos están dominados por los Quercus caducifolios, Quercus perennifolios y fresnos, mientras que los restos de pino carrasco no llegan al $5 \%$ (Carrión et al. 2006). Estos espectros nos hablan de un régimen pluviométrico mucho más elevado en La Falaguera (Alcoy, Alicante) que en el Cabezo de la Cruz (La Muela, Zaragoza) donde las plantas más exigentes en humedad (Quercus, Prunus) apenas están representadas y algo similar se puede decir para La Cativera, donde la flora más exigente en humedad tampoco tiene elevados porcentajes en los restos carbonizados. En base a esa proporción de la flora, podemos postular unas precipitaciones de tipo seco en el valle del Ebro, es decir, entre 350-600 mm de precipitación media anual y subhúmedo en Alcoy, es decir, 600$1000 \mathrm{~mm}$ de media anual.

Otra gran diferencia la marca la presencia de Olea europaea (olivo silvestre) que es la especie más termófila de las identificadas en la Falaguera (Carrión et al. 2006) y que está ausente en el valle del Ebro (Badal 2004) y en La Cativera (Allué 2002) lo que indica que estas zonas están bajo unas condiciones bioclimáticas de tipo mesomediterráneas, esto quiere decir que la temperatura media anual estaría comprendida entre 13 a $17^{\circ} \mathrm{C}$, mientras que en La Falguera aunque también fuera mesomediterráneo, se nota la influencia de la cercana zona termomediterránea y menor continentalidad que en el valle del Ebro.

A partir del $6500 \mathrm{BP}$, el pino carrasco aparece en muchos más yacimientos de la costa mediterránea peninsular pero también del interior; las dataciones radiocarbono lo confirman (fig. 2). No haremos una revisión exhaustiva pero sus restos se hallan en muchos yacimientos neolíticos de la costa de Andalucía, Alicante, Valencia, Tarragona y hasta el sur de Barcelona aunque normalmente dominan los restos de Quercus y otras frondosas (Ros 1985, 1992; Badal et al. 1994; Allué 2002; Carrión 2002, 2005). Su expansión y competencia con las fagáceas y otras frondosas debió comenzar a finales del Neolítico y se va consolidando su presencia durante la edad de los Metales en más zonas de Extremadura, Andalucía, País Valenciano y Cataluña (Rodríguez-Ariza 1992; Ros 1992; Duque 2004; Martín y Piqué 2008). En las zonas bajas del valle del Ebro, los datos antracológicos postulan que el pino carrasco continuó como vegetación dominante durante la Edad del Bronce y del Hierro (Carrión 2007; Badal 2009).

Con esta breve síntesis sobre la presencia de Pinus halepensis en la Península Ibérica, en general, y en el valle del Ebro, en particular, se puede concluir:

A) El pino carrasco parece que perduró en el sur peninsular durante el Último Máximo Glacial, pero sería aconsejable hacer dataciones AMS sobre sus restos para comprobar dicha hipótesis. Por otro lado, sería necesario tener secuencias antracológicas del Paleolítico en el valle del Ebro para conocer con mayor precisión la flora de estos territorios en el Último Glacial.

B) A principios del Holoceno, en los yacimientos litorales, los restos de pino carrasco se presentan en minoría en relación con las quercíneas y frondosas. Sus macrorrestos carbonizados son heraldos del cambio climático de inicios del Holoceno que pueden significar aumento de temperaturas y de xericidad.

C) En ciertas zonas del valle del Ebro (Cabezo de la Cruz, Los Baños) parece que formó la vegetación clímax del período Atlántico y es posible que la zona litoral de Tarragona también formara núcleos importantes.

D) Para el Mesolítico del Cabezo de la Cruz se puede plantear un hipótesis paleoclimática a partir de los rangos de tolerancia térmica y de humedad del pino carrasco. Es decir, como puede vivir entre los 12 y los $19^{\circ} \mathrm{C}$ de temperatura media anual y con unas lluvias mínimas de $250 \mathrm{~mm}$ hasta los $700 \mathrm{~mm}$ de media anual, es evidente que el clima durante el Mesolítico en el Cabezo de la Cruz estaba entre esos rangos térmicos y de humedad. Si tenemos en cuenta que no se encuentran especies más termófilas, como Olea europaea, entonces 
postularíamos un clima con temperatura media anual entre 12 y $17^{\circ} \mathrm{C}$, en cuanto a la humedad, visto el papel minoritario de las quercíneas nos inclinamos a pensar en unas lluvias de tipo seco.

E) Durante la Edad de los Metales el pino carrasco permanece como vegetación dominante en el Cabezo de la Cruz y en otros yacimientos contemporáneos en el valle del Ebro (Pérez et al. 2008; Badal 2009; Carrión 2009).

F) Su expansión y consolidación a lo largo del Sub-boreal y Subaltántico pudo estar favorecida por su carácter competitivo, frugal y tolerante, frente a las necesidades ecológicas de las frondosas (Quercus, Acer, Fraxinus, etc.) que son mucho más exigentes en humedad, suelos ricos en nutrientes, etc.

G) No se descarta la contribución de las actividades humanas en los territorios, a partir de la introducción de la agricultura y ganadería, como factor que favoreciera la expansión de Pinus halepensis en los periodos más recientes de la Prehistoria. Pero tampoco se descarta los efectos de un aumento de xericidad y temperatura en el este peninsular a partir de Sub-boreal en la propagación del pino carrasco.

H) En todo caso, los datos aportados por el análisis antracológico del Cabezo de la Cruz dan la razón a J. Braun-Blanquet y O. de Bolòs (1957, 39), quienes describen el dominio climático del pino carrasco (Pinus halepensis) con coscoja (Quercus coccifera) en zonas del valle del Ebro entre los 350 y los 700 metros de altitud con un clima mediterráneo semiárido. Es evidente que los carbones mesolíticos repoden a la vegetación clímax de la zona durante el Mesolítico, es decir, mucho antes de la introducción de la agricultura y la ganadería. Como narran J. Braun-Blanquet y O. de Bolòs, en relación con la vegetación del valle del Ebro durante la década de 1950: «Hay grandes superficies recubiertas por el Pinus halepensis, frecuentemente parasitado por el Viscum album, con un sotobosque de Quercus coccifera o arbustos del Rosmarino-Ericion; sin embargo, no se deja crecer a los árboles y el aspecto de las poblaciones es deplorable, excepto en las parcelas que están bajo vigilancia del servicio forestal y que se hallan por lo general en mejor estado» (Braun-Blanquet y Bolòs 1957, 48). Por tanto, es posible que desde el Neolítico el pino carrasco se beneficiara de las actividades agrarias para su pro- pagación pero también es cierto que, en otros momentos de la historia, justamente las actividades humanas en el territorio han puesto en riesgo los pinares de carrasco.

\section{BIBLIOGRAFÍA}

AlluÉ, E. 2002: Dinámica de la vegetación y explotación del combustible leñoso durante el Pleistoceno superior y el Holoceno del noreste de la Península Ibérica a partir del análisis antracológico. Tesis doctoral. Universidad Rovira i Virgili. Tarragona.

Aura, J.E., CARrión, Y., Estelles, E. y PÉrez, G. 2005: «Plant economy of hunter-gatherer groups at the end of the last Ice Age: plant macroremains from the cave of Santa Maira (Alacant, Spain) ca. 12000-9000 B.P». Vegetation History and Archaeobotany, 14: 542-550.

BADAL, E. 1992: «L'anthracologie préhistorique: à propos de certaines problèmes méthodologiques». Bull. Soc. Bot. Fr., 139. Actual. Bot. (3/3/4): 167-189.

—, 1995: «La vegetación carbonizada. Resultados antracológicos del País valenciano». El cuaternario en el País Valenciano. Universidad de Valencia. Valencia, 217-226.

—, 1998: «El interés económico del pino piñonero para los habitantes de la Cueva de Nerja». En Sanchidián, J.L. y Simón, M.D. (eds.): Las culturas del Pleistoceno superior en Andalucía. Patronato de la Cueva de Nerja. Nerja, 287-300.

—, 2004: «Análisis antracológico de los restos del fuego doméstico del abrigo de Los Baños (Ariño, Teruel)». En Utrilla, P. y Rodanés, J.M. ${ }^{\text {a } 2004: ~ U n}$ asentamiento mesolítico en el valle del río Martín. El abrigo de los Baños (Ariño, Teruel). Monografías 39. Universidad de Zaragoza. Zaragoza, 63-73.

—, 2009: «El combustible y el paisaje vegetal». En Picazo, J. y Rodanés, J.M.: Los poblados del Bronce Final y Primera Edad del Hierro. Cabezo de la Cruz. La Muela, Zaragoza. Gobierno de Aragón. Zaragoza, 132-155.

BADAl, E., BERnABÉU, J. y VERNET, J.L. 1994: «Vegetation changes and human action from the Neolithic to the Bronze Age (7000-4000 BP) in Alicante, Spain, based on charcoal analisis». Vegetation History and Archaeobotany, 3: 155-166. 
BADAL, E. y CARRIÓN, Y. 2001: «Del Glaciar al Interglaciar: los paisajes vegetales a partir de los restos carbonizados hallados en las cuevas de Alicante». En Villaverde, V. (ed.): De Neandertales a Cromañones. El inicio del poblamiento humano en tierras valencianas. Universidad de Valencia. Valencia, 21-40.

Bellot, F. 1978: El tapiz vegetal de la Península Ibérica. H. Blume. 423 p. Madrid.

Bernabéu, J., PÉrez, M. y Martínez, R. 1999: «Huesos, neolitización y contextos arqueológicos aparentes». En Bernabéu, J. y Orozco, T. (eds.): Actes del II Congrès del Neolitic a la Península Ibérica. Saguntum-PLAV. Extra-2: 589-596.

BRAUN-BlANQUET, J. y Bolòs, O. de. 1957: Las comunidades vegetales de la depresión del Ebro y su dinamismo. Edición en castellano 1987. Ayuntamiento de Zaragoza. 278 p. Zaragoza.

CÁmara, J.A., Molina, F. y AfONSO, J.A. 2005: «La cronología absoluta de Los Castillejos en Las Peñas de los Gitanos (Montefrío, Granada)». En Arias, P., Ontañón, R., García-Moncó, C. (eds.): III Congreso del Neolítico en la Península Ibérica. Universidad de Cantabria. Santander, 841-852.

Carrión, J.S., Finlayson, C., Fernández, S., Finlayson, G., Allué, E., LóPEZ-SÁEZ, J.A., LóPez-GARCíA, P., GIL-RoMERA, G., BAILEY, G. y GONZÁlEZ-SAMPÉRIZ, P. 2008: «A coastal reservoir of biodiversity for Upper Pleistocene human populations: palaeoecological investigations in Gorham's Cave (Gibraltar) in the context of the Iberian Peninsula». Quaternary Science Reviews, 27: 2118-2135.

CARrión, Y. 2002: "Charcoal analysis at La Falaguera rockshelter (Alcoi, Alacant) from Mesolithic to Bronze Age: landscape and wood uses». En Thiébault, S. (ed.): Charcoal Analysis. Methodological Approaches, Palaeoecological Results and Wood Uses. BAR Internacional Series 1063, Archaeopress. Oxford, 103-108.

- , 2005: La vegetación mediterránea y atlántica de la Península Ibérica. Nuevas secuencias antracológicas. Serie de Trabajos Varios del SIP. 104. 314 p. Diputación de Valencia. Valencia.

- , 2007: «Woodland in the middle Ebro valley (Spain). Dendro-logical analyses of archaeological timber from Bell Baker and Iron Age periods». Archéosciences, 31: 151-162.
Carrión, Y., Molina, Ll., PÉrez, M., García, O., Pérez, G., Verdasco, C. y Mcclure, S.B. 2006: «Las evidencias de una orientación ganadera. Los datos». En García, O. y Aura, J.E. (coords.): El Abric de La Falguera (Alcoi, alacant). 8000 años de ocupación humana en la cabecera del río Alcoi. Diputación de Alicante. Ayuntamiento de Alcoy. Caja de Ahorros del Mediterráneo. Alcoy, 219-236.

CHABAL, L. 1988: «Pourquoi et comment prélever les charbons de bois pour la période antique: les méthodes utilisées sur le site de Lattes (Hérault)». Lattara, 1: 187-222.

Chabal, L., Fabre, L., Terral. J.-F. y TheryPARISOT, I. 1999: L'anthracologie. En BourquinMignot, C., Brochier, J.-E., Chabal, L., Crozat, S., Fabre, L., Guibal, F., Marinval, P., Richard, H., Terral, J.-F., Thery-Parisot, I.: La Botanique. Collection Archéologiques. Errance. París, 43-104.

Costa, M., Morla, C. y SÁInZ, H. 2001: Los bosques ibéricos. Una interpretación geobotánica. Planeta. 597 p. Barcelona.

DUQUE, D.M. 2004: La gestión del paisaje vegetal en la Prehistoria reciente y Protohistoria en la cuenca media del Guadiana, a partir de la Antracología. Tesis doctoral. Universidad de Extremadura.

GARcíA, O. y AurA, J.E. (coords.) 2006: El Abric de La Falguera (Alcoi, alacant). 8000 años de ocupación humana en la cabecera del río Alcoi. Diputación de Alicante, Ayuntamiento de Alcoy. Caja de Ahorros del Mediterráneo. 301 p. Alcoy.

GARCÍA, O. y MOLINA, L. 2005: «La secuencia prehistórica de l'Abric de La Falguera (Alcoi, Alacant). Las ocupaciones del Mesolítico Reciente y del Neolítico». En Arias, P., Ontañón, R. y García-Moncó, C. (eds.): III Congreso del Neolítico en la Península Ibérica. Universidad de Cantabria. Santander, 893-901.

GIL, L. 2008: Pinares y rodenales. La diversidad que no se ve. Real Academia de Ingeniería. 191 p. Madrid.

Gil, L., DíAZ-FERnÁndEZ, P.M., JimÉnEZ, M. ${ }^{\mathrm{a}}$ P., Roldán, M., AlíA, R., AgúndeZ, D., DE Miguel, J., Martín, S. y DE TuERo, M. 1996: Las regiones de procedencia de Pinus halepensis Mill. en España. Organismo Autónomo Parques Naturales. 113 p. Madrid. 
HeINZ, C. 1991: «Upper Pleistocene and Holocene vegetation in the south of France and Andorra. Adptations and firts ruptures: New charcoal analysis data». Review of Palaeobotany and Palynology, 69: 299-324.

JACAMON, M. 1979: Guide de dendrologie. ENGREF. Nancy.

JACQUIOT, C. 1955: Atlas d'Anatomie des Bois de Conifères. Cent. Techn. Bois, 133 p. París.

JaCQuiot, C., Trenard, Y. e Hidrol, D. 1973: Atlas d'anatomie des bois des angiospermes (Essences feuillues). Cent. Techn. Bois. 175 p. París.

JENNINGS, R.P., GILES, F., BARTON, R.N.E., Collcutt, S.N., Gale, R., Gleed-Owen, C.P., Higham, T.F.G., PARKer, A., Price, C., Rhodes, E., Santiago, A., Schwenninger, J.L. y TurNER, E. 2009: «New dates and palaeoenvironmental evidence for the Middle to Upper Palaeolithic occupation of Higueral de la Valleja Cave, southern Spain». Quaternary Science Reviews, 28 (910): $830-839$.

MARTín, M. y PiQuÉ, R. 2008: «Consumo especializado de combustible en el neolítico: los datos antracológicos del yacimiento de Auvelles (Castelló de Farfanya, Lleida)». En Hernández, M., Soler, J.A. y López, J.A. (eds.): IV Congreso del Neolítico Peninsular. Tomo I. Alicante, 432-437.

NTINOU, M., 2002: El paisaje en el norte de Grecia desde el Tardiglaciar al Atlántico. Formaciones vegetales, recursos y usos. BAR. International Series 1038.

NTINOU, M., BADAL, E. y HeInZ, Ch. 1999: «Resultados preliminares del proyecto etnoarqueológico de Sarakini (Tracia, Grecia). Comparación con la antracología prehistórica». Geomorfología y Cuaternario litoral. Memorial M.P. Fumanal. Universidad de Valencia. Valencia, 179-191.

PeinAdo, M. y Rivas-Martínez, S. (eds.) 1987: La vegetación de España. Universidad de Alcalá de Henares. 544 p. Alcalá de Henares.

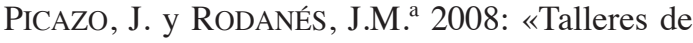
sílex, poblados y aldeas. Una cabaña mesolítica en el Cabezo de la Cruz (La Muela, Zaragoza)». En Hernández, M., Soler, J.A. y López, J.A. (eds.): IV Congreso del Neolítico Peninsular. Tomo I. Alicante, 137-142.

-, 2009: Los poblados del Bronce Final y Primera Edad del Hierro. Cabezo de la Cruz. La Muela, Zaragoza. 496 p. Gobierno de Aragón. Zaragoza.
Pérez, G., Carrión, Y., Valcárcel, A. y BuRILLO, F. 2008: «La integración de los materiales arqueobotánicos y el estudio funcional y espacial de la ciudad celtíbera de Segeda». En Rovira, S., García-Heras, M., Gener, M. y Montero, I.: Actas VII Congreso Ibérico de Arqueometría. Edición electrónica. ISBN 978-84-612-8598-3.

RoDANÉS, J.M. y y PICAZO, J. 2006: Caminos para el futuro, ventanas hacia el pasado. El Cabezo de la Cruz, una comunidad agraria de la Edad del Hierro en el valle del Ebro. Gobierno de Aragón. Diputación Provincial de Zaragoza y Ministerio de Fomento. Zaragoza.

RODRÍGUEZ-ARIZA, M.O. 1992a: Las relaciones hombre-vegetación en el Sureste de la Península Ibérica durante las Edades del Cobre y Bronce a partir del análisis antracológico de siete yacimientos arqueológicos. Tesis doctoral microfilmada. Universidad de Granada.

—, 1992b: «Humans-plant relationships during the Copper and Bronze Ages in the Baza and Guadix basins (Granada, Spain)». En Vernet, J.L. (ed.): Les charbons de bois, les anciens écosystèmes et le rôle de l'Homme. Bull. Soc. bot. Fr. 139, Actual. bot. (2/3/4): 451-464.

Ros, M. ${ }^{a}$ T. 1985: Contribució antracoanalítica a l'estudi de l'entorn vegetal de l'home del Paleolític superior a l'edat del ferro a Catalunya. Tesis de licenciatura. Universidad Autónoma. Barcelona.

—, 1992: «Contribution of charcoal analysis to the study of vegetal palaeoenvironment in Catalonia (Spain)». En Vernet, J.L. (ed.): Les charbons de bois, les anciens écosystèmes et le rôle de l'Homme. Bull. Soc. bot. Fr. 139, Actual. bot. (2/3/4), 483-494.

Ruiz-TABoAda, A. y Montero, I. 1999: «Ocupaciones neolíticas en el Cerro de la Virtud. Estratigrafía y dataciones». En Bernabéu, J. y Orozco, T. (eds.): Actes del II Congrès del Neolitic a la Península Ibérica. Saguntum-PLAV, Extra-2: 207-211.

SCHWEINGRUBER, F. 1990: Anatomie europäischer Hölzer. Ein Atlas zur Bestimmung europäischer Baum-Strauch und Zwergstrauchhölzer. Haupt, 800 p. Stuttgart.

Vernet, J.L., BAZILE-Robert, E. y EVIN, J. 1979: «Coordination des analyses anthracologiques et des datations absolues sur charbons des bois». Bull. Soc. Préhist. Fr., 76: 76-79. 


\subsection{EL REFLEJO DEL PAISAJE VEGETAL DEL HOLOCENO MEDIO \\ EN EL VIII MILENIO BP \\ EN EL YACIMIENTO ARQUEOLÓGICO DEL CABEZO DE LA CRUZ \\ (LA MUELA, ZARAGOZA) Y SU ENTORNO}

\section{M. a JOSÉ IRIARTE CHIAPUSSO*}

\subsubsection{INTRODUCCIÓN}

Los resultados expuestos en este texto completan el estudio paleopalinológico del yacimiento arqueológico del Cabezo de la Cruz, cuya referencia a los niveles de inicio del Holoceno reciente han sido publicados en la monografía correspondiente (Picazo y Rodanés 2009). Tal y como se indica en dicha publicación (Iriarte 2009), el asentamiento del Cabezo de la Cruz se ubica en un cerro de la margen izquierda del río Huerva, en el límite de los municipios de La Muela y Mozota, en una altiplanicie de unos $600 \mathrm{~m}$ de altitud. El clima actual de esta zona geográfica tiene un marcado carácter mediterráneo continental, con unas precipitaciones escasas e irregulares y un considerable contraste de temperaturas. La intensidad de la presión antrópica sobre este territorio ha condicionado notablemente la evolución de su paisaje vegetal, caracterizado por un predominio de las comunidades herbáceas-arbustivas como sabinares, coscojares, romerales-tomillares o sisallares, propias de las etapas seriales de sustitución de las masas boscosas como los pinares y carrascales, las cuales se refugian en enclaves muy determinados. Asimismo, la acción humana ha limitado el desarrollo de la vegetación de ribera, en la que destacan los carrizales, juncales y tamarizales, encontrándose en las áreas menos alteradas sauces, álamos, fresnos y olmos.

En el presente trabajo, nos centramos en los niveles asociados a la primera ocupación del cerro, correspondientes a un campamento temporal mesolítico ubicado en la ladera baja del cabezo. Tras este asentamiento de finales del VI milenio a. C., no será hasta el Bronce final cuando se establezca el primer núcleo de habitación permanente, al que sucederán otros hasta el siglo $\mathrm{V}$ a. C. La torre medieval de vigilancia será la última estructura estable construida en el cerro.

\footnotetext{
* Grupo de Investigación de Alto Rendimiento de Prehistoria de la Universidad del País Vasco (IT288-07).
}

\subsubsection{Metodología del ANÁlisis POLÍNICO}

La metodología del estudio polínico comprende, principalmente, las siguientes fases: trabajo de campo (muestreo); tratamiento físico-químico del sedimento; recuento e identificación del contenido esporopolínico mediante microscopía óptica e interpretación de los resultados (Burjachs et al. 2003). A pesar de que en la publicación de los niveles protohistóricos ya se describen las características de estas fases, consideramos oportuno volver a mencionarlas centrándonos en las características específicas del nivel de ocupación epipaleolítica.

\section{Muestreo}

De las cinco columnas polínicas recogidas en el yacimiento arqueológico del Cabezo de la Cruz (fig. 1), los resultados que exponemos corresponden a las columnas C, D y E (16 muestras). Siguiendo un criterio crono-estratigráfico, la primera de ellas es la columna E (cuadro $41 \mathrm{E}$ : muestras 1 a 6 ), cuyo registro corresponde al nivel de arcillas naturales previo al primer asentamiento humano en el cabezo. Las unidades estratigráficas adscritas a las diferentes fases de ocupación epipaleolítica (Mesolítico geométrico: c. 5200-5000 a.C.) están representadas en las tres primeras muestras de la columna $\mathrm{C}$ (cuadro 41/39 C: muestras 1 a 3) y en la columna D (cuadro $41 \mathrm{C}$ : muestras 1 a 3). El resto de la columna $\mathrm{C}$ (muestras 4 a 7) coincide con el nivel de ladera de formación post-epipaleolítica.

\begin{tabular}{|ccc|}
\hline \multicolumn{2}{|c|}{ Cabezo de la Cruz } \\
Correlación de las muestras paleopalinológicas \\
\hline Ladera & & Columna C: \\
post-epipaleolítica & $\rightarrow$ & muestras 3 a 7 \\
UE 1637 \\
\hline & & Columna C: \\
muestras 1 y 2 \\
Nivel de ocupación: & & UE 1397 \\
EPIPALEOLÍTICO & $\rightarrow$ & $7130 \pm 130$ y 7150 \pm 70 BP \\
GEOMÉTRICO & & Columna D: \\
& & muestras 1 a 3 \\
& UE 1351 \\
\hline Ladera & $\rightarrow$ & Columna E: muestras 1 a 7 \\
pre-epipaleolítica & $\rightarrow$ & UE 1637 inf. \\
\hline
\end{tabular}

Figura 1. Localización de las columnas polínicas.

Tras la selección y limpieza de los cortes estratigráficos seleccionados, las muestras fueron recogidas en columna. En cada una de las muestras se recogió una cantidad aproximada de $100 \mathrm{~g}$ de sedimento, aplicando un intervalo de muestreo (entre 
3 y $9 \mathrm{~cm}$ ) inevitablemente condicionado por las características del sedimento. Asimismo, con la finalidad de evitar problemas de contaminación esporopolínica durante el proceso de muestreo, las muestras de cada columna se recogieron en orden inverso, comenzando por la muestra más antigua y terminando por la más reciente.

\section{Tratamiento físico-químico del sedimento}

El trabajo de laboratorio se inicia con el tratamiento físico (lavado con agua destilada y/o tamizado) cuyo objetivo es el de preparar el sedimento para el ataque posterior del mismo en el proceso químico. El tratamiento químico se inicia con un ataque de $\mathrm{HCl}$ para eliminar los carbonatos. Tras su neutralización, se añade $\mathrm{NaOH}$ al $20 \%$ (reacción en caliente - baño María-) para que actúe sobre los ácidos húmicos. Con la finalidad de separar el contenido polínico se utiliza el método de concentración del polen en licor denso (Goeury y Beaulieu 1979). Una vez filtrado, y eliminados los filtros y silicatos que pudieran existir, se procede al montaje del contenido esporopolínico recuperado en los respectivos portas para su identificación al microscopio. Como en todos los análisis efectuados por la autora de este estudio, desde hace ya más de quince años, el contenido esporopolínico de las muestras ha sido montado sobre una base de glicerina ligeramente fluida, que permite la movilidad de los restos en la preparación, optimizando así las posibilidades de su determinación.

\section{Recuento polínico}

Manteniendo el criterio basado en la relación entre el número de palinomorfos y el número de taxones presentes en un registro polínico, que ha sido empleado en los niveles protohistóricos de este yacimiento, se consideran polínicamente estériles aquellas muestras que no alcanzan la suma de los 100 pólenes y esporas y que presentan una variedad taxonómica inferior a 10 taxones. Por el contrario, se han considerado representativas aquellas muestras que presentan un elevado número de pólenes (próximo o superior a 200 efectivos) y cuya variedad taxonómica es superior a 15 . Sin embargo, tampoco se han considerado válidos aquellos valores superiores a 100 palinomorfos, e incluso superiores a 200 efectivos, correspondientes en su mayoría a un solo taxón, y acompañado de pocos taxones adicionales, como sucede en la muestra 6 de la columna E, en la que, de un total de 362 pólenes, 312 pertenecen a la familia de las quenopodiáceas (Chenopodiaceae).

\section{Representación de los resultados}

La representación gráfica escogida, atendiendo a los reducidos resultados obtenidos, ha sido el histograma. Los diferentes taxones que componen el estudio se representan en columnas verticales. Sus porcentajes se han calculado a partir de la suma total de AP, NAP, y Varia (indeterminables e indeterminados), mientras que los valores globales de AP, NAP y Esporas se calculan con relación a la suma total de pólenes y esporas existentes en cada muestra.

La nomenclatura empleada en el presente trabajo para denominar a los distintos taxones es la expuesta en las obras Flora Europaea y Flora Iberica (Tutin et al. 1980; Castroviejo et al. 1986 y 1990, respectivamente). Bajo la denominación Poaceae se incluyen los diversos géneros de gramíneas, mientras que la denominación Quercus robur tp. agrupa las especies de este género de hoja caduca y marcescente y la de Quercus ilex tp., las especies de hoja perenne (Quercus ilex y Quercus coccifera).

\section{Interpretación del análisis palinológico}

Los postulados de base para la interpretación de un análisis palinológico son los siguientes (Reille 1990; Iriarte 1994):

- La veracidad de los resultados depende principalmente de la precisión y de la meticulosidad del método empleado (muestreo, proceso de laboratorio, etc.).

- La lluvia polínica fósil refleja la vegetación antigua, de la misma forma que la lluvia polínica actual corresponde a la vegetación de hoy en día.

- La evolución de las distintas especies vegetales, en el Cuaternario, no ha producido variaciones sustanciales en las características morfológicas de la planta, ni en su ecología, permitiendo la comparación con especies actuales.

- La situación geográfica del yacimiento le conferirá unas características particulares en función de su altitud, latitud, orientación y posibilidad de utilización por hombres y animales.

La existencia de estos postulados no debe hacernos olvidar que la interpretación palinológica está ligada a las limitaciones y posibilidades que tiene el método. Atendiendo, de modo particular, a las distorsiones que la presencia humana puede originar sobre el medio vegetal, efectuando la necesaria lectura crítica de los indicadores correspondientes cuando sea preciso. 


\subsubsection{EL REGISTRO POLÍNICO DEl CABEzo de la CRUZ}

Los resultados obtenidos en el estudio paleopalinológico no han cubierto nuestras expectativas. No se ha podido obtener una muestra estadísticamente significativa. El nivel previo a la ocupación epipaleolítica es del que hemos recuperado mejor información. Las muestras E1, E2, E4 y E5 no han conservado ningún resto esporopolínico, mientras que en la muestra E3 únicamente se han recuperado dos pólenes de Pinus y 4 pólenes que, debido a su deficiente grado de conservación, no se pueden identificar.

La muestra E6 es la de mayor contenido esporopolínico recuperado (figs. 2 y 3). En total, se han identificado 368 palinomorfos que corresponden a 13 taxones diferentes: Pinus sp., Quercus ilex sp., Salix, Cistaceae, Poaceae, Artemisia, Chenopodiaceae, Compositae liguliflora, C. tubuliflora, Caryophyllaceae, Juncaceae, esporas monoletes y triletes. A pesar del significativo número de pólenes recuperados y de la variedad taxonómica, que se aproxima a la que consideramos estadísticamente válida, el modo en que se encuentran los pólenes no permite estimar esta muestra como estadísticamente representativa del entorno vegetal del sitio.

\begin{tabular}{|l|c|l|c|l|l|}
\hline \multicolumn{2}{|c|}{ Polen arbóreo } & \multicolumn{2}{|c|}{ Polen no arbóreo } & \multicolumn{2}{c|}{ Esporas } \\
\hline Pinus sp & 5 & Poaceae & 13 & F. monoletes & 3 \\
\hline Quercus ilex tp. & 3 & Chenopodiaceae & 312 & F. triletes & 3 \\
\hline Salix & 1 & Artemisia & 2 & & \\
\hline \multirow{5}{*}{} & C. liguliflora & 1 & \\
\cline { 2 - 4 } & C. tubuliflora & 2 & \\
\cline { 2 - 4 } & Cistaceae & 1 & \\
\cline { 2 - 4 } & Caryophyllaceae & 15 & \\
\cline { 2 - 4 } & & Cruciferae & 1 & \\
\cline { 2 - 4 } & Juncaceae & 2 & & \\
\hline Total pólenes & 9 & & 349 & Total esporas & 6 \\
\hline
\end{tabular}

Figura 2. Pólenes y esporas recuperados en la muestra E6.

En concreto, la mayoría de los pólenes corresponden a un solo taxón, Chenopodiaceae (312). Además, en este recuento no se incluyen una serie de grumos (agrupaciones o conjuntos de pólenes) ${ }^{1}$ cuya suma aportaría 115 palino-

1 Han aparecido 5 grumos de 3 pólenes, 1 grumo de 4 , 1 grumo de 5,1 grumo de 6,1 grumo de 7,1 grumo de 8,2 grumos de 9,1 grumo de 10 pólenes, 1 grumo de 14 y 1 grumo de 28 .
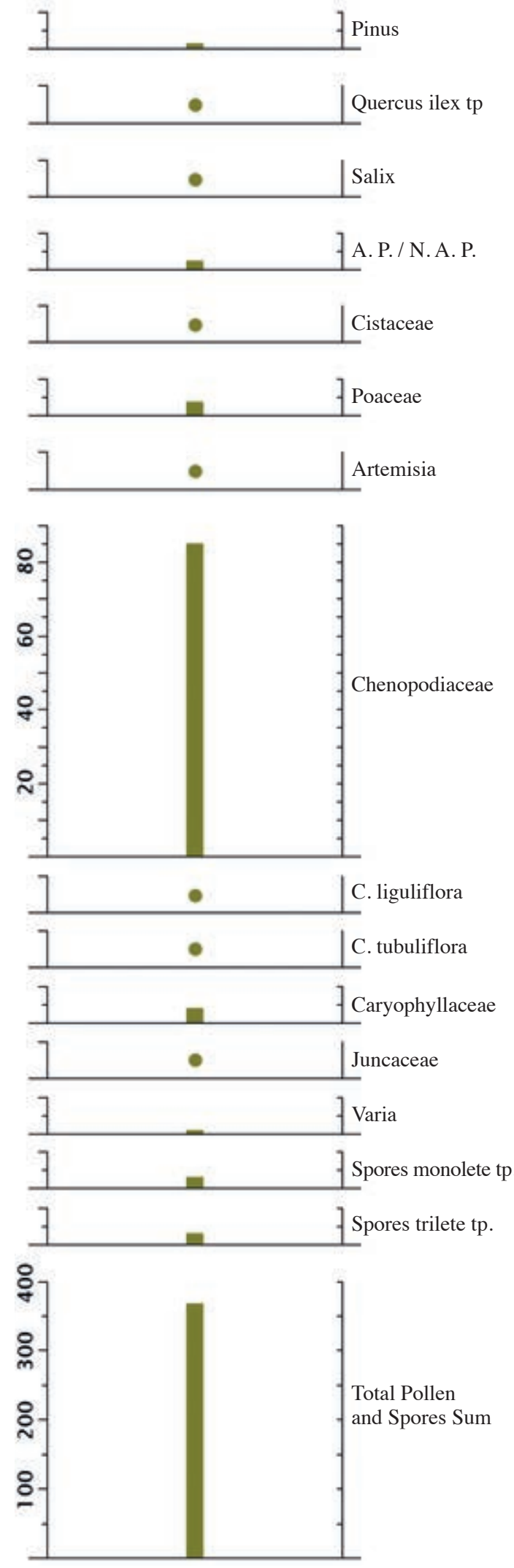

Figura 3. Columna E-muestra 6: representación gráfica de los resultados. 
morfos más (fig. 4). En el caso de las gramíneas (Poaceae) también ha aparecido un grumo de seis pólenes. Este tipo de representación no es característica de la deposición polínica (predominantemente anemófila) propia de un registro paleopalinológico y se suele asociar a otros procesos como la descomposición de los estambres de flores en el sedimento bien debido a procesos naturales o a la incorporación de plantas en el yacimiento (por ejemplo, a través de animales o de labores de recolección). Este mismo proceso se observó en algunas muestras de los niveles protohistóricos, como comentamos en la anterior publicación (Iriarte 2009). Teniendo en cuenta que el nivel al que pertenece esta muestra corresponde a una formación de ladera, previa a la ocupación epipaleolítica, sería lógico considerar que en este proceso no ha intervenido el ser humano. No obstante, en este nivel limo-arcilloso se ha constatado que se realizaron diversos trabajos de acondicionamiento y retalla para asentar la cabaña epipaleolítica, por lo que no puede descartarse la interferencia humana en este agrupamiento anómalo de los pólenes.

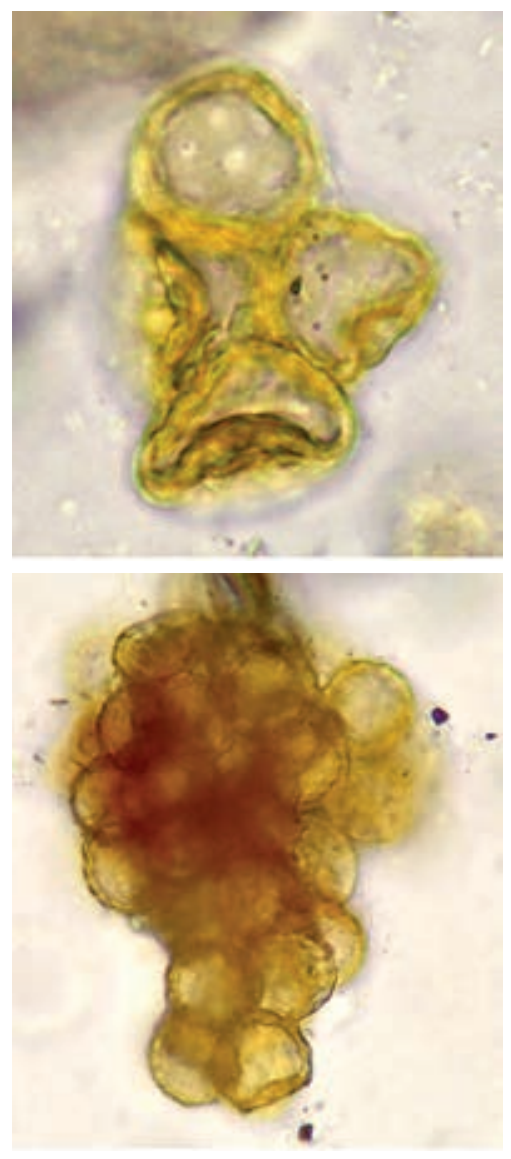

Figura 4. Grumos de Chenopodiaceae.
Desgraciadamente, el resto de las muestras del estudio paleopalinológico del asentamiento mesolítico del Cabezo de la Cruz se caracterizan por un deficiente grado de conservación esporopolínica (fig. 5). Por esta circunstancia no disponemos de ningún dato más sobre el entorno vegetal de este yacimiento en estos periodos del Holoceno.

\begin{tabular}{|c|c|c|c|c|c|c|c|c|c|c|c|c|c|c|}
\hline \multicolumn{15}{|c|}{ Cabezo de la Cruz } \\
\hline & \multicolumn{4}{|c|}{$\begin{array}{c}\text { Columna } \\
E\end{array}$} & \multicolumn{4}{|c|}{$\begin{array}{c}\text { Columna } \\
D\end{array}$} & \multicolumn{6}{|c|}{$\begin{array}{c}\text { Columna } \\
\text { C }\end{array}$} \\
\hline & 1 & 2. & & 5 & 1 & & & & 2 & & 4 & & & 7 \\
\hline Pinus $s p$. & - & - & & 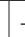 & - & . & & & & & - & - & -1 & - \\
\hline C. liguliflora & - & 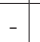 & & 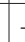 & - & . & & & - & & 1 & - & - & - \\
\hline Indeterminables & - & - & & . & 2 & . & & & - & - & - & - & - & - \\
\hline Esporas & - & - & & & - & & & & & & 1 & 1 & & - \\
\hline Total & - & - & & . & 2 & & & & 14 & & 2 & 1 & - & - \\
\hline
\end{tabular}

Figura 5. Contenido esporopolínico de las columnas $C, D$ y $E$.

Junto al escaso contenido esporopolínico conservado, en algunas de las muestras aparece Pseudoschizaea. Este microorganismo ha generado una prolífica bibliografía tanto sobre su clasificación, como sobre su nomenclatura ${ }^{2}$ y ecología (Wolff 1934; Rossignol 1962; Thiergart y Frantz 1962; Christopher 1976; Takahashi 1979). La opinión más generalizada, considera a este fósil no polínico como el quiste de una alga de agua dulce, en concreto, una alga verde perteneciente a la familia Zygnemataceae (Grenfell 1995).

Atendiendo al contexto paleoambiental en el que suelen aparecer estos microfósiles se deduce que vivían en las orillas de un variado espectro de depósitos (arroyos, charcas, lagos, llanuras aluviales, áreas deltaicas, etc.), llegando incluso a penetrar en áreas de marisma debido a la aportación en ellas de agua dulce procedente de los ríos (Medeanic et al. 2008). La presencia de Pseudoschizaea suele relacionarse con variaciones locales del nivel hídrico, en concreto, con inundaciones y desecaciones periódicas, como sequías estivales (Scott 1992; Alcalde et al. 2001-2002; Carrión y Navarro 2002; Y1l et al. 2003). En los contextos paleobotánicos donde aparece, los incrementos de Pseudoschizaea suelen coincidir con dinámicas contrarias en las curvas polínicas (descenso de los valores de frecuencia polínica) y con procesos erosivos. Por este motivo, se considera que este

2 Otros términos empleados para denominar a este microfósil son: Sporites, Concentrycystes e Hystrichospheros. 
fósil no polínico puede ser un indicador de fases erosivas relacionadas con alteraciones en la dinámica sedimentaria (Pantaleón-Cano et al. 1996).

En el caso del Cabezo de la Cruz, aparece de un modo esporádico y no en todas las muestras. Sin embargo, destacan los valores que presenta en las tres muestras más antiguas de la columna $\mathrm{C}$ adscritas a la UE 1397 y al inicio de la UE 1637 (fig. 6).

La presencia de este microorganismo, asociado a procesos de erosión, podría ser coincidente con la génesis de estas unidades estratigráficas. Las muestras $\mathrm{C} 1$ y $\mathrm{C} 2$ corresponden al proceso de sedimentación generado tras el abandono de la ocupación epipaleolítica y la muestra $\mathrm{C} 3$ al nivel de contacto entre esta unidad y el nivel de ladera posterior. Por lo tanto, podría indicar la existencia de algunos procesos erosivos durante la formación de estas unidades.

\begin{tabular}{|c|c|c|c|c|c|c|c|c|c|c|c|c|c|}
\hline \multicolumn{14}{|c|}{ Cabezo de la Cruz } \\
\hline & \multicolumn{4}{|c|}{$\begin{array}{c}\text { Columna } \\
E\end{array}$} & \multicolumn{3}{|c|}{$\begin{array}{c}\text { Columna } \\
D\end{array}$} & \multicolumn{6}{|c|}{$\begin{array}{c}\text { Columna } \\
\text { C }\end{array}$} \\
\hline & 1 & \begin{tabular}{l|l}
2 & 3 \\
\end{tabular} & 4 & 5 & 1 & 2 & 3 & 1 & 2 & 3 & 4 & & $6 \quad 7$ \\
\hline Pseudoschizaea & -1 & -1 & & - & - & 1 & - & 48 & 6 & 16 & & & 2 \\
\hline
\end{tabular}

Figura 6. Presencia de Pseudoschizaea.

\subsubsection{EL VIII MILENIO BP EN ARAGÓN Y SU CONTEXTUALIZACION CON EL REGISTRO DEL CABEZO DE LA CRUZ}

A pesar de los deficientes resultados obtenidos en este estudio, del registro polínico de la muestra E6 se pueden entrever algunos aspectos de las características de la vegetación del entorno previo a la ocupación mesolítica del Cabezo de la Cruz. Si bien no podemos determinar si en el paisaje predominaba la masa forestal o no, sí se confirma que el pino y los robles de hoja perenne (encina y/o coscoja) son los elementos más destacados dentro de la cubierta arbórea. También en el estrato herbáceo-arbustivo destacan los taxones propios de un ambiente mediterráneo, incluso de carácter estépico como Artemisia. Asimismo, queda constatada en el registro, la existencia de condiciones de humedad, posiblemente asociadas al curso de agua cercano. Estas circunstancias permitían que en su ribera existieran especies como el sauce, juncáceas y helechos.

Los depósitos aragoneses con una secuencia cronocultural similar a la primera ocupación del Cabezo de la Cruz son la cueva de Chaves y los abrigos de Peña 14, El Secans, El Pontet, Botiquería dels Moros y Los Baños (fig. 7).

Pese a la interesante secuencia cultural de la cueva de Chaves (Bastarás, Huesca) que comprende tanto niveles del Pleistoceno superior como de las dos primeras fases del Holoceno, los problemas de conservación esporopolínica limitan la información holocena a los niveles neolíticos, fechados en el VII milenio BP y, por tanto, posteriores al periodo que nos interesa (López García 1992; López García y López Sáez 2000).

En el abrigo de Peña 14 (Biel, Huesca) se suceden diversas ocupaciones humanas que comienzan en un nivel adscrito al Magdaleniense final-Mesolítico microlaminar $(10630 \pm 100,10430 \pm 190$, $10160 \pm 130$ BP). Tras un periodo sin ocupación humana (nivel c) tienen lugar las dos ocupaciones mesolítica (Montes 2001-2002): Mesolítico macrolítico (nivel b: $8780 \pm 110,8340 \pm 130,8000 \pm 90$ y $8000 \pm 80$ BP) y Mesolítico geométrico (nivel a: $7660 \pm 90$ BP). Durante el IX milenio BP, en el paisaje de esta zona de Biel, se produce el mayor desarrollo y variedad de los taxones arbóreos, entre los que hay tanto taxa mediterráneos (Olea-Phillyrea, Quercus ilex tp. y Buxus) como caducifolios, que salvo los quejigos y avellanos (10-15\%) no superan el $3 \%$ (Ulmus, Salix, Viburnum, Fraxinus). Nuevamente la deficiente conservación esporopolínica limita los resultados obtenidos y, del nivel arqueológico paralelizable al del Cabezo de la Cruz, únicamente se dispone de la información de una muestra. En ella, las coníferas predominan en el paisaje mientras que descienden el avellano y ambos tipos de Quercus. El boj llegará a superar el $10 \%$, indicando un mayor desarrollo del matorral. Este registro, según la autora, podría corresponder al inicio de un periodo de mayor mediterraneidad y/o aridez que parece caracterizar a la segunda mitad del Holoceno en la Península Ibérica (González-Sampériz 2004a).

El valle del río Matarraña (términos municipales de Mazaleón y Maella, Teruel) es donde se ubican los tres depósitos arqueológicos. La ocupación humana de carácter alternante del abrigo de El Pontet (Montes et al. 2006) comienza en el Mesolítico macrolítico (niveles i y g), al que suceden un nivel mesolítico con geométricos datado en $7340 \pm 70$ BP (nivel e) y otro adscrito al Mesolítico geométrico-Neolítico (nivel c inf.: $6370 \pm 70 \mathrm{BP}$ ). En la parte superior de este nivel, hay una ocupación clara del Neolítico cardial 
(c. sup.), finalizando la secuencia en el Neolítico reciente (nivel b: $5450 \pm 290 \mathrm{BP}$ ). La esterilidad polínica de los niveles mesolíticos motiva que el registro polínico más antiguo sea el de una muestra del nivel e (VIII milenio BP). Este es el de menor diversidad taxonómica de la secuencia ya que en la cubierta arbórea-arbustiva junto al dominante pino (>60\%), aparecen Quercus ilex-coccifera tp. y Fraxinus con valores inferiores al $5 \%$, y Helianthemum tp. superando esta cifra, mientras que en el estrato herbáceo solo aparecen compuestas y artemisias. Esta situación varía en las dos muestras del nivel estéril que sucede a esta ocupación, al aumentar la diversidad taxonómica y retroceder la cubierta arbórea (López García 1992; López García y López Sáez 2000).

La secuencia estratigráfica del abrigo de Els Secans también refleja el periodo de transición del Mesolítico geométrico al Neolítico. De los tres niveles de este yacimiento, los niveles IIb (Mesolítico geométrico) y IIa (Neolítico antiguo) son los correspondientes a estos periodos de ocupación (Rodanés et al. 1996). En el estudio palinológico hay dos hiatos polínicos que afectan a la secuencia (López García 1994; López García y López Sáez 1996). La muestra más antigua es la de menor representación arbórea $(<35 \%)$ y en ella, al igual que en el depósito anterior, ya se pone de manifiesto el constante dominio del pino a lo largo de toda la secuencia polínica. Posteriormente, en los registros polínicos asociados al nivel II, el polen arbóreo aumenta considerablemente (80 \%), destacando los valores de Buxus y Daphne (5-10\%). Tras el hiato polínico, se observa un ligero retroceso de la cubierta arbórea, aunque Quercus ilexcoccifera tp. aumenta con respecto a los niveles precedentes. La autora del estudio, P. López García, sitúa este espectro polínico holoceno (cubierta arbórea dominada por el pino, acompañado de especies propias del área mediterránea, y de taxones como Salix, Populus, Alnus y Corylus asociados a la vegetación de ribera) en el período Atlántico.

Al igual que en los dos depósitos precedentes, en el abrigo de Botiquería dels Moros (Barandiarán 1976, 1978; Barandiarán y Cava 2000) hubo diversas ocupaciones epipaleolíticas y neolíticas de carácter temporal con niveles de abandono entre ellas: Mesolítico geométrico (nivel 2: $7600 \pm 59$ BP y $7550 \pm 200$ BP); transición Mesolítico-Neolítico (nivel 4: $6830 \pm 50 \mathrm{BP}$ ) y Neolítico antiguo cardial (nivel 6: $6040 \pm 50 \mathrm{BP}$ y nivel 8: 6240 $\pm 50 \mathrm{BP}$ ). La esterilidad polínica del nivel más antiguo (nivel 2) reduce la información palinológica al VII mile- nio BP. La dinámica vegetal en este milenio mantiene las mismas características comentadas anteriormente: dominio de la cubierta arbórea y del pino dentro de ella; oleáceas, enebros, Quercus ilex-coccifera tp. y avellano les acompañan aunque con valores más reducidos; predominio de las compuestas (Asteraceae) en el estrato herbáceo y constancia de antropización del paisaje y de actividades agrícolas durante la ocupación neolítica (López Sáez et al. 1991; López García 1992).

Siguiendo en territorio turolense y más concretamente en la margen izquierda del río Martín, disponemos de otro registro polínico en el abrigo de Los Baños (Ariño). Este yacimiento fue ocupado de un modo intermitente durante el VIII milenio (Utrilla y Rodanés 2004): Mesolítico macrolítico (niveles 1b y 2b1: $8040 \pm 50$; $7840 \pm 1000 ; 7740 \pm 50)$; Mesolítico geométrico niveles 2b3: $7570 \pm 100$, 2b3 inf.: $7550 \pm 50$ y 2b3sup: $7530 \pm 50$ ); Mesolítico? (nivel 2d). En él se recogieron dos columnas polínicas, aunque una contaminación entomófila (nidos de avispas) del sedimento invalida a la columna del corte $1 \mathrm{~A} / 3 \mathrm{~A}$. En la segunda columna (corte 1A/A'), los problemas de conservación esporopolínica reducen los resultados al nivel $2 \mathrm{~b} 3$. El registro polínico muestra la existencia de un paisaje típico mediterráneo (codominancia de Pinus, Juniperus y Quercus ilex-coccifera tp., acompañados de elementos mesotermófilos). Resulta llamativa la escasa presencia de taxones característicos de la vegetación de ribera, teniendo en cuenta la proximidad del río Martín (González-Sampériz 2004b).

La primera evidencia común a todos los yacimientos mencionados es el problema de la conservación esporopolínica. En todos ellos, en un menor o mayor grado, los niveles mesolíticos están afectados, reduciéndose nuestro conocimiento a visiones puntuales que no permiten establecer patrones evolutivos continuos.

En las secuencias turolenses, durante el VIII milenio BP, la composición de las comunidades vegetales mantiene el predominio de especies propias de un ambiente de tipo mediterráneo. Dentro de la cubierta arbórea el pino (Pinus halepensis tp.) tiene una mayor representación, siendo sus principales acompañantes Quercus ilex-coccifera tp. y/o Juniperus (en el caso de Los Baños, estos tres taxones mantienen una mayor paridad en sus valores). La presencia de especies caducifolias como el avellano o el olmo indican la disponibi- 


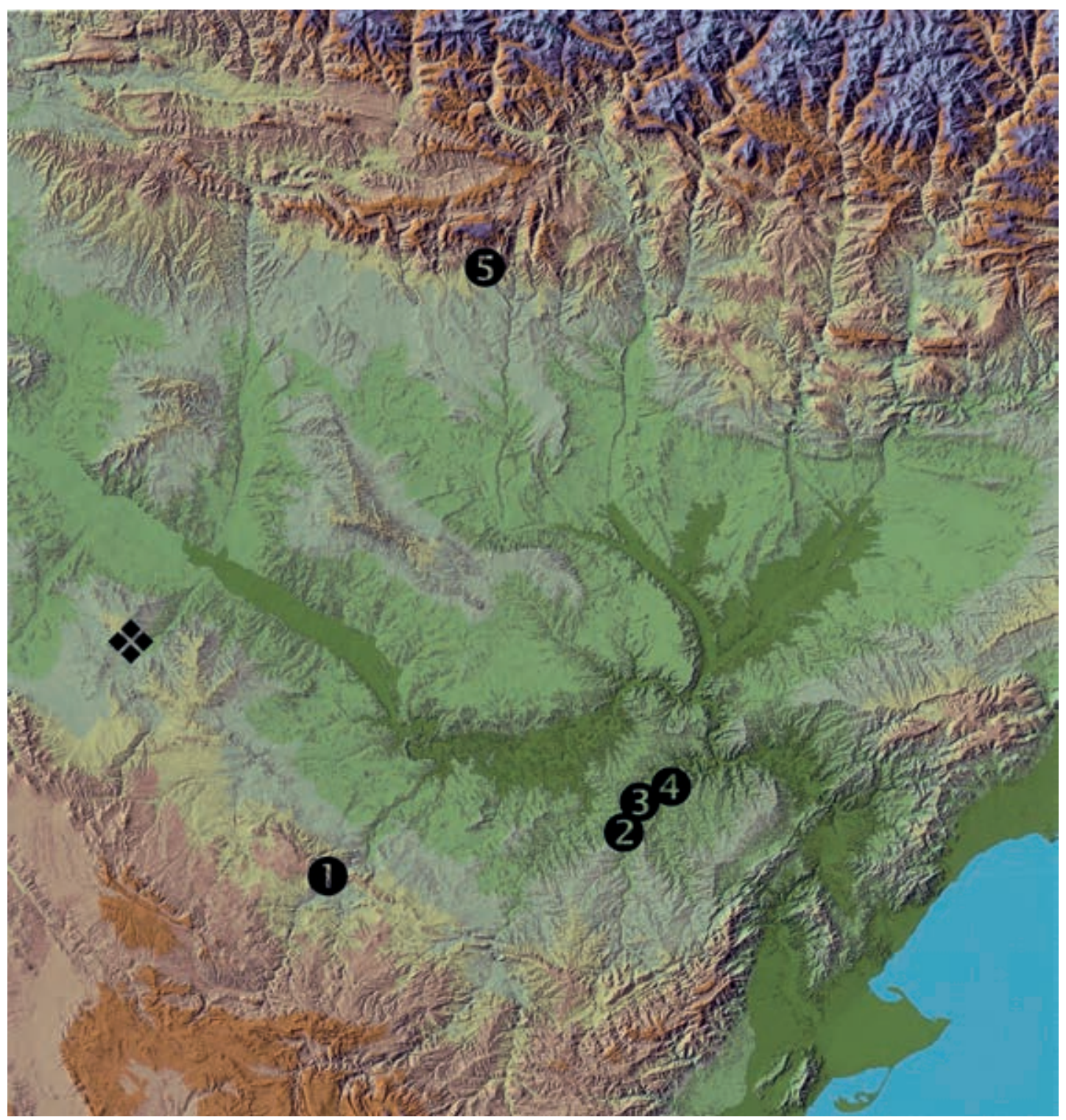

Figura 7. Situación del Cabezo de la Cruz y los yacimientos con análisis polínicos mencionados en el texto: 1. Los Baños, 2. Botiquería dels Moros, 3. Secans, 4. El Pontet, 5. Cueva de Chaves, 6. Peña 14.

lidad de cierto grado de humedad edáfica, lógicamente asociada a zonas relativamente próximas a los cursos de agua. Entre las especies del bosque de ribera, el aliso y el sauce están presentes pero nunca formando masas forestales de importancia. Las juncáceas, ciperáceas y helechos ocupan también este nicho ecológico. Frente a estas zonas de una mayor disponibilidad hídrica en el subsuelo, están aquellas en las que la aridez potenciaba la ubicación de especies de carácter estépico como Artemisia, Chenopodiaceae o Ephedra. Evidentemente, el registro de Peña 14 tiene ciertas diferencias con estas secuencias. Aunque los taxa medite- rráneos aumentan con respecto a niveles previos del Holoceno inicial (Olea-Phillyrea, Quercus ilex tp. Buxus), en este abrigo del prepirineo aragonés, los taxones caducifolios y/o marcescentes mantienen una mayor importancia en el paisaje y una mayor diversidad (quejigos, avellanos, olmos, fresnos). Aunque dado el tipo de depósito, me he centrado en los estudios paleopalinológicos procedentes de contextos arqueológicos, estos resultados son concordantes con los obtenidos en depósitos de origen no antrópico (Davis 1994) como el de Hoya del Castillo (CAS-3: 7325 65 BP) o la Laguna de Guállar (GUA-3: $7485 \pm 80$ BP). 
Pese a los condicionantes del registro polínico de los niveles mesolíticos del Cabezo de la Cruz, podemos confirmar que el paisaje vegetal de su entorno era de similares características a los anteriormente citados. Ha sido una pena no poder disponer de una seriación evolutiva del paisaje, ya que se han analizado niveles previos y posteriores a la ocupación humana, circunstancia que nos podía haber facilitado información sobre la afección humana del paisaje en estos periodos finales de los últimos cazadores-recolectores. En algunos de los yacimientos mencionados, aunque haya sido de un modo discontinuo, ha habido ocupación neolítica posterior. En estos niveles quedan evidenciados los procesos de antropización del paisaje asociados al nuevo sistema económico, incluso la existencia de prácticas agrícolas en el entorno (El Pontet). Sin embargo, la deficiente conservación esporopolínica de la mayoría de las muestras epipaleolíticas no permite establecer con claridad si durante el VIII milenio BP, y en un contexto de cazadores-recolectores, ya la interferencia del ser humano en su entorno era de tal magnitud que quedara reflejada en nuestros estudios. En el caso de Els Secans, la autora del estudio relaciona los altos valores de Asteraceae con la acción antrópica (López García y López Sáez 1996; López Sáez et al. 2006) y en Los Baños, no se puede asegurar que los incendios (antrópicos o no) sean la causa del paisaje relativamente abierto que existe en este periodo (González-Sampériz 2004b).

\section{BIBLIOGRAFÍA}

Alcalde, G., Borrell, F., Casellas, S., Molist, M., Oliva, M., Saña, M. y Vicente, O. 2001-2002: «La Prunera, un assentament del neolític final a l'aire lliure a la zona dels Prepirineus catalans». Tribuna de Arqueología 2001-2002: 39-60.

BARANDIARÁN, I. 1976: «Botiquería dels Moros (Teruel). Primera fechación absoluta del complejo geométrico del Mesolítico mediterráneo español». Zephyrus, XXVI-XXVII: 183-186.

—, 1978: «El abrigo de la Botiquería dels Moros. Mazaleón (Teruel). Excavaciones arqueológicas de 1974». Cuadernos de Prehistoria y Arqueología castellonenense, 5: 49-138.

BARANDIARÁN, I. y CAVA, A. 2000: «A propósito de unas fechas del Bajo Aragón: reflexiones sobre el Mesolítico y el Neolítico en la cuenca del Ebro». SPAL, 9: 293-326.
BuRJACHS, F., LÓPEZ-SÁEZ, J.A. e IRIARTE, M.J. 2003: «Metodología arqueopalinológica». En Buxó, R. y Piqué, R. (dirs.): La recogida de muestras en arqueobotánica: objetivos y propuestas metodológicas, 11-18, Museo de Arqueología de Cataluña. Gerona.

CARrión, J.S. y NAVARRO, C. 2002: «Cryptogram spores and other non-pollen microfossils as sources of palaeoecological information: case-studies from Spain». Ann. Bot. Fennici, 39: 1-14.

Castroviejo, S., Laínz, M., López, G., MontSERRAT, P., MuÑOZ, F., PAIVA, J. y VILlar, L. (eds.) 1986: Flora ibérica. Plantas vasculares de la Península Ibérica e Islas Baleares (Lycopodiaceae/Papaveraceae). I, 573 p.

- (eds.) 1990: Flora ibérica. Plantas vasculares de la Península Ibérica e Islas Baleares (Platanaceae/Plumbaginaceae). II, 897 p.

CHristopher, R.A. 1976: «Morphology and taxonomic status of Pseudoschizaea Thiegart and Frantz ex R. Potonié emend». Micropaleontology, 22 (2): 143-150.

DAVIS, B. 1994: Palaeolimnology and Holocene environmental change from endorreic lakes in the Ebro Basin, North-East Spain. Tesis doctoral inédita. University of Newcastle, 317 p.

GÓNZALEZ SAMPÉRIZ, P. 2004: Evolución paleoambiental del sector central de la cuenca del Ebro durante el Pleistoceno superior y Holoceno. Instituto Pirenaico de Ecología. CSIC, 210 p. Zaragoza.

—, 2004b: «Análisis polínico del abrigo de los Baños». En Utrilla, P. y Rodanés, J.M.: Un asentamiento mesolítico en el valle del río Martín. El abrigo de Los Baños (Ariño, Teruel). Monografías Arqueológicas, 39: 59-62. Universidad de Zaragoza.

GRENFELL, H.R. 1995: «Probable fossil Zygnematacean algae spore genera». Palaeobotany and Palynology, 84: 201-220.

IRIARTE, M.J. 1994: El paisaje vegetal de la Prehistoria reciente en el Alto valle del Ebro y sus estribaciones atlánticas: datos polínicos, antropización del paisaje y primeros estadios de la economía productora. Tesis doctoral, 393 p. Facultad de Geografía e Historia de la Universidad del País Vasco. Vitoria-Gasteiz.

—, 2009: «Los inicios del Holoceno reciente en el valle del río Huerva: la secuencia palinológica protohistórica del yacimiento arqueológico de $\mathrm{Ca}$ - 
bezo de la Cruz (La Muela, Zaragoza)». En Picazo, J.V. y Rodanés, J.M. (eds.): Los poblados del Bronce final y la Primera Edad del Hierro. Cabezo de la Cruz (La Muela, Zaragoza. Gobierno de Aragón, 108-131.

LÓPEZ GARCÍA, P. 1992: «Análisis polínicos de cuatro yacimientos arqueológicos situados en el Bajo Aragón». Aragón/Litoral Mediterráneo. Intercambios culturales durante la Prehistoria. Institución Fernando el Católico. Zaragoza, 235-242.

LóPez García, P. y LóPez SÁEZ, J.A. 1996: «Análisis paleopalinológico del yacimiento de El Secans: dinámica de la vegetación durante el Cuaternario». En Rodanés, J.M., Tilo, M.A. y Ramón, N. (coords.): El abrigo de Els Secans (Mazaleón, Teruel). La ocupación del valle del Matarraña durante el Mesolítico y Neolítico antiguo. AlQannis, 6: 84-95.

-, 2000: «Le paysage et la phase épipaléolithique-mésolithique dans les Pre-Pyrénées aragonaises et le bassin moyen de l'Ebre à partir de l'analyse palynologique». En Les derniers chasseurs-cueilleurs d'Europe occidentale (13 000-55 000 av. J. C.). Actes du colloque international de Besançon, Annales Littéraires, 699: 59-69.

LÓPEZ GARCÍA, P., LÓPEZ SÁEZ, J.A. y SÁNCHEZ, J.J. 1991: «Análisis polínico del yacimiento de Botiquería (Mazaleón, Teruel)». Trabajos de Prehistoria, 48: 395-403.

López SÁEz, J.A., LÓPEZ GARCÍA, P. y LÓPEZ MERINO, L. 2006: «La transición mesolíticoneolítico en el valle medio del Ebro y en el Prepirineo aragonés desde una perspectiva paleoambiental: dinámica de la antropización y origen de la agricultura». Revista Iberoamericana de Historia, 1: 4-11.

MedeAnic, S., ZAMORA, N. y CORRÊA, I.C.S. 2008: «Non-pollen palynomorphs as environmental indicators in the surface samples from mangroves in southern Costa Rica». Revista Geológica de América Central, 39: 27-51.

MonTES, L. 2001-2002: «El abrigo mesolítico de Peña 14 (Biel, Zaragoza). Excavaciones 1999 y 2000». Salduie, 2: 291-306.

Montes, L., Utrilla, P. y Mazo, C. 2006: «El Mesolítico macrolítico en Aragón en el contexto del valle del Ebro y la Cataluña costera». En Alday, A. (coord.): El Mesolítico. Cuenca del Ebro y litoral mediterráneo. Diputación Foral de Álava. Vitoria-Gasteiz, 193-222.
Pantaleón-Cano, J., Yll, E., Pérez-Obiol, R. y Roure, J.M. 2003: «Palynological evidence for vegetational history in semi-arid areas of the western Mediterranean (Almería, Spain)». The Holocene, 13 (1): 109-119.

PiCAZO, J.V. y RodAnÉs, J.M. (eds.) 2009: Los poblados del Bronce final y Primera Edad del Hierro. Cabezo de la Cruz. La Muela, Zaragoza. Gobierno de Aragón. 498 p. Zaragoza.

ReILle, M. 1990: Leçons de Palynologie et d'analyse pollinique. CNRS. 206 p. París.

RodAnÉS, J.M., TILO, M.A. y RAMÓN, N. 1996: «El abrigo de Els Secans (Mazaleón, Teruel). La ocupación del valle del Matarraña durante el Mesolítico y Neolítico antiguo». Al-Qannis, 6, 106.

Rossignol, M. 1962: «Analyse pollinique de sédiments marinus quaternaires en Israel II: sédiments pleistocènes». Pollen et Spores, III (2): 121-145.

SCOTT, L. 1992: «Environmental implications and origin pf microscopic Pseuoschizaea Thiegart and Frantz ex. R., Potonié emend. in sediments». Journal of Biogeography, 19: 349-354.

TAKAHASHI, K. 1979: «Pseudoschtzaea from the Pleistocene sediments in the Ariake Sea area». West Kyushu, 長崎大学教養部紀要. 自然科学, 19: 39-49.

THIERGART, F. y FrANTZ, U. 1962: «Some spores and pollen grains from a Tertiary brown coal deposit in Kashmir». The Palaeobotanist, 10 (1/2): 84-86.

Tutin, T.G., Heywood, V.H., Burges, N.A., MoOre, D.M., VAlentine, D.H., WAlters, S.M. y WeBB, D.A. (eds.) 1980: Flora Europaea. Vol. 5.

UTRILlA, P. y RODANÉS, J.M. 2004: Un asentamiento mesolítico en el valle del río Martín. El abrigo de Los Baños (Ariño, Teruel). Monografías Arqueológicas, 39: 113. Universidad de Zaragoza.

WOLFF, H. 1934: «Mikrofossilien des pliozänen Humodils der Grube Freigericht bei Dettingen a. M. und Vergleich mit älteren Schichten des Tertiärs sowie posttertiären Ablagerungen». Arb. InstPalaeobot. Petrogr. Brennst, 5: 55-101.

Yll, R., Carrión, J.S., Pantaleón, J., Dupré, M., LA RocA, N., Roure, J.M. y PÉREZ-Obiol, R. 2003: «Palinología del Cuaternario reciente en la Laguna de Villena (Alicante, España)». Anales de Biología, 25: 65-72. 


\section{El campamento del Cabezo de la Cruz en el contexto cronológico y cultural de la margen derecha del valle medio del Ebro}

\subsection{INDUSTRIA LÍTICA}

\subsubsection{TiPOLOGÍA Y EVOLUCIÓN DE LOS COMPLEJOS INDUSTRIALES}

La intensidad de las investigaciones actuales sobre yacimientos con niveles epipaleolíticos/ mesolíticos en el valle del Ebro permite afirmar que se ha convertido en una de las zonas mejor conocidas de la Península Ibérica. Los trabajos de I. Barandiarán en el Bajo Aragón en los años setenta de pasado siglo, concretamente en los abrigos de Botiquería dels Moros y Costalena, la publicación de sus memorias y numerosos artículos en solitario o en colaboración con A. Cava (Barandiarán 2009, 24 y ss.) y los trabajos posteriores en gran parte de la Cuenca del Ebro nos permiten contar con un claro esquema de la evolución de la industria lítica y, en ocasiones, con un adecuado marco cronológico de referencia (Utrilla y Montes 2009).

Para la contextualización del yacimiento que estudiamos queremos dejar claras tres premisas:

- El tratamiento de la información de zonas extensas como el valle del Ebro tiene evidentes ventajas al proporcionar visiones amplias y, en algunos casos, permite identificar procesos similares, pero no es menos cierto que, cuando la información no es homogénea y completa, a la vez que esta aumenta, aumenta «el ruido», por lo que se pueden producir distorsiones que no tienen cabida, o son menores, cuando la escala es más pequeña.

- Así, en el estudio comparativo nos limitaremos, en principio, a los yacimientos aragoneses de la margen derecha del Ebro. Para una visión más amplia recurriremos a las conclusiones de otros estudios generales recientemente desarrollados tanto del valle del Ebro como de otras regiones (Utrilla y Montes 2009).
- Igualmente, prescindiremos de las etapas más antiguas: del actualmente denominado Epipaleolítico y del Mesolítico de muescas y denticulados bien tratados en recientes síntesis (Cava 2004; Alday 2006) y que no afectan al devenir del campamento del Cabezo de la Cruz por ser complejos cronológicamente anteriores.

Teniendo en cuenta estos presupuestos, para la zona que queremos tratar existen varios esquemas con evidentes similitudes. Recogemos los más recientes y significativos, a nuestro juicio, ya que en ellos se refleja el pensamiento y la asimilación de propuestas propias anteriores, teniendo en cuenta que, a la hora de establecer comparaciones, en la mayoría se hace referencia a yacimientos del Alto Ebro o de su margen izquierda.

Destacaremos, en primer lugar, que los primeros esquemas parten de las excavaciones del Bajo Aragón. A la publicación de Botiquería dels Moros y su datación absoluta (Barandiarán 1976, 1978) le siguen una serie de estudios sobre Costalena y la interestratificación entre ambos. Es el caso de los trabajos del congreso sobre industrias líticas en el Bajo Aragón (Barandiarán y Cava 1985) o el dedicado a la relación de Aragón con el litoral mediterráneo (Barandiarán y Cava 1992), la memoria de Costalena (Barandiarán y Cava 1981a, 1989) o las últimas dataciones absolutas de ambos yacimientos (Barandiarán y Cava 2002). Estos trabajos, unidos a las conclusiones de la tesis doctoral de A. Cava, forjaron el esquema evolutivo de estas industrias (Cava 1986, 1987, 1994). A ello han contribuido, igualmente, la excavación de Los Baños de Ariño (Utrilla y Rodanés 2004) y, en menor medida, la memoria de Secans (Rodanés, Tilo y Ramón 1996) y los avances de la excavación de Pontet (Mazo y Montes 1992) y Abrigo de Ángel (Utrilla y Domingo 2002; Utrilla, Domingo y Martínez Bea 2003; Domingo, 
Bea y Utrilla 2010), amén de diferentes síntesis y visiones generales (Utrilla 1997, 2001, 2002; Utrilla et al. 1998).

Elegimos el esquema planteado en el ensayo de Cava (1994) porque supone, a nuestro entender, la primera visión global y de referencia sobre el Mesolítico en el valle del Ebro y, aunque sobrepasa - como la mayoría - los límites geográficos que nos hemos marcado, parte de los trabajos antes mencionados y reúne buena parte de las premisas y conclusiones que en ellos se exponen. A las primeras manifestaciones industriales del Holoceno le suceden los conjuntos de la:

Fase 2. Geometrización del Mesolítico pleno. Máxima representación de tipos trapeciales y menor de triángulos. Técnica de microburil. Finales del IX milenio BP e inicios del VIII. Niveles 2 de Botiquería, e de Pontet parte de c3 de Costalena, 8 medio y superior de Ángel.

Fase 3. Evolución final del Mesolítico. Sustitución paulatina de los trapecios por triángulos. Se sigue utilizando la técnica del microburil. Se identifican diferentes modelos tipológicos según áreas geográficas. En la mitad oriental se sigue un modelo similar al del Mediterráneo (cocina) con aparición de triángulos de espina central (tipo cocina) antes de la aparición de la cerámica, mientras que en la parte occidental el modelo tiene una mayor relación con los Pirineos. La fase se podría situar dentro del VII milenio BP. Botiquería 4, Pontet c inferior, Secans II, Costalena transición $\mathrm{C} 3 / \mathrm{c} 2$.

Fase 4. Incidencia del proceso neolitizador. En el Bajo Aragón triángulos y segmentos con retoque en doble bisel con presencia de cerámica.

La datacións absoluta de varios niveles de Botiquería y Costalena es el argumento para una nueva revisión sobre el Bajo Aragón. La publicación de Barandiarán y Cava (2002), al igual que sucede en el caso anterior, va más allá del tratamiento de la mera evolución tipológico-cronológica de las industrias y niveles de ambos yacimientos y plantea un estado actual crítico de las investigaciones de los conjuntos del Bajo Aragón en el contexto del valle del Ebro. Nuestro interés, por motivos obvios, se centra en la:

Fase B. Introducción masiva de geométricos. Son preferentes los trapecios de retoque abrupto fabricados con técnica de microburil. Niveles 2 de Botiquería, la mayor parte de c3 de Cos- talena, e de Pontet, 2 de Los Baños de Ariño y 8 medio y superior de Ángel.

Fase C. Mesolítico final en su transición hacia el Neolítico. Niveles 4 de Botiquería, c inferior de Pontet, IIb de Secans y parte superior de Costalena. Progresiva sustitución de trapecios por triángulos. Aparecen en varios asentamientos triángulos tipo cocina, fase II, pero también aparecen los primeros elementos «indicadores» del Neolítico: cerámicas y retoque en doble bisel junto a algún taladro.

Fase D. Industria de triángulos y segmentos con retoque en doble bisel y progresiva desaparición de la técnica de microburil. Cerámica con variedad decorativa. Tipológicamente se puede considerar Neolítico a pesar de que económicamente no se detecten argumentos. Niveles 6 y 8 de Botiquería, c2 y c1 de Costalena, c superior de Pontet.

En las conclusiones de la memoria de excavaciones en el Abrigo de Los Baños de Ariño (Utrilla y Rodanés 2004) se propone un esquema, con cronologías absolutas, desde comienzos del Holoceno. El margen temporal que estamos tratando coincide con una evolución desde la fase 5.

Fase 5. Fase geométrica de trapecios (7700-7200 BP). Dominada por la incorporación masiva de trapecios de retoque abrupto, estaría representada en el Bajo Aragón por el nivel 2 de Botiquería $(7600 \pm 50 \mathrm{BP})$; nivel e de Pontet $(7340 \pm 70 \mathrm{BP})$, nivel $2 \mathrm{~b} 3$ inf. $(7550 \pm 50 \mathrm{y}$ $7570 \pm 100 \mathrm{BP})$ y 2 b3 sup. $(7350 \pm 60 \mathrm{BP}) \mathrm{de}$ Los Baños; 8b inf. y 8c de Ángel 1 (exc., Utri1la), contextos 8, 28, 39, y 45 de Sebastián y 2. ${ }^{\mathrm{a}}$ de Ángel 2.

Fase 6. Fase geométrica de triángulos (7200$6800 \mathrm{BP}$ ), con equilibrio o dominio de los triángulos sobre los trapecios, en algunos lugares de tipo cocina. En el Bajo Aragón este momento estaría representado por el nivel 4 de Botiquería $(6830 \pm 50 \mathrm{BP}$ y $6600 \pm 50 \mathrm{BP})$, con masivo dominio de los triángulos de retoque abrupto (con dos triángulos de doble bisel) y todavía sin cerámica; el nivel IIb de Secans con predominio de los triángulos tipo cocina (aunque incluye un triángulo de doble bisel), también sin cerámica y al que podría asignarse una fecha similar a la de Botiquería 4.

Fase 7. Fase de transición con la aparición de los primeros elementos neolíticos. Dominio de triángulos sobre trapecios pero aparecen 
dos nuevos elementos: retoque en doble bisel (que en la fase anterior aparecía tímidamente y quizá por intrusión); ahora se generaliza hasta equipararse al retoque abrupto y se documentan las primeras aportaciones cerámicas. Incisas como c3 inf. de Pontet (6370 70 BP) o simplemente lisas y de aplicaciones plásticas como Secans IIa, Costalena C2 y Botiquería 6 y 8 .

La última y reciente síntesis coincide con la reunión en Jaca dedicada al Mesolítico Geométrico en la Península Ibérica. Coordina y encabeza la publicación P. Utrilla y se introducen matices y novedades sobre esquemas y ensayos anteriores (Utrilla et al. 2009):

A) Fase geométrica de trapecios (7900-7300 BP). Incorporación masiva de trapecios de retoque abrupto. Nivel 2 de Botiquería; e de Pontet, base de c3 de Costalena, 2b1 y 2 b3 inf y 2b3 sup de Los Baños; 8c de Ángel 1. Podría comenzar su evolución con la aparición de tipos anchos achaparrados en la base de los niveles y evolucionar a los tipos alargados en la parte superior, fenómeno documentado por el momento en Los Baños y Botiquería.

B) Fase geométrica de triángulos (7300-6800 BP) con equilibrio o dominio de estos sobre los trapecios. Niveles II y IV de Forcas II; III sup + II inf de Kampanoste Goikoa; bloque II de Aizpea. Aparecen tipos ultrapirenaicos (triángulos escalenos con retoque inverso en la base, triángulos de base pequeña retocada). A partir de la evolución en Forcas que aparecen en el nivel IV pero no en el II se sugiere que esta penetración se produce en un momento avanzado, en torno al 7000 BP.

C) Fase de transición con aparición de los triángulos de tipo cocina y de los primeros elementos neolíticos (6750-6300 BP). Dominio de triángulos sobre trapecios pero con aparición de retoque en doble bisel y en algunos yacimientos primeras cerámicas. Secans IIb, Botiquería 4, parte alta de Costalena c 3, C inferior de Pontet o 2 de Ángel 2 en el Guadalope.

D) Fase de generalización de los elementos «neolitizadores», cerámicas y retoque en doble bisel, marca este recorrido en el Bajo Aragón aunque en el seno de una economía todavía epipaleolítica. Costalena $\mathrm{C} 2$ y C1; Botiquería 6 y 8; Pontet c superior; Plano del Pulido en Caspe, niveles cg y cg2.
Consideraciones sobre los esquemas:

- Existen tres factores que se han utilizado para su elaboración y que, si bien ayudan a la comprensión global, han provocado distorsiones: los niveles arqueológicos con sus correspondientes artefactos, la datación absoluta de los mismos y las diferentes zonas y territorios que engloban un espacio amplio con dinámicas de ocupación y ecosistemas diferentes y con desigual intensidad en la investigación.

- A pesar de lo anteriormente comentado, existe una evolución industrial del complejo geométrico clara, reflejada en todos los esquemas y que salvo escasos matices apenas ha variado desde las primeras síntesis y que parece, a tenor de los datos, incuestionable: inicio del complejo geométrico con predominio de trapecios de retoque abrupto, progresiva sustitución por armaduras triangulares igualmente de retoque abrupto, en algunos casos tipo cocina, aparición del retoque en doble bisel en tipos triangulares y/o segmentiformes, introducción, en algunos casos paralela a estos últimos, de las primeras manifestaciones alfareras.

- Esta clara evolución no está inequívocamente representada en todos los niveles y yacimientos tratados. Es decir, como podemos suponer y como es de esperar, cada una de estas fases tipológicas arriba señaladas no coincide con niveles arqueológicos igualmente claros y definidos lo que provoca lógicos «desajustes» entre los esquemas.

- Lo mismo podríamos decir de las dataciones absolutas. Sin entrar en un análisis detallado del repertorio, a nadie se le escapa que, además de los problemas inherentes a las dataciones absolutas en general y a la cantidad, calidad y tipo de muestra: como tipo de desviaciones, muestras de vida larga o corta, datación de una sola muestra o recogida en un mismo nivel de diferentes muestras para una sola datación, discrepancias entre laboratorios, análisis convencionales o AMS..., lo cierto es que, en el importante repertorio del Mesolítico del valle del Ebro, muchas de estas situaciones se producen por lo que tampoco esa evolución industrial, como es lógico, la podemos aquilatar en el tiempo y en el espacio de una forma pautada como si se tratase de acontecimientos históricos puntuales.

- Todos estos factores han influido y han mediatizado en gran parte los esquemas antes 
señalados y han provocado ligeras discrepancias o matices entre los mismos, según se le haya dado más importancia o peso a uno $\mathrm{u}$ otro factor, a pesar de que en todos los casos la intención ha sido, como no podía ser de otra manera, conjugar industria, nivel y datación.

- Queremos señalar un factor espacial importante que destaca matices, ya señalados, pero que conviene tener presente. La vertiente sur de la cuenca del Ebro en la que incluimos tanto el Maestrazgo como el Bajo Aragón tiene un comportamiento similar al Mediterráneo o, lo que viene a ser lo mismo en estos momentos, las afinidades con la evolución de lo que se ha venido en denominar Grupo Cocina. Esto se ve claramente en el inicio de la evolución del geometrismo de formas triangulares con la aparición de los tipos cocina. En la vertiente norte y Alto Ebro las afinidades en estos momentos con formas derivadas de complejos ultrapirenaicos están igualmente documentadas. Ello no es obstáculo para que existan contactos o interrelaciones entre ambos territorios como se aprecia en diferentes materiales y en la presencia, sobre todo, de elementos de tradición cocina en contextos más septentrionales y occidentales. El caso contrario es más difícil de detectar. Los elementos pirenaicos no aparecen por el momento o no hemos podido confirmarlos con claridad al sur del Ebro.

- No tendríamos inconveniente teórico en admitir una fase específica de triángulos, paralela a la fase Mesolítico tipo B del País Valenciano (Martí et al. 2009, 251), anterior a la fase de transición al Neolítico con presencia de los primeros elementos del complejo neolítico, incluso en un reciente esquema así lo hemos planteado (Rodanés y Picazo 2005). No obstante, hay que reconocer que, por desgracia y como señalábamos con anterioridad, los niveles no son tan claros al respecto y existen sólidos argumentos para mantener otras posiciones, es decir, que existen en los mismos estratos presencia de materiales de distintas tradiciones. Así se explicarían las sutiles variaciones o diferencias entre los esquemas de Cava (1994) y Barandiarán y Cava (2002). Diferente, como comentaremos más adelante, son las variaciones en las otras ordenaciones reseñadas (Utrilla y Rodanés 2004; Utrilla et al. 2009) cuya diferencia fundamental estriba en la introducción de factores medioambientales y territoriales en la última, que propician la modificación del esquema, definiendo dos fases de triángulos: la más antigua representada esencialmente en Forcas y Alto Ebro y la posterior con elementos de tipo cocina más centrada en yacimientos del Bajo Aragón donde no estaría representada la anterior.

- Nuevamente queremos incidir en el argumento de que la ecuación o equiparación nivel cultural, estrato, materiales y cronología no es tan clara como a priori sería deseable, si a esto añadimos factores territoriales y medioambientales el problema y la solución se vuelven más complicados Esto se aprecia claramente en los registros del valle del Matarraña que son complejos y que, a pesar de que la evolución tipológica es clara, varios de los elementos se solapan en la evolución cronoestratigráfica de los yacimientos excavados (Botiquería, Secans, Costalena y Pontet). Sus dinámicas estratigráficas no son idénticas.

La margen derecha del Ebro

- Aparece representada por las cuencas en las que han aparecido yacimientos: MatarrañaAlgás, Guadalope, Martín y Huerva.

- La más densamente investigada y con mayor número de yacimientos coincide con la cuenca más oriental. Huerva, Martín y Guadalope solo presentan un yacimiento por valle.

- Excepto Abrigo de Ángel en el Guadalope, que presenta por su situación unas características ecológicas similares a los conjuntos del Maestrazgo correspondientes a la Comunidad Valenciana - que se traduce en una evolución industrial similar-, el resto de los lugares comparten características comunes en su entorno y medio físico.

\section{Cuenca del Matarraña y Algás}

- Territorio pionero en las investigaciones y donde por primera vez y mejor se ha documentado el modelo planteado por Fortea del Complejo Cocina.

- Se han publicado tres memorias: Botiquería, Costalena y Secans; las dos primeras de mayor entidad con una completa secuencia. La última coincide con un momento más reducido de ocupación. A ello hay que añadir el avance de la interesante estratigrafía de Pontet, cuya memoria se está finalizando y las breves noticias de Serdá y Sol de la Piñera, amén de otros yacimientos catalogados menos significativos. 
- Las secuencias del valle del Matarraña han servido de base desde los años setenta del pasado siglo para todos los trabajos posteriores y siguen cumpliéndose en un alto porcentaje los esquemas que se plantearon en su momento, en especial los concernientes a la evolución industrial.

- Las estratigrafías abarcan desde los momentos finales del complejo macrolítico hasta los inicios del proceso de neolitización.

- Son varios los intentos de interestratificación de los niveles excavados y con ligeras discrepancias entre uno u otro, cubren el marco temporal arriba comentado.

- En nuestra opinión, la mejor representación visual de la evolución industrial la proporcionan los espectros de geométricos realizados con idéntica metodología para Botiquería, Costalena y Pontet (Barandiarán y Cava 1985; Mazo y Montes 1992; Utrilla et al. 1998). Aquí aparece claramente la evolución de trapecios de retoque abrupto, triángulos, en especial tipo cocina, y laminitas de dorso curvo, triángulos y segmentos con retoque en doble bisel y primeras cerámicas. Téngase en cuenta que estos gráficos están realizados atendiendo a las profundidades de aparición de los diferentes tipos por lo que su visión es muy clara. Otro problema es que cada tipo se haya podido aislar en un estrato concreto - hecho que no tiene por qué ser así- y más difícil todavía que cada nivel o cada tramo concreto se haya podido, además, datar de manera absoluta.

- Todo ello nos lleva a considerar que, tal como se ha expuesto recientemente y como se aprecia en el gráfico correspondiente a las dataciones del valle, es cierto que existe un vacío radiométrico (Utrilla et al. 2009, 174), pero este no tiene que corresponder con un vacío de poblamiento, sino que puede ser atribuido a causas relacionadas más con la posibilidad de toma de muestras que con la inexistencia de ocupaciones. Debemos tener en cuenta que no se han podido datar los tramos inferiores de Costalena C3 o los tramos de Secans 2b, igualmente desconocemos en profundidad la estratigrafía de Serdá y Sol de la Piñera y totalmente Cueva Ahumada. Además, como luego comentaremos más detenidamente, el carácter intermitente, estacional o no, de las ocupaciones cuya duración es difícil de determinar agudiza el problema de su datación/ ocupación y sus posibles interrelaciones.
Los ensayos de interestratificación entre los diferentes yacimientos se han hecho patentes en las publicaciones de los yacimientos excavados, en especial al intentar contextualizar cada uno de ellos (Barandiarán y Cava 1985, 1989; Mazo y Montes 1992; Rodanés, Tilo y Ramón 1996). A este respecto, son interesantes los resultados de los análisis de correspondencias realizados en la memoria de Secans, tanto de geométricos, piezas tipológicas, restos de talla e industria lítica y cerámica, ya que agrupa yacimientos de similares características, industriales y espaciales, por lo que el «ruido» a la hora de analizar los resultados es menor, dando como resultado una continuidad entre los niveles analizados de los diferentes yacimientos desde el Mesolítico antiguo hasta los inicios de la neolitización (Rodanés, Tilo y Ramón 1996, 49-53 y 70).

\section{Cuenca del Guadalope}

Contamos con la excavación de los Abrigos de Ángel 1 y Ángel 2 en Ladruñán. No incluiremos el Abrigo del Plano del Pulido ya que su estratigrafía carece de los niveles coincidentes con las etapas del Mesolítico geomético. Su estratigrafía presenta un bloque macrolítico al que, posteriormente, se le añaden los niveles del Neolítico y Edad del Bronce (Utrilla et al. 2009, 145).

Ángel 1, excavado durante 5 campañas por A. Sebastián y, posteriormente, por P. Utrilla, R. Domingo y M. Martínez Bea (Utrilla et al. 2009, 142), ofrece una estratigrafía con una base correspondiente al Mesolítico de tipo macrolítico (8 d), seguida de una ocupación (nivel 8 c, 8 b inf.) geométrica, culminando la estratigrafía (8 b sup. Y 8 a) un último establecimiento durante el Neolítico.

Ángel 2, a unos $100 \mathrm{~m}$ de distancia del anterior, presenta una ocupación similar al abrigo anterior: fase macrolítica (2b), fase geométrica (2 a 2) y un final en el Neolítico (2 a 1) (Domingo, Bea y Utrilla 2010).

A falta de la memoria definitiva, destacaremos que la estratigrafía y la secuencia son coherentes con los modelos del resto de los yacimientos del Bajo Aragón, pero con afinidades más acusadas con yacimientos de las serranías mediterráneas o con los yacimientos del Maestrazgo valenciano con ecosistemas similares, que en la actualidad son diferentes al de los emplazamientos de cotas inferiores y comarcas en las que la aridez actualmente es más marcada. 


\section{Cuenca del río Martín}

Contamos con la reciente secuencia de los $\mathrm{Ba}$ ños que completa las aparecidas en el Matarraña con las que presenta evidentes similitudes, en especial, con Botiquería dels Moros. Por dataciones y evolución de tipos podríamos afirmar que Botiquería sería la evolución lógica de Los Baños. Con este abrigo coincide en la alternancia de niveles de ocupación y abandono y por la presencia en la base de un tipo de trapecios anchos de retoque abrupto, «achaparrados». Completa, como se ha dicho, las fases más antiguas del Matarraña (Botiquería 2, Costalena d y tramos inferiores de c3, Pontet g-i y e) ya que en Los Baños no están presentes las fases más evolucionadas de triángulos y sobre todo los niveles que reflejarían el proceso de neolitización.

\section{Valle del Huerva}

En sus tramos finales se localiza el yacimiento del Cabezo de la Cruz que estudiamos en esta monografía. Se trata de los restos de un campamento al aire libre del que hemos podido individualizar una cabaña. Poco aporta a la secuencia o a la evolución de los complejos industriales. La muestra es muy escasa y no permite realizar comparaciones estadísticas. Como hemos visto, existe un predominio de formas trapeciales y laminitas de dorso, si es que se puede considerar como tal y significativa esta mayoría, dada la exigua representación y el contexto en el que aparece.

\subsubsection{MATERIAS PRIMAS}

El completo estudio de las materias primas (MP) del Cabezo de la Cruz es ilustrativo del sencillo modelo de gestión de estos recursos, similar en varios aspectos al detectado en yacimientos cercanos y de similar cronología y diagnóstico cultural.

Se ha documentado el uso prácticamente exclusivo de lo que se conoce como sílex de Botorrita, susceptible de ser recogido en forma de riñones y tablas en las mismas inmediaciones del Cabezo. Este sería el procedimiento más habitual de recogida de MP sin que se descarte, en ocasiones, un modelo mixto utilizando como fuente de aprovisionamiento lugares concretos localizados en ambas riberas del Huerva, conocidos por los habitantes del yacimiento, no muy alejados y donde la extracción de la roca es fácil y segura.

La presencia de materiales alóctonos es residual. Una única muestra da testimonio de su exis- tencia y el sílex no difiere esencialmente de los anteriores ya que su procedencia es igualmente lacustre, sin impurezas y de la misma factura.

En suma, la utilización del denominado sílex de Botorrita es prácticamente exclusiva, fácilmente localizable en la Plana de La Muela y Plana de Zaragoza y en todas las vales y glacis circundantes.

En el abrigo de Los Baños (Ariño), en la cuenca del río Martín (Utrilla y Rodanés 2004), el mayor porcentaje (57\%) corresponde a sílex cretácicos de zonas cercanas al yacimiento, entre 10 y $15 \mathrm{~km}$ donde se encontrarían afloramientos como el próximo barranco de Estacas o bien en el cercano término de Alacón. Más lejana sería la procedencia de los sílex evaporíticos que representan un 38,8\% y se localizan en los términos de Lécera, Sástago o Azaila. Supone la extensión de territorio de captación hasta los $30 \mathrm{~km}$ desde el yacimiento. Por último, queda un $2,9 \%$, no identificado y que puede corresponder a variedades terciarias cercanas al propio yacimiento, si bien hay que tener en cuenta que no se han detectado nódulos en posición secundaria al pie del yacimiento o en el cauce del río (Leorza 2004).

En el yacimiento de Secans, en el valle del Matarraña, se identificaron cinco variedades diferentes de MP localizadas en el yacimiento mediante aproximaciones macroscópicas y láminas delgadas. Se han localizado tres posibles áreas de procedencia. La confluencia de los ríos Pena, Tastavins y Matarraña, a unos 20/25 km de distancia del yacimiento, con sílex de procedencia miocena que aglutina a las variedades MP2, MP3, MP4 y MP5. Los podemos localizar en el mismo cauce en posición secundaria, en las proximidades del yacimiento.

Hacia el Noreste, en el valle del Algás, se podría situar una segunda zona de procedencia, de una variedad opalina mucho menor en porcentaje de aparición y que coincidiría con MP1. Su lugar de procedencia primario podría localizarse en los Puertos de Beceite.

Por último, al Noroeste del yacimiento, en los alrededores de Puig Moreno o en las estribaciones de la Formación Caspe, se situaría el posible lugar de procedencia del sílex de facies Garum de M4 y MP5 con características muy similares al sílex monegrino con buenas características para la elaboración de las últimas fases de la cadena operativa. Sería el área más alejada (Rodanés, Tilo y Ramón 1996, 66 y 67). 
En definitiva, se podría asumir que el mayor porcentaje procedería de las cuencas altas del Matarraña y Algás y que pudieran aparecer en posición secundaria en el cauce del río próximo al yacimiento y a los cercanos, igualmente, de Botiquería y Costalena (Barandiarán y Cava 2002, 302).

- En general, podemos afirmar que existen ciertas coincidencias entre los yacimientos enunciados ya que en todos los casos las materias primas tienen una procedencia no muy lejana; no obstante, vemos que dentro de esta tendencia común a la mayor parte de los asentamientos de la época existen peculiaridades entre los tres ejemplos comentados.

- La localización más específica, ya que se encuentra inmerso en un lugar con abundante materia prima, corresponde al Cabezo de la Cruz, lo que nos lleva a poder manejar la hipótesis de que este territorio sería especialmente propicio al asentamiento o a la visita frecuente de población durante esta época. Si lo añadimos en lugar estratégico junto al río podrán contemplarse las dos variables fundamentales para justificar la elección del lugar.

- La presencia en posición secundaria de nódulos en el cauce del río es característica del valle del Matarraña, lo que proporcionaría MP sin necesidad de desplazamientos lejanos. No obstante, el análisis de Secans muestra una mayor diversidad en la captación de los recursos, aunque el predomino corresponde al procedente de la cabecera de los ríos Matarraña y Algás.

- El caso de los Baños de Ariño es diferente ya que no existen nódulos en posición secundaria, lo que obliga a un desplazamiento habitual para el aprovisionamiento, a pesar de que las distancias no son muy grandes. Este pequeño detalle nos puede llevar a la conclusión de que quizás en este caso la elección del asentamiento viene determinada también por otros factores que, como se afirma en la memoria, posiblemente pudieran estar relacionados con la presencia de fuentes termales (Martínez Bea 2004, 77).

- Las actividades de talla están documentadas en el Cabezo y en todos los abrigos analizados, aunque no aparecen grandes nódulos, lo que nos hace suponer que la selección o el trabajo previo de preparación se producía en los mismos lugares de aprovisionamiento. La excepción, entre los analizados, sería Secans -y quizás en los restantes abrigos del Matarraña/ Algás, que comparten similares ubicaciones hecho fácilmente explicable ya que los nódulos en posición secundaria aparecen a pie del mismo yacimiento.

- Las fuentes cuantitativamente importantes están en un radio de acción cercano al yacimiento. No serían necesarios grandes desplazamientos para su aprovisionamiento, en el caso de que lo fuesen, las distancias medias y quizás máximas se sitúan entre los 10 y $30 \mathrm{~km}$, lo que supone un gran aprovechamiento de las variedades de sílex local. Esto permitiría afirmar que los desplazamientos a larga distancia para el aprovisionamiento de sílex no serían frecuentes ni específicos.

El comportamiento es también similar al descrito en el País Valenciano. Los yacimientos mejor documentados aluden a una procedencia de las MP no superior a los $5 \mathrm{~km}$, siendo el límite los $30 \mathrm{~km}$ de distancia. Estos márgenes están referidos básicamente a productos laminares o utensilios retocados (Martí et al. 2009, 231). Es representativo el caso de la Falguera donde el entorno inmediato, no superior a los $50 \mathrm{~m}$, aporta el mayor porcentaje de MP (García Puchol 2005; García Puchol y Aura 2006), al igual que sucedía con Cabezo de la Cruz o valle del Matarraña.

En definitiva, no existen, o mejor no se detectan por el momento, grandes rutas, redes de intercambio o afloramientos significativos que aglutinen la procedencia de las MP. Por el contrario, sí que se establecen ciertas gradaciones en cuanto a la distancia: las muy próximas a los yacimientos como el Cabezo de la Cruz, que se sitúa en plena zona de captación, y valle del Matarraña que en el mismo cauce del río aparecen los nódulos en posición secundaria que son aprovechados por los ocupantes de los diferentes abrigos; y las que podríamos denominar de carácter intermedio, con movimientos hasta las fuentes primarias (en torno a los $30 \mathrm{~km}$ ) pero que no suponen en ningún caso recorridos de grandes distancias.

Todo ello coincide con lo documentado en la mayoría de los yacimientos del Mesolítico europeo occidental: disminución de la distancia de aprovisionamiento. Son pocos los útiles fabricados con materias primas excepcionales (Ghesquière y Marchand 2010, 52 y 58). 


\subsection{ADORNOS: C.RUSTICA}

En el Mesolítico del valle del Ebro las conchas de moluscos marinos representan la práctica totalidad de la materia prima empleada para objetos de adorno. A la muestra de 116 piezas recopiladas en la síntesis de Álvarez Fernández (2006), procedentes de 17 yacimientos, habría que añadir las dos piezas aparecidas en el Cabezo de la Cruz (fig. 1). Como es habitual las perforaciones, en ambos casos irregulares, se han realizado por presión directa con ampliación posterior del diámetro.

La C.rustica alcanza el 64,2\% de las especies identificadas en yacimientos del valle del Ebro, teniendo en cuenta que en el estudio se incluyen los diferentes niveles epipaleolíticos y mesolíticos, incluyendo, por lo tanto, las fases laminares, macrolíticas y geométricas.

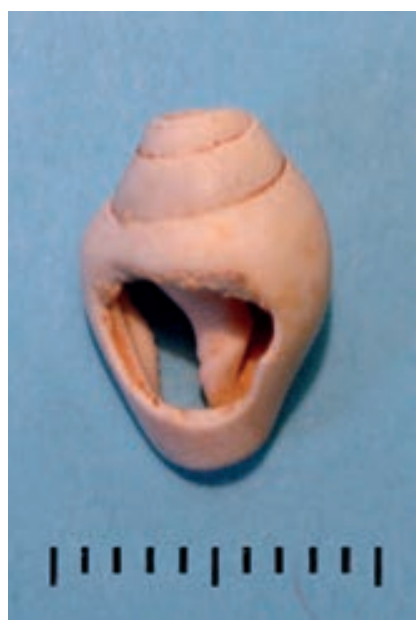

Con respecto a los yacimientos cercanos que nos pueden servir de referencia en la margen derecha del Ebro y con componente geométrico, podemos destacar que, excepto en Secans, en el resto de los yacimientos están presentes. En el Matarraña, en Botiquería, Costalena y Pontet, en el Martín en Los Baños y, en el Guadalope, en los abrigos de El Ángel 1 y 2. Reflejan inequívocamente las relaciones con el Mediterráneo y quizá sea el elemento que mejor nos señala las redes de intercambio a media y larga distancia, ya que aparecen ejemplares en el alto valle del Ebro y País Vasco (Alday y Cava 2009).

Figura 1. C. rustica.

\subsection{CRONOLOGÍA}

Las 14 dataciones proporcionadas por los yacimientos de las cuencas de los ríos Matarraña (Botiquería, Costalena y Pontet), Martín (Baños) y Huerva (Cabezo de la Cruz), muestran una dinámica de ocupación continua desde fechas alrededor del 8600 cal BP hasta el 7700-7600 cal BP (figs. 2-5). El epílogo final en torno al 7400-7200 cal BP probablemente es consecuencia de las dataciones poco precisas obtenidas para el nivel c 3 de Costalena, con unas elevadas desviaciones, y de la inclusión del nivel c inferior de El Pontet que ya incorpora elementos neolíticos como la cerámica. Así pues, el aparente vacío de dataciones alrededor del 7500 cal BP se debe a que nos encontramos ya en contextos neolíticos o con las primeras manifestaciones de materiales de la época, cuyas dataciones no se han incluido en la gráfica.

Las dataciones del Cabezo de la Cruz, con valores medios en torno a 7950 y 7800 cal BP representan, en cierto modo, la continuación de la secuencia de Los Baños y el momento inmediatamente anterior al nivel 4 de Botiquería. 


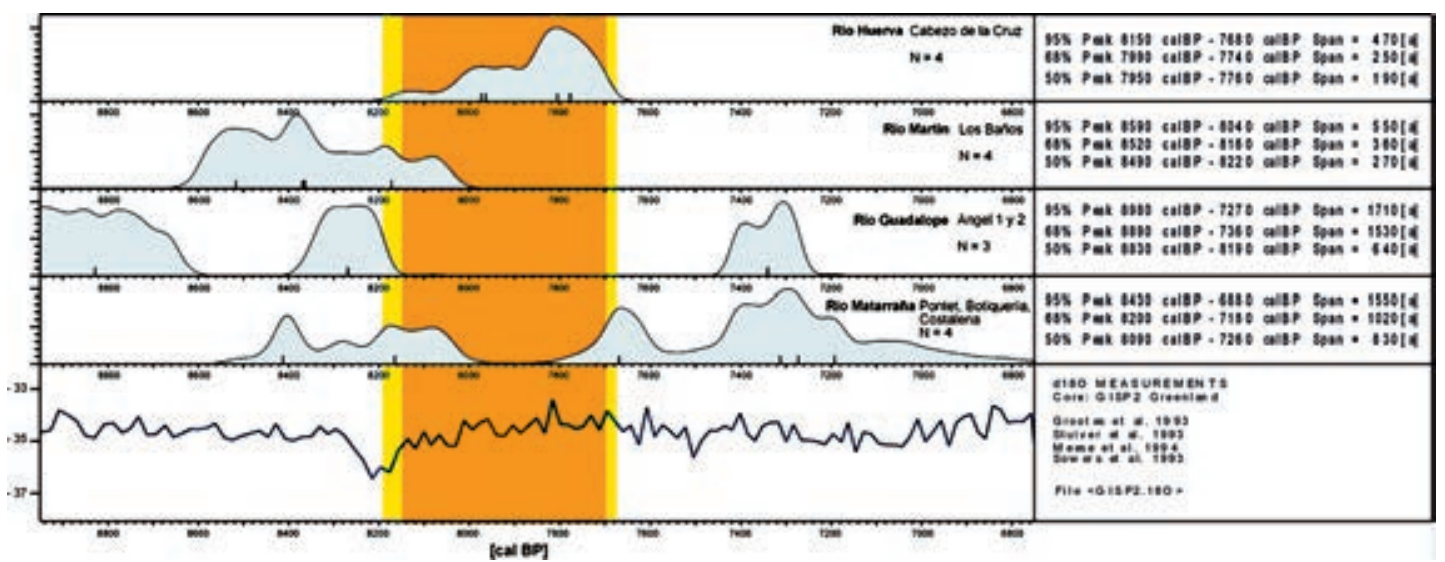

Figura 2. Dataciones calibradas del Cabezo de la Cruz, con relación a los yacimientos del Mesolítico geométrico situados en la margen derecha del río Ebro dentro del territorio aragonés. Se han agrupado por cuencas*. El tramo sombreado corresponde a los valores extremos de los intervalos asociados a 1 y 2 sigmas calculados** para las fechas del Cabezo de la Cruz.

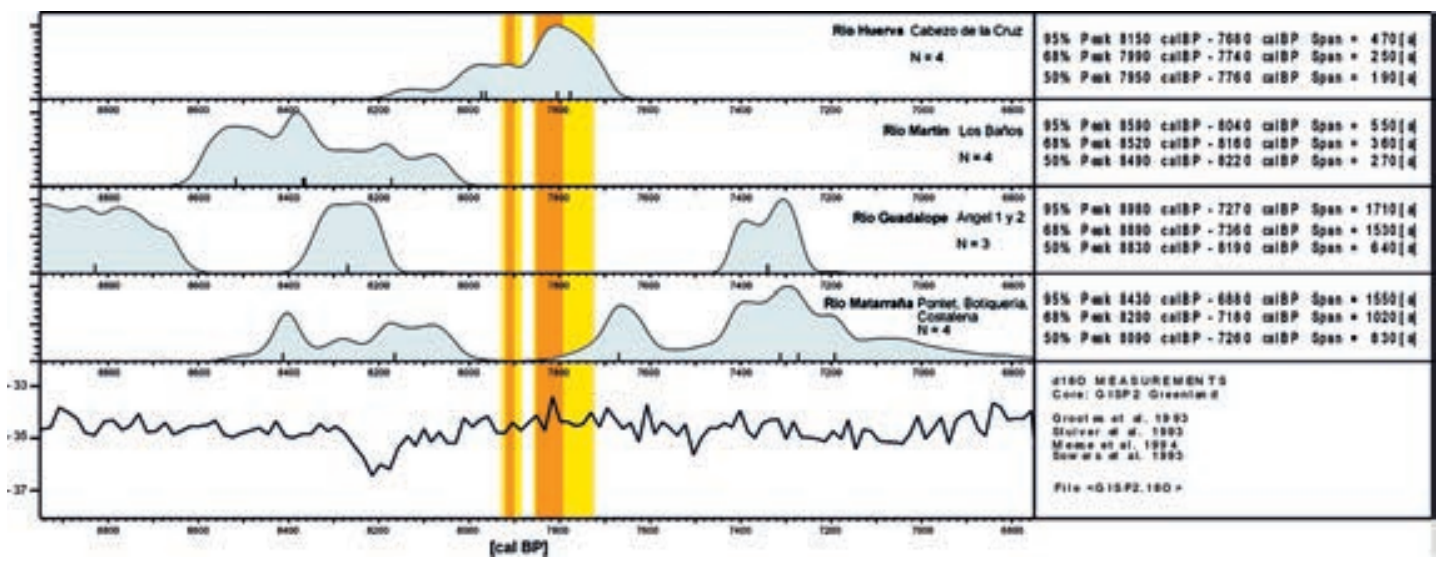

Figura 3. Dataciones calibradas del Cabezo de la Cruz con relación a los yacimientos del Mesolítico geométrico situados en la margen derecha del río Ebro dentro del territorio aragonés. Se han agrupado por cuencas. Los tramos sombreados corresponden a los intervalos asociados a 1 y 2 sigmas, calculados para las fechas promediadas del Cabezo de la Cruz.

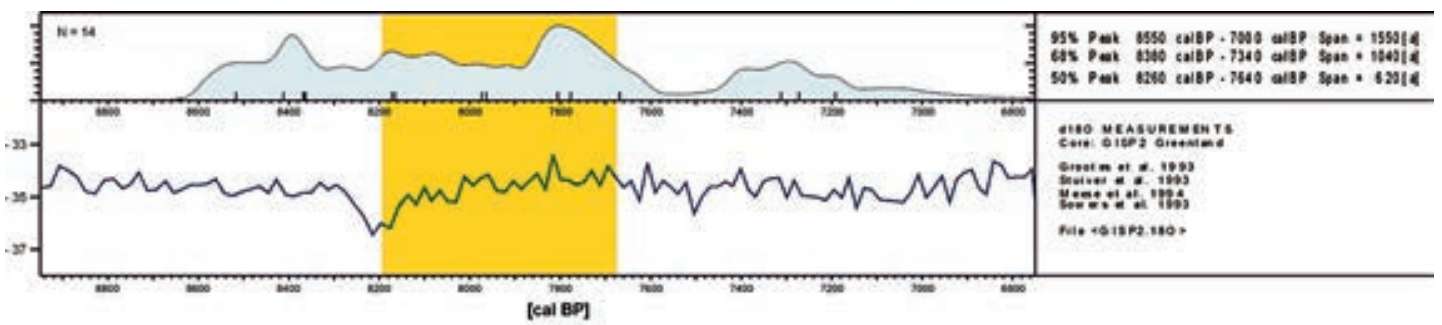

Figura 4. Dataciones de los yacimientos del Mesolítico geométrico situados en la margen derecha del río Ebro dentro del territorio aragonés. Se han excluido las dataciones de Ángel 1 y 2 por su vinculación al ámbito del Maestrazgo. Los tramos sombreados corresponden a los valores extremos del intervalo asociado a 2 sigmas, calculado para las fechas del Cabezo de la Cruz.

\footnotetext{
* Gráfico y calibraciones realizados mediante el programa CalPal de la Universidad de Colonia (Weninger y Jöris 2004). ** Intervalos calculados con el programa Calib rev6.0.0 (Stuiver y Reimer 1993), a partir de la curva INTCAL09.
} 


\begin{tabular}{|l|l|l|l|l|l|l|l|l|l|}
\hline \multicolumn{1}{|c|}{ Yacimiento } & \multicolumn{1}{|c|}{ Nivel } & \multicolumn{1}{c|}{ LAB } & BP & a.C. & \pm & $\begin{array}{c}\text { cal med } \\
B P\end{array}$ & $\begin{array}{c}\text { cal med } \\
B C\end{array}$ & $\begin{array}{c}\text { cal BC } \\
68 \%\end{array}$ & $\begin{array}{c}\text { cal BC } \\
95 \%\end{array}$ \\
\hline Costalena & c3 & GrA-10949 & 6310 & 4360 & 170 & 7190 & 5240 & 54305030 & 56004800 \\
Costalena & c3 zona alta & GrN-14098 & 6420 & 4470 & 240 & 7270 & 5320 & 56005050 & 58004750 \\
Pontet & e & GrN-16313 & 7340 & 5390 & 70 & 8170 & 6220 & 63006100 & 63806030 \\
Pontet & c inferior & GrN-14241 & 6370 & 4420 & 70 & 7310 & 5360 & 54405280 & 54705140 \\
Botiquería dels Moros & 2 & GrA-13265 & 7600 & 5650 & 50 & 8410 & 6460 & 64706405 & 65606270 \\
Botiquería dels Moros & 4 & GrA-13267 & 6830 & 4880 & 50 & 7670 & 5720 & 57655665 & 58305630 \\
Ángel 1 & 8c (U28) & GrA-27274 & 7435 & 5485 & 45 & 8270 & 6320 & 63736263 & 64286208 \\
Ángel 1 & 8c (U8-11) & GrA-27278 & 7955 & 6005 & 45 & 8830 & 6880 & 70926766 & 71056653 \\
Ángel 2 & 2a & Beta 254048 & 6390 & 4440 & 40 & 7340 & 5390 & 54455335 & 55005280 \\
Los Baños & 2b1 & GrA-21552 & 7740 & 5790 & 50 & 8520 & 6570 & 66206490 & 66506460 \\
Los Baños & 2b3 inf. & GrA-21551 & 7550 & 5600 & 50 & 8360 & 6410 & 64406290 & 64706250 \\
Los Baños & 2b3 sup. & GrA-21550 & 7350 & 5400 & 60 & 8170 & 6220 & 63006100 & 63806060 \\
Los Baños & 2b3 genérico & GrN-24300 & 7570 & 5620 & 100 & 8370 & 6420 & 65006280 & 66206200 \\
Cabezo de la Cruz & UE 1351 & GrN-29134 & 7130 & 5180 & 130 & 7960 & 6010 & 61525874 & 62915735 \\
Cabezo de la Cruz & UE 1397 & GrN-29135 & 7150 & 5200 & 70 & 7970 & 6020 & 60905956 & 61575889 \\
Cabezo de la Cruz & UE 1450 & GrN-29861 & 6970 & 5020 & 40 & 7810 & 5860 & 59095799 \\
Cabezo de la Cruz & UE 1442 & GrN-29862 & 6940 & 4990 & 50 & 7780 & 5830 & 58855767 & 59445708 \\
\hline
\end{tabular}

Figura 5. Yacimientos y fechas recogidas en los gráficos superiores. La selección de estos yacimientos y niveles se ha realizado a partir de la tabla 14 de Utrilla et al. 2009, 151.

\subsection{ECOSISTEMA}

El registro polínico del Cabezo de la Cruz no aporta datos relevantes dada la escasez de la muestra. No obstante, permite apreciar las características de la vegetación del entorno del yacimiento. El pino y los robles de hoja perenne (encina y/o coscoja) son los elementos destacados de la cubierta arbórea. Destacan en conjunto los taxones propios de ambiente mediterráneo con ciertas condiciones de humedad asociadas al curso de agua cercano (sauce, juncáceas y helechos...). Los resultados del análisis antracológico confirman en buena parte los datos anteriores a pesar de que la muestra, en este caso, es cuantiosa pero con escasa variedad de taxones. Las conclusiones más relevantes permiten afirmar que se ha utilizado poca diversidad de plantas como combustible. El más abundante es el pino carrasco que suministra materia prima para los hogares y para la construcción de la vivienda. El resto de plantas son coherentes con el ecosistema del cerro a pesar de su escasa presencia (Rhamnus-Phillyrea, Prunus sp., Labietae, Monocotiledones, Quercus sp., Juniperus sp...).

El estudio del pino carrasco, por su gran representatividad en el yacimiento, permite sacar una serie de conclusiones que no desentonan de la presencia de otras especies y son coincidentes, como luego veremos, con los resultados de otros yacimientos culturalmente comparables. Así, para el yacimiento mesolítico del Cabezo de la Cruz se puede plantear una hipótesis paleoclimática a partir de los rasgos de tolerancia térmica y de humedad del pino carrasco - que pudo formar parte de la vegetación clímax del periodo atlántico en el valle del Ebro- - Entre 12 y $19{ }^{\circ} \mathrm{C}$ de temperatura media anual y lluvias mínimas de $250 \mathrm{~mm}$ a $700 \mathrm{~mm}$ de media serían las cifras que podríamos manejar, configurando un clima mediterráneo semiárido (fig. 6).

En Los Baños la reconstrucción parte de los resultados de los análisis palinológicos de P. González (2004) y antracológicos de E. Badal (2004). Hay que recordar que no contamos con una secuencia polínica de toda la estratigrafía, los resultados válidos se concentran en el nivel 2b3, abarcando un marco temporal que ocupa la segunda mitad del VIII milenio BP. Se aprecia el predominio de pino y Juniperus, junto a Quercus t. ilexcoccifera, seguidos de elementos mesotermófilos, que configuran un clásico paisaje mediterráneo bastante abierto, con variedades de arbustos (Rhamnus, Buxus, Pistacia, Thymelaea, Ephedra, Cistus...) igualmente característicos. Es llamativa, aunque no exclusiva de este yacimiento, la ausencia de taxa que reflejen la proximidad del cauce del río Martín.

La antracología viene a confirmar y completar la secuencia ya que contamos con muestras del 2b1, lo que amplía el marco cronológico a la primera mitad del VIII milenio BP. En el tramo in- 


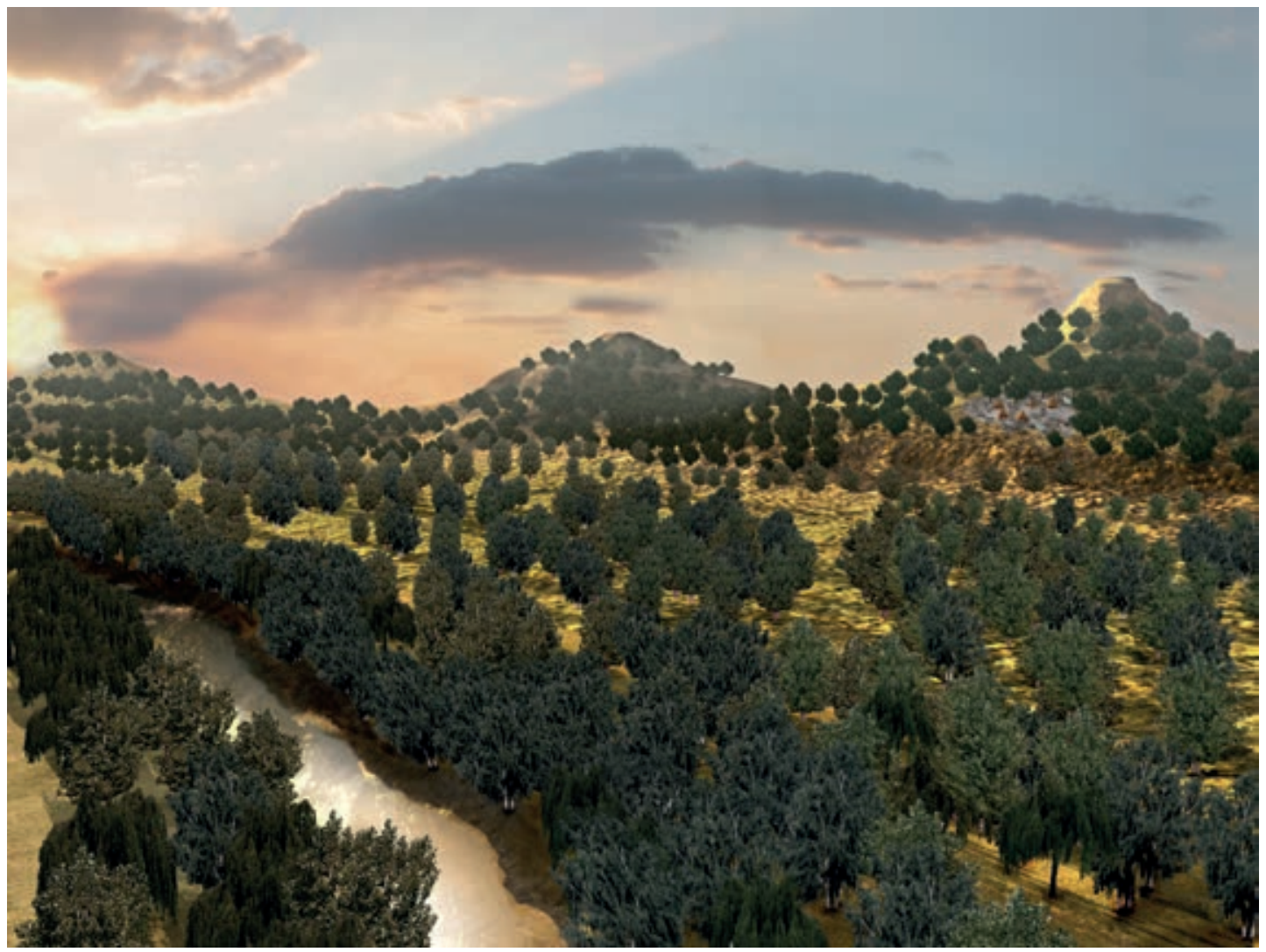

Figura 6. Reconstrucción virtual del paisaje mesolítico.

ferior, las 29 muestras analizadas corresponden a Pino, mientras que en el segundo, que coincide con 2b3, las 44 muestras ofrecen dos variedades: Pinus y Quercus, presentes de forma mayoritaria en el polen arbóreo depositado en el yacimiento (carrascas, coscojas y matorrales), aunque hay que señalar la variedad de especies de pino presentes en el yacimiento. La presencia de carcoma, detectada por E. Badal en su análisis antracológico, demuestra que la madera ha sido recogida ya seca para su combustión.

El paisaje se identifica con el tipo mediterráneo, no muy diferente al que podemos encontrar en la actualidad en algunos tramos del valle del río Martín, en el que predominan los bosques de pino y encinar y en el que se atisban los primeros indicios de una débil antropización.

Las características generales de los anteriores yacimientos son coincidentes con las de otras secuencias del Bajo Aragón, aunque presentan matices o peculiaridades propias. Existen coincidencias con las aportadas por los yacimientos más meridionales, concentrados en el Matarraña don- de se han realizado tres análisis procedentes de los yacimientos de Botiquería dels Moros, Secans y Pontet (López-García 1992; López-García y López Sáez 1992, 1996, 1998). En los tres primeros casos, a pesar de las dificultades del proceso de toma de muestras, las secuencias son coincidentes en la evolución y complementarias en los casos en los que las secuencias cubren una mayor o menor extensión cronológica.

Todas las muestras se incluyen en el Atlántico. El paisaje está caracterizado por un bosque mixto bastante abierto donde domina el Pinus halepensis sobre especies como Quercus ilex-coccifera t. o Juniperus $t$. Es un periodo cálido y húmedo marcado por una vegetación en la que se desarrollan especies termófilas como Phyllirea, mesófilas como olmo, arce, avellano, tilo o aliso, o mediterráneas como el boj.

Las características subestépicas de la vegetación y de un clima todavía semiárido quedan patentes en la presencia de Ephedra, Artemisia, Chenopodiaceae/Amaranthus, Helianthemum y Armeria/Limonium. 
Desde el punto de vista ambiental, la ocupación del Cabezo de la Cruz se produciría con posterioridad al denominado evento 8.2, un momento de recuperación climática, incluso de óptimo climático según apuntan las tendencias de las curvas paleoclimáticas utilizadas habitualmente (GISP 2). Sin embargo, las condiciones locales que afectan al Ebro Medio parecen algo más complejas si tomamos como referencia algunos trabajos como el realizado por Davis y Stevenson (2007), a partir del estudio de las lagunas de La Hoya del Castillo (Híjar, Teruel) y de Guállar (Bujaraloz, Zaragoza) (fig. 7). El referido evento 8.2 muestra un escenario en el que, en discordancia con lo que sucede en otros ámbitos europeos, especialmente en Europa, se imponen unas condiciones relativamente cálidas - en todo caso por debajo de los valores actuales- y una tasa de precipitaciones condicionada por un aumento de la actividad tormentosa durante el verano y, por el contrario, una disminución de las precipitaciones de invierno, lo que justifica un incremento de la escorrentía superficial y la subida del nivel de aquellos lagos favorecidos por tal circunstancia. Todo ello implicaría un incremento significativo de los incendios que quedaría reflejado en la acumulación de niveles con carbones (micro y macro) en los depósitos lacustres coincidiendo grosso modo con este momento.
Tras ese episodio se pasaría a una reducción de las temperaturas y a cierta recuperación de las precipitaciones, especialmente en los primeros momentos (c. 8000 cal BP) de la ocupación del Cabezo, para volver a experimentar una serie de fluctuaciones a lo largo del ciclo.

Como se aprecia en los gráficos del apartado anterior dedicado a la cronología absoluta, el evento 8.2 tendría su desarrollo en los momentos finales de la fase en la que los trapecios son dominantes. Coincidiría, a grandes rasgos, con el nivel $2 \mathrm{~b} 3$ de Los Baños (entre $2 \mathrm{~b} 3$ genérico y $2 \mathrm{~b} 3$ sup.), Pontet e o Ángel $18 \mathrm{c}$ (U 28), en paralelo a lo que se documenta en tierras valencianas donde se sitúa al final de su fase A (Martí et al. 2009, 238).

Este evento, cuya existencia nadie pone en tela de juicio, no debió de tener una importancia trascendental o no fue tan riguroso como para producir un despoblamiento generalizado en la zona. La capacidad de adaptación de estas poblaciones pudo superar las condiciones climáticas sin provocar un colapso socio-cultural y sin necesidad de abandonar estos territorios. La flexibilidad de las estrategias de subsistencia, basadas en una gran movilidad y un óptimo aprovechamiento de los recursos, se impuso a los condicionantes medioambientales.

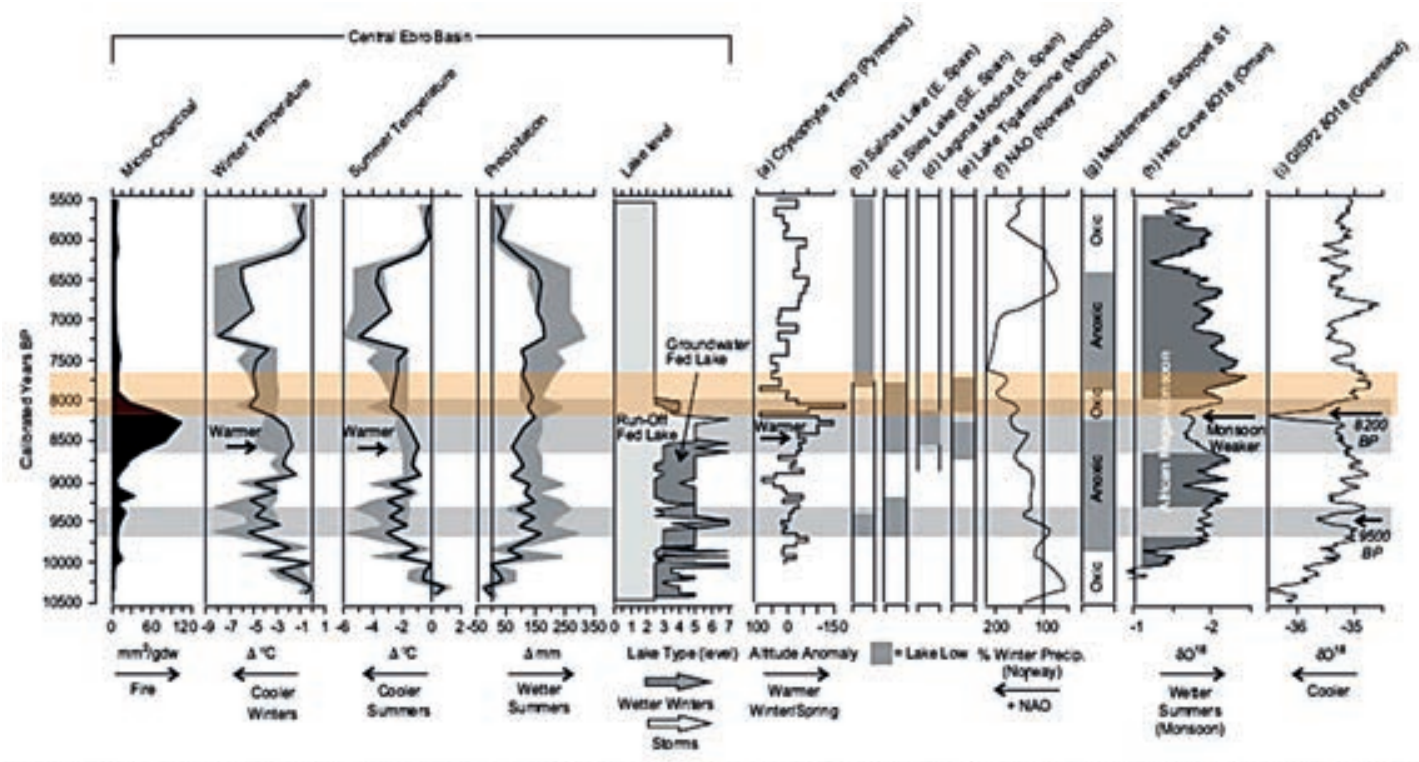

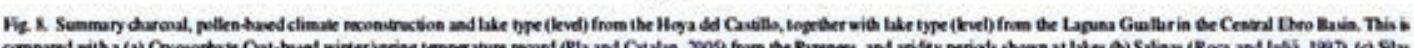

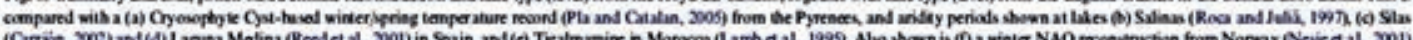

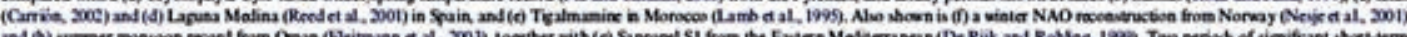

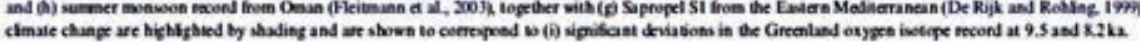

Figura 7. Gráfico de las tendencias climáticas del Holoceno medio-antiguo registradas en el valle del Ebro a partir de los estudios realizados en las lagunas de Hoya del Castillo y Guállar (Davis y Stevenson 2007, 1708). En color, la franja correspondiente a las dataciones del Cabezo de la Cruz. 


\subsection{SOBRE HÁBITAT Y TERRITORIO}

\subsubsection{HÁBITAT}

La existencia de una cabaña al aire libre, hecho poco frecuente entre los tipos de asentamientos identificados en el Mesolítico peninsular, no debió ser tan excepcional entre los cazadores-recolectores de la primera mitad del Holoceno.

En el caso del valle medio del Ebro, en la propia Zaragoza, en el solar ocupado por el Instituto Bachillerato Mixto 4, se encontró lo que parecía un fondo de cabaña excavado en limos, con hogar en forma de cubeta, agujeros de poste, restos de talla de sílex y sin cerámica (Álvarez y Mostalac 1997, 254). Aunque el material recuperado es poco significativo, este tipo de emplazamiento, una posible cabaña sobre las terrazas del Ebro, es un nuevo referente que nos hace intuir la posibilidad de una considerable generalización de los hábitats al aire libre.

Más aún, un repaso no exhaustivo de los yacimientos líticos superficiales, vinculados de manera genérica a las etapas finales del Neolítico, permite constatar con cierta frecuencia la presencia de geométricos y otros elementos asociados, caso de microburiles, con cierta regularidad en conjuntos al aire libre.

Tomando como marco espacial de referencia el territorio aragonés, en casi todas las zonas donde se han llevado a cabo prospecciones con alguna intensidad, como son diversos sectores del prepirineo, somontanos ibéricos o Bajo Aragón, se identifican conjuntos en los que están presentes estos elementos.

Sin embargo, tradicionalmente se ha prestado poca atención a esos componentes geométricos y no siempre se han valorado de forma correcta. A la problemática propia de los yacimientos líticos de superficie se une su presencia generalmente minoritaria y su escasa visibilidad, su disolución en conjuntos con otros artefactos como puntas de tipo foliáceo, elementos de hoz y cerámicas que denotan etapas más avanzadas y ciertas incertidumbres sobre la cronología de estos productos debido a su pervivencia en algunos contextos neolíticos. Hemos de tener en cuenta que la frecuencia de geométricos en yacimientos excavados es, en general, baja, aún contando con que se lleva a cabo una recuperación integral de los restos y el cribado sistemático de los sedimentos. Tomando como referencia la propia cabaña del Cabezo de la Cruz, en el conjunto de niveles mesolíticos se han recuperado 12 geométricos entre un total de 1750 restos líticos, lo que supone un índice de densidad de 0.007 . Idéntico valor es el obtenido para el yacimiento neolítico al aire libre de Riols I, con 9508 restos líticos y 68 geométricos (Royo y Gómez 1992, 304), índices, por otra parte, muy similares al obtenido en otros yacimientos en abrigo como Els Secans (Rodanés, Tilo y Ramón 1996). Concretamente en este lugar entre 6933 restos líticos se recuperaron 41 geométricos, lo que proporciona un índice de 0.006 . Todo esto supone que para encontrar un geométrico hay que recuperar alrededor de 150 elementos líticos, lo que no siempre es posible en los contextos superficiales. Además hay que insistir en la escasa visibilidad de estos elementos microlíticos, lo que, sin duda, repercute en una subrepresentación en los conjuntos superficiales.

Desde los trabajos pioneros de Vallespí (1959) o los análisis realizados por Barandiarán y Cava $(1981,98)$ se viene insistiendo en la problemática de estos conjuntos, siendo el aspecto más relevante el hecho de que nos encontramos ante conjuntos superficiales descontextualizados, carentes de estratigrafía o, al menos, no documentada y, en muchos casos, en depósitos secundarios. A ello debemos añadir la posibilidad de que, en ciertos casos, constituyan auténticos palimpsestos de ocupaciones diversas que generan la mezcla de materiales de diferentes cronologías en superficie creando un problema añadido para su correcta interpretación y datación (Rodanés y Picazo 2005, 18 y ss.).

También es cierto que los conjuntos líticos superficiales que presentan elementos potencialmente mesolíticos son realmente escasos. En una reciente síntesis (Utrilla et al. 2009, 138) se recogen algunos de los pocos hallazgos al aire libre, como Vardalgal (Morata de Jalón), con un trapecio de retoque abrupto y un microburil, otro microburil en El Parrizal, también en la cuenca del río Grío, a los que podemos añadir un tercero en la partida de las Viñas Viejas de Longares (Utrilla y Gimeno 1981). Pero de una forma un tanto dispersa podemos ir anotando otros hallazgos que cubren casi toda la geografía aragonesa. Por ejemplo, en el rico núcleo de las Cinco Villas, con numerosos conjuntos que incorporan microburiles o dorsos, podemos destacar el yacimiento de Salomé II (Ejea de los Caballeros, Zaragoza), con una laminita de dorso fragmentada y un triángulo con retoque abrupto en un conjunto en el que está ausente la cerámica aunque aparece un fragmento 
de hacha pulimentada (Lanzarote, Ramón y Rey 1991,99-100), y no nos resistimos a anotar el yacimiento de Miramonte en Ardisa, ya cerca del río Gállego, donde se cita un triángulo con retoque abrupto junto con cerámicas a mano, entre ellas un fragmento campaniforme, e islámicas (Lanzarote, Ramón y Rey 1991, 40-41).

En la margen derecha del Ebro, también se rastrea algún elemento a tener en cuenta: recientemente hemos localizado un conjunto lítico en La Cuesta del Herrero (Mezalocha, Zaragoza) donde encontramos un trapecio achaparrado junto con otros restos poco significativos y escasos fragmentos de cerámica a mano. En Salada Grande Este I (Alcañiz, Teruel) se citan dos, algún raspador, trapecios junto con restos de talla de sílex y contados fragmentos de cerámicas a mano de diversas épocas (Benavente et al. 1991, 62). En El Morrón (Obón, Teruel), sobre el rellano formado en medio de una ladera, en la confluencia entre dos barrancos, se encontró una posible cabaña circular identificada por una serie de lajas hincadas, asociada a un conjunto de esquirlas y fragmentos de pequeñas lascas, con pocos elementos significativos entre ellos una porción de laminita y un posible microburil (Picazo y Loscos 2003-2004, 33-35).

Todos estos datos, aunque con importantes incertidumbres, no nos permiten obviar la hipótesis de un poblamiento mesolítico al aire libre bastante generalizado a lo largo del valle del Ebro, con una importante penetración a través de sus afluentes laterales. Este poblamiento parece vinculado a esos ríos y a una serie de cauces secundarios que sirven de vías de comunicación transversal entre ellos y con las tierras más elevadas de los somontanos y sierras. Buena parte de los hallazgos citados y otros similares parecen vincularse a ocupaciones próximas a los ríos, muchas veces donde confluyen otros cauces subsidiarios, en puntos ligeramente elevados, con buena visibilidad sobre el entorno, pero protegidos, aprovechando el abrigo de laderas medias o bajas con buena orientación en el rango SE-SO, es decir, un modelo similar al documento en el Cabezo de la Cruz.

Pero este modelo no parece exclusivamente ligado a los supuestos yacimientos con componentes geométricos, sino que es posible rastrearlo con anterioridad en yacimientos que pueden encuadrarse, de nuevo con ciertas incertidumbres, en lo que se viene denominando un epipaleolítico de tipo macrolítico o de denticulados (Barandiarán y Cava 2002; Utrilla et al. 2009), bien representado en abrigos como Peña 14, nivel Ib de Forcas II, Ib de Los Baños, Abrigos de Ángel, Plano del Pulido, etc., y datado entre el 8500-8000 BP. De hecho, algunos conjuntos superficiales; que en su momento tuvimos ocasión de estudiar en el valle medio del Jiloca como Varadente, El Mas o La Umbría del Mas (Picazo 1986; 1993, 70), con industrias poco características dominadas por núcleos prismáticos e informes, lascas, muescas y denticulados, algunos de cierto tamaño, y otros elementos minoritarios como raspadores, láminas retocadas, perforadores, etc., podrían inscribirse en estos momentos, representando de alguna forma un precedente donde se rastrea el modelo de ocupación al aire libre que venimos describiendo. De hecho, según Barandiarán y Cava $(2002,309)$ la amplia dispersión de niveles de la fase de denticulados o macrolítica por todo el valle del Ebro hace suponer que representa «la primera ocupación relativamente densa del espacio interior de la cuenca del Ebro y que sigue unos parámetros - en cuanto a elección y estructuración de los asentamientos y de los territorios de explotación- que después continuarán vigentes puesto que, en la mayoría de los sitios, supondrán los niveles con este equipamiento la base de una secuencia estratigráfica continuada». Por tanto, algunos yacimientos al aire libre, aunque no tengamos constancia de esa continuidad estratigráfica, bien pueden explicarse bajo esta misma hipótesis pues, además de su sintonía en los componentes materiales, no dejan de reproducir el mismo modelo económico y territorial ligado a los grupos cazadores-recolectores epipaleolíticos, ya ocupen abrigos o establezcan sus campamentos al aire libre, dentro de ese proceso de generalización por todo el territorio.

Por otra parte, si es posible rastrear el origen de ese poblamiento al aire en los conjuntos macrolíticos o de muescas y denticulados y su desarrollo posterior con las formas geométricas, la continuidad también queda patente en numerosos yacimientos líticos superficiales que incorporan elementos geométricos de cronología más avanzada como es el caso de los triángulos y, especialmente, segmentos con retoque en doble bisel, más propios del neolítico.

De hecho, en el rastreo sumario de elementos geométricos que hemos realizado, la mayoría de los conjuntos al aire libre seleccionados incorporan estos tipos.

La aparición del retoque en doble bisel se vincula con el proceso de neolitización del territorio 
más que con ocupaciones claramente mesolíticas a partir de fechas alrededor del 6800 BP. No obstante, teniendo en cuenta que la mayoría de abrigos con secuencias amplias en las que incorporan este tipo de artefactos denotan un proceso de aculturación de las comunidades indígenas locales, esa misma circunstancia tuvo que afectar a las ocupaciones al aire libre y, por tanto, alguno de estos yacimientos líticos con segmentos con doble bisel seguramente reproducen el patrón tradicional de los asentamientos que los grupos de cazadores recolectores mesolíticos venían utilizando en sus desplazamientos por el territorio. A este respecto, yacimientos como Boquera del Regallo II, en la confluencia de río Algás con el Ebro, con un conjunto lítico con varios geométricos, entre ellos un segmento con doble bisel, laminitas de dorso, microburiles, etc., bien pueden representar esta tendencia que marca la continuidad y transición entre los complejos de cronología mesolítica y neolítica también en contextos al aire libre (Álvarez 1985, 90-92).

Más allá de este enclave concreto, la dispersión de yacimientos con segmentos con retoque en doble bisel es amplia y generalizada por todo el territorio, desde el ámbito más septentrional del valle, en yacimientos como La Barbera VI (Uncastillo) (Lanzarote, Ramón y Rey 1991, 261) y otros similares de las Altas Cinco Villas, hasta las serranías ibéricas hacia el sur, en sitios como Las Tierras Blancas (Algairén) (Burillo [ed.] 1993, 269) o El Pizarral I de Obón (Picazo y Loscos 2003-2004, 34), en este caso con un triángulo con doble bisel. En las inmediaciones del propio Cabezo de la Cruz, en una de las terrazas de la margen izquierda del río Huerva encontramos un conjunto lítico sin cerámica denominado Muel I (Pérez, Fanlo y Picazo 2010, 296) que entre sus exiguos restos incorpora un segmento y un microburil, que bien puede indicarnos una continuidad en la ocupación de este ámbito geográfico en los inicios del Neolítico.

De nuevo, alguno de estos yacimientos se encuadran bien en el Modelo Neolítico I de tradición epipaleolítica que implica la integración de elementos neolíticos en contextos mesolíticos, incorporación favorecida por la movilidad de estas poblaciones que no modifican de forma sustancial su sistema socioeconómico (Rodanés y Picazo 2005, 77, fig. 5).

Pero tampoco podemos perder de vista que esos mismos componentes materiales continúan en periodos más avanzados, en el denominado Neolítico II, cuando culmina el proceso de transformación con la plena incorporación de la economía productiva (cfr. Rodanés y Picazo 2005, 82). La aparición de nuevos artefactos como los elementos de hoz, láminas relativamente anchas... y sutiles cambios en los patrones de asentamiento vinculados a las nuevas necesidades económicas aunque se sigan ocupando similares territorios, ponen de manifiesto este cambio y seguramente corresponde a este momento la máxima generalización de los yacimientos líticos con segmentos, caso de los numerosos conjuntos de las Cinco Villas (Lanzarote, Ramón y Rey 1991) o de la comarca del Bajo Cinca (Sopena 1992).

Como conclusión de este rápido recorrido a través de una parte de los yacimientos líticos superficiales identificados en el territorio aragonés podemos deducir que la cabaña documentada en el Cabezo de la Cruz no parece la excepción sino más bien el ejemplo de una amplia red de asentamientos localizados al aire libre distribuidos por buena parte del valle del Ebro. El modelo de ocupación asociado no difiere al puesto de relieve por los abrigos del Bajo Aragón o del valle del Ebro, en general, siendo la proximidad a los ríos, buena orientación, protección frente a los vientos dominantes, control visual del entorno inmediato y proximidad a vías de comunicación natural, alguno de los rasgos estructurales que de alguna forma determinan la selección del emplazamiento.

Idéntica situación podemos apreciar en el País Valenciano. En la reciente síntesis sobre el Mesolítico reciente (Martí et al. 2009) se comentan una serie de lugares al aire libre que presentan rasgos comunes y dinámicas similares con los que hemos señalado en comarcas aragonesas. Así se señalan yacimientos como Mas de Sanc (Albocàsser), Sitjar Baix (Onda), Estany Gran (Almenara) en Castellón; La Mangranera (Andilla), Muntanya del Cavall (Albalat dels Tarongers), La Ceja (Dos Aguas), Albufera de Anna (Anna), El Collao (Oliva) en Valencia; Barranc de l'Encantada (Beniarrés), Mas del Regadiulet (Alcoy en Alicante. No todos ellos suministran idéntica información, ni posiblemente tuvieron la misma funcionalidad. No los vamos a comentar de manera pormenorizada ya que en la publicación citada se hace referencia a la bibliografía esencial sobre los mismos (Martí et al. 2009, 211-224). Lo que queremos destacar es que su aparición no es un rasgo distintivo del País Valenciano (Martí et al. 2009, 247) si no que, teniendo en cuenta lo descrito en párra- 
fos anteriores y con los ejemplos que detallamos a continuación y de manera somera, es un fenómeno generalizado que alcanza, igualmente, al Alto Ebro y País Vasco.

En La Rioja desde los primeros trabajos de L. Pericot que dio la noticia de las series de Ortigosa de Cameros, que casualmente consideró mesolíticas, y que posteriormente fueron estudiadas por E. Vallespí, rebajando su cronología, hasta los trabajos más recientes sobre el valle del Iregua (Rodanés 1991) y los yacimientos de la Dehesa de Navarrete (Rodanés y Pascual 1982), las series de la cuenca del Najerilla (Barrios y Pérez Arrondo 1986) o los más recientes de Holloba en Tirgo o La Llana (Barrios y Porres 2006).

En el País Vasco y Navarra el panorama es similar y son muchas las estaciones líticas que, a pesar de la heterogeneidad de sus materiales, componen un mosaico de lugares en los que el componente geométrico no es desconocido. Así aparece reflejado en numerosos estudios, algunos ya clásicos como la tesis de Beguiristain (1982) o los de E. Vallespí que aportan un nutrido repertorio, muchos de ellos recogidos en la Prehistoria de Navarra con su bibliografía correspondiente (Barandiarán y Vallespí 1980) o en la Carta Arqueológica de Álava (1987), junto a otros más recientes (Armendáriz e Irigaray 1991-1992). No obstante, como bien señalan Alday y Cava $(2009,101)$ entre las numerosas citas y publicaciones de «agregados líticos», solo unos pocos presentan materiales que pudieran por tipología asimilarse a estos momentos: Argutxi I, Igurita (sierra de Encia-Iturrieta), Fuente de Eviso, Raso de Zatola (sierra de Urbasa), Landa y Saldarroa o Itseatsi.

En suma, podríamos afirmar que el hábitat en estos momentos es, quizás, el más variado de la prehistoria, al igual que sucede en gran parte de Europa occidental. Los emplazamientos se sitúan en terrenos llanos con suelos de arena, limos o arcillas en llanuras y valles del interior, en las zonas costeras, en bordes de mesetas o altiplanos, en valles junto a cauces de ríos, incluso en menor medida en lugares elevados. Igualmente coexisten los asentamientos al aire libre junto a abrigos situados cerca de los cursos de agua y cuevas calizas en menores porcentajes (Rozoy 1978, 1153). Lo habitual a partir del Preboreal sería el hábitat al aire libre con ocupaciones de varios meses y que precisamente las cuevas y abrigos serían ocupadas más ocasionalmente (Rozoy 1978, 1101).
La disposición del campamento del Cabezo nos sugiere la existencia de un campo base por su probable extensión y situación pero no deja de ser una hipótesis difícilmente demostrable. Lo mismo ocurriría con los demás yacimientos del Bajo Aragón dada la amplitud de los niveles y la presencia de distintas actividades, Si esta ocupación fue anual o estacional, tampoco lo podemos saber, es cierto que debió ser intermitente como ya hemos apuntado en otras ocasiones, pero sin poder determinar su dimensión temporal.

\subsubsection{Estructuras}

No son frecuentes los hallazgos como el que estamos estudiando. Al aparecido, y ya comentado, del solar zaragozano, debemos añadir alguno de reciente publicación como Benàmer (Muro d'Alcoi, Alicante) donde se han documentado restos de un grupo de cazadores recolectores mesolíticos, entre 6800-6000 cal BC (Beta-287331: $7480 \pm 40$ BP y CNA-680: $7490 \pm 50$ BP) localizados en el área 4 sector 2. A diferencia de la cabaña que estudiamos, no se han encontrado restos o improntas de postes, por el contrario, destaca una estructura de empedrado o encachado con una morfología rectangular alargada. El conjunto se interpreta como un «área primaria de actividad de un pequeño grupo», o bien una base o acondicionamiento del terreno utilizado para la instalación de cabañas o espacios de vivienda. Las materias primas líticas seleccionada son locales, se corresponden con las existentes en los alrededores del yacimiento, en las terrazas del Serpis o en laderas y piedemontes de las sierras próximas. Recogidas superficialmente y transportadas al yacimiento que presenta todas las fases de producción lítica o toda la cadena operativa (Jover 2011, 141-142). El componente geométrico es significativo con un acusado predominio de formas trapeciales, lo que, unido a las dataciones, sitúa el conjunto en la fase A.

Pareko Landa en Vizcaya pudiera ser el testimonio de una estructura susceptible de ser comparada a la que estamos estudiando. Presenta dos fases de ocupación, la más reciente con trapecios abruptos podría asimilarse a un horizonte similar al que estudiamos:

Es un lugar de hábitat temporal, posiblemente estacional, que se mantiene durante más de dos milenios en relación con un modelo de explotación intensiva de recursos diversos. Debido a la acidez del depósito, no se han conservado restos de fauna. Aun así la industria lítica, con una interesante secuencia de evolución de las armaduras 


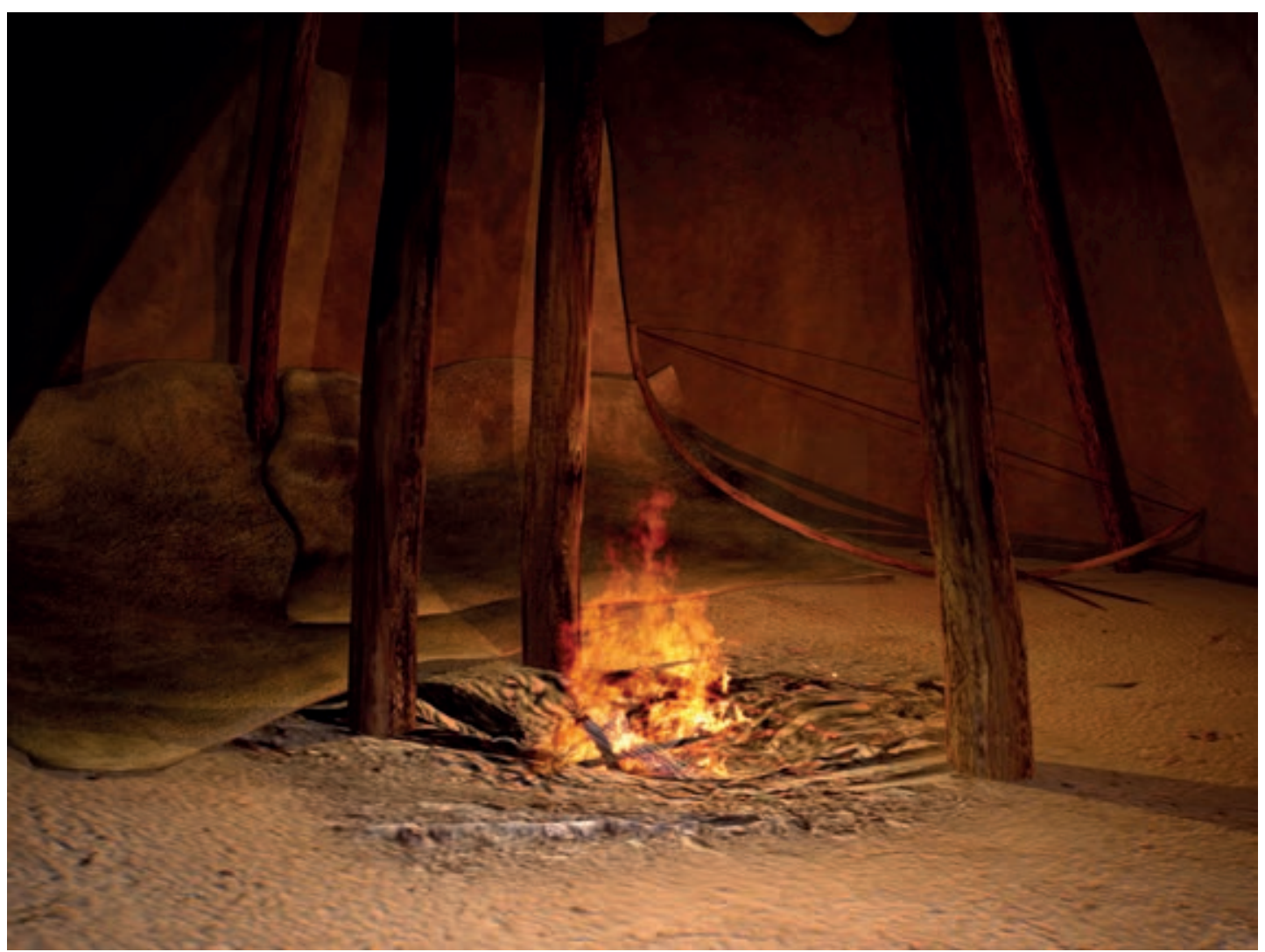

Figura 8. Reconstrucción virtual del interior de la cabaña.

microlíticas, y su posición geográfica, en un collado de altura, hacen pensar en una ocupación desde donde se efectúan actividades cinegéticas, sin menospreciar otros aprovechamientos del medio, como, por ejemplo, la recolección de productos botánicos. Se trata, pues, de un establecimiento propio de grupos con una economía de amplio espectro (López Quintana 1996, 63).

Las dataciones absolutas, en algunos casos erráticas, sitúan los horizontes con escasa precisión. Las que pudieran relacionarse con el horizonte que estamos estudiando corresponderían a $7510 \pm 100$ BP (I-Smk) y 6650ะ130 BP (López Quintana y Aguirre 1997).

Las estructuras que delimitan espacios de ocupación son escasas, incluso en territorios con más información como el occidente europeo (Rozoy 1978, 1091). Existen, no obstante, ejemplos comparables con los identificados en el valle del Ebro. Así, a pesar de que en el caso de los lugares al aire libre muchas veces hay que recurrir a la dispersión de los objetos, también se documenta, aunque más raramente, la presencia de restos constructivos.
Destacaremos la cabaña de Howick (Northumberland) de 5 a 6 m de diámetro (<research.ncl.ac.uk/ howick/>). Otros lugares en Francia permiten deducir la existencia de campamentos o viviendas de la época como en Ruffey-sur-Seille o Choisey en el Jura (Ghesquière y Marchand 2010, 109).

Otras, igualmente, susceptibles de ser identificadas como restos de viviendas, aparecen en el interior de abrigos. En Secans se localizó una posible cabaña, que cerraba un espacio delimitado por grandes bloques de piedra y posiblemente recrecido con una cubierta vegetal (Rodanés, Tilo y Ramón 1996). En el nivel IIIb2 de Atxoste, se documentó igualmente una pequeña arquitectura adosada a la pared, con un hoyo central delimitado por piedras, donde apoyaría un poste de sustentación, con un espacio útil de unos 13 metros cuadrados (Alday y Cava 2009, 103).

En Sonchamp III, Yvelines, la dispersión de materiales, en el interior del abrigo, en torno a un hogar, permite identificar una cabaña de 3 o $4 \mathrm{~m}$ de diámetro. En Monclús, en los niveles castelnovienses se descubrió una estructura circular de 


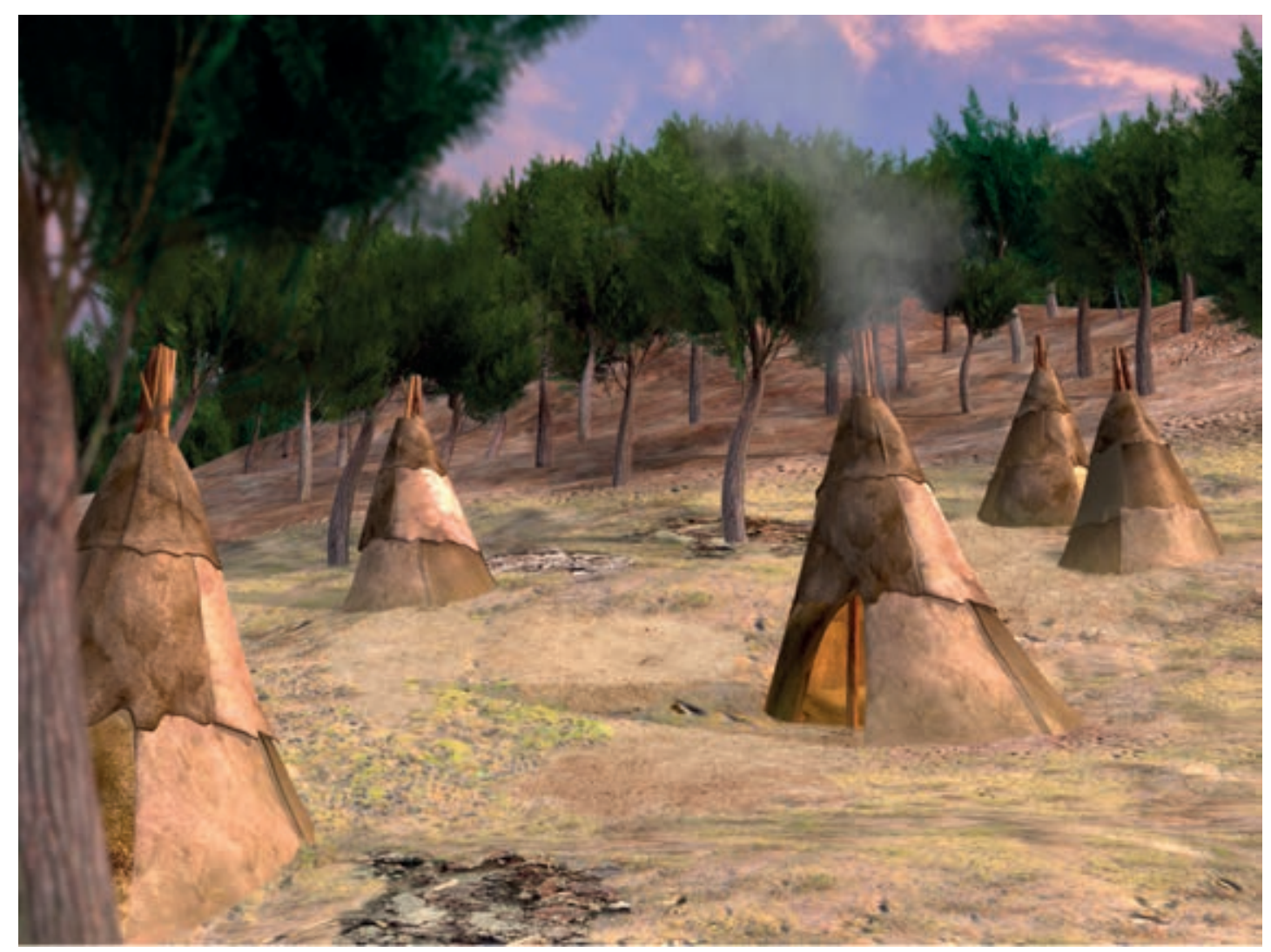

Figura 9. Reconstrucción virtual de las cabañas del campamento mesolítico.

unos $4 \mathrm{~m}$ de diámetro con la posible huella de un poste descentrado, estructura bastante similar a la del abrigo de Mollendruz en Mont-la Ville (Suiza), comparable, incluso, con la aparecida en el nivel 6 de Balma Margineda en Andorra (Ghesquière y Marchand 2010, 109; Rozoy 1978, 1091 y ss.).

Los únicos elementos internos significativos documentados, tanto al aire libre como en el interior de abrigos, son, en algunos casos, los postes de sustentación (Cabezo de la Cruz, Pontet o Atxoste) pero los más significativos y numerosos son los hogares de distintos tamaños y disposiciones: los hay en cubetas como el Cabezo de la Cruz (fig. 8), Secans o Atxoste, con distintas dimensiones que oscilan en ocasiones desde el metro de diámetro a simples acumulaciones de cantos o cenizas (Ghesquière y Marchand 2010, 113), como hemos apreciado en lugares como Costalena, Botiquería o Pontet (Barandiarán y Cava 2002, 307).

Las cubiertas de las cabañas de esta época pudieron realizarse con pieles o materias vegetales. Existen testimonios etnográficos que contemplan ambas posibilidades. En el caso del Cabezo nos inclinamos por pieles ya que suponemos que la cubierta vegetal hubiera dejado más restos antracológicos o polínicos. Ante esta ausencia pensamos que las pieles pudieron ser una buena fórmula de techado (fig. 9). Las reconstrucciones experimentales (Bordes y Gaussen 1970) estiman unas 20 pieles para una tienda de $3 \mathrm{~m}$ de diámetro por 3 de alto si bien es cierto que esto genera más problemas logísticos y de transporte que si se hubiesen realizado con materias vegetales. Esta es la opción que hemos elegido en la reconstrucción virtual frente a otras igualmente factibles como la anteriormente comentada de Howick, reconstrucción diseñada con elementos vegetales (<research.ncl.ac.uk/howick/>).

\subsubsection{TERRITORIO}

La ubicación de la cabaña mesolítica del Cabezo de la Cruz en la margen izquierda del río Huerva reúne unas excelentes condiciones de habitabilidad. Se trata de una ocupación en una suave ladera, con pendiente en torno al 13-14\%, al pie de un cerro testigo que le sirve de protección frente a los vientos dominantes del NO y con orientación S-SE y, por tanto, una buena insola- 


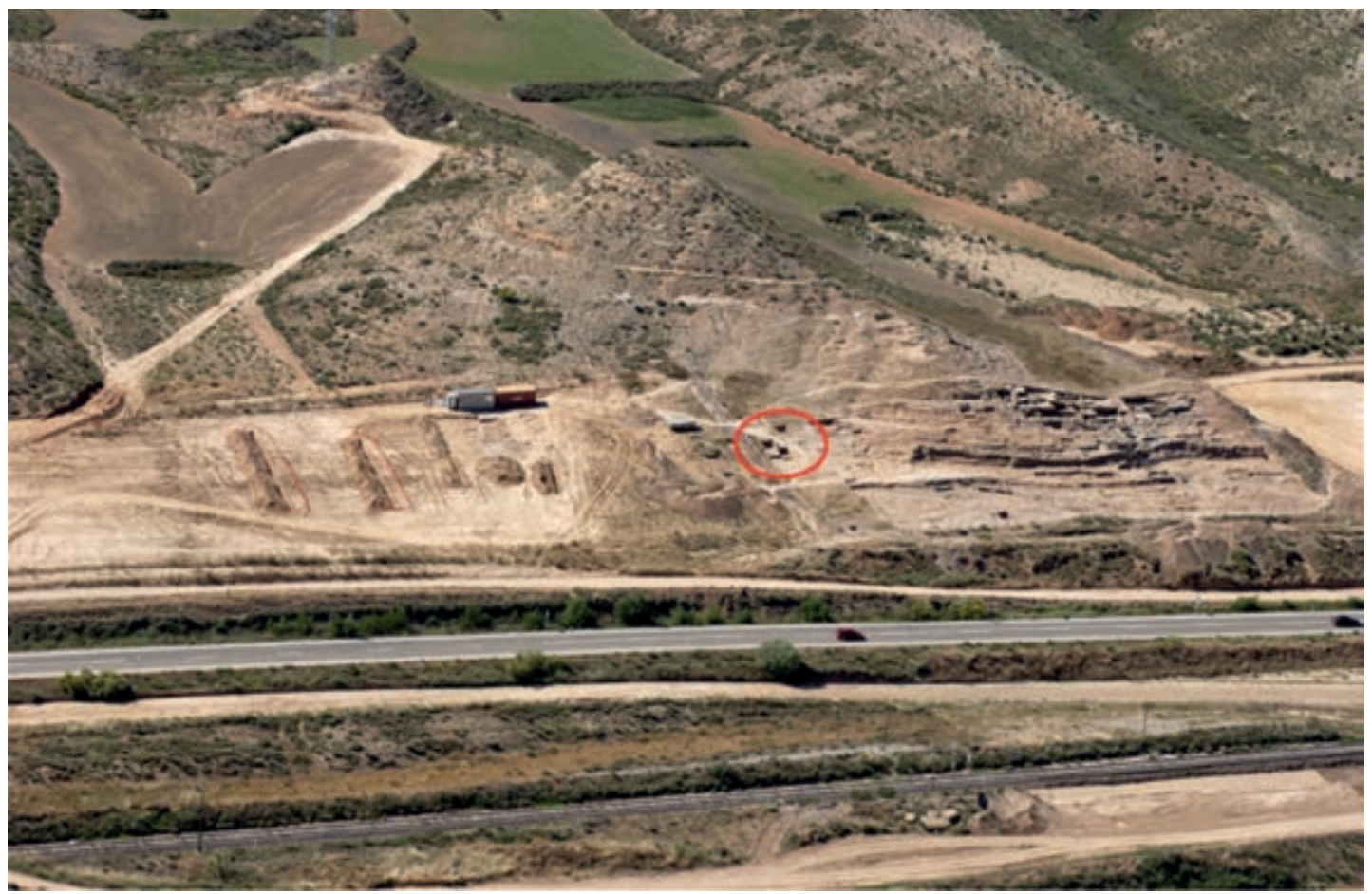

Figura 10. Vista aérea desde el SE de la ubicación de la cabaña mesolítica al pie del Cabezo de la Cruz.

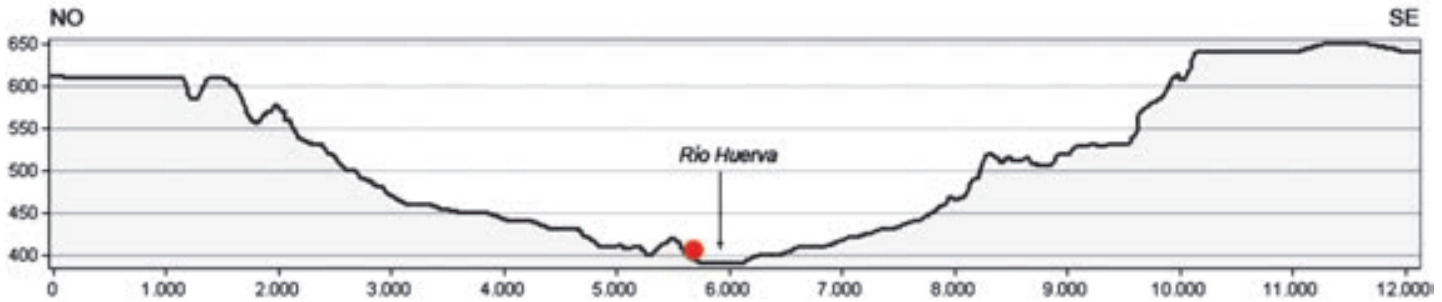

Figura 11. Perfil topográfico del valle del río Huerva a la altura del Cabezo de la Cruz. Posición de la cabaña en rojo.

ción. La distancia al cauce actual del río no llega a los $300 \mathrm{~m}$ y el desnivel apenas alcanza los $20 \mathrm{~m}$. Esta posición y proximidad al río le proporciona un fácil abastecimiento hídrico, el aprovechamiento de los recursos que ofrece ese entorno, un buen control sobre el mismo y mantenerse a salvo de posibles inundaciones o avenidas tanto del cauce principal como de barrancos laterales (fig. 10).

A su vez, aunque actualmente el entorno del yacimiento, más allá de la zona de inundación del río Huerva, aparece como una área seca, deforestada y sometida a procesos erosivos muy intensos, también reúne una serie de condiciones interesantes de cara a posibles aprovechamientos (fig. 11). Por estas razones, con objeto de entender la ubicación no solo en función de los rasgos del lugar sino también del entorno, hemos explorado las áreas de interés potencial a través de la determinación de los territorios teóricos de explotación a distancias de una y dos horas de desplazamiento desde el yacimiento, así como el alcance, dirección y eficacia de las áreas controladas visualmente.

Para determinar los territorios teóricos de explotación se ha calculado el coste acumulado en los desplazamientos en torno al Cabezo de la Cruz con objeto de establecer las isocronas correspondientes a una y dos horas, es decir, el límite máximo de terreno al que se puede acceder desde el yacimiento en esos intervalos temporales.

Para la determinación de estas isocronas se ha aplicado la propuesta de Davidson y Bailey (1984), 


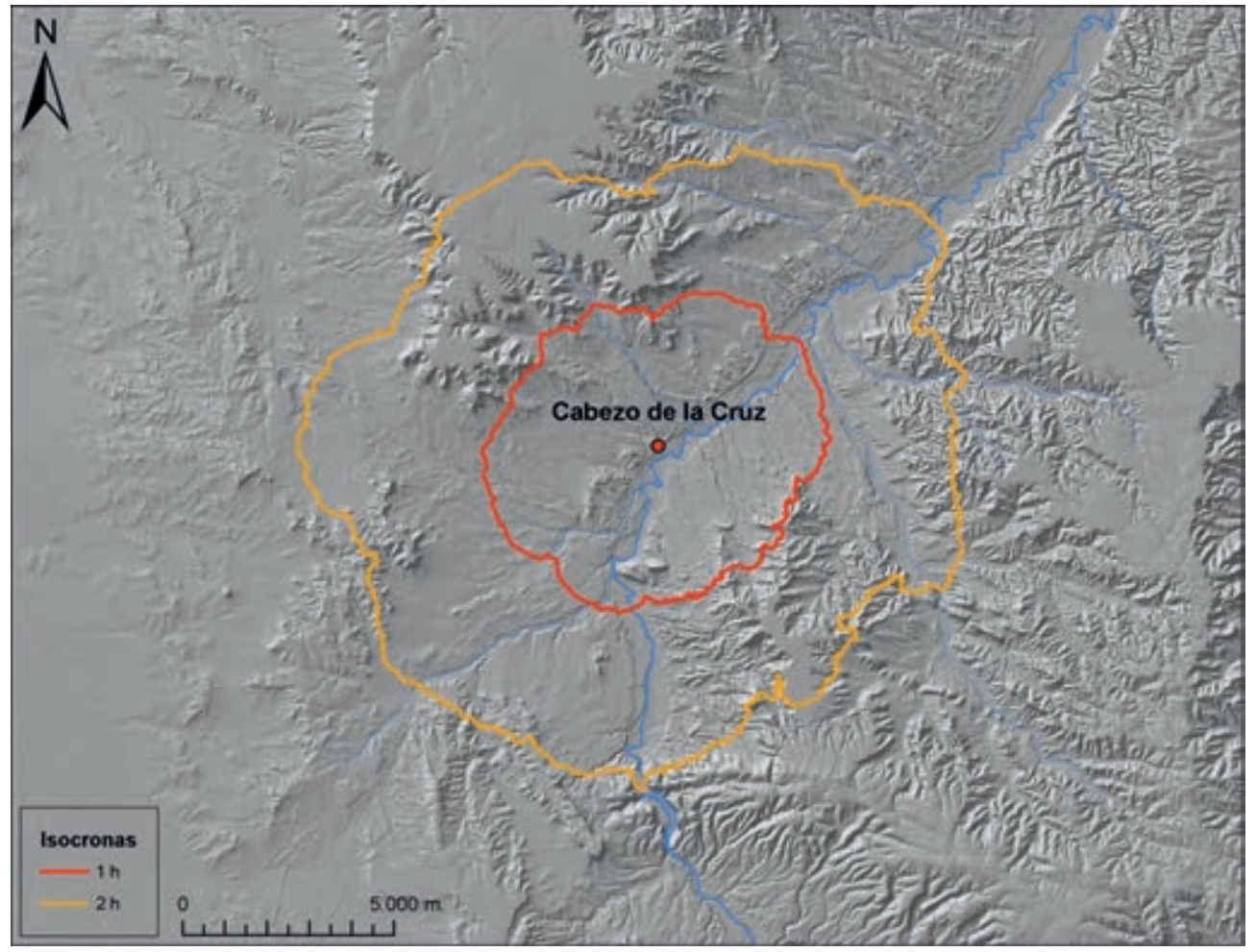

Figura 12. Territorios de explotación (isocronas de 1 y 2 h) en torno a la cabaña mesolítica del Cabezo de la Cruz.

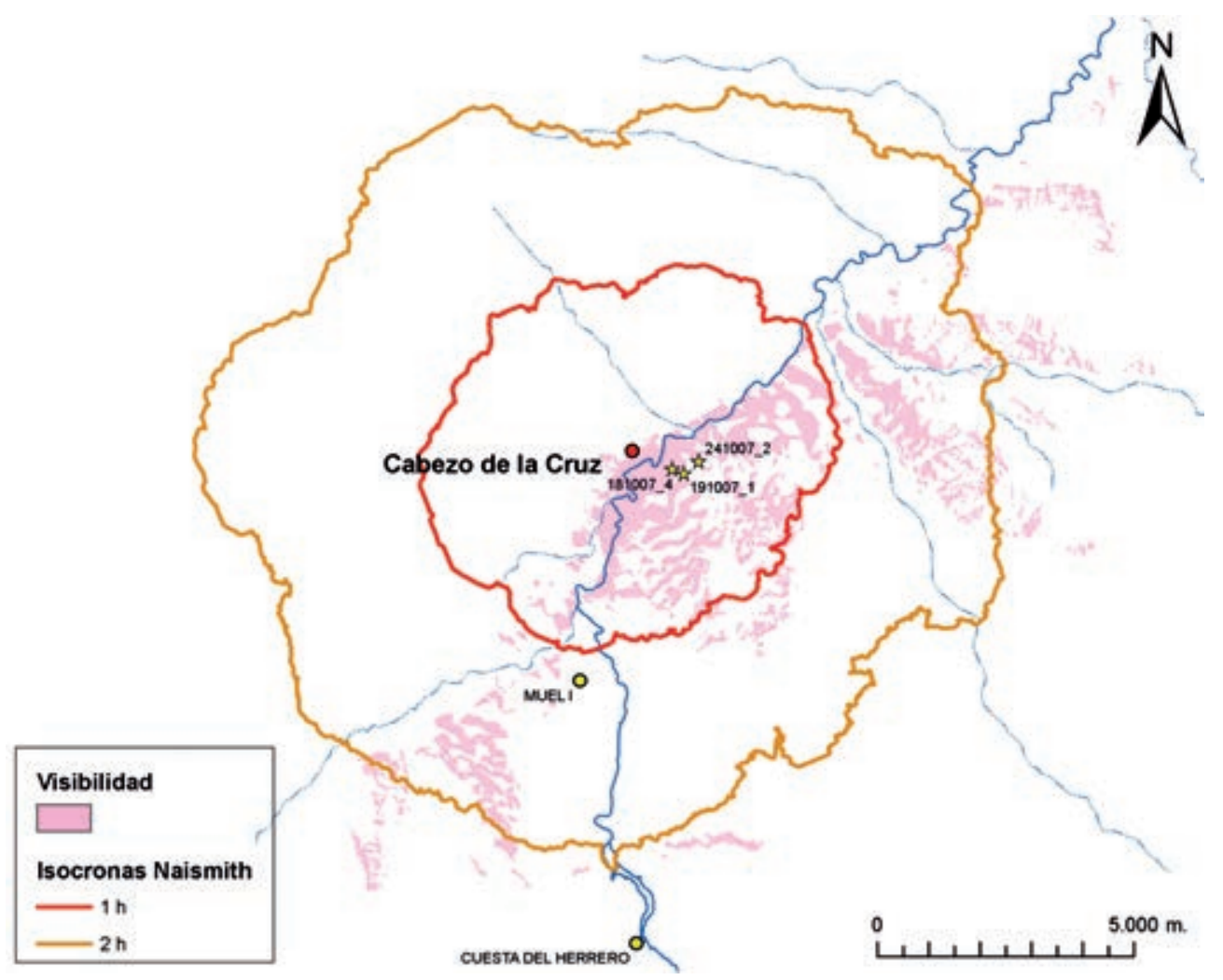

Figura 13. Cuenca visual con relación a los territorios teóricos de 1 y 2 h en torno a la cabaña mesolítica del Cabezo de la Cruz y principales yacimientos localizados en el entorno. 


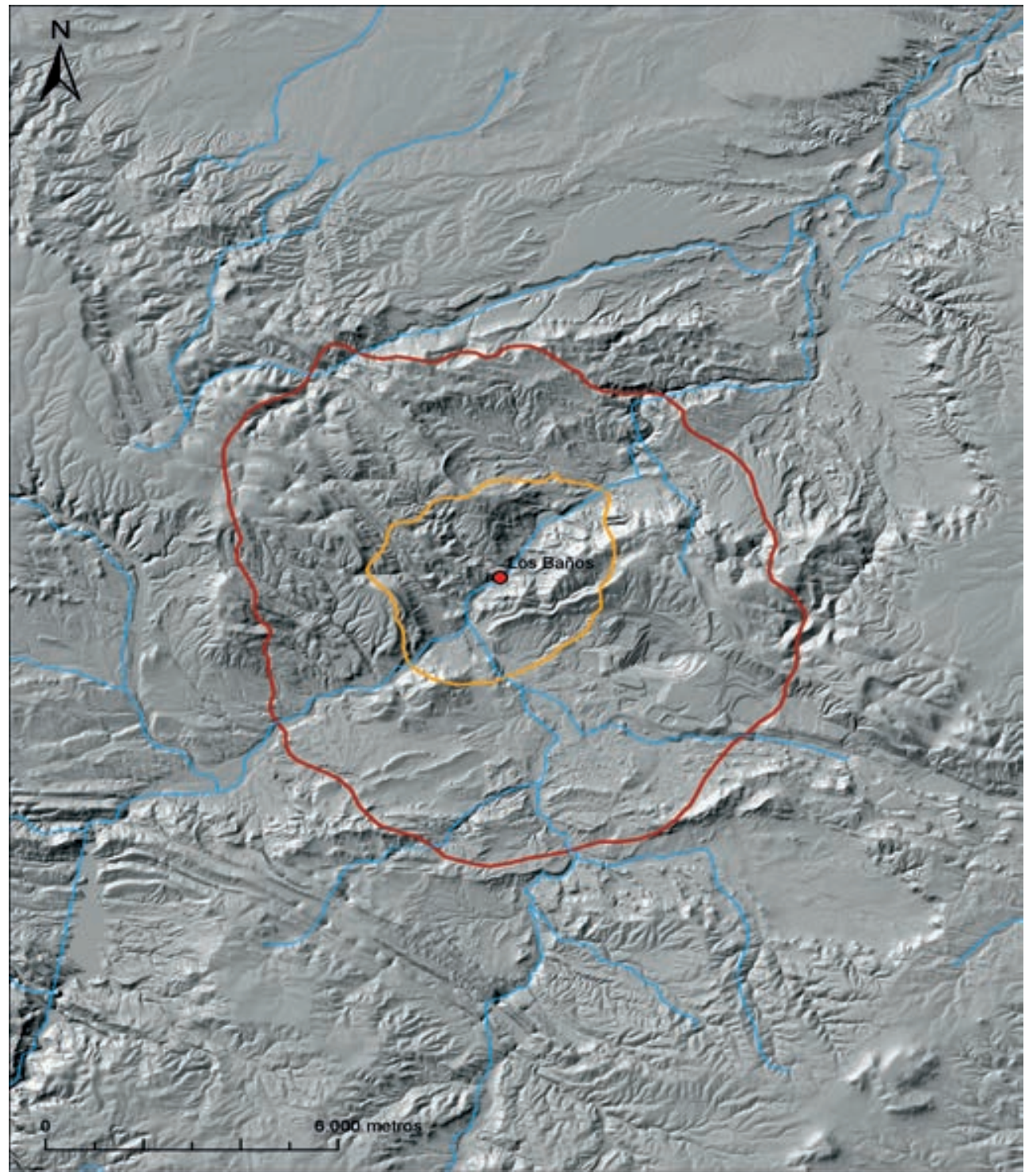

Figura 14. Territorios de explotación (isocronas de 1 y 2 h) en torno a Los Baños (Ariño, Teruel).

\begin{tabular}{|l|c|c|c|c|c|c|}
\hline & Cabezo Cruz & Baños & Costalena & Pontet & Secans & Botiquería \\
\hline Isocrona 1 h & 44,35 & 16,24 & 28,28 & 31,15 & 24,00 & 23,24 \\
Isocrona 2 h & 125,97 & 99,27 & 104,89 & 115,96 & 103,67 & 100,00 \\
\hline
\end{tabular}

Figura 15. Tabla comparativa con las extensiones en $\mathrm{km}^{2}$ de los territorios máximos para recorridos de 1 y 2 h desde el yacimiento.

que toma como referencia la fórmula de Naismith, en la que se estima la distancia recorrida desde un punto en un determinado intervalo temporal en función de la velocidad del desplazamiento en llano $(5 \mathrm{~km} / \mathrm{h})$ y de la pendiente del terreno (incremento de 1 ' por cada $10 \mathrm{~m}$ de desnivel). Los cálcu- los se han realizado de forma semiautomática con el programa ArcGis 9.3, a través del módulo Spatial Analyst. Se ha utilizando como base topográfica que determina la fricción y, por tanto, el coste en el desplazamiento, un mapa de pendientes generado desde un MDE (Modelo Digital 


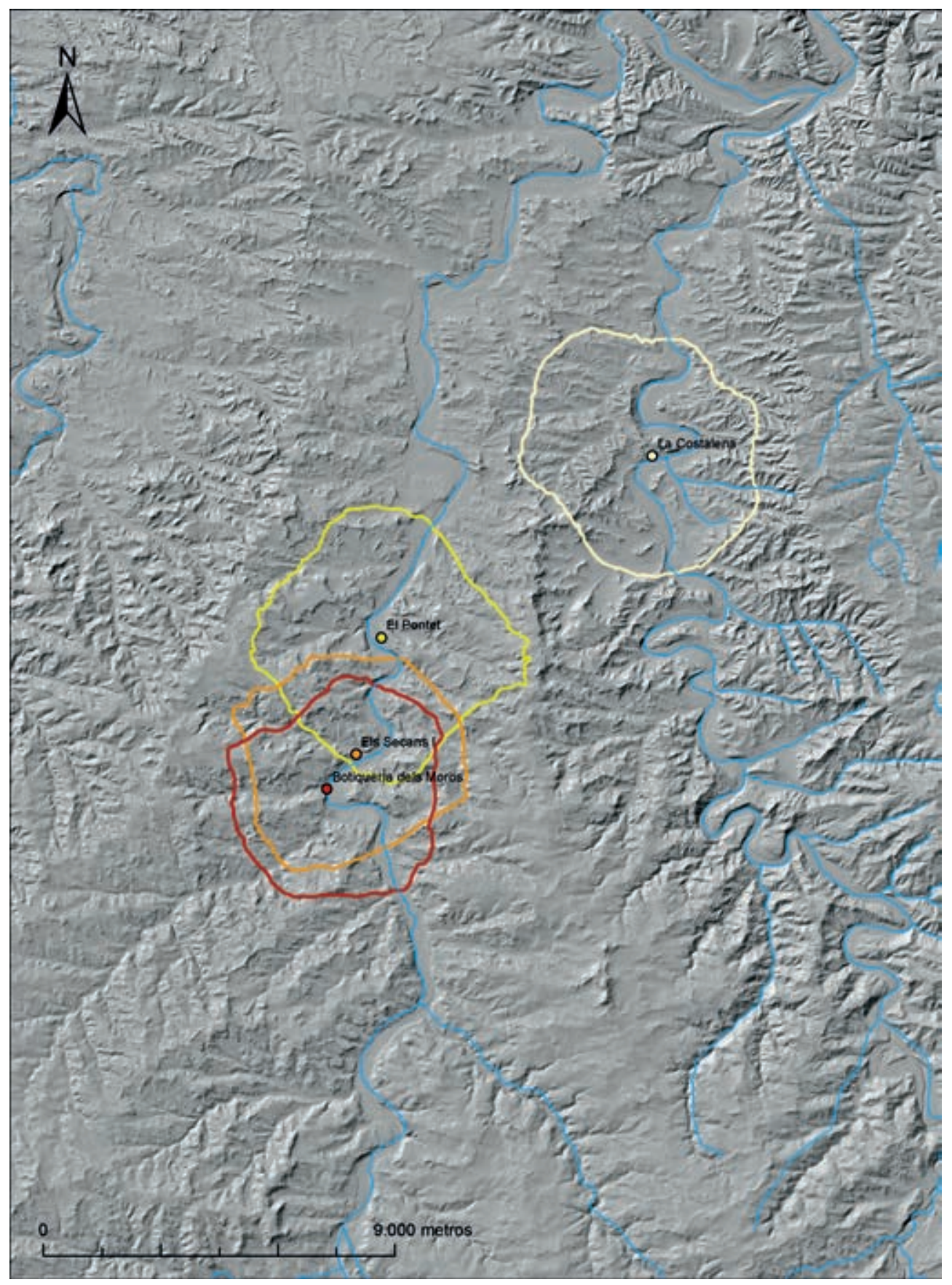

Figura 16. Territorios de captación con isocronas de 1 h en el valle del Matarraña.

de Elevaciones) calculado con una resolución de $10 \mathrm{~m} /$ pixel a partir del MTN a escala 1:25000.

Este procedimiento, excepto en lo concerniente a la aplicación informática, es el que hemos

1 Procedimiento realizado por Fernando Pérez-Lambán, a quien agradecemos su inestimable colaboración. venido empleando en el estudio de yacimientos mesolíticos y neolíticos aragoneses, siendo conscientes de los inconvenientes y dificultades planteados en trabajos que se remontan a una serie de conferencias entre 1987 y 1989, que por motivos editoriales vieron la luz casi diez años después (Rodanés 1996; Rodanés y Ramón 1995; Rodanés, Tilo y Ramón 1996; Rodanés y Picazo 


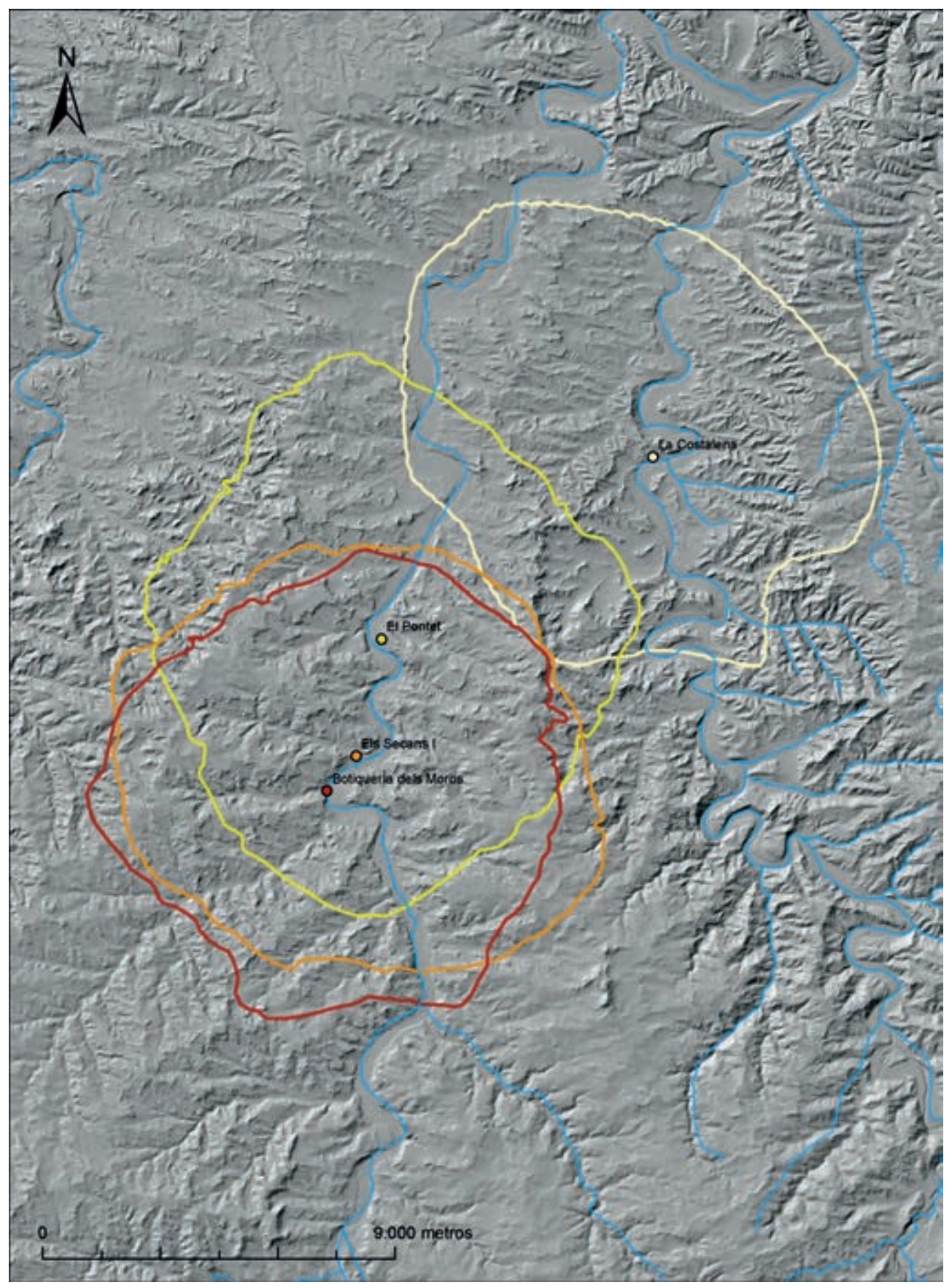

Figura 17. Territorios de captación con isocronas de 2 h en el valle del Matarraña.

2005). Hay que puntualizar - ya lo hemos hecho en otras ocasiones - que no buscamos establecer el área de influencia de cada yacimiento (site cachment), sino dibujar un posible espacio utilizado habitualmente. Partimos de la hipótesis de que las actividades económicas estarán gobernadas por la ley de la disminución de los ingresos con la distancia, concordando, con lo expuesto por la denominada «escuela paleoeconómica de Cambridge»: la lejanía dificulta la explotación (Rodanés y Ramón 1995).

En definitiva - por intentar ser más explícitos y en cierto modo justificar el porqué seguimos utilizando sin variaciones los presupuestos utilizados hace más de veinticinco años-, consideramos estas aproximaciones como un simple 
modelo icónico, utilizando el concepto de la arqueología analítica de Clarke (1984) sin pretender alcanzar el grado de análogo. Así lo han entendido igualmente otros autores en diferentes ensayos sobre asentamientos o arte rupestre en esta zona de estudio (Martínez Bea 2004a, 2004b).

El resultado obtenido en el Cabezo de la Cruz para recorridos de una y dos horas conforma dos isocronas concéntricas, más o menos circulares y bastante regulares (figs. 12 y 13). Ello es debido a que estamos en un valle simétrico con relieve relativamente uniforme, pues más allá de la existencia de sendas plataformas estructurales con laderas de cierta pendiente, no presenta anomalías significativas que incrementen los costes de desplazamiento y deformen las áreas potencialmente accesibles desde el yacimiento.

La extensión de los territorios estimados para desplazamientos máximos de 1 y 2 h, alcanzarían una superficie de $44,35 \mathrm{~km}^{2}$ y $125,97 \mathrm{~km}^{2}$, respectivamente. Si comparamos estos valores con los obtenidos por similar procedimiento en otros yacimientos del valle del Ebro como Los Baños, en el río Martín, o los conjuntos del valle del río Matarraña (Pontet, Secans, Botiquería y Costalena), observamos diferencias significativas que están relacionadas con las características del relieve, mucho más abrupto, en el que se encuentran estos últimos yacimientos (figs. 14-17).

Dentro de las áreas de accesibilidad potencial a una distancia de $1 \mathrm{~h}$ de marcha, el entorno más inmediato y, en apariencia, el de mayor interés, co- rresponde a la llanura aluvial del río Huerva, actualmente una franja de unos $7 \mathrm{~km}$ de longitud y una superficie de unos $4,6 \mathrm{~km}^{2}$, que estaría dominada por bosques galería con recursos diversificados tanto vegetales como animales y aportación estable de agua. La ubicación del yacimiento en este sector se explica de esta forma por la alta concentración de recursos que supone este entorno y el acceso relativamente fácil a los mismos (fig. 18).

Más allá de la llanura aluvial, el territorio teórico de captación dentro del círculo de 1 h se extiende por ambas márgenes del río Huerva, hasta alcanzar los límites de las plataformas estructurales miocenas de La Muela y la Plana de Jaulín. Se trata de unas áreas dominadas por glacis y terrazas cuaternarias que conforman terrenos llanos, alomados, surcados por barrancos de escasa entidad que descienden desde esas plataformas hacia el río. Es un relieve suave en el que dominan las litologías arcillosas con presencia de cantos y bloques entre los que destacan los abundantes riñones de sílex procedentes de las plataformas. El territorio de la margen derecha es algo más reducido, unos $13 \mathrm{~km}^{2}$, pero es de reseñar que, junto con el tramo aluvial, concentra la zona de control visual efectiva desde el asentamiento y, por tanto, podría tratarse de un sector de atención preferente por parte del grupo.

Dentro del ámbito de captación definido por las dos horas de marcha no se observan diferencias significativas. Entre los aspectos más relevantes está la inclusión de forma efectiva de los llanos elevados

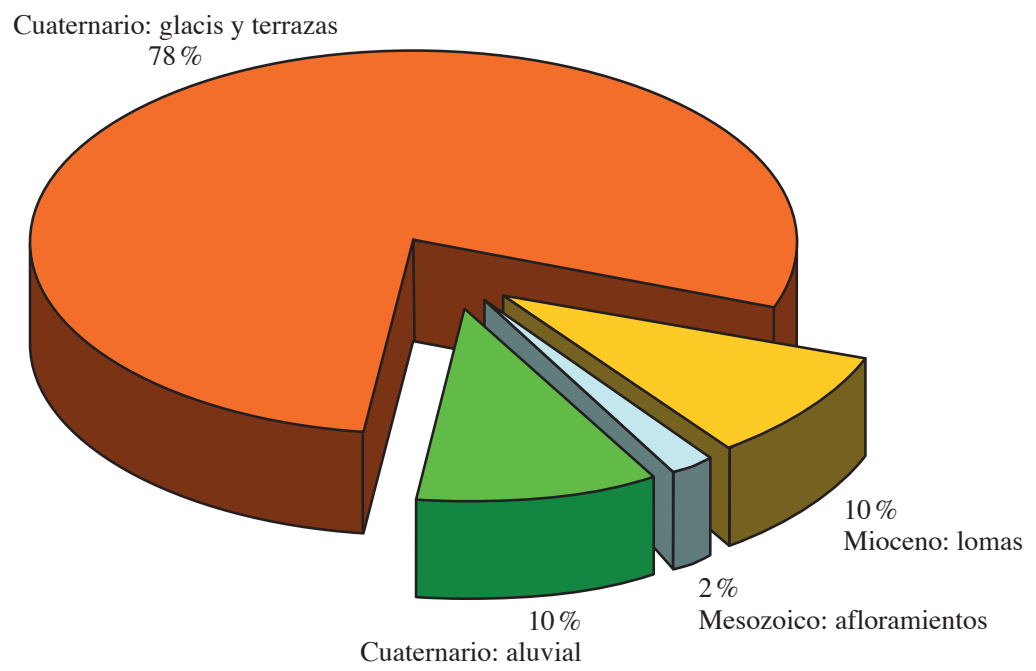

Figura 18. Distribución de los diferentes tipos de terreno dentro del ámbito definido por una hora de marcha desde el yacimiento. 
desarrollados sobre las plataformas estructurales miocenas y sus escarpes, con importantes afloramientos silíceos, y el alcance de los límites del dominio mesozoico hacia el sur, aguas arriba del río Huerva, por donde este circula entre elevados cortados calcáreos. Precisamente ese límite de las dos horas de marcha viene a coincidir con la irrupción de las potentes formaciones calcáreas jurásicas que marcan ese límite y que suponen un cambio muy marcado en la litología y orografía del terreno, configurando un paisaje diferente, con otras posibilidades en cuanto a la vegetación y fauna soportada $y$, desde luego, mucho más abrupto, debido al profundo encajamiento del río Huerva y la proliferación de crestas y cortados calcáreos.

Por último, señalar que, dentro de estos supuestos territorios teóricos de explotación, también se rastrean algunos yacimientos líticos de interés que parecen corresponder a dos categorías distintas:

1. Yacimientos con escasos restos líticos de aspecto mesolítico, sin cerámicas y sin otras piezas significativas, localizados en las inmediaciones del Cabezo de la Cruz.

2. Yacimientos con numerosos restos líticos, con alguna pieza significativa de cronología meso-neolítica y algún fragmento cerámico, localizados a más de una hora del Cabezo de la Cruz.

Los primeros yacimientos (181007_4, 241007_2, 191007_1) se han encontrado a menos de $1 \mathrm{~km}$ de la cabaña, al otro lado del río, en el glacis de la margen derecha. Los restos líticos están concentrados, pero son muy escasos y poco significativos: algunos fragmentos de laminitas, núcleos, alguna lasca, etc., que no difieren de los abundantes restos de desechos recuperados en la cabaña. No parece que estemos ante asentamientos de entidad, sino que, como ya se ha comentado, parecen corresponder a ocupaciones efímeras, producto de actividades puntuales de corta duración, como las relacionadas con la talla del sílex con las que se vinculan los pocos restos identificados. Desde esta perspectiva se podría plantear una hipotética relación con el Cabezo de la Cruz, entendiendo estos lugares como puntos de talla y aprovisionamiento de sílex, aprovechando los abundantes nódulos incorporados en los depósitos de glacis que tapizan toda esa zona.

Los segundos yacimientos (Muel I y La Cuesta del Herrero) se encuentran aguas arriba del río Huerva, en la misma margen izquierda, y a una distancia superior. Concretamente parecen situarse a intervalos relativamente regulares de 4,6 km y $5,2 \mathrm{~km}$, escapando sucesivamente de los territorios de 1 y $2 \mathrm{~h}$. Corresponden a hallazgos de mayor entidad, conjuntos líticos con varias decenas de piezas bastante dispersas entre las que se encuentra algún elemento significativo de tradición geométrica.

En el caso del paraje denominado Muel I (Muel), sobre una terraza de la margen izquierda del río Huerva, pudimos comprobar la existencia de un yacimiento con restos de talla de sílex, fundamentalmente lascas y un núcleo discoide, junto con un segmento con retoque en doble bisel, un posible microburil (fig. 19) y una pieza con retoque plano, materiales que, en principio, apuntan a una cronología neolítica.

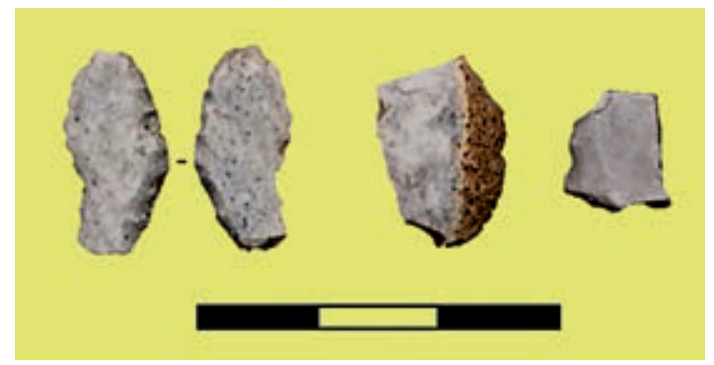

Figura 19. Materiales recuperados en Muel I: segmento con retoque en doble bisel, microburil y fragmento de geométrico.

El otro yacimiento se denomina La Cuesta del Herrero (Mezalocha), también situado junto al río Huerva, en un rellano de una ladera orientada al Sur. Los materiales son los habituales, lascas pequeñas, porciones de laminitas, algún núcleo y otros restos informes, además de un trapecio achaparrado con retoque abrupto. En una zona algo apartada del yacimiento también se recogieron varios fragmentos de cerámicas modeladas a mano.

Estos emplazamientos que van jalonando el río Huerva parecen tener mayor entidad y, tal vez, correspondan a asentamientos tipo Cabezo de la Cruz. Aunque no podemos sostener su sincronía, pues los escasísimos indicios materiales apuntan a una cronología ligeramente posterior ya neolítica, sí podemos asumir su correspondencia a una misma tradición de tipo geométrico y a similares poblaciones que en su permanente movilidad residencial van estableciendo sus campamentos en las zonas más favorables para un más fácil aprovechamiento de los recursos que el medio 
proporciona. Este modelo de ocupación del territorio, en última instancia, no diferiría de lo observado en otros ámbitos geográficos, caso del río Matarraña, pero eso sí, sustituyendo las ocupaciones en abrigo por asentamientos al aire libre.

\subsubsection{Visibilidad}

La cuenca visual ${ }^{2}$ controlada desde la cabaña del Cabezo de la Cruz es notablemente asimétrica y dirigida hacia el SE y el río Huerva, con un alcance efectivo que no va más allá de unos $3,5 \mathrm{~km}$ aguas arriba del río y $4 \mathrm{~km}$ aguas abajo. Esto es consecuencia de la ubicación de la cabaña al pie de un cerro, en una suave ladera con esa orientación SE. Este condicionante determina que todo el tramo situado al NO quede fuera de cualquier alcance visual. De esta forma, el mejor control y más inmediato se focaliza especialmente en el tramo del río Huerva que discurre junto al yacimiento, en una franja de unos $7 \mathrm{~km}$ de larga, aunque el control efectivo sería algo menor, y una anchura máxima inferior al kilómetro (fig. 20).

En este tramo del río confluyen una serie de barrancos de cierto interés pues pudieron marcar rutas transversales preferentes ${ }^{3}$ para los desplazamientos humanos o animales que complementarían las supuestas rutas N-S a lo largo del corredor del río Huerva. Aunque el control de esos

2 La cuenca visual se ha estimado mediante el programa ArcGis 9.3 que implementa el módulo 3D Analyst/Surface Analysis, opción Viewshed. La base topográfica para su cálculo han sido los MDT con resolución de $5 \mathrm{~m}$ /pixel del Instituto Geográfico Nacional editados de acuerdo con las hojas de MTN escala 1:25.000, accesibles en <http://centrodedescargas. cnig.es/CentroDescargas/index.jsp $>$.

3 La consideración de los cursos fluviales como vías naturales de paso no deja de plantear importantes problemas. Los estudios de reconstrucción paleoambiental realizados por F. Pérez Lambán para esta zona indican que los actuales barrancos, por los que discurre buena parte de la red de caminos locales, presentan una morfología de fondo plano y escasa vegetación que favorece la instalación y eficacia de esas vías. Sin embargo, esa morfología se produce, entre otras razones, por la acumulación de gran cantidad de sedimentos en épocas relativamente recientes que rellenan los antiguos cauces. Esos rellenos son consecuencia de los procesos erosivos que afectan a las partes altas y medias de las laderas, proceso que se inicia en el Neolítico (Peña et al. 2004). Por tanto, en el momento que nos ocupa, hacia mediados del Holoceno, los barrancos que discurren por las inmediaciones del Cabezo de la Cruz contarían con una forma más bien en $\mathrm{V}$ y una mayor profundidad. Asimismo, es de esperar que soportaran un mayor caudal hídrico y una vegetación más tupida debido a la mejor conservación de los suelos y a un entorno, en general, menos degradado. Por todo ello, en modo alguno pretendemos situar las vías de comunicación junto a los propios cauces o sus inmediaciones, sino que tendemos a entender esos cursos principales o secundarios como pasillos o corredores potenciales en torno a los cuales pudo configurarse la red de comunicaciones. barrancos no es efectivo, sí se alcanza a tener una buena visual de su desembocadura en el Huerva, como es el caso de los barrancos Salado y de la Torrubia por el SO, por donde se accedería con facilidad hacia el río Jalón y Sistema Ibérico. Asimismo, de especial relevancia es el control parcial (lomas inmediatas) del tramo final del barranco Vicario que discurre al E-NE, junto a cuya desembocadura se encuentra la ciudad celtibérica de Contrebia Belaiska, y del barranco de Las Lenas, que pudo funcionar como vía de comunicación transversal al río Huerva, facilitando las comunicaciones E-O y uniendo este valle con otros paralelos de la margen derecha del río Ebro, caso de los ríos Ginel, Aguasvivas, etc., configurando una ruta alternativa y más directa a la del Ebro para conectar esta comarca con los núcleos del Bajo Aragón, con bien documentadas poblaciones mesolíticas.

Más allá del río, al SE del yacimiento, también hay un buen control de la margen derecha del Huerva, un terreno llano, alomado, con suave buzamiento hacia el Oeste y surcado por algunos barrancos (fig. 21). Esta zona está ocupada por un extenso glacis que desciende desde la base de la Muela de Jaulín-San Borombón, plataforma estructural miocena que delimita el valle por este sector y cuyas estribaciones y escarpe superior representan el límite de la cuenca visual.

Dentro de este ámbito, controlado directa y efectivamente desde el yacimiento, se encuentran recursos de interés, como son los notables afloramientos silíceos con forma de nódulos arriñonados existentes entre las calizas miocenas de la referida muela, que también se incorporan entre los materiales detríticos del glacis, acercándolos hasta las proximidades del río Huerva.

De hecho, las prospecciones intensivas realizadas en ese glacis (Pérez, Fanlo y Picazo 2010) han permitido la detección de algunos conjuntos líticos poco significativos pero que cabría relacionar con la cabaña que estudiamos, pues los escasos restos líticos identificados entran dentro de lo que se puede esperar de un conjunto mesolítico. Así, por ejemplo, en el yacimiento denominado 181007_4 (Mozota), situado en un campo de almendros cerca del escarpe sobre el río Huerva, se cita un núcleo, un par de fragmentos de laminitas y alguna otra pieza poco significativa. Otro núcleo de laminitas se encontró en 241007_2 (Mozota) y nuevos fragmentos de pequeñas láminas en 191007_1 (Mozota). A falta de elementos ti- 


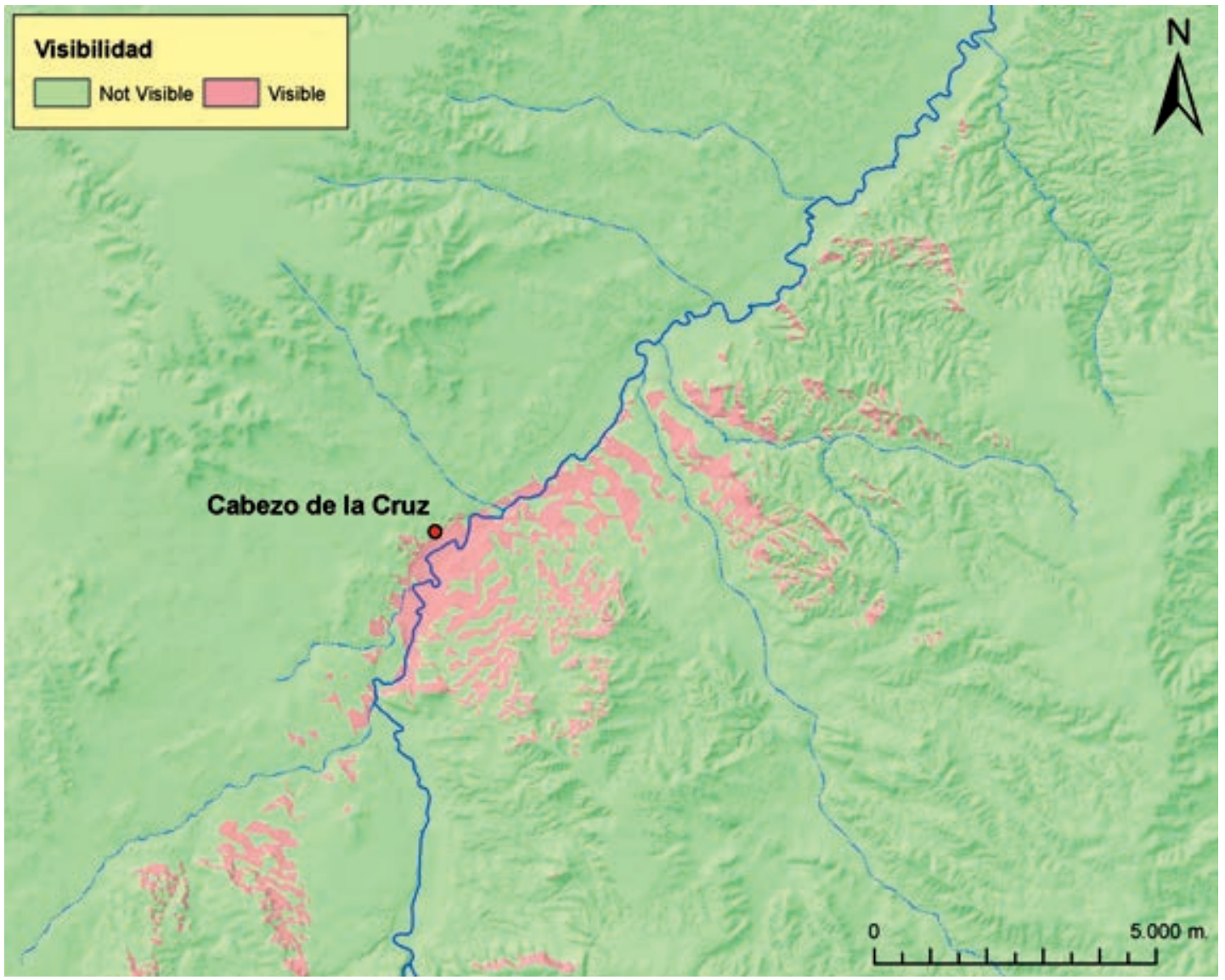

Figura 20. Cuenca visual calculada desde la cabaña mesolítica del Cabezo de la Cruz.

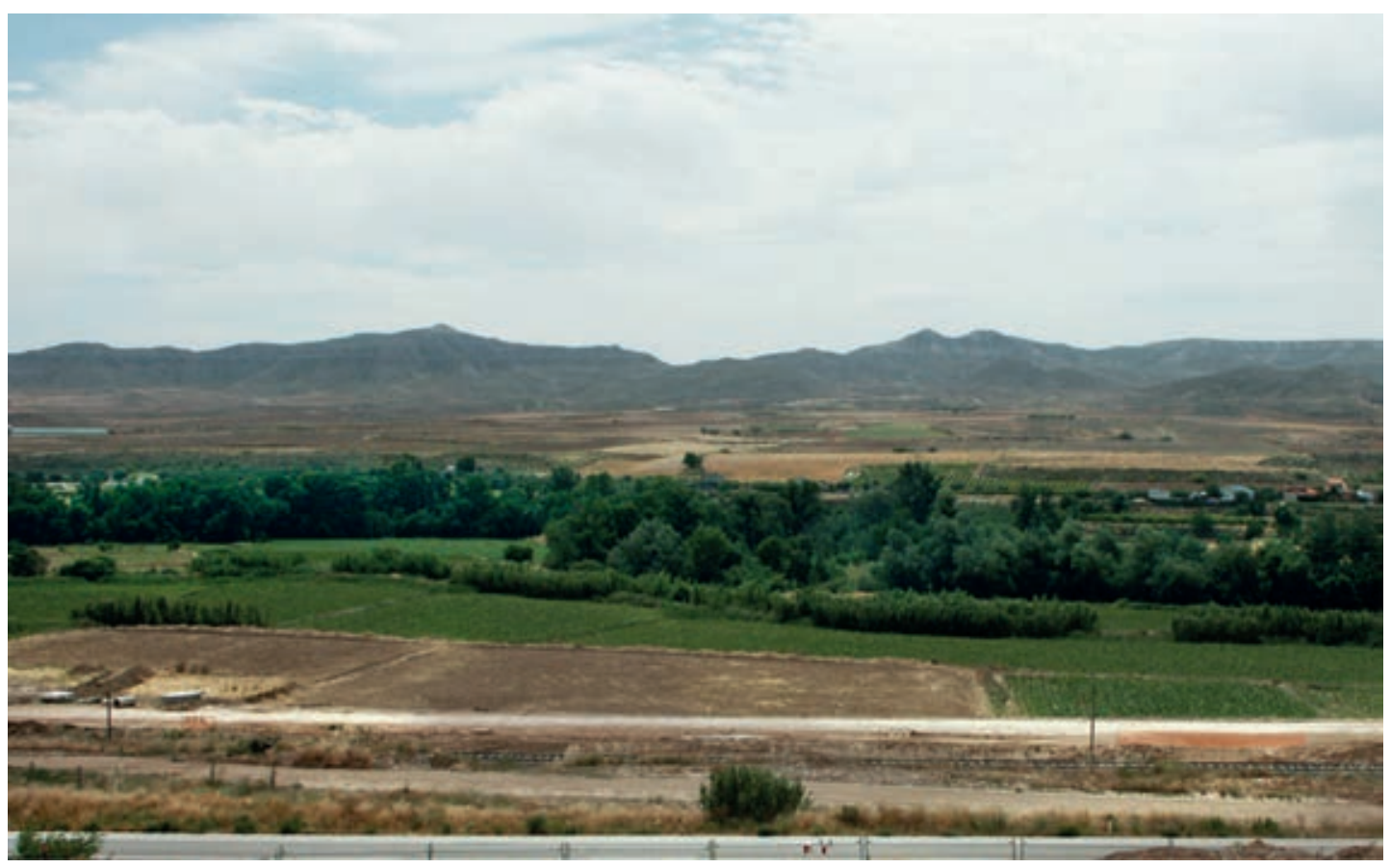

Figura 21. Vista desde el Cabezo de la Cruz hacia el SE. Cauce del río Huerva, glacis de la margen derecha y, al fondo, plataforma estructural miocena con sus estribaciones. 
pológicos más evidentes, estos materiales, que en ningún caso se asocian con cerámicas a mano y que guardan similitudes morfométricas con el tipo de laminitas documentadas en el Cabezo de la Cruz, bien podrían encuadrarse en esta etapa, configurar establecimientos efímeros antes que asentamientos de cierta duración y relacionarse con actividades vinculadas a la talla y aprovisionamiento de materias primas (fig. 22).
A estos lugares podemos añadir la Cueva de la Galocha, una de las pocas cavidades existentes en la zona. Se conforma como un gran abrigo abierto en un paquete de calizas jurásicas que conforman un cortado calcáreo de cierta potencia. Está orientada al Oeste y mantiene contacto visual directo con el Cabezo de la Cruz. La inspección de la cueva nos permitió detectar la existencia de una interesante acumulación estratigráfica de ori-

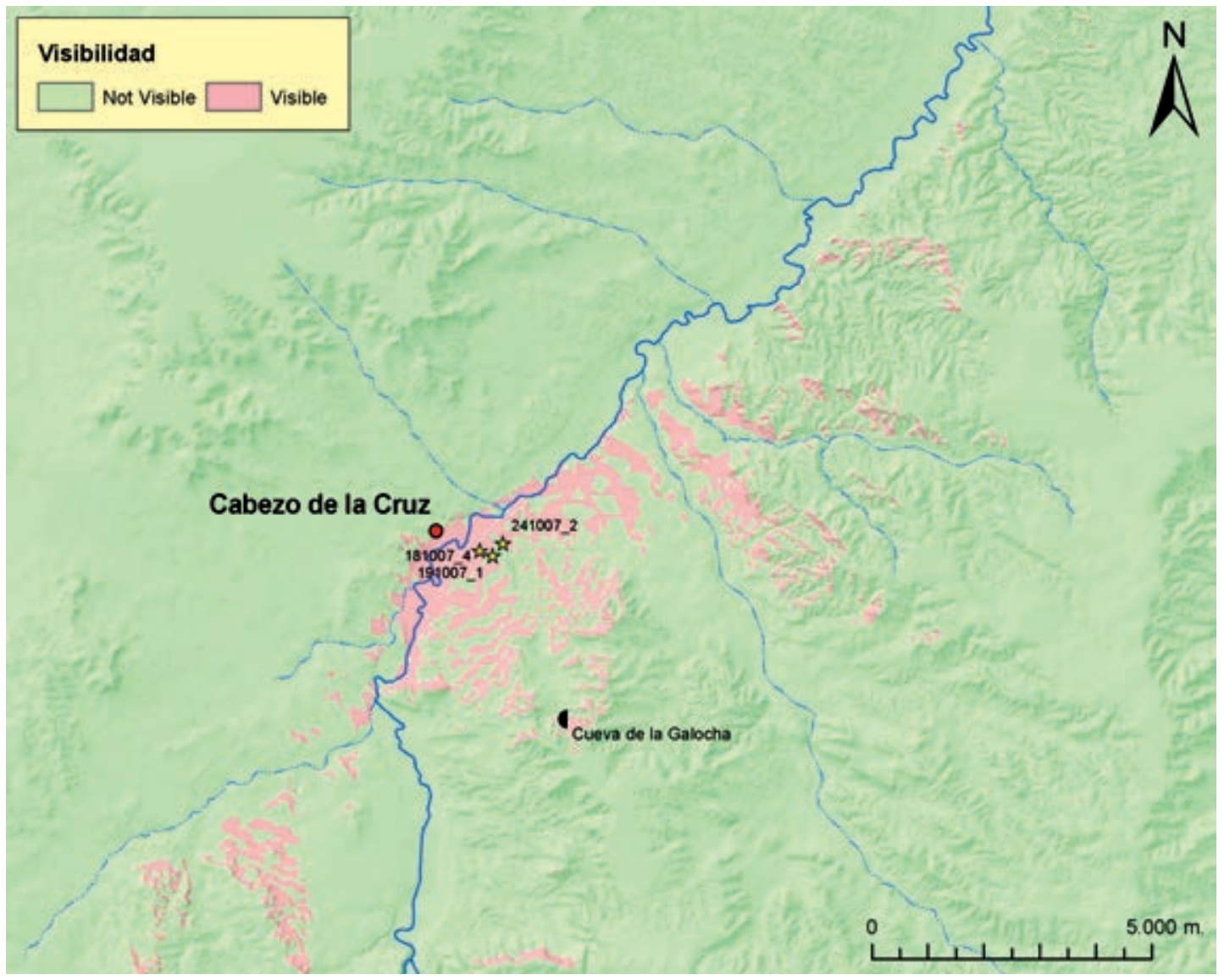

Figura 22. Cuenca visual calculada desde la cabaña mesolítica del Cabezo de la Cruz con algunos yacimientos situados en sus inmediaciones.

gen antrópico que incorporaba elementos líticos no significativos (lascas y fragmentos de lascas de sílex) y abundantes carboncillos, pero no ha sido posible establecer su filiación cronológica y su vinculación potencial con la cabaña y/o el campamento mesolítico.

Fuera del ámbito de control inmediato, la cuenca visual obtenida desde el yacimiento alcanza otros relieves considerablemente más alejados que representan crestas o laderas con orientación favorable hacia el yacimiento, ya sea hacia el E-NE, en las estribaciones de la Muela de María, o hacia el $\mathrm{S}-\mathrm{SO}$, alcanzando ciertas lomas miocenas destacadas aguas arriba del río Huerva. En cualquier caso, sobre estos sectores, a distancias entre 5 y 9-7 km, no llega a existir un control visual efectivo.

Este patrón de visibilidad no difiere en esencia del observado para otros yacimientos mesolíticos 
del valle del Ebro situados en abrigo. Concretamente, las cuencas visuales calculadas para los principales yacimientos de los ríos Matarraña y Algás (Pontet, Botiquería, Secans, Costalena) muestran un modelo muy similar, al margen de las peculiaridades orográficas de esta zona, que determina una cuenca mucho menor debido a un relieve más intrincado y a una menor altura del yacimiento sobre el río (fig. 23).
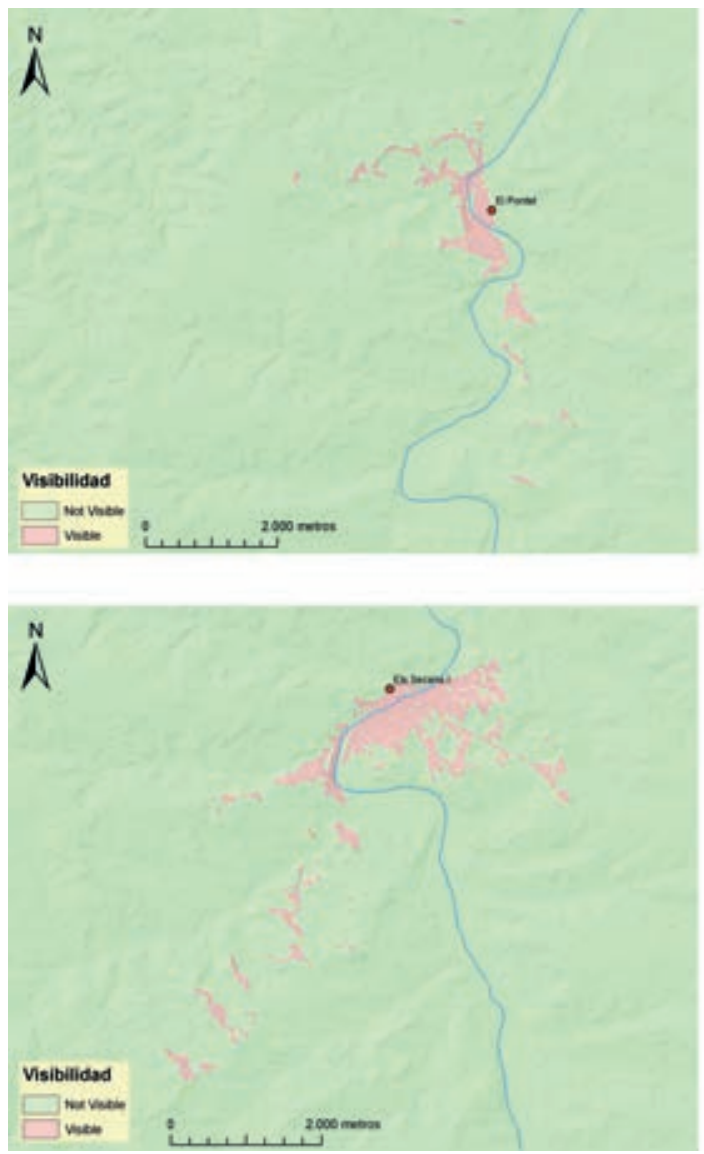

Figura 23. Cuencas visuales de los principales yacimientos del valle del río Matarraña: El Pontet, Botiquería dels Moros, Els Secans, Costalena.

cuenca visual recurrente tanto en abrigos como en asentamientos al aire libre como el que nos ocupa (fig. 24):

- Visibilidad direccional. Orientación variable con predominio de los campos visuales abiertos (ángulos obtusos) dirigidos hacia el cuadrante E-S como consecuencia de la orientación de los yacimientos y de su posición al abrigo de formaciones rocosas o laderas.
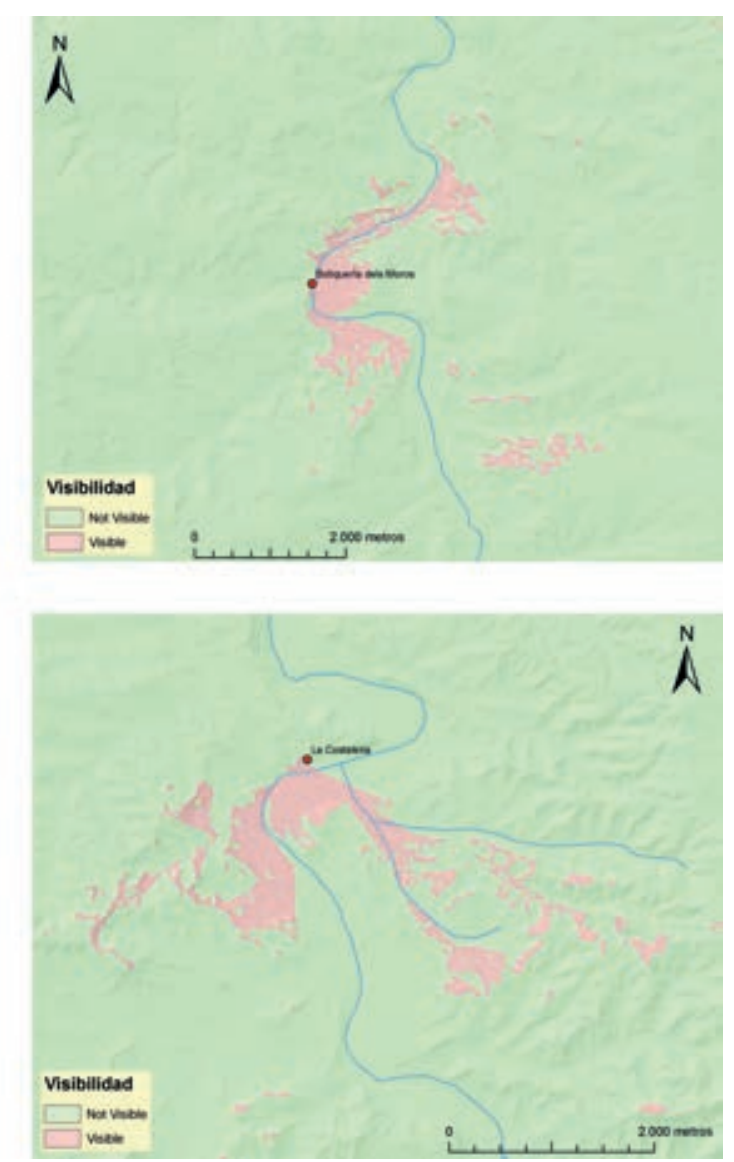

En cualquier caso, las similitudes son notables; especialmente parecida es la visibilidad obtenida desde el yacimiento de Els Secans, también con orientación dominante hacia el SE, centrada en un tramo del río Matarraña y un sector de su margen derecha.

A partir de estas coincidencias y a modo de tentativa por la escasa muestra sobre la que operamos, podríamos tratar de esbozar un modelo de 
- Visibilidad nula a espaldas de los yacimientos, normalmente hacia los sectores NO.

- Control parcial de los tramos finales de barrancos o cursos subsidiarios.

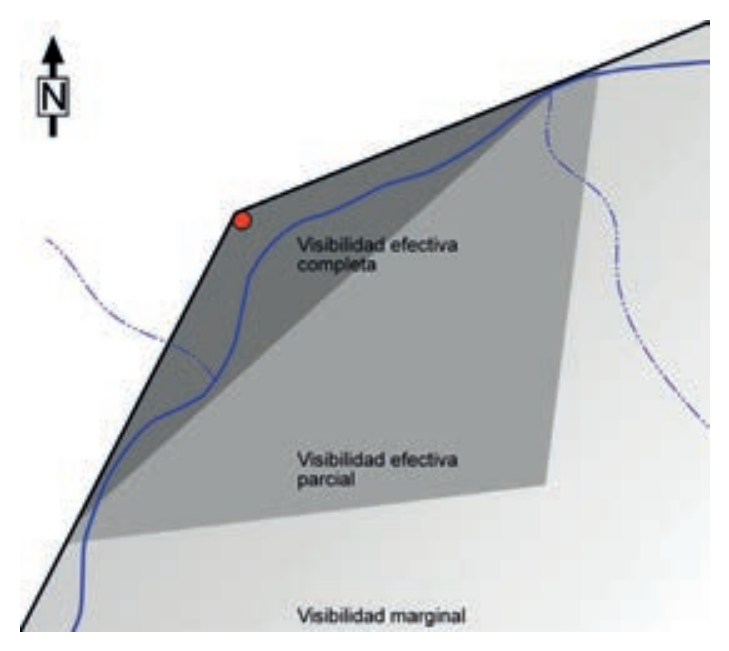

Figura 24. Esquema teórico del campo visual desde los emplazamientos mesolíticos.

\subsubsection{Hipótesis sobre la dinámica de poblamiento}

De los yacimientos de la margen derecha que incluimos en el estudio, los situados en el valle del Matarraña son los que proporcionan más información. El hecho de que los hábitats prolonguen en el tiempo y pertenezcan a una misma facies o, lo que es lo mismo, que tengan una identidad cultural similar permite generar una serie de hipótesis intentando dar respuesta al presumible aumento de población a lo largo de dos milenios, a las posibles interferencias entre ellos y, quizás, al control y distribución de los recursos naturales como hemos señalado en anteriores trabajos (Rodanés 1996; Rodanés y Ramón 1995; Rodanés y Picazo 2005; Rodanés, Tilo y Ramón 1996). Además de estos ensayos, cuyas conclusiones reiteramos con ciertos matices, el tema ha sido tratado por otros autores cuyas precisiones no dudamos en asumir (Cava 1994; Barandiarán y Cava 2002).

- La primera consideraría toda la red de asentamientos como un lugar temporal y cíclico, probablemente restringido a una estación climática, desde el que se producirían desplazamientos de todos los grupos a zonas geográficas más alejadas.

- La segunda posibilidad optaría por la adopción de un sistema rotatorio, de los diferentes núcleos - no necesariamente todos al mismo tiempo- durante períodos relativamente cortos, en los que se produciría el cambio de residencia, según se agotasen los recursos o cambiasen los condicionantes medioambientales, para volver una vez completado el ciclo dando tiempo a que se regenere el ecosistema, superando el cambio de estación o de otro tipo de condicionantes o motivos que provocasen el abandono temporal de los abrigos. Para valorar adecuadamente esta hipótesis, necesitaríamos conocer, al menos, la densidad de población que soportaría cada yacimiento, así como el volumen de alimentos que se obtendría de cada territorio y, en especial, el carácter y la causalidad de los ciclos migratorios.

- Una tercera opción supone la existencia de un hábitat permanente y constante EpipaleolíticoNeolítico en el conjunto del valle, lo que supondrá una mayor celeridad en el agotamiento de los recursos naturales, salvo que se encuentren fórmulas que sustituyan la caza y recolección intensiva, lo que se conseguiría o bien con cambios en la organización social, o con la adopción de determinados aspectos propios de una economía neolítica. No obstante, debemos volver a insistir que no todos los yacimientos poseen las mismas características de habitabilidad y de ocupación prolongada en el tiempo.

Estas son algunas reflexiones que pretendían explicar el proceso o la evolución del poblamiento en el valle del Matarraña. En el estado actual de las investigaciones pensamos que la primera hipótesis resulta más difícil de validar, mientras que las restantes pueden ser factibles, incluso complementarias, y generar un gran número de posibilidades intermedias. Así, son perfectamente asumibles los matices planteados por Barandiarán y Cava $(2002,308)$, cuyas propuestas a: que cada unidad de depósito (las que haya en el interior de cada nivel o estrato) se corresponde con un asentamiento temporal (coincidente con estaciones del año o no) en ese lugar y b: que se ha de reconocer, por tanto, que cada una de esas unidades de depósito debe articularse con (mejor que «depender de») otras dentro o fuera del propio Bajo Aragón. Estas pueden ser incorporadas a nuestra segunda hipótesis, mientras que la c (que, con los registros arqueológicos actuales, no somos capaces de definir cuál es el grado de interrelación entre los diferentes asentamientos del propio Bajo Aragón), en sentido estricto y siendo 
objetivos, sería una realidad innegable con los argumentos que nos proporcionan las actuales investigaciones. En este sentido son interesantes los resultados de los análisis de correspondencias dedicados a las piezas no retocadas de cada uno de los niveles de Costalena, Botiquería y Secans (Rodanés, Tilo y Ramón 1996, 49) que muestran una mayor afinidad entre los niveles de un mismo asentamiento independientemente de la cronología, que entre niveles con cronologías similares de los diferentes yacimientos. Esto podría significar una similar tradición en las técnicas de talla en cada uno de los abrigos, es decir, cierta identidad de cada uno de los conjuntos, lo que nos llevaría a proponer que cada yacimiento, en principio, se podría articular mejor con otros de fuera del valle.

Como sucede en Europa occidental es difícil asignar una posición precisa a los yacimientos en los circuitos de nomadismo, en especial a los lugares de pequeñas dimensiones. Los grandes lugares del Tardenoisiense podrían hacer pensar en ocupaciones permanentes con una movilidad más restringida. En el caso de los lugares más cercanos a los ríos hay tres interpretaciones: lugares de ocupación estacional durante muchos años, campos de agregación periódicos de varias comunidades o lugares ocupados largamente utilizados que sirven de base a expediciones logísticas (Ghesquière y Marchand 2010, 44). Interpretaciones, por otra parte, muy similares o parecidas a las esbozadas en publicaciones antes citadas

La reducción de distancias de aprovisionamiento y la economía de amplio espectro permiten la adaptación a diferentes ecosistemas. No podemos seguir manteniendo la imagen de pequeños grupos nómadas al límite de la supervivencia y con técnicas rudimentarias. Esta visión procede, más bien, de la experiencia del estudio de las últimas sociedades cazadoras recolectoras que ocupan en la actualidad o más bien durante el siglo XX unos espacios marginales y están en vías de extinción.

\subsubsection{Sobre demografía}

El componente demográfico es difícil de estimar. Los cálculos son siempre problemáticos. Sirva este ejercicio como elemento ilustrativo de las diversas propuestas y su dificultad de traslación a la prehistoria Para esta época, esencialmente durante el atlántico, contamos con los clásicos ensayos de Rozoy que, para territorio francés, estima una densidad de población de un habitante por cada $10 \mathrm{~km}^{2}$ o 10 por $100 \mathrm{~km}^{2}$. Bordes estimaba una posible población para el Magdaleniense superior de algunas decenas de miles de individuos, quizás entre 10 y 15 000, más concentrados que durante el Epipaleolítico, donde pudo aumentar la población a unos 50000 que estima Rozoy (1978, 1105-1107).

En una reciente síntesis se aborda el problema de las poblaciones y se retoman las propuestas clásicas de varios autores basadas en analogías etnográficas (Ghesquière y Marchand 2010, 85 y 86). Rozoy calculaba una población mundial entre 5 y 10 millones de habitantes, mientras que Binford la situaba entorno a los 7 millones. La densidad propuesta por Rozoy - que ha cambiado de índices en varios trabajos - se sitúa en 0,06 habitantes por kilómetro cuadrado mientras que Testart propone un índice de 0,38. Los testimonios etnográficos de pueblos indígenas de Norteamérica varían entre poblaciones que ocupan territorios semidesérticos con densidades de 0,1 o 0,2 frente a las zonas más propicias de 0,5 a 2 . Todo ello nos lleva a ser muy escépticos en la cuantificación de la población dados los amplios márgenes entre los distintos índices. No obstante, nos vamos a permitir una aproximación en una zona conocida como es la cuenca del Matarraña. Actualmente, este valle junto al Algás se incluye en las comarcas de Matarraña y Bajo AragónCaspe. Entre ambas ocupan una extensión cercana a los $2.000 \mathrm{~km}^{2}$ (Matarraña 926,06 y Bajo Aragón-Caspe 997,3). Si tenemos en cuenta algunos índices mencionados, podríamos estimar una población que oscilaría entre 200 habitantes con la primera propuesta de Rozoy, mientras que, si aplicamos otras posteriores, nos situaríamos en unos 120 habitantes, frente a 760 si tomamos los índices de Testart. Podríamos variar el número de habitantes según estos índices u otros propuestos ya que los modelos dependen esencialmente de analogías con pueblos americanos y fluctúan de acuerdo con el tipo de ecosistema en el que se encuentran.

Si optamos por un cálculo en el que tenemos en cuenta el tipo de vivienda y sus dimensiones, debemos tener en cuenta otros parámetros. Para cabañas de las dimensiones de las descubiertas en el Cabezo de la Cruz se puede establecer una estimación de 5 personas para $10 \mathrm{~m}^{2}$, a partir de las excavaciones de Pincevent (Leroi-Gourhan y Brézillon 1972), lo que nos mostraría la posible existencia de un campamento de unas 15 a 20 per- 
sonas teniendo en cuenta que podemos contemplar la posible existencia de tres o cuatro cabañas, a tenor de los restos aparecidos y comentados en páginas anteriores.

Independientemente de las hipótesis planteadas a lo largo de estas páginas o de la validez de las mismas, el descubrimiento del yacimiento del Cabezo de la Cruz y su excavación ha contribuido sin ningún género de dudas a un mejor conocimiento del Mesolítico geométrico en el valle del Ebro. Aspectos de subsistencia, economía, vida cotidiana o simbolismo no se han abordado en esta obra ya que en la mayoría de ellos el yacimiento ha sido parco en información por lo que necesariamente deberíamos remitirnos a repetir o «reactualizar» planteamientos expuestos en diferentes síntesis, extremo este que consideramos innecesario ante la numerosa y reciente bibliografía que hemos señalado en los diferentes capítulos y apartados de este texto. Como indica el enunciado de este último capítulo, no hemos pretendido realizar una síntesis sobre el Mesolítico geométrico en el valle del Ebro, ni tan siquiera en el Bajo Aragón, sino más bien contextualizar este singular hallazgo.

\section{BIBLIOGRAFÍA}

AldAY, A. (ed.) 2006: El Mesolítico de muescas y denticulados en la cuenca del Ebro y el litoral mediterráneo peninsular. Memorias de yacimientos alaveses. Diputación Foral de Álava. Vitoria.

Alday, A. y CAVA, A. 2009: «El Mesolítico geométrico en Vasconia». En Utrilla, P. y Montes L. (eds.): El Mesolítico Geométrico en la Península Ibérica, Monografías Arqueológicas 44, Universidad de Zaragoza, 93-130.

ÁlVAREZ FERNÁNDEZ, E. 2006: Los objetos de adorno-colgantes del Paleolítico Superior y del Mesolítico en la Cornisa Cantábrica y en el valle del Ebro: una visión europea. Colección VITOR. Universidad de Salamanca.

ÁlVArez GraCIA, A. 1985: «Talleres de sílex de las áreas de los ríos Guadalope y Regallo». Bajo Aragón, Prehistoria, V, 87-103.

Álvarez Gracia, A. y Mostalac Carrillo, A. 1997: «Informe sobre las excavaciones arqueológicas en el antiguo Instituto de Bachillerato Mixto 4, Plaza de San Pedro Nolasco - San Vicente Paúl. Zaragoza». Arqueología Aragonesa 1994, Zaragoza, 249-259.
ARMENDÁRIZ, J. 1991: «Avance al estudio arqueológico de la cuenca media-baja del río Arga (Navarra): prospecciones». Cuadernos de Sección. Prehistoria y Arqueología, 4, 41-59.

ARMENDÁRIZ, J. e IRIGARAY, S. 1991: «Aportación al estudio de los yacimientos líticos postpaleolíticos al aire libre en Navarra». Zephyrus, XLIV-XLV: 223-239.

BALDELlOU, V. y UTRILlA, P. 1999: «Le Néolithique en Aragón». XXIVe Congrès Préhistorique de France: Les Civilisations Méditerranéennes, Carcassonne 1994, SPF, 275-290.

BARANDIARÁN, I. 1976: «Botiquería dels Moros (Teruel). Primera fechación absoluta del complejo geométrico del epipaleolítico mediterráneo español». Zephyrus, XXVI-XXVII: 183-186.

—, 1978: «El abrigo de la Botiquería dels Moros, Mazaleón (Teruel). Excavaciones arqueológicas de 1974». Cuadernos de Prehistoria y Arqueología Castellonense, 5: 49-138.

—, 2009: «El Mesolítico Geométrico en el espacio nororiental de la Península Ibérica: el progreso de su conocimiento». El Mesolítico Geométrico en la Península Ibérica, Monografías Arqueológicas 44, Universidad de Zaragoza, 13-31.

BARANDIARÁN, I. y CAVA, A. 1981a: «Epipaleolítico y Neolítico en el abrigo de Costalena (Bajo Aragón)». Bajo Aragón Prehistoria, III: 5-20.

—, 1981b: «Neolítico y Eneolítico en las provincias de Teruel y Zaragoza». I Reunión de Prehistoria Aragonesa. Huesca, 91-112.

—, 1985: «Las industrias líticas del Epipaleolítico y del Neolítico en el Bajo Aragón». Bajo Aragón Prehistoria, V: 49-86.

—, 1989: La ocupación prehistórica del abrigo de Costalena (Maella, Zaragoza). Arqueología y Paleontología, 6. Diputación General de Aragón. Zaragoza.

—, 1992: «Caracteres industriales del Epipaleolítico y Neolítico en Aragón. Su referencia a los yacimientos levantinos». En Utrilla, P. (coord.): Aragón/Litoral mediterráneo: intercambios culturales durante la Prehistoria. Institución Fernando el Católico. Zaragoza, 181-196.

—, 2001: Cazadores-recolectores en el Pirineo navarro. El sitio de Aizpea entre 8000 y 6000 años antes de ahora. Veleia, anejos serie Maior 10, Universidad del País Vasco. Vitoria. 
BARANDIARÁN, I. y CAVA, A. 2002: «A propósito de unas fechas del Bajo Aragón: reflexiones sobre el Mesolítico y Neolítico en la Cuenca del Ebro». SPAL, 9: 293-326.

Barandiarán, I. y VAllespí, E. 1980: Prehistoria de Navarra. Pamplona.

BARrios, I. y PÉREZ ARRONDO, C. 1986: Yacimientos líticos de superficie en el valle del río Cárdenas (La Rija). Nuevas aportaciones a las industrias postpaleolíticas en la Cuenca del Ebro. IER. Serie Historia 5. Logroño.

BARrios, I. y PORRES, F. 2006: «Poblamiento prehistórico en la zona noroccidental de La Rioja durante el Holoceno». Saldvie, 6: 59-94.

BEGUiRISTAIN, M.A. 1982: «Los yacimientos de habitación durante el Neolítico y Edad del Bronce en el alto valle del Ebro». Trabajos de Arqueología Navarra, 3: 59-156.

Benavente Serrano, J.A., Navarro, C., Ponz, J.L. y VILLANUEVA, J.C. 1991: «El poblamiento antiguo del área endorreica de Alcañiz (Teruel)». Al-Qannis, 2: 36-92.

BLANCO, A. 1988: «El poblamiento prehistórico en el término municipal de Maella». Cuadernos de Estudios Caspolinos, XIV: 145-160.

BORDES, F. y GAUSSEN, J. 1970: «Un fond de tente magdalénien près de Mussidan (dord.)». Mélanges Rust (Frühe Menschheit und Umwelt, t. 1. Archäologische Beiträge), 312-322.

Bordes, F., Rigaud, J. Ph. y SonnevilleBORDES, D. 1972: «Des buts, problèmes et limites de l'archéologie paléolithique». Quaternaria, XVI: 15-34.

Burillo Mozota, F. (ed.) 1993: Patrimonio Histórico de Aragón. Inventario Arqueológico. Daroca, Diputación General de Aragón. Zaragoza.

CAVA, A. 1986: Las industrias del Epipaleolítico al Neolítico en la cuenca del Ebro. Estudio tipológico. Tesis doctoral. Resumen. UPV.

—, 1987: «La industria lítica de la Prehistoria reciente en la cuenca del Ebro». Boletín del Museo de Zaragoza, 5: 5-72.

-, 1994: «El Mesolítico en la Cuenca del Ebro: un estado de la cuestión». Zephyrus, 47: 65-91.

-, 2001: «La industria lítica». En Barandiarán, I. y Cava, A.: Cazadores-recolectores en el Pirineo navarro. El sitio de Aizpea entre 8000 y 6000 años antes de ahora. Universidad del País Vasco. Vitoria, 63-147.
CAVA, A. 2004: «Los "procesos culturales" del comienzo del Holoceno en la Cuenca del Ebro y su contextualización». Saldvie, 4: 17-40.

Clarke, D.L. 1984: Arqueología Analítica. Segunda edición. Bellaterra. Barcelona.

DAVIDSON, I. y BAILEY, G.N. 1984: «Los yacimientos, sus territorios de explotación y la topografía». Boletín del Museo Arqueológico Nacional, II: 25-46.

Davis, B.A.S. y Stevenson, A.C. 2007: «The $8.2 \mathrm{ka}$ event and Early-Mid Holocene forests, fires and flooding in the Central Ebro Desert, NE Spain». Quaternary Science Reviews, 26: 16951712.

Domingo, R., BeA, M. y Utrilla, P. 2010: «Una nueva ocupación neolítica en el río Guadalope: la campaña de 2009 en el abrigo de Ángel 2». Saldvie, 10: 225-236.

FORTEA, J. 1973: Los complejos microlaminares y geométricos del Epipaleolítico mediterráneo español. Salamanca.

GARCÍA PuCHOL, O. 2005: El proceso de neolitización en la fachada mediterránea de la península Ibérica. Tecnología y tipología de la piedra tallada. BAR International Series 1430.

GARcía Puchol, O. y AurA, E. (coords.) 2006: El abric de la Falguera (Alcoi, Alacant). 8000 años de ocupación humana en la cabecera del río de Alcoy. Diputación de Alicante. Alicante.

GHESQUiÈre, E. y MARCHAND, G. 2010: Le Mésolithique en France. Archéologie des derniers chasseurs-cueilleurs. París.

GONZÁLEZ-SAMPÉRIZ, P. 2004a: Evolución paleoambiental del sector central de la Cuenca del Ebro durante el Pleistoceno Superior y el Holoceno. Instituto de Ecología Pirenaico. CSIC/Universidad de Zaragoza. Zaragoza.

—, 2004b: «Análisis Palinológico». En Utrilla, P. y Rodanés, J.M. (eds.): Un asentamiento epipaleolítico en el valle del río Martín. El abrigo de los Baños (Ariño, Teruel). Monografías Arqueológicas, 39: 59-62. Zaragoza.

GONZÁleZ-SAMPÉriz, P., Utrilla, P., MAZO, C., VAlero-GARCÉs, B., Sopena, M.C., Morellón, M., Sebastián, M., Moreno, A. y Martínez BEA, M. 2009: «Patterns of human occupation during the Early Holocene in the central Ebro basin (NE Spain): A response to the 8200-yr climatic event». Quaternary Research, 71: 127-132. 
JOVER, F.J. 2011: «El instrumental lítico tallado de Benàmer: continuidad y ruptura en los procesos de producción lítica tallada entre el VII y el IV milenio cal. BC». En Torregrosa P., Jover F.J. y López Seguí, E. (dirs.): Benàmer (Muro d'Alcoi, Alicante). Mesolíticos y Neolíticos en las tierras meridionales valencianas. SIP, Trabajos varios 112, 133-201.

LANZARote SubíAs, P., RAMÓN FERnÁNDEZ, N. y REY LANASPA, J. 1991: La Prehistoria Reciente en las Cinco Villas: del Neolítico a la Edad del Bronce. Centro de Estudios de Las Cinco VillasInstitución Fernando el Católico. Zaragoza.

LEORZA, R. 2004: «Estudio de las Materias primas líticas». En Utrilla, P. y Rodanés, J.M. (eds.): Un asentamiento epipaleolítico en el valle del río Martín. El abrigo de Los Baños (Ariño, Teruel). Monografías arqueológicas 39. Universidad de Zaragoza, 51-58.

Leroi-Gourhan, A. y Brézillon, A. 1972: Fouilles de Pincevent. Essai d'analyse ethnographique d'un habitat magdalénien. VII supplément à G.P. CNRS. París.

LÓPEZ GARCíA, P. 1992: «Análisis polínicos de cuatro yacimientos arqueológicos situados en el Bajo Aragón». Aragón/Litoral Mediterráneo. Intercambios culturales durante la Prehistoria. Institución Fernando el Católico. Zaragoza, 235-242.

LÓPEZ GARCÍA, P., y LÓPEZ SÁEZ, J.A. 1996: «Análisis paleopalinológico del yacimiento de El Secans: dinámica de la vegetación durante el Cuaternario». En Rodanés, J.M., Tilo, M.A. y Ramón, N. (coords.): El abrigo de Els Secans (Mazaleón, Teruel). La ocupación del valle del Matarraña durante el Mesolítico y Neolítico antiguo, AlQannis, 6: 84-95.

-, 2000: «Le paysage et la phase épipaléolithique-mésolithique dans les Pre-Pyrénées aragonaises et le bassin moyen de l'Ebre à partir de l'analyse palynologique». En Les derniers chasseurs-cueilleurs d'Europe occidentale (13.0005.5000 av J.C.). Actes du colloque international de Besançon, Annales Littéraires 699: 59-69.

LÓPEZ GARCíA, P., LÓPEZ SÁEZ, J.A. y SÁNCHEZ, J.J. 1991: «Análisis polínico del yacimiento de Botiquería (Mazaleón, Teruel)». Trabajos de Prehistoria, 48: 395-403.

LÓPEZ QUINTANA, J.C. 1996: «Definición y articulación del depósito estratigráfico de Pareko Landa (Sollube, Bizkaia) según la estratigrafía analítica». Krei, 1: 57-67.
LÓPEZ QuinTANA, J.C. y AGUIRRE, M. 1997: «Patrones de asentamiento en el Neolítico del litoral vizcaíno». En A. Rodríguez Casal (ed.): O Neolítico atlántico e as orixes do megalitismo. Santiago de Compostela, 335-352.

LÓPEZ SÁEZ, J.A., LóPez GARcía, P. y LÓPEZ MERINO, L. 2006: «La transición mesolítico-neolítico en el valle medio del Ebro y en el prepirineo aragonés desde una perspectiva paleoambiental: dinámica de la antropización y origen de la agricultura». Revista Iberoamericana de Historia, 1: 4-11.

Llanos, A. (ed.) 1987: Carta Arqueológica de Álava. Vitoria.

Martí, B., Aura, J.E., JuAn Cabanilles, J., GARcía PuChOL, O. y FernÁndez, J. 2009: «El Mesolítico de tipo "Cocina” en el País Valenciano». En Utrilla, P. y Montes L. (eds.): El Mesolítico Geométrico en la Península Ibérica. Monografías Arqueológicas 44. Universidad de Zaragoza, 205-258.

MARTíneZ BEA, M. 2004a: «Hábitat y territorio». En Utrilla, P. y Rodanés, J.M. (eds.). Un asentamiento epipaleolítico en el valle del río Martín. El abrigo de Los Baños (Ariño, Teruel). Monografías arqueológicas 39. Universidad de Zaragoza, 75-90.

—, 2004b: «La estación del Barranco Hondo en su espacio geográfico y social». En Utrilla P. y Villaverde, V. (eds.): Los grabados levantinos del Barranco Hondo (Castellote, Teruel). Gobierno de Aragón, 87-104.

MAzo, C. y MonTES, L. 1992: «La transición Epipaleolítico-Neolítico antiguo en el abrigo de El Pontet (Maella, Zaragoza)». En Utrilla, P. (coord.): Aragón/Litoral mediterráneo: intercambios culturales durante la Prehistoria. Institución Fernando el Católico. Zaragoza, 243-254.

Mazo, C., Montes, L., RodAnÉs, J.M. y UTRILLA, P. 1987: Guía arqueológica del valle de Matarraña. Colección Guías Arqueológicas de Aragón. DGA. Zaragoza.

Peña Monné, J.L., Julián, A., Chueca, J., ECHEVERRÍA, M.T. y Ángeles, G.R., 2004: «Etapas de evolución holocena en el valle del río Huerva: Geomorfología y Geoarqueología». En Peña, J.L., Longares, L.A. y Sánchez, M. (eds.): Geografía física de Aragón. Aspectos generales y temáticos. Universidad de Zaragoza e Institución Fernando el Católico. Zaragoza, 289-302. 
PÉrez Lambán, F., FAnlo Loras, J. y PicAzo MiLLÁN, J.V. 2010: «El poblamiento antiguo en el valle del río Huerva. Resultados de las campañas de prospección de 2007-2009». Saldvie, 10: 285-316.

PiCAZo Millán, J.V. 1986: El Eneolítico y los inicios de la Edad del Bronce en el Sistema Ibérico Central (Jiloca Medio y Campo Romanos). Monografías Arqueológicas del SAET, 1. Teruel.

—, 1993: «Del Paleolítico al Eneolítico». En Burillo Mozota, F. (ed.): Patrimonio Histórico de Aragón. Inventario Arqueológico. Daroca, Diputación General de Aragón. Zaragoza, 69-72.

PiCAZO Millán, J.V. y Loscos PASTOR, R. 2003 2004: «El poblamiento prehistórico en el curso medio del río Martín: prospecciones arqueológicas en el término de Obón (Teruel)». Kalathos, 22-23: $17-52$.

PICAZO, J. y RoDANÉS, J.M. 2008: «Talleres de sílex, poblados y aldeas. Una cabaña mesolítica en el Cabezo de la Cruz (La Muela, Zaragoza)». En Hernández, M.S., Soler, A. y López, J.A. (coords.): IV Congreso del Neolítico Peninsular. Alicante, 137-142.

RODANÉS, J.M. 1991: «El poblamiento prerromano del valle del Iregua. Estado actual de las investigaciones». Estrato, 3: 4-8.

—, 1996: «La economía prehistórica en Aragón». Historia de Aragón, vol. 2, 1989 (Economía y sociedad), Institución Fernando el Católico. Zaragoza, 23-40.

RODANÉS, J.M. y PASCUAL, H. 1982: «El yacimiento postpaleolítico al aire libre de La Dehesa de Navarrete (La Rioja)». Cuadernos de Investigación. Historia, VIII: 3-32.

RODANÉS, J.M. y RAMÓN, N. 1995: «El Neolítico antiguo en Aragón. Hábitat y territorio». Zephyrus: Revista de prehistoria y arqueología, 48: 101-128.

RodAnÉs Vicente, J.M. y PiCAZO Millán, J.V. 2005: El proceso de implantación y desarrollo de las comunidades agrarias en el valle medio del Ebro. Monografías Arqueológicas 40. Universidad de Zaragoza.

—, 2009: «La Cabaña Mesolítica del Cabezo de la Cruz (La Muela, Zaragoza)». En Utrilla, P. y Montes, L. (eds.): El Mesolítico Geométrico en la Península Ibérica, Monografías Arqueológicas 44. Universidad de Zaragoza, 327-341.

RodAnés Vicente, J.M., Tilo, M.A. y RAMÓN, N. (coords.) 1996: El abrigo de Els Secans (Maza- león, Teruel). La ocupación del valle del Matarraña durante el Epipaleolítico y Neolítico Antiguo. Al-Qannis, 6. Taller de Arqueología de Alcañiz.

ROYO GUILlÉN, J.I. y GÓMEZ LECUMBERRI, F. 1992: «Riols I: Un asentamiento al aire libre en la confluencia de los ríos Segre y Ebro». En Utrilla, P. (coord.); Aragón/Litoral Mediterráneo. Intercambios culturales durante la Prehistoria. Institución Fernando el Católico, Zaragoza, 297-308.

Rozoy, J.G. 1978: Les Derniers Chasseurs. Bulletin de la Société archéologique Champenoise. 3 t.

SOPENA ViCIÉN, M. ${ }^{\text {a }}$ C. 1992: La comarca de Monzón en la Prehistoria, Tolous n. ${ }^{\circ} 4$, revista del CEHIMO. Monzón.

Stuiver, M. y ReIMER, P.J. 1993: «Extended ${ }^{14} \mathrm{C}$ database and revised CALIB radiocarbon calibration program». Radiocarbon, 35: 215-230.

TOrRegrosA, P., Jover, F.J. y LÓPEz SEGuí, E. (dirs.): Benàmer (Muro d'Alcoi, Alicante). Mesolíticos y Neolíticos en las tierras meridionales valencianas. SIP, trabajos varios 112 .

UTriLla, P. 1997: «Del Paleolítico al Epipaleolítico». Crónica del Aragón Antiguo. De la Prehistoria a la Alta Edad Media (1987-1993). Caesaraugusta, 72 (1): 15-57.

—, 2001: «Paleolítico y Epipaleolítico en Aragón. De 1993 a 1998». Caesaraugusta, 75: 115-158.

—, 2002: «Epipaleolíticos y Neolíticos en el valle del Ebro». Saguntum Extra 5. (The Neolithic Landscapes of the Mediterranean): 179-208.

Utrilla, P., Cava, A., Alday, A., Baldellou, V., Barandiarán, I., Mazo, C. y Montes, L. 1998: «Le passage du Mésolithique au Néolithique Ancien dans le Bassin de l'Ebre (Espagne) d'après les datations C 14». Préhistoire Européenne, 12: 171-194.

UTRILlA, P., y DOMINGO, R. 2002: «Informe de la Campaña del 2000 en el abrigo de Ángel o Arenal de Fonseca». Saldvie, 2: 337-353.

Utrilla, P., Domingo, R. y Martínez BeA, M. 2003: «La campaña de 2002 en el Arenal de Fonseca (Ladruñán, Teruel)». Saldvie, 3: 301-311.

UTRILla, P. y GIMENO, J.M. a 1981: «Yacimientos líticos de superficie de la cuenca del Jalón». $P a$ peles Bilbilitanos, 3: 7-22.

UTRILlA, P. y MAZO, C. 1997: «La transición del Tardiglaciar al Holoceno en el Alto Aragón: los abrigos de las Forcas (Graus, Huesca)». II Congreso de Arqueología Peninsular, I: 349-365. Zamora. 
Utrilla, P. y Mazo, C. 2007: «La Peña de Las Forcas de Graus (Huesca). Un asentamiento reiterado desde el Magdaleniense Inferior al Neolítico Antiguo». Saldvie, 7: 9-38.

Utrilla, P. y Montes, L. (eds.) 2009: El Mesolítico Geométrico en la Península Ibérica. Monografías Arqueológicas 44. Universidad de Zaragoza.

UTRILlA, P. y RoDANÉS, J.M. (eds.) 2004: Un asentamiento epipaleolítico en el valle del río Martín. El abrigo de los Baños (Ariño, Teruel). Monografías Arqueológicas 39. Zaragoza.

Utrilla, P., Montes, L., Mazo, C., Martínez BEA, M. y Domingo, R. 2009: «El Mesolítico geométrico en Aragón». En Utrilla, P. y Montes, L. (eds.): El Mesolítico Geométrico en la Península Ibérica. Monografías Arqueológicas 44, 131 190.

VAlero-Garcés, B., GonzÁlez, P., NAVAS, J.M., Machín, J., Delgado, A., PeÑA, J.L., SANCHO, J.L., STEVENSON, A. y DAVIS, B. 2004: «Palaeohydrological fluctuations and steppe vegeta- tion at the last Glacial Maximun in the Central Ebro valley (NE Spain)». Quaternary International, 122: 43-55.

VAlero-Garcés, B., GonzÁlez-SAMPÉRIZ, P., Delgado-Huertas, A., NAVAS, A., MAChÍN, J. y KELTS, K. 2000: «Late glacial and Late Holocene environmental and vegetational change in Salada Mediana, central Ebro basin, Spain». Quaternary International, 73-74: 29-46.

VALLESPí, E. 1959a: Bases arqueológicas para el estudio de los talleres de sílex del Bajo Aragón. Tesis doctoral inédita. Universidad de Zaragoza.

—, 1959b: «Bases arqueológicas para el estudio de los talleres de sílex del Bajo Aragón. Hacia una seriación de las industrias líticas postpaleolíticas bajoaragonesas». Caesaraugusta, PSANA, 13-14: $7-21$.

WENINGER, B. y JÖRIS, O. 2004: Glacial Radiocarbon Calibration. The CalPal Program. En Higham, T., Bronk, C. y Owen, R.C. (eds.): Radiocarbon and Archaeology. Fourth International Symposium. Oxford. 2002. 

Monografías Arqueológicas / Prehistoria / 45
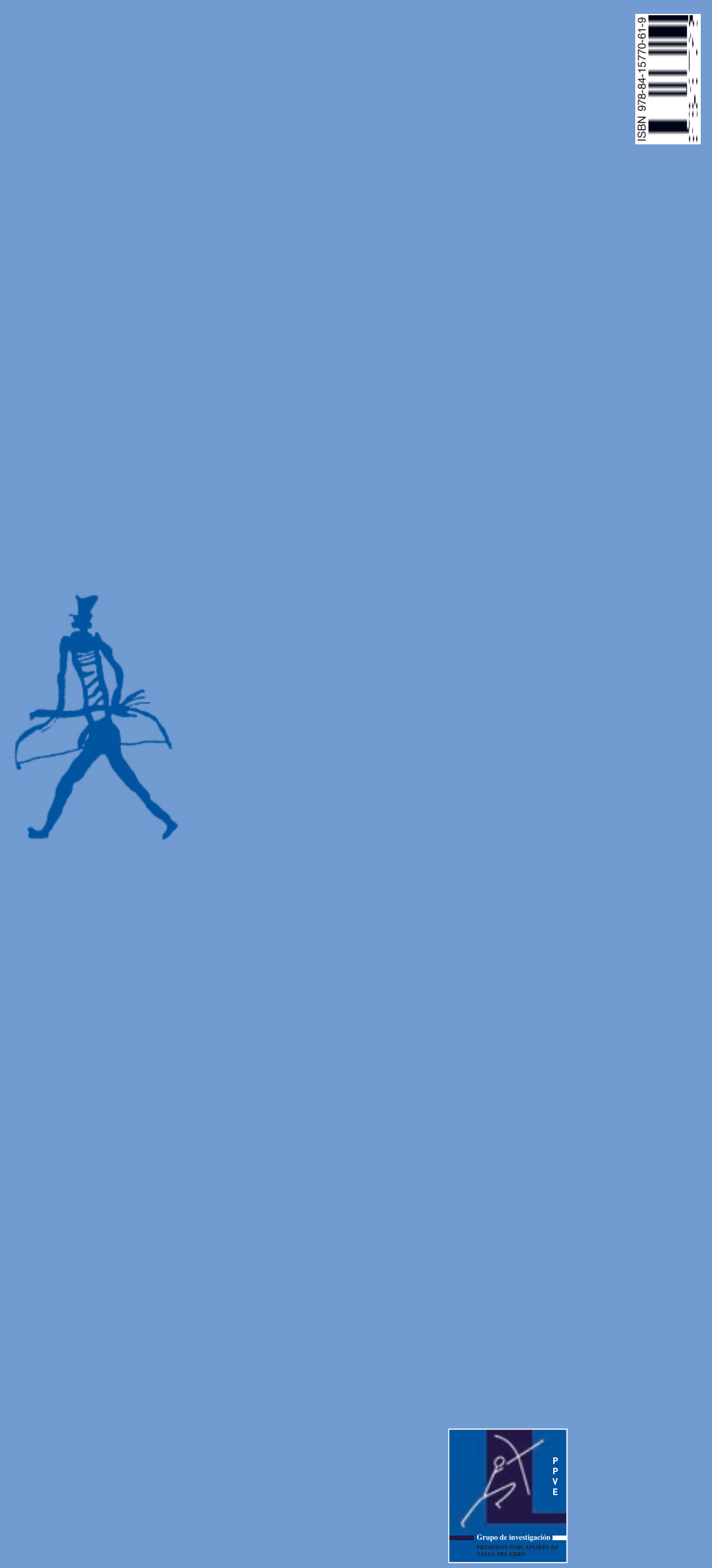